\title{
A QUESTÃo EPIDEMIOLÓGICA E A CAPACIDADE DE RESPOSTA DOS SERVIÇOS DE SAÚDE BUCAL NO BRASIL
}
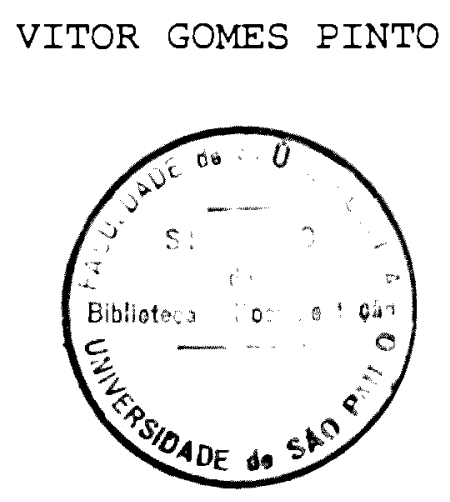

TESE APRESENTADA À FACULDADE DE SAÚDE PÚBLICA DA UNIVERSIDADE DE SÃO PAULO PARA OBTENÇÃO DO TITULO DE DOUTOR EM SAÚDE PÚBLICA.

Orientadora: Prof ${ }^{9}$ Yvette Viegas 
FICHA CATALOGRÁFICA

PINTO, Vitor Gomes.- a questão epidemiológica e a capacidade de resposta dos serviços de saúde bucal no Brasil. Brasilia,1992. 217+XXXVp.

Tese (Doutoramento) Faculdade de Saúde pública. Universidade de são Paulo.

1. Odontologia - Financiamento 2. Serviços de Saúde 3. Epidemiologia - Indicadores de Saúde Bucal. 
A Alfredo Reis Viegas, que muita falta está fazendo a todos nós

AO IPEA, onde se passaram dezessete anos, pelos conhecimentos, experiências e amizades 
AGRADECIMENTOS

SINOPSE

$S$ U M M A R Y

1. INTRODUÇÃO

2. OBJETIVOS 3

3. METODOLOGIA GERAI 3

4. POPULAÇÃO, DESENVOLVIMENTO ECONÔMICO E SISTEMA DE SAÚDE

4.1. Caracterização Demográfica

4.2. Condições Recentes de Desenvolvimento Nacional As Crises da Década de Oitenta 15

4.2.1. A Mudança Política 15

4.2.2. A Crise Econômica 16

4.2.3. Comparações Internacionais a
década perdida

4.3. O Sistema de Atenção à Saúde : 25

4.3.1. Condições de Saúde da População 25

4.3.2. Oferta e Consumo de Serviços Públicos 30

4.3.3. Evolução do Sistema 35

4.3.4. Financiamento da Saúde na
Seguridade Social

4.3.5. A Crise Setorial 41

5. O APARELHO PRESTADOR DE SERVIÇOS ODONTOLÓGICOS 44

5.1. Oferta de Profissionais no País 45

5.2. Postos de Trabalho e Recursos Humanos
no Setor Público

5.2.1. Serviços da Previdência Social 53

5.2.2. Postos de Trabalho Ocupados em
Odontologia 
5.2.3. Recursos Humanos de Nível Técnico e Auxiliar

5.3. Capacidade Instalada do Setor Público

6. GASTOS COM SAÚdE

6.1. Gastos Pessoais em Saúde Geral

6.2. Gastos Pessoais com Atenção Odontológica

6.3. Gastos Institucionais e Totais em Saúde Bucal

6.4. Análise Conjunta

7. A QUESTÃO EPIDEMIOLÓGICA

7.1. O Levantamento Epidemiológico Nacional

7.1.1. Sintese

7.1.2. Pontos a Equacionar

7.2. Estimativas por Idade e Renda

Abrangência e Metodologia Específica

7.2.1. Abrangência

7.2.2. Modelo de Análise Estatistica

7.2.3. Dentição por Idade

7.2.4. Médias por Idade e Renda

7.3. Indicadores Positivos de Saúde Bucal

7.4. Ataque de Cárie na População de 5 a 79 Anos

7.5. Procura de Atendimento

7.6. Necessidade e Uso de Próteses Totais

7.7. Edentulismo

7.8. Condições de Saúde Periodontal

7.8.1. População Sadia e Com Problemas Periodontais

7.8.2. CPITN da Amostra Populacional 
8. PROGRAMAS E POLÍTICAS DE SAÚDE BUCAI

8.1. O Nível Central

Avanços e Retrocessos

8.2. A Prevencão da Cárie Dental no Brasil

8.2.1. Fluoretação da Água de Consumo Público

8.2.2. Fluoretação do Sal de Cozinha

8.2.3. Bochechos com Fluoreto de Sódio

8.2.4. Aplicações Tópicas com Fluoretos

8.2.5. Selantes Oclusais

8.2.6. Terapia Intensiva

8.2.7. Dentifrícios Fluoretados

8.3. Programas Estaduais e Municipais

8.4. Temas Relacionados

8.4.1. Consumo e Produção de Açúcar

8.4.2. Sistema de Ensino Elementar

8.5. Compatibilidade entre o Sistema

Prestador de Serviços e os Quadros

Epidemiológico e Social

9. RESPOSTAS DO SISTEMA PRESTADOR DE SERVIÇOS

SUGESTÕES

9.1. Sistema Geral de Atendimento

9.1.1. A Organização Local

9.1.2. Adscrição da Clientela

9.1.3. Participação Social

9.2. Serviços Essenciais e Complementares

9.2.1. Ações Preventivas

9.2.2. Educação em Saúde Bucal

9.2.3. Atenção a Crianças e a Adolescentes 
9.2.4. Atenção a Outros Grupos e Problemas

9.2.5. Vigilância Sanitária

9.2.6. Vigilância Epidemiológica

9.3. Politica de Recursos Humanos

9.4. Custeio e Remuneração dos Serviços

9.5. Iinhas de Estudo e Pesquisa

9.5.1. Estudos sobre Fatores Etiológicos

9.5.2. Estudos Epidemiológicos

9.5.3. Estudos sobre o Sistema Prestador de Serviços

9.5.4. Estudos sobre Prevenção

9.5.5. Educação em Saúde e Opiniões da População

9.6. Sintese e Sugestões 


\section{AGRADECIMENTOS}

Somente com o apoio fraterno e amigo dos que nos cercam é possivel construir e levar avante un trabalho deste porte.

Agradecer a todos certamente não é una missão das mais fáceis. Mesmo correndo o risco de não mencionar alguém, desejo expressar uma imensa gratidão a todos os que doaram uma parte de si e tiveram um papel fundamental nas diversas fases de elaboração da tese.

Geraldo da Silva e Souza encontrou tempo, entre suas intensas atividades como professor titular de estatistica da UNB e pesquisador da EMBRAPA, para desenhar o modelo de análise que permitiu concretizar as estimativas sobre a situação epidemiológica.

No IPEA muitos ajudaram. Maria Emilia Barbosa da Veiga estruturou passo a passo as referências bibliográficas. Nos computadores tive ao meu lado José Adalberto de Paula Ferreira e Iuis Carlos dos Santos. A organização final das tabelas e do texto, deixando-os prontos para a impressão, foi feita por Aeromilson Trajano de Mesquita, com o atento acompanhamento de Hercules Abrão de Ará́jo. Quando foi preciso trabalhar com o "SAS", lá estavam Carlos Henrique Motta Coelho e Moyses Tenenblat. As projeções de população, a identificação dos indicadores econômicos e demográficos e muito apoio estatístico vieram principalmente de Sebastiāo Francisco Camargo. O modelo para a proposta de vigilância epidemiológica foi elaborado com apuro por Alfonso Arias. José Hamilton Bizarria, mestre de macro-economia, esteve sempre presente quando o desenvolvimento e as crises típicas do desenvolvimento brasileiro entraram na pauta de trabalho. Divonzir Arthur Gusso, na coordenação das atividades de educação, fundamentou as análises sobre o sistema de ensino elementar. Antonio Carlos Xavier deu sugestões muito úteis na interpretação dos liames estatísticos. Da direção de casa, desde o início, não faltou apoio, principalmente da parte de Luiz Carlos Eichenberg da Silva, Liscio Fabio de Brasil Camargo, Emilio Sendim Marques, Sergio Francisco Piola.

No MEC contei com a atenção e a capacidade cientifica de Liliane de oliveira e de J.Montenegro.

Antonio Galvão Fortuna Rosa inscreveu-me no curso de doutorado e depois ficou atento ajudando-me a caminhar pelos corredores da Faculdade de Saúde pública, quase sempre na companhia solidária de Roberto Augusto Castellanos Fernandez.

Em casa, Ilza, Rodrigo Pedroso e Gracielinha estiveram comigo em cada momento, tornando-se parte da tese com seu estímulo e carinho.

Muito mais do que a orientadora de todo o trabalho, tive na Professora Yvette Viegas uma amiga que me deu, junto aos ensinamentos técnicos, Iições de crença na vida e de dignidade que se fizeram inesquecíveis e permanentes. Muitas vezes foi a sua força de vontade e o seu exemplo de Sanitarista que permitiram avançar e, afinal, chegar ao porto de destino no tempo previsto. 


\section{SINOPSE}

- texto dedica-se, inicialmente, ao estudo das condições de desenvolvimento brasileiro nas áreas econômica e social, retratando a forte crise que caracterizou os anos oitenta. Após examinar o sistema geral de atenção à saúde, analisa o aparelho prestador de serviços odontológicos e os gastos em saúde geral e em saúde bucal para o ano de 1989 .

A questão epidemiológica é vista sob a ótica de cinco indicadores principais: ataque pela cárie dental, doenças periodontais, necessidade e uso de próteses totais, edentulismo e procura de atendimento, estimando-se médias, percentuais e valores totais idade por idade para a população de 5 a 79 anos. 0 estudo dos programas e politicas setoriais engloba as iniciativas de nível central e regional, as ações preventivas e dois temas relacionados à saúde oral: o consumo e produção de açúcar e o modelo de ensino elementar.

Apresentam-se sugestōes para estruturação geral do sistema de atendimento odontológico com ênfáse em sub-sistemas de prevenção, educação em saúde, atenção a crianças e adolescentes, cuidados a outros grupos e problemas, vigilância sanitária e epidemiológica, além de propor medidas relacionadas à preparação de recursos humanos, ao financiamento setorial e às linhas de estudos e pesquisas.

\section{S U M M A R Y}

First of all the text looks at the Brazilian economic and social development showing the strong general crisis of the last decade. After reviewing the global health system, it examines the dental care system and the financial aspects and expenditures of the health and dental sectors for 1989.

The epidemiological question is focused on the basis of five main indicators: dental caries attack, periodontal diseases, needs and use of dentures, edentulism and demand for dental care, including statistical estimations related to averages, percentages and total needs for urban people 5 to 79 year-old. The analysis of the oral health programs and policies includes central and regional actions, preventive measures, sugar consumption and production, and the elementary education model.

Suggestions are presented for the following topics: structure of the dental care system for the Brazilian population with emphasis on sub-systems of prevention; health education; dental care for children, youths and other age brackets; sanitary and epidemiological monitoring programs; dental personnel training; financing and, finally, research recommendations. 


\section{INTRODUÇĀo}

Há uma clara interdependência entre os problemas que afetam uma área especifica como a saúde bucal e os que caracterizam 0 conjunto da sociedade. As análises que constituem o cerne deste trabalho procuram seguir este princípio, evitando o tratamento do diagnóstico e das soluções das grandes questões odontológicas como um oásis particular dentro de um país com tantas desigualdades e carências como é o Brasil.

A década iniciada em 1980 caracterizou-se por uma aguda crise econômica que pouco a pouco afetou cada parcela da população. Paradoxalmente, por vezes setores como a saúde e a educaçāo podem beneficiar-se crescendo nesses períodos de dificuldades globais, pois são tidos como núcleos típicos de políticas sociais compensatórias. Ou seja, as dificuldades de ordem principalmente financeira procuram ser atenuadas por um maior investimento e apoio às áreas sociais.

Os estudos sobre o desenvolvimento brasileiro recente indicam, no entanto, que isto não ocorreu. O país chegou a ser classificado, junto com a Nigéria e o Paquistão, no grupo da "década das oportunidades perdidas", pois embora tenham sido aplicados recursos razoáveis nas atividades sociais, estes em boa parte não chegaram aos seus reais destinatários - as comunidades de menor renda possivelmente se perdendo nos intricados liames da estrutura intermediária encarregada de implementar os programas governamentais.

- setor saúde, que acumulara pendências não resolvidas nas décadas anteriores, tentou reestruturar-se em meio à crise. Embora - sistema nacional de saúde tenha passado por uma substancial mudança com a aprovação do Sistema Único de Saúde, houve uma pronunciada deterioração dos serviços de atendimento ambulatorial e hospitalar principalmente nas cidades de médio e grande porte.

Como um artefato de efeito tardio, a crise explodiu no setor saúde com maior força no final do decênio, aprofundando-se ao ponto de que por mais de uma vez as pesquisas de opinião popular detectaram-no como o problema número um sentido pelas pessoas, superando até mesmo focos tradicionais de tristezas e de desesperanças como 0 são as dificuldades monetárias e as questões ligadas à marginalidade urbana. Em consequência, as propostas de solução via privatização dos serviços de saúde começaram a ganhar cada vez mais espaço, traduzindo-se em uma notória expansão das empresas que se dedicam a este ramo de comércio e em uma maior agressividade na divulgação de suas propostas.

Paralelamente, as unidades públicas passaram a perder substância apresentando-se aos olhos de seus pacientes cada vez mais como serviços destinados ao uso apenas daqueles que não conseguem acesso a qualquer outro tipo de atenção médica ou odontológica. Observando todo este evoluir do instável equilíbrio 
interno do setor, largas camadas da população, de baixa renda, permaneceram inteiramente dependentes dos serviços públicos, esperando pela sua melhora.

Considerada como uma profissão de exercício individual el privado, a odontologia ao longo dos anos oitenta continuou atraindo um elevado número de novos adeptos, vendo-se afinal envolvida na crise geral quando a essência de seu modelo de ação - liberal por excelência - passou a ser contestado.

Habituada ao entendimento direto com 0 paciente $e$ aos programas de saúde pública para pequenas comunidades, em geral de escolares, a profissão descobriu que esse tipo de prática não conseguiu melhorar ou sequer manter estáveis os níveis de saúde bucal dos brasileiros. Ao contrário, o país tornou-se um exemplo negativo, liderando as estatísticas internacionais quanto aos indices de ataque pela cárie dental em crianças e adolescentes, não obstante o fato de que a oferta de profissionais de nível superior tenha aumentado ao ponto de representar cerca de $11 \%$ da mão-de-obra odontológica disponível no mundo.

A hipótese que norteia este trabalho é de que um exame mais detido dessa complexa realidade, combinando conhecimentos sobre a epidemiologia das doenças bucais e sobre a oferta de serviços clínicos e preventivos com informaçōes gerais sobre os padrōes de desenvolvimento social e econômico da nação, possa resultar na identificação de soluções melhores ou mais oportunas para o extenso volume de problemas hoje existente.

São escassos os estudos de abrangência nacional no campo da odontologia de saúde pública e de seu relacionamento com os aspectos econômicos e sociais e com as realidades mais abrangentes do setor saúde em geral. o levantamento epidemiológico em saúde bucal realizado pelo Ministério da Saúde(34), relativo à prevalência dos principais problemas da cavidade oral junto à população urbana do país, constitui uma exceção à regra geral. Mas, apenas dados globais chegaram a ser publicados, referindo-se aos números diretamente encontrados no exame da amostra populacional examinada. Um importante e vasto universo de dados permanece inexplorado e ser. qualquer tratamento estatístico que permita inferir seus resultados para outros grupos etários que não os examinados e para o conjunto da população urbana.

A obtençăo de um quadro epidemiológico bem mais preciso e mais universal só tem significado prático se puder ser comparado com as politicas vigentes e com a oferta existente de serviços clínicos, educativos e preventivos, a fim de encontrar os caminhos e as soluçōes que mais chances tenham de responder aos desafios dos tempos atuais. 


\section{OBJETIVOS}

\section{- Objetivo Geral}

Contribuir para a compreensão das causas e dos efeitos dos principais problemas de saúde bucal da população brasileira, relacionando-os com os padrōes de desenvolvimento do pais e apontando medidas para sua solução.

\section{- Objetivos Especificos}

a) - Construir um quadro epidemiológico global para a população de 5 anos e mais residente em zona urbana no Brasil, incluindo uma estratificaçāo dos dados por estrato de renda familiar;

b) - dimensionar a oferta de serviços e estabelecer a compatibilidade ou não entre o sistema de prestação de cuidados à população, as condições sócio-econômicas e epidemiológicas vigentes;

c) - apresentar proposições alternativas para dar melhor solução aos problemas constatados.

\section{METODOLOGIA GERAL}

A Iinha de estruturação do documento aqui descrita não envolve aspectos metodológicos muito específicos ou muito técnicos (sobre a composição de uma tabela ou sobre programas de computação eletrônica por exemplo), os quais são tratados no próprio capitulo a que se referem ou são descritos em anexos.

A partir do Capítulo 4, o trabalho está dividido em seis grandes títulos sequenciais, abordando nos cinco primeiros os assuntos substantivos e no último apresentando as sugestōes e conclusões gerais. Pela ordem temos: caracterização geral da população e do sistema de saúde, o aparelho prestador de serviços odontológicos, os gastos em saúde, a questão epidemiológica, os programas de atenção odontológica e as respostas possíveis por parte do sistema de prestação de serviços.

- Capítulo 4 concentra as análises que podem ser consideradas como não odontológicas no sentido estrito. Inicialmente consta uma caracterização demográfica para 0 ano de 1989, escolhido como referência para os dados devido a ser o período mais próximo para 0 qual existem informações disponiveis principalmente no que se refere à oferta de serviços e de recursos humanos. Foram utilizadas projeçōes elaboradas pelo IPEA com base nos dados regularmente fornecidos pelo IBGE através dos Censos e das Pesquisas Nacionais por Amostras de Domicilio - PNADs. As estimativas incluem a estratificação dos habitantes por idade, por regiāo e por zona 
urbana e rural, com ênfase nas cidades porque os dados epidemiológicos não englobam os camponeses. Há una evidente dificuldade em trabalhar com projeçōes num ano de final de década, quase às vésperas do censo populacional que forçosamente irá corrigi-las. Na verdade, segundo 0 que se sabe através dos primeiros e preliminares dados do censo de 1991, parece haver uma leve super-estimação no contingente demográfico nacional aqui apresentado tendo em vista que as taxas de crescimento mostraram-se algo inferiores ao esperado. A alternativa seria esperar pelos resultados do censo, mas isto significaria atrazar em quase um ano a elaboração final e apresentação da tese.

As mudanças políticas da década, o desenvolvimento da crise econômica e a comparação com a situação internacional estão no Título 4.2, construido com base na leitura e interpretação de três tipos de publicações: análises situacionais e históricas sobre o que se passou no Brasil a nível de politicas globais e macroeconômicas; estatísticas comparadas sobre o período 1980-89 e, finalmente, estudos elaborados por instituições e autores internacionais.

No Título 4.3 o exame do sistema de saúde vigente no país é feito em cinco tópicos: (a) estudo das condições de saúde da população, a partir de dados de mortalidade e morbidade fornecidos pelos Ministérios setoriais (de Saúde e de previdência e Assistência Social), pelo IBGE ou por pesquisadores da área, destacando-se as contradições nacionais; (b) a oferta e o consumo de serviços públicos, tratando da evolução na década, p.ex., do número de consultas médicas e de hospitalizaçōes custeadas pelo INAMPS com base em dados da DATAPREV e de críticas de estudiosos desse tema; (c) evolução do sistema, referindo-se centralmente à história dos diversos programas na década e à instituição do Sistema Único de Saúde-SUS. Utilizou-se como base de estudo os textos dos programas experimentados nos últimos anos como o PIASS e - PREV-SAÚDE, OS decretos, regulamentos e leis mais atuais sobre o SUS e textos de autores contemporâneos, acrescentando uma visão crítica fundada na vivência junto a boa parte desses programas e projetos; (d) financiamento da saúde na seguridade social, examinando a estrutura de gastos e as regras de apropriação e de repasse dos recursos públicos com ênfase nas relações entre o governo federal e as instâncias estadual e municipal. o referencial teórico e os dados básicos provém das normas e regulamentaçōes do atual Ministério da Saúde/INAMPS, informes financeiros da DATAPREV, orçamentos setoriais e artigos de especialistas; (e) análise da crise que se abateu sobre 0 setor saúde principalmente no 10. semestre de 1990 e que na realidade se estende até os dias atuais, agravada pela escassez de recursos e pela debilidade das soluçōes tentadas neste intervalo. Na falta de textos técnicos, lançou-se mão do vasto noticiário de alguns dos jornais de maior circulação nacional, da época.

- quinto capitulo refere-se ao aparelho de prestação de serviços de saúde bucal. Primeiramente é enfocada a oferta de profissionais no pais, com base em informaçōes fornecidas pelo Conselho Federal de Odontologia (complementadas, p.ex., por dados 
do Conselho Regional de São Paulo) e pelo Ministério da Educação, incluindo comparações com a situação de outros países através da utilização de publicaçōes específicas da Federação Dentária Internacional. Um aspecto metodológico significativo neste campo diz respeito ao número de odontólogos em efetivo exercício. As estatisticas dos Conselhos de classe referem-se aos profissionais inscritos e não necessariamente aos ativos. Embora dados estatisticos precisos não estejam disponiveis, sugere-se no texto com base em discussōes técnicas com especialistas da área - que em torno de 158 dos profissionais inscritos não são ativos, incluindo uma coluna a respeito na tabela que discrimina a quantidade de Cirurgiões-Dentistas por estado. Na verdade, o percentual de inatividade pode ser melhor compreendido se for ligado ao tempo total de trabalho e não exatamente ao número de profissionais, pois muitos exercem a odontologia apenas durante meio turno.

No Tópico 5.2, em uma série de tabelas, procura-se identificar - número de postos de trabalho ocupados por Cirurgióes-Dentistas em instituições públicas e para-oficiais. Os critérios metodológicos utilizados estão especificados no próprio capítulo e no Anexo I. A maior parte das informaçōes originais são provenientes de estudos desenvolvidos em 1989 pela Divisão Nacional de Saúde Bucal do Ministério da Saúde e pela Coordenadoria de Supervisão e Auditoria de Odontologia do INAMPS, diretamente junto aos estados. Esta é também a principal origem dos dados sobre a capacidade instalada em termos de equipamentos odontológicos nas clínicas das entidades oficiais e para-oficiais em 1989.

- Capítulo 6 trata dos gastos em saúde oral, englobando os dispêndios estimados tanto na área privada quanto por parte da área institucional. Os critérios metodológicos são bastante específicos e ligados à estrutura das tabelas que acompanham o texto, estando explicitados nos Anexos II e III.

- quadro epidemiológico compõe o Capítulo 7 e se fundamenta no Levantamento realizado pelo Ministério da Saúde na população urbana de 6 a 12,15 a 19,35 a 44 e 50 a 59 anos de idade. São feitas estimativas idade por idade dos 5 aos 79 anos de idade para 0 conjunto do país, aplicando-se os índices obtidos à população para 1989 com duas finalidades: uma, de estimar os índices por grupos quinquenais de idade ( 5 a 9,10 a 14 , etc.) e, outra, de estimar 0 volume de necessidades ou de tratamentos realizados para o total de habitantes urbanos. Os critérios metodológicos estão todos descritos no texto, mas vale referir que embora o estudo do Ministério da Saúde tenha representatividade regional (seus resultados foram publicados para o total e para cada uma das cinco grandes regiōes), 0 presente trabalho limita-se a formular projeções a nível nacional tanto por questōes operacionais ligadas à extensão e ao volume de dados que significaria acrescentar cinco sub-divisões para cada índice, quanto pela virtual impossibilidade em identificar de maneira ainda mais precisa os programas desenvolvidos nos estados e municípios a fim de relacionar nível de saúde e oferta de serviços, regiāo por região. 
No capítulo 8 são analisados os programas desenvolvidos e em desenvolvimento a nível governamental. A ênfase cabe às açōes veiculadas no âmbito federal devido à disponibilidade de informações. Uma análise estado por estado e ainda do que tem sido feito nos municípios de maior porte, exigiria estudos locais, gastos e disponibilidade de tempo adicionais. Ainda assim, tornouse possível incluir três tópicos de fundamental importância: a) estudo, a partir dos documentos oficiais, textos de especialistas do setor e vivências pessoais, das políticas, programas e atividades praticadas a nível central particularmente na década de oitenta e/ou experimentadas atualmente; b) identificação e exame crítico das ações preventivas, método a método, que tem sido implementadas ou para o total da população como é o caso da fluoretação da água de consumo público, ou para grupos específicos como a aplicação de selantes p.ex.. Documentos técnicos, textos de programas e estudos científicos relacionados à eficácia, eficiência e aplicabilidade de cada método constituiram o substrato para este tópico; c) enfoque sobre programas dos estados e municípios que alcançaram maior destaque ou evidência. Aqui as dificuldades crescem devido à escassez de informações, obrigando-nos a tratar o tema de maneira mais genérica que no item anterior, com uma limitação ditada pelo somatório da literatura acessível e das experiências locais melhor conhecidas. Além disso, acrescentou-se uma análise sobre duas questões muito relacionadas com a área de saúde bucal: 0 consumo e produçāo de açúcares, e o sistema de ensino elementar brasileiro.

A reduzida compatibilidade entre 0 sistema prestador de serviços, o quadro epidemiológico e as condições de desenvolvimento a que tem sido submetido o país é discutida no último tópico, utilizando $o$ cabedal de conhecimentos reunidos neste $e$ nos capítulos anteriores.

Finalmente, o Capítulo 9 reune as sugestões relativas à organização de sistemas locais de saúde bucal e ao sistema de atenção à população, englobando a proposta geral para todas as pessoas, a linha de prestação de cuidados ao grupo prioritário do ponto de vista epidemiológico (crianças em idade escolar primária) e $\circ$ equacionamento de outros grupos e problemas prioritários. 0 sub-sistema preventivo e as açōes educativas merecem um bloco específico de sugestões, com as medidas que detém as melhores chances de sucesso a nível comunitário. Em seguida são apresentadas recomendações sobre a concretização de adequados sub-sistemas de vigilância epidemiológica e sanitấria, encerrando com proposições a respeito da preparação de recursos humanos, das modalidades de custeio e remuneração de serviços e das linhas de estudos e pesquisas.integração das ações de saúde bucal no Sistema único de Saúde. 


\section{POPUlaÇÃo, DESENVOLVIMENTO ECONÔMICO E SISTEMA DE SAÚdE}

\section{:4.1. Caracterização Demográfica}

De acordo com estimativas feitas pela área de demografia da Coordenadoria de Política Social do IPEA(127.128), a população brasileira em 1.989 era de 144.144 .704 pessoas, das quais 105.992 .079 ou 73,58 residindo na zona urbana.

Há um risco implícito - que pode ser considerado como inevitável neste momento - em trabalhar com dados populacionais estimados de 1989, ano de final de década, quase ao mesmo tempo em que é realizado o Censo Demográfico nacional que certamente permitirá corrigir eventuais imprecisōes cometidas por quem, agora, trabalha com base nos dados de 1.980 e nos obtidos através das diversas Pesquisas Nacionais por Amostra de Domicílios - PNADs - da Fundação IBGE(4,5,109,110). Lamentavelmente, problemas de liberação de verbas à época oportuna - coincidindo com a chegada do novo governo e, consequentemente, com a implantação de mais um pacote de medidas econômicas envolvendo fortes restriçōes de gastos públicos impediram a realização do Censo em 1.990 como estava previsto. Ao contrário de praticamente todas as demais naçōes, o Brasil adiou o seu Censo para 1.991.

É possivel afirmar que o ritmo de crescimento populacional brasileiro tende à estabilizaçāo, com base em níveis cada vez mais baixos de mortalidade e de fecundidade. De um lado, tem havido um declínio gradual nas taxas de mortalidade ao longo das últimas décadas, com uma maior aceleração do processo a partir dos anos setenta quando começou a ocorrer um ganho mais significativo em termos de expectativa de vida e uma maior redução nos indices de mortalidade infantil. De outro lado, a fecundidade também a partir da década de 70 começou a mostrar um padrão muito forte de diminuição, depois de ter-se mantido virtualmente estável desde 1940 (31).

- Quadro 1 retrata as mudanças acontecidas no Brasil, de 1940 a 1989, em relação a três indicadores básicos: fecundidade, expectativa de vida ao nascer e mortalidade infantil, mostrando que as tendências se mantém por vezes ainda mais pronunciadas, como é 0 caso das duas últimas taxas, na década de oitenta.

Não obstante tenha ocorrido uma melhora relativa global, e apesar de todos os progressos alcançados no campo médico-sanitário, manteve-se uma forte desigualdade social frente às probabilidades de morte, estimando-se que em 1984 um brasileiro pertencente a uma familia com renda superior a cinco salários-mínimos poderia viver em média 16 anos a mais que as provenientes de familias com renda inferior a um salário-mínimo(31). Esta diferença era de 608 em relação à taxa de mortalidade infantil.

o declínio da fertilidade, porém, aconteceu em todas as regiōes e em todas as classes sociais, possivelmente como uma consequência das transformaçōes por que vem passando a sociedade 
que tem conduzido, entre outros fatores, a um forte aumento no uso de métodos anticoncepcionais.

Os dados mostrados no Quadro escondem fortes diferenças regionais. Em 1984, p.ex., a Taxa de Fecundidadetotal era de 4,60 no Nordeste e de 2,70 no Sudeste, enquanto a Mortalidade Infantill por 1000 nascidos vivos era de 130,3 em Fortaleza e 80,1 em Recife, em comparação com 56,6 em Belo Horizonte, 49 no Rio de Janeiro e 36,9 em Porto Alegre. a expectativa de vida ao nascer em 1980 variava desde 67,2 anos no sul até 51,0 no Nordeste $(5,10,31)$

A Taxa Geométrica de Crescimento Populacional apresentou un descenço relativo pouco superior a $15 \%$ entre as décadas de setenta $(2,48)$ e de sessenta $(2,93)$. As estimativas do Banco Mundial(7), que são otimistas em relação às projeções adotadas a nível nacional (127.128), referem un crescimento médio anual de 2,28 entre 1980 e 1989, prevendo que chegará a 1,7 \& entre 1989 e 2000 . Os primeiros resultados do Censo de 1991 já indicam que essas taxas são ainda menores (em torno de 1,898 no período 80-91).

Quanto à distribuição regional da população, vemos pelo Gráfico I que seis em cada dez brasileiros vivem nas regiões sul e sudeste, mais desenvolvidas economicamente. Os Gráficos II e III mostram que a região sudeste é a maior responsável pela urbanização crescente que tem caracterizado o processo migratório interno: 538 da população urbana reside em São Paulo, Rio de Janeiro, Espirito Santo e Minas Gerais, ao passo que somente $20 \%$ do contingente rural ai se localiza.

Os dados constantes das Tabelas 1 a 3 constituem a base para as estimativas e previsōes populacionais feitas no Capítulo 7.

A Tabela 1 fornece a população total, urbana e rural por regiōes e por grupos quinquenais de idade. Em seguida, a Tabela 2 discrimina uma a uma as idades de 5 a 14 anos, também com estratificação pelo local de domicílio. Por último, a Tabela 3 apresenta dados idade por idade da população urbana, de 5 a 69 anos, para cada uma das cinco regiōes e para o país como um todo.

Períodos variados de "booms" de nascimentos, associados com fluxos regionais de migração mais intensa provocam variações interessantes nos dados de alguns grupos etários. É o caso, por exemplo, da região Sudeste, na qual o contingente populacional dos grupos de 5-9, 10-14, 20-24 e 25-29 anos supera em número aos seus grupos etários precedentes. Fenômeno similar se dá nas regiōes sul e Centro-Oeste para a faixa de 10-14 anos. Mesmo para o Brasil algumas idades (Tab. 1) suplantam as anteriores em estoque populacional.

Para efeitos de definição de politicas de saúde bucal seja nas áreas de prevenção e educação seja no campo clínico, é a grandeza dos números que mais impressiona, ou seja, o grande volume populacional brasileiro que necessita cuidados de saúde. Apenas na zona urbana são 11,5 milhōes de pessoas entre 0 e 4 anos; 11,1 entre 5 e 9; 11,5 entre 10 e 14 e 10,7 milhöes entre 15 e 19 anos 
para citar somente aqueles costumeiramente considerados como os mais prioritários do ponto de vista odontológico. 
QUADRO 1

TAXA DE FECUNDIDADE, EXPECTATIVA DE VIDA AO NASCER E MORTALIDADE INFANTIL POR MIL NASCIDOS VIVOS BRASIL, 1940 A 1989

\begin{tabular}{l|r|r|r|r|r|r|r}
\hline \multirow{2}{*}{ INDICADORES } & \multicolumn{1}{|c}{ A NOS } \\
\cline { 2 - 7 } & 1940 & 1950 & 1960 & 1970 & 1980 & 1984 & 1989 \\
\hline & & & & & & & \\
TAXA FECUNDIDADE & 6,16 & 6,21 & 6,28 & 5,76 & 4,35 & 3,53 & 3,30 \\
EXP.VIDA AO NASCER & 41,53 & 45,51 & 51,64 & 53,46 & 60,08 & 65,28 & 66,00 \\
MORT.INFANTIL & 163,59 & 146,37 & 121,08 & 113,79 & 88,00 & 68,14 & 59,00 \\
\hline
\end{tabular}

Fontes: Bibliografias 7,31 
GRÁFICO I
DISTRIBUIÇÃO DA POPULAÇÃO BRASILEIRA POR REGIÃO

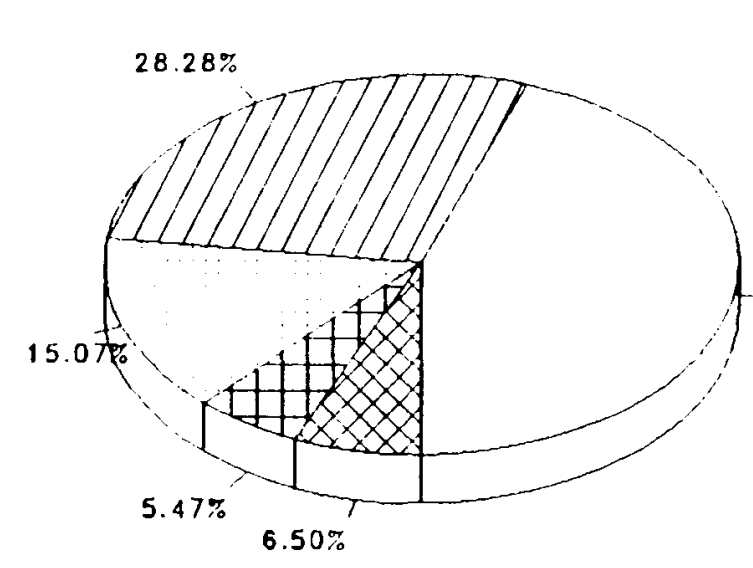

TOTAL

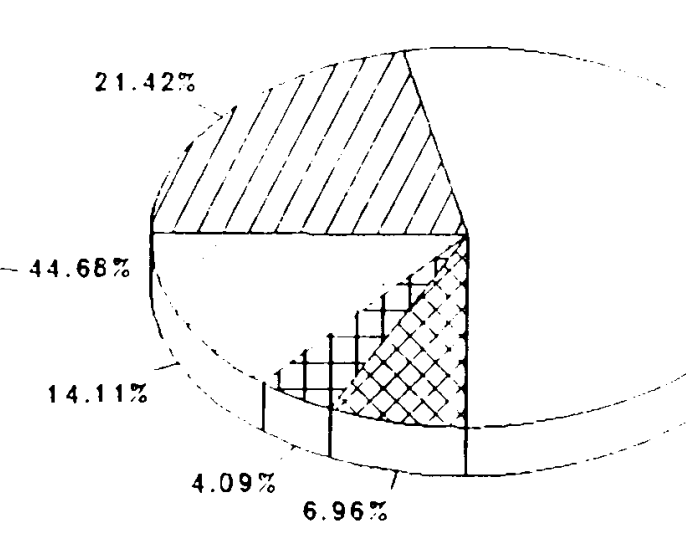

URBANA

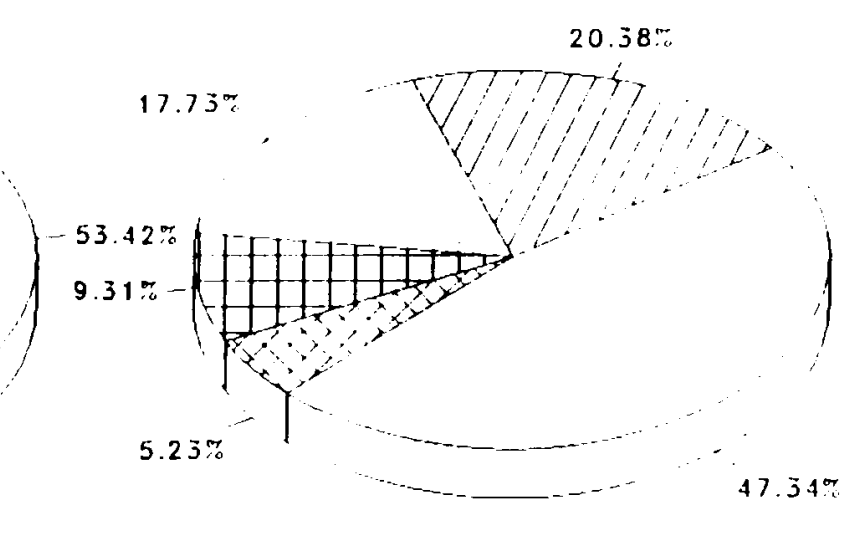

RURAL 
TABELA 1

ESTIMATIVAS DA POPULAÇÃO POR GRANDES REGIÓES, SEGUNDO O DOMICILIO. 1889.

\begin{tabular}{|c|c|c|c|c|c|c|}
\hline \multirow[b]{2}{*}{ IDADES } & \multirow[b]{2}{*}{ BRASIL } & \multicolumn{5}{|c|}{ GRANDES REGIÓES } \\
\hline & & NORTE & NORDESTE & SUDESTE & SUL & $\begin{array}{c}\text { CENTRO } \\
\text { OESTE } \\
\end{array}$ \\
\hline TOTAL & 144.144 .704 & 7.887 .745 & 40.764 .272 & 64.300 .754 & 21.718 .335 & 9.374 .598 \\
\hline $00 \wedge 04$ & 17.281 .503 & 1.180 .474 & 5.983 .549 & 6.657 .384 & 2.308 .202 & 1.121 .814 \\
\hline $05 \wedge 09$ & 16.037 .800 & 1.105 .697 & 5.512 .452 & 6.868 .280 & 2.252 .280 & 1.101 .211 \\
\hline $10 \wedge 14$ & 16.495 .382 & 1.066 .894 & 5.209 .431 & 0.719 .628 & 2.344 .772 & 1.154 .550 \\
\hline $15 A 10$ & 14.003 .131 & 901.680 & 4.626 .528 & 6.149 .283 & 2.197 .880 & 1.027 .752 \\
\hline $20 \wedge 24$ & 14.104 .451 & 764.835 & 4.003 .562 & 6.181 .588 & 2.185 .657 & 958.711 \\
\hline 25 A 20 & 13.118 .812 & 643.804 & 3.223 .581 & 6.283 .064 & 2.093 .258 & 872.117 \\
\hline $30 \wedge 34$ & 10.089 .040 & 523.104 & 2.411 .450 & 5.580 .007 & 1.750 .362 & 723.046 \\
\hline $35 \wedge 30$ & 8.886 .356 & 410.981 & 1.964 .734 & 4.494 .360 & 1.435 .619 & 580.662 \\
\hline $40 \wedge 44$ & 7.175 .074 & 317.554 & 1.000 .543 & 3.543 .378 & 1.182 .814 & 460.787 \\
\hline $45 \wedge 48$ & 5.957 .835 & 262.033 & 1.444 .324 & 2.807 .053 & 962.784 & 381.141 \\
\hline $50 \wedge 54$ & 5.161 .725 & 213.572 & 1.243 .978 & 2.554 .579 & 833.530 & 318.068 \\
\hline $55 \wedge 50$ & 4.145 .064 & 160.258 & 802.337 & 2.108 .283 & 682.650 & 233.538 \\
\hline $60 \wedge 64$ & 3.384 .439 & 123.232 & 816.340 & 1.710 .113 & 551.214 & 174.540 \\
\hline $\begin{array}{c}65 \wedge 60 \\
70 \text { E MAIS }\end{array}$ & $\begin{array}{l}2.338 .580 \\
3.597 .303\end{array}$ & $\begin{array}{r}84.307 \\
118.342\end{array}$ & $\begin{array}{r}514.017 \\
1.157 .448\end{array}$ & $\begin{array}{l}1.217 .004 \\
1.018 .890\end{array}$ & $\begin{array}{l}404.582 \\
542.723\end{array}$ & $\begin{array}{l}118.660 \\
140.894\end{array}$ \\
\hline URBANA & 105.992 .079 & 4.333 .835 & 22.700 .806 & 56.022 .760 & 14.054 .250 & 7.380 .410 \\
\hline $00 \wedge 04$ & 11.494 .851 & 582.811 & 2.940 .131 & 5.573 .457 & 1.554 .588 & 835.164 \\
\hline $05 A 09$ & .325 & 542.748 & 2.667 .022 & 5.570 .012 & 1.510 .072 & 798.471 \\
\hline $10 A 14$ & 11.482 .601 & 567.004 & 2.727 .303 & 5.746 .065 & 1.552 .660 & 888.680 \\
\hline $\begin{array}{l}15 \wedge 10 \\
20 \wedge 24\end{array}$ & $\begin{array}{l}10.700 .155 \\
10.571 .678\end{array}$ & $\begin{array}{l}511.600 \\
453.532\end{array}$ & $\begin{array}{l}2.808 .504 \\
2.405 .713\end{array}$ & $\begin{array}{l}5.313 .883 \\
5.458 .808\end{array}$ & $\begin{array}{l}1.441 .862 \\
1.474 .028\end{array}$ & $\begin{array}{l}824.297 \\
779.597\end{array}$ \\
\hline $25 \wedge 20$ & 10.258 .868 & 388.074 & 2.010 .585 & 5.670 .065 & 1.471 .958 & 710.004 \\
\hline $30 \wedge 34$ & 8.778 .884 & 309.487 & 1.506 .860 & 5.005 .042 & 1.277 .091 & 589.815 \\
\hline $35 \wedge 30$ & 7.072 .378 & 230.783 & 1.202 .437 & 4.004 .462 & 1.057 .804 & 477.730 \\
\hline $40 A 44$ & 5.622 .098 & 182.174 & 1.000 .724 & 3.206 .810 & 844.585 & 378.794 \\
\hline $45 A 49$ & 4.592 .472 & 146.892 & 841.562 & 2.609 .494 & 685.097 & 309.427 \\
\hline $50 \wedge 54$ & 3.978 .040 & 122.579 & 725.049 & 2.290 .705 & 583.482 & 254.225 \\
\hline 55 A 59 & 3.210 .734 & 93.952 & 562.854 & 1.802 .778 & 474.927 & 188.123 \\
\hline $60 A 64$ & 2.820 .417 & 73.108 & 470.818 & 1.547 .158 & 382.342 & 137.890 \\
\hline 65 A 69 & 1.770 .513 & 49.899 & 257.273 & 1.003 .400 & 276.453 & 93.389 \\
\hline 70 E MAIS & 2.756 .171 & 60.503 & 746.781 & 1.454 .522 & 306.541 & 118.824 \\
\hline RURAL & 38.152 .625 & 3.553 .910 & 18.063 .466 & 7.776 .285 & 6.784.078 & 1.004 .188 \\
\hline $00 \wedge 04$ & 5.766 .552 & 607.863 & 3.034 .418 & 1.083 .007 & 753.614 & 286.750 \\
\hline 05 A 09 & & 2.949 & .430 & 1.090 .248 & 208 & 4.740 \\
\hline $10 \mathrm{~A} 14$ & 5.012 .781 & 499.090 & 2.482 .128 & 973.561 & 792.103 & 265.899 \\
\hline $15 A 19$ & 4.202 .976 & 390.071 & 2.018 .022 & 835.410 & 756.018 & 203.455 \\
\hline 20 A 24 & 3.532 .773 & 311.403 & 1.597 .849 & 722.778 & 721.629 & 179.114 \\
\hline 25 A 29 & .146 & 255.820 & 1.213 .016 & 607.890 & 621.298 & 182.113 \\
\hline 30 A 34 & 2.210 .185 & 213.727 & 904.581 & 485.955 & 472.671 & 133.231 \\
\hline $35 \wedge 39$ & 1.813 .980 & 171.188 & 762.297 & 390.808 & 377.655 & 102.932 \\
\hline $40 A 44$ & 1.552 .978 & 135.380 & 680.819 & 338.557 & 318.229 & 81.993 \\
\hline $45 A 49$ & 1.365 .463 & 115.741 & 602.762 & 297.558 & 277.687 & 71.714 \\
\hline $50 \wedge 54$ & 1.185 .685 & 90.093 & 518.929 & 203.874 & 250.048 & 61.841 \\
\hline $55 \wedge 50$ & 034.330 & 60.304 & 300.383 & 213.505 & 207.723 & 47.415 \\
\hline $60 A 64$ & 764.022 & 50.124 & 338.421 & 171.056 & 168.872 & 38.650 \\
\hline $65 A 68$ & 568.067 & 34.408 & 256.744 & 123.505 & 128.139 & 25.271 \\
\hline 70 E MAIS & 831.132 & 48.839 & 410.667 & 164.374 & 176.182 & 31.070 \\
\hline
\end{tabular}

Fonte: Bibliogratia 127 
TABELA 2

POPULACAO DE 5 A 14 ANOS POR GRANDES REGIOES, SEGUNDO O DOMICILIO. 1989.

\begin{tabular}{|c|c|c|c|c|c|c|}
\hline \multirow[b]{2}{*}{ IDADES } & \multirow[b]{2}{*}{ BRASIL } & \multicolumn{5}{|c|}{ GRANDES AEGIOES } \\
\hline & & NORTE & NORDESTE & SUDESTE & SUL & $\begin{array}{l}\text { CENTRO } \\
\text { OESTE }\end{array}$ \\
\hline \multicolumn{7}{|l|}{ TOTAL } \\
\hline 05 & 3.348 .116 & 223.061 & 1.128 .340 & 1.321 .406 & 444.590 & 229.715 \\
\hline 06 & 3.330 .252 & 222.043 & 1.113 .717 & 1.326 .484 & 446.029 & 230.080 \\
\hline 07 & 3.337 .213 & 220.771 & 1.101 .148 & 1.332 .896 & 449.260 & 233.131 \\
\hline 08 & 3.338 .051 & 219.887 & 1.089 .919 & 1.339 .605 & 453.608 & 235.804 \\
\hline 00 & $\mathbf{3 . 3 4 4 . 0 7 8}$ & 210.055 & 1.079 .321 & 1.345 .720 & 458.600 & 242.191 \\
\hline 10 & 3.348 .798 & 218.585 & 1.000 .734 & 1.353 .024 & 484.868 & 242.587 \\
\hline 11 & 3.363 .243 & 218.702 & 1.081 .542 & 1.363 .530 & 472.837 & 246.622 \\
\hline 12 & 3.340 .581 & 216.510 & 1.048 .527 & 1.381 .040 & 475.800 & 247.695 \\
\hline 13 & 3.291 .635 & 210.682 & 1.027 .770 & 1.338 .395 & 470.601 & 244.098 \\
\hline 14 & 3.208 .048 & 202.515 & 1.001 .857 & 1.303 .629 & 460.568 & 237.470 \\
\hline \multicolumn{7}{|l|}{ URBANA } \\
\hline 05 & 2.195 .634 & 107.549 & 537.507 & 1.007 .181 & 290.325 & 154.082 \\
\hline 08 & 2.198 .423 & 107.412 & 532.300 & 1.103 .530 & 290.780 & 155.401 \\
\hline 07 & 2.210 .828 & 108.029 & 530,665 & $1,112,567$ & 301.317 & 158,248 \\
\hline 08 & 2.220 .667 & 109.187 & 531.770 & 1.123 .038 & 303.552 & 182.140 \\
\hline 08 & $2,251,775$ & 110.591 & 534.780 & 1.133 .688 & 308.098 & 166.620 \\
\hline 10 & 2.280 .070 & 112.427 & 539.848 & 1.146 .408 & 300.431 & 171.860 \\
\hline 11 & 2.317 .514 & 114.805 & 547.121 & 1.183 .024 & 314.024 & 178.470 \\
\hline 12 & 2.330 .374 & 115.680 & 550.830 & $1,160.707$ & 315.107 & 181.052 \\
\hline 13 & 2.303.275 & 114.004 & 548.192 & 1.140 .688 & 310.848 & 180.472 \\
\hline 14 & 2.251 .359 & 110.898 & 541.304 & 1.120 .100 & 303.180 & 175.797 \\
\hline \multicolumn{7}{|l|}{ RURAL } \\
\hline 05 & 1.152 .482 & 116.412 & 590.842 & 224.305 & 145.272 & 75.652 \\
\hline$O B$ & 1.140 .828 & 114.631 & 581.417 & 222.853 & 146.248 & 75.578 \\
\hline 07 & 1.128 .387 & 112.741 & 570.481 & 220.330 & 147.851 & 74.884 \\
\hline 08 & 1.109 .284 & 110.700 & 558.149 & 218.628 & 150.144 & 73.664 \\
\hline 09 & 1.093 .203 & 108.465 & 544.541 & 212.034 & 152.592 & 75.571 \\
\hline 10 & 1.068 .717 & 108.157 & 529.888 & 208.818 & 155.435 & 70.818 \\
\hline 11 & 1.045 .729 & 103.898 & 514.421 & 200.444 & 158.814 & 68.152 \\
\hline 12 & 1.019 .207 & 100.830 & 497.688 & 124.333 & 160.612 & 65.743 \\
\hline 13 & 988.360 & 98.588 & 479.579 & 188.727 & 150.843 & 63.624 \\
\hline 14 & 954.689 & 91.817 & 460.553 & 183.439 & 157.390 & 61.682 \\
\hline
\end{tabular}

Fonte: Bibliografiae 127, 128 
TABELA 3

ESTIMATNAS DA POPULACAO UREANA POR GRANDES REOIÓES, COM IDADES EXATAS. 1989

\begin{tabular}{|c|c|c|c|c|c|c|}
\hline \multirow[b]{2}{*}{ IDADES } & \multirow[b]{2}{*}{ BRAGIL } & \multicolumn{4}{|c|}{ GRANDES REGIOES } & \multirow[b]{2}{*}{ C.OESTE } \\
\hline & & NOATE & NORDESTE I & SUDESTE & SUL & \\
\hline$=0-4$ & 11.404 .081 & 582611 & 2.940 .131 & 5.573 .457 & 1.584 .588 & 835.164 \\
\hline 5 & $2,105,034$ & 107,540 & 537.507 & 1.097 .181 & 200.326 & 154.062 \\
\hline 6 & $2,180,423$ & 107.412 & 532.300 & 1.102 .830 & 200.700 & 155.401 \\
\hline 7 & $2,210,820$ & 108,020 & 530.626 & $1,112,507$ & 301.317 & 158.248 \\
\hline $\mathbf{8}$ & $2,200,067$ & 100,167 & 531.770 & 1.120 .038 & 303862 & 182.140 \\
\hline • & $2,251,778$ & 110,501 & 534.700 & 1.132888 & 302.008 & 168.020 \\
\hline - $5-9$ & $11,086,325$ & 542.740 & 2607.022 & 5.870 .012 & 1.810 .072 & 700.471 \\
\hline $\begin{array}{l}10 \\
11\end{array}$ & $2,280,070$ & 112.427 & 530.046 & 1.144 .400 & 300.431 & 171.000 \\
\hline $\begin{array}{l}11 \\
12\end{array}$ & $\begin{array}{l}2,317,514 \\
2,300,374\end{array}$ & $\begin{array}{l}114,805 \\
115,000\end{array}$ & 547.121 & 1.100004 & 314.024 & 178.470 \\
\hline $\begin{array}{l}12 \\
13\end{array}$ & $\begin{array}{l}2,300,374 \\
2,300,275\end{array}$ & 115,600 & 580.830 & 1.104 .707 & 316.197 & 181.052 \\
\hline $\begin{array}{l}13 \\
14\end{array}$ & $\begin{array}{l}2,300,275 \\
2,281,360\end{array}$ & 114,004 & 540.100 & 1.140 .000 & 310.848 & 180.472 \\
\hline 14 & $2,281,360$ & 110,809 & 541.304 & 1.120 .100 & 302100 & 175.707 \\
\hline $10-14$ & $11,482,001$ & 567,004 & 2.727 .303 & 5.740 .005 & 1.582000 & 888.680 \\
\hline 15 & 2203.813 & 107.890 & 534.000 & 1.0002 .248 & 200172 & 171.563 \\
\hline 16 & 2154,187 & 104.708 & 527.927 & 1.004 .870 & 208.713 & 160.050 \\
\hline 17 & 2.117 .001 & 101.700 & 521.071 & 1.047 .343 & 284.108 & 103.280 \\
\hline 18 & 2.108 .812 & $\infty 0.641$ & 515.170 & 1.047 .944 & 284,614 & 161.543 \\
\hline 19 & 2116.052 & 97.677 & 509.400 & 1.000 .480 & 288.165 & 180.043 \\
\hline$-15-10$ & 10.700 .155 & 511.000 & 2000.504 & 5.313 .883 & 1.441 .062 & 824.297 \\
\hline 20 & 2118.202 & 95.500 & 502200 & 1.000 .000 & 290.807 & 150.681 \\
\hline 21 & 2116.360 & 20.181 & 404.234 & 1.077 .840 & 2anous & 158.080 \\
\hline 22 & 2114.050 & $\infty 0.704$ & 403.811 & 1.086 .042 & 206203 & 158.239 \\
\hline 23 & 2113.153 & 88.310 & 470.513 & 1.103 .330 & $2 \operatorname{sen}$ & 154.050 \\
\hline 24 & 2108.044 & 86.789 & 464.787 & 1.118 .770 & 208.041 & 151.540 \\
\hline $20-24$ & 10.871 .878 & 463.632 & 2408.713 & 5.460 .808 & 1.474 .028 & 770.507 \\
\hline 26 & 2102741 & 02.234 & 430.704 & 1.122840 & 201.062 & 148.052 \\
\hline 20 & 2.000 .260 & 80.621 & 422.028 & 1.144 .712 & 200.002 & 140.333 \\
\hline 27 & 2.072 .881 & $\pi .800$ & 404,416 & 1.140 .505 & 208.007 & 142.948 \\
\hline 28 & 2.024 .882 & 74.788 & 383.541 & 1.136 .007 & 291.970 & 138.478 \\
\hline 20 & 1.950 .025 & 71.474 & 381.217 & 9.110 .821 & 283.110 & 133.295 \\
\hline $25-20$ & 10.256 .660 & 388.074 & 2.010 .585 & 5.878 .006 & 1.471 .950 & 710.004 \\
\hline 30 & 1.824 .050 & 68.184 & 330.000 & 1.084 .618 & 274.070 & 128.078 \\
\hline 31 & 1.824 .978 & 04.870 & 318.672 & 1.056 .333 & 204.300 & 122.702 \\
\hline 32 & 1.754 .732 & 81.701 & 207.249 & 1.023 .340 & 254.878 & 117.555 \\
\hline 30 & 1.688 .252 & 58.746 & 282584 & 986.77 & 246.242 & 112.801 \\
\hline 34 & 1.618 .874 & 55.057 & 271.271 & 24.068 & 238.101 & 108.578 \\
\hline $30-34$ & 8.778 .884 & 309.487 & 1.506 .860 & 5.006 .042 & 1.277 .691 & 580.815 \\
\hline 35 & 1.540 .287 & 53.202 & 200.007 & 002.425 & 220.451 & 104.183 \\
\hline 36 & 1.478 .414 & 50.526 & 240.206 & 85. 192 & 220.886 & 09.827 \\
\hline 37 & 1.410 .374 & 47.008 & 230.506 & 816.718 & 211.643 & 05.514 \\
\hline 36 & 1.346 .048 & 45.320 & 230.707 & 776.964 & 202020 & 01.214 \\
\hline 30 & 1.287 .373 & 42.826 & 202751 & 741.145 & 100.600 & 86.002 \\
\hline $36-30$ & 7.072 .376 & 230.783 & 1.202437 & 4.004 .402 & 1.057 .064 & 477.730 \\
\hline 40 & 1.220 .073 & 40.442 & 215.604 & 706.337 & 184.878 & 82.913 \\
\hline 41 & 1.172 .550 & 38.147 & 200.008 & 670.110 & 178.200 & 78.034 \\
\hline 42 & 1.110 .054 & 36.118 & 202.480 & $\mathbf{6 3 7 . 8 3 1}$ & 188,207 & 75.319 \\
\hline 43 & 1.072 .008 & 34.440 & 105.144 & $\infty 00.387$ & 100.033 & 72.184 \\
\hline 4 & 1.028 .421 & 33.027 & 187.400 & 54.156 & 154.308 & 60.434 \\
\hline$\cdot 40-44$ & 5.022 .000 & 182.174 & 1.009 .724 & 3.204 .810 & 24,685 & 378.704 \\
\hline 45 & 8se.e47 & 31.080 & 180.304 & 500.040 & 147.874 & 68.741 \\
\hline 40 & 940.164 & 30.410 & 173.200 & 530.700 & 141.002 & 64.122 \\
\hline 47 & 911.830 & 29.286 & 167.104 & 517.457 & 130.118 & 61.697 \\
\hline 48 & 884.868 & 28.240 & 162.394 & 503.110 & 131.044 & 59.479 \\
\hline 49 & 803.184 & 27.200 & 158.640 & 492.080 & 127.888 & 57.387 \\
\hline $46=49$ & 4.602 .472 & 144802 & 841.602 & 2000.494 & 806,097 & 300.427 \\
\hline 50 & 82.810 & 28.423 & 154.744 & 481.800 & 124.256 & 55.380 \\
\hline 51 & 824.612 & 25.645 & $\$ 51.406$ & 473.081 & 120.070 & \\
\hline 52 & 802.000 & 24.728 & 148.704 & 461.004 & 117.313 & 51.331 \\
\hline 53 & $\pi 1.240$ & 23.553 & 140.043 & 46.202 & 112800 & 48.551 \\
\hline 54 & 735.501 & 22233 & 132.081 & 427.720 & 108.045 & 45.434 \\
\hline $50-54$ & 3.976 .040 & 122.570 & 726.040 & 2200.705 & 503.482 & 254.225 \\
\hline 55 & 701.222 & 20.070 & 124.274 & 410.142 & 103.405 & 42.431 \\
\hline 56 & 660.296 & 10.703 & 115.977 & 302.401 & 28.704 & 30.421 \\
\hline 57 & 038.003 & 18.686 & 100.781 & 374.270 & 94.624 & 30.753 \\
\hline 50 & 612.957 & 17.700 & 108.924 & 302.801 & $\infty .7 \infty$ & 34.035 \\
\hline 50 & 584.306 & 18.224 & 106.018 & 351.074 & 87.406 & 32.884 \\
\hline $56-69$ & 3210.734 & $\infty 0.052$ & 502054 & 1.802778 & 474.027 & 186.123 \\
\hline$\infty$ & 577.405 & 16.307 & 106.868 & 300.002 & 84.281 & 31.217 \\
\hline B1 & 560.640 & 15.785 & 107.757 & 331.408 & 81.784 & 20.818 \\
\hline 62 & 542.350 & 14.006 & 103.951 & 317.228 & 78.102 & 28.075 \\
\hline$\infty$ & 408.748 & 13.743 & 00.485 & 200,420 & 72.406 & 28.708 \\
\hline 84 & 438.275 & 12.270 & 72.087 & 208.042 & 65.781 & 23.077 \\
\hline $60-64$ & 2620.417 & 73.108 & 470.010 & 1.647 .188 & 382342 & 137.800 \\
\hline 86 & 386.681 & 10.946 & 56.467 & 239.852 & 60.712 & 20.005 \\
\hline$\infty$ & 320.342 & 9.563 & 30.041 & 211.246 & 53.327 & 18.275 \\
\hline 87 & 307.053 & 8.840 & 32.616 & 108.752 & 60.653 & 17.084 \\
\hline 60 & 340.580 & 0.547 & 50.415 & 200.584 & 03.300 & 17.748 \\
\hline 60 & 406.977 & 10.005 & 81.845 & 236.084 & 69.653 & 10.580 \\
\hline$\cdot 65-69$ & 1.770 .513 & 40.800 & 257.273 & 1.003 .400 & 276.463 & 03.380 \\
\hline 70 E MANS & 2.756 .171 & 60.503 & 740.781 & 1.464 .620 & 3easu1 & 118.824 \\
\hline - TOTAL & 105.902 .070 & 4.333 .835 & 22.700 .808 & 58.020 .700 & 14.054 .250 & 7.380 .410 \\
\hline
\end{tabular}


: 4.2. Condicões Recentes de Desenvolvimento Nacional: As Crises da Década de Oitenta

- Brasil dos anos oitenta foi um grande cenário marcado principalmente pela violenta crise econômica do início da década e pela deteorização das condições de vida das grandes cidades onde 0 aumento da criminalidade e dos núcleos de pobreza ganharam destaque e dimensões antes desconhecidas. Também um período de renascimento de liberdades politicas gerais e individuais consequente à queda do regime militar que desde 1964 dominava o país. Na comparação com os padrões de crescimento internacionais essa. foi, com base no conceito de desenvolvimento humano adotado pela oNu, uma década de oportunidades perdidas. Surgiram os ruidosos planos macroeconômicos governamentais, do "cruzado" ao "verão", desiludindo ainda mais a população que logo se habituou aos seus fracassos.

\section{:: 4.2.1. A Mudança Política}

- domínio militar, que caracterizara o Brasil e os seus vizinhos do Cone sul na maior parte das duas décadas anteriores, terminou em 1984 após mais de vinte anos de restrições às liberdades individuais e coletivas. O último governo dessa fase, comandado pelo General João Baptista Figueiredo, coincidiu com o auge da crise econômica e também com uma nova postura norteamericana em relação ao continente que resultou na retirada do apoio às ditaduras implantadas na Argentina, no Uruguai, no Brasil e no Chile. Até mesmo o General Alfredo Stroessner teve que deixar - poder cativo que detinha no Paraguai.

Eleito em 1985 pelo Congresso nacional com forte apoio da população, Tancredo Neves não chegou a assumir a presidência da repúbilica, vitimado que foi por uma doença às vésperas da posse. Em seu lugar assumiu o vice José Sarney para exercer ao final um mandato de cinco anos cheio de altos e baixos tanto nas suas políticas econômicas e sociais quanto em relação à própria equipe de governo que sofreu frequentes mudanças, num quadro geral que fez crescer as incertezas e as desconfianças da população. Desde 0 final de 86 o Presidente Sarney governou praticamente sem apoio da população e sob forte pressão do meio politico, adotando a tática da negociação e das composiçōes de interesses para manterse $(2,31,63,81,139)$.

Ainda assim, o simples fato de que em março de 1990 houve a transmissão normal do poder a um presidente eleito democraticamente, constituiu-se em uma importante conquista para um país habituado a governos de curta duração e a traumáticas derrubadas (o último presidente eleito fora Jânio Quadros que iniciou seu mandato em 60 e a êle renunciou em 61).

A partir de 85 a nação entrou em uma fase de maiores liberdades, embora até hoje as eleiçōes ainda permanecem dominadas pelo poder econômico, fazendo com que sejam eleitos majoritariamente os candidatos com maior suporte financeiro. Não obstante, cresceu no país um forte movimento de oposição ao "status 
quo" tradicional, elegendo membros de partidos de esquerda para muitos municipios e quase vencendo a votação presidencial de novembro/dezembro de 1989 com um candidato - Luiz Inacio "Lula" da Silva - pertencente ao Partido dos Trabalhadores. Uma nova divisão do poder, com isto, passou a vigorar no país. O presidente atual, Fernando Collor de Mello, governa com minoria no Congresso Nacional e apesar do acúmulo de poderes que o regime presidencialista lhe confere, com frequência é obrigado a negociar e a voltar atrás nas medidas que procura impor(8i).

\section{:: $\quad 4.2 .2$. A Crise Económica}

Ao inicio do Governo Collor produziu-se nova tentativa de estabilização aproveitando o momento de relativa força e restígio conferido pela eleição recente, mas o fracasso sobreveio cerca de uano dejpois com insucesso das medidas implantadas pela equipe da Ministra Zélia de Mello (logo substituida) e que incluiram o confisco da poupança bancária da população.

Este quadro repetiu-se em toda a América Latina, despreparada que estava para fazer frente aos aumentos constantes nos preços internacionais dos derivados do petróleo e nos juros da dívida externa (63).

Dois choques fizeram a crise: o primeiro em 1981, com medidas recessivas que ocasionaram una queda no Produto Interno Bruto -PIB, em cerca de $4,4 \%$ e uma redução no desempenho do setor indústria em 8,88. Com a negociação junto ao Fundo Monetário Intrernacional FMI, a fim de estancar a rápida deterioraçāo das contas externas, veio o segundo choque recessivo, o mais duro, em 1983, reduzindo o PIB em 3,48 e a indústria em 5,98 $(14,16,68,69)$.

- ritmo de acelerado crescimento alcançado na década anterior (a do "milagre econômico") é estancado e os avanços perdem-se com rapidez, provocando uma importante fissura no chamado ciclo da industrialização da economia brasileira (MPAS/CEPAI, 1990). É a fase da "estagnação socialmente truncada" no dizer de Albuquerque e Villela(2), caracterizada pela queda da produção seguida da elevação das desigualdades de renda e do aumento da pobreza.

A partir de 1984 inicia-se uma recuperaçāo gradual da economia que atinge o seu melhor momento em 1986, quando os níveis de desemprego retornam a padrões menos insatisfatórios(14,16,68,69,131). Daí até 1989 a economia comporta-se de forma inconstante errática, consolidando o quadro de descrédito pelo qual é vista hoje pela população.

- primeiro Plano, dito de estabilização econômica ("Plano Cruzado") veio em 28 de fevereiro de 1986, sendo o de mais triste memória possivelmente por ter sido o que maiores esperanças deu ao país, ao ponto de fazer com que o partido então no governo federal - - PMDB, ganhasse com facilidade as eleiçōes para a grande maioria dos governos estaduais realizadas naquele ano. Com o reagravamento da recessão surgiu o "plano Bresser" em junho de 1987 e ainda ol "Plano Verão" em janeiro de 1989, todos êles tendo como resultados! 
principais não mais que uma interrupção breve no processo recessivo e um reaquecimento de curto prazo na economia $(14,139,205)$.

Ao início do Governo collor produziu-se nova tentativa de estabilização aproveitando o momento de relativa força e prestígio conferido pela eleição recente, mas cerca de um ano depois o insucesso das medidas implantadas pela equipe da Ministra Zelia de Mello (logo substituida) e que incluiram o confisco da poupança bancária da população, tornaram-se também patentes(14,81).

- Quadro 2 apresenta um conjunto de indicadores sociais e econômicos que em boa parte retratam o modelo de desenvolvimento do país no período. São dados coletados pelo IBGE (111), que resumem resultados provenientes das "Pesquisas Nacionais por Amostras de Domicilios- PNADs"(108,109.110) realizadas pela instituição de 1981 a 1989. Foram aqui selecionados alguns indicadores mais representativos para os anos de $1981,83,86$ e 89 a fim de destacar os dois primeiros pontos da crise, o momento de maior recuperação 1986 - e a situação ao final da década.

Em sintese as seguintes constatações surgem através da análise das PNADS 81-89 (111):

- o êxodo da população rural prosseguiu, reduzindo-se a população camponesa de 28,8 para cerca de 26,58 ;

- de um lado houve un aumento de 178 na proporção de idosos (pessoas com 60 anos e mais) e de outro uma diminuição de quase 8 \& no grupo com menos de 18 anos, produzindo uma modificação ainda pequena mas já representativa e tendencial na pirâmide populacional;

- as taxas de analfabetismo no grupo de 7 anos e mais declinaram de $1 / 4$ para $1 / 5$ no periodo, ao passo que ocorreu um aumento significativo (de 18,38 para 24,38 sobre 0 total) das pessoas com 8 anos de estudo ou mais;

- o desemprego atingiu um auge em 1983 com a Taxa de Desocupaçāo abrangendo 4,98 dos homens e 4,88 das mulheres, melhorou bastante em 86 e com altos e baixos situou-se respectivamente em 3,18 e 2,98 em 89 ;

- a proporcão de contribuintes da previdência social em relação à população ocupada não teve alteração na década, mantendose com um fraco desempenho em torno de 508;

- em relação à mão-de-obra, o setor agrícola reafirmou a tendência decrescente dos anos setenta, a indústria de transformação após sofrer forte retração durante a crise maior recuperou-se gradativamente a partir de 85 , a construção civil (que chegou a absorver 9,68 do total das pessoas ocupadas em 83 devido ao deslocamento de trabalhadores agrícolas consequente à grande seca do Nordeste naquele ano) diminuiu bastante sua representatividade durante 0 período $e$, finalmente, constatou-se 
uma sensivel tendência de crescimento na participação do comércio e do setor de serviços;

- as mulheres ingressaram com crescente intensidade no mercado de trabalho, saltando de 31,28 da População Economicamente Ativa PEA- em 81 para 35,28 em 89;

- as familias tiveram seu tamanho reduzido em quase $108(4,3$ pessoas em média em 81 para 3,9 em 89), aumentando a proporção das que tinham ate dois componentes e diminuindo aquelas com sete ou mais pessoas;

- a proporção de domicílios servidos por rede geral de abastecimento d'água e iluminação elétrica aumentou sensivelmente, com um crescimento relativo respectivamente de 21 e 168;

- o Salário Mínimo Real (medido em setembro de cada ano) de 89 foi 16,38 inferior ao de 81 e 18,98 inferior ao de 86 ;

- agravou-se a já pronunciada concentração de renda, com o Coeficiente de Gini (varia de 0 a 1 : quanto mais próximo a 1 , maior concentração) aumentando de 0,55 em 81 para 0,62 em 89 , ao mesmo tempo em que uma minoria de dez por cento das pessoas ocupadas passaram a usufruir 53,28 do total dos rendimentos pagos no país em 89 contra 46,68 no início do período;

De acordo com a Comissão Econômica para a América Latina(63), houve um aumento na proporção de pobres e indigentes no país entre 1981 e 1986: os primeiros passaram de 398 (cerca de 47 milhões de pessoas) para 408 (54 milhöes), enquanto que os indigentes cresciam de 178 (20,4 milhões) para 18\% (24,4 milhōes). Utilizando critérios em parte diversos dos da CEPAL, autores brasileiros concordam com as altas taxas de incidência de pessoas situadas abaixo da linha de pobreza (2,131). Em função do seu tamanho e dos seus problemas internos, o Brasil concentra o maior contingente de pessoas pobres de toda América Latina(19,63,139), atingindo situaçōes críticas nos seus maiores centros urbanos onde a criminalidade aumentou muito na década, atingindo com violência a adultos e a crianças.

Ao estudarem o período mais intenso da crise, 1981-83, Saboia e Tolipan(205) constataram que, na indústria, os estratos populacionais mais prejudicados (houve uma queda de quase um milhão de empregos) foram os mais jovens e os que tinham menor nivel de escolaridade, mostrando uma das faces mais perversas dos tempos de aguda recessão econômica.

A instabilidade e as fortes variações a que foi submetida a economia nacional está bem retratada no Gráfico II, pelo qual vemos que mesmo o Produto Interno Bruto (PIB) total voltou a cair em 1990 interrompendo umma recuperação que vinha desde 85 , prenunciando a nova crise aguda que em 1992 continua assolando a populaçãc brasileira(81). Também em 90 houve uma pronunciada queda no produtc do setor: 7,48 a menos que no ano anterior. Já O PIB per capita, que somente em 87 conseguiu superar a cotação alcançada em 1980, caiu em 5,98 no último ano considerado $(14,16,68,69)$. 
GRÁFICO II

VARIAÇÃO DO PRODUTO INTERNO BRUTO - Em \%

BRASIL $1980-90$

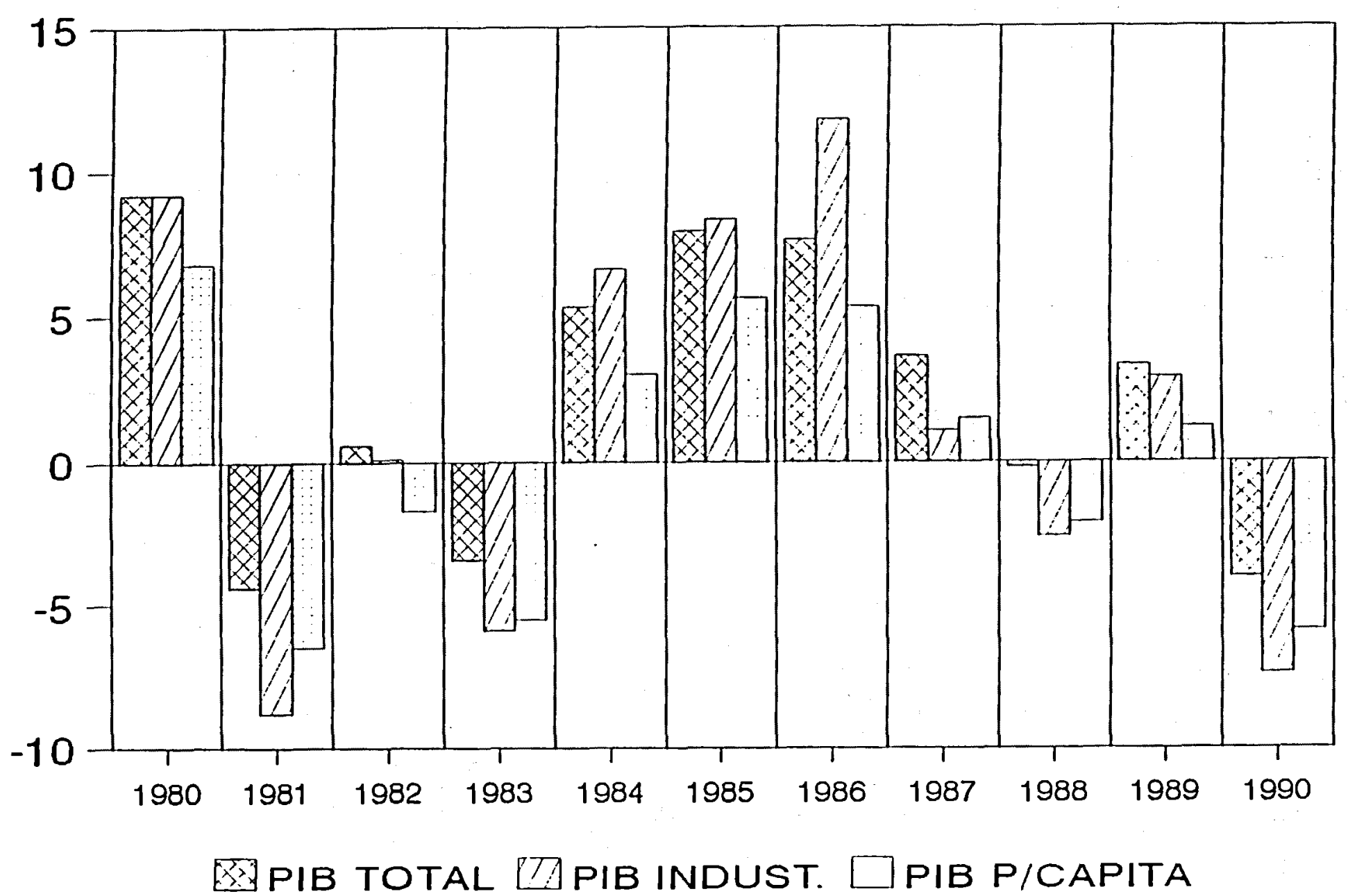

Fontes: Bibliografias 106,142 
QUADRO 2

INDICADORES SOCIAIS - BRASIL, 1981 a 1989

\begin{tabular}{|c|c|c|c|c|c|c|}
\hline INDICADOA & 1981 & 1983 & 1986 & 1989 & $\begin{array}{r}\# 89-81 \\
\theta m \% \\
\end{array}$ & $\begin{array}{l}\# \text { 89-81: } \\
\text { conceito* }\end{array}$ \\
\hline$\%$ LOOSOS $(60 \theta+)$ & 6,4 & 6,6 & 6,9 & 7,5 & +17 & $M$ \\
\hline$\%$ POP. ATE 17 ANOS & 44,7 & 43,9 & 42,6 & 41,3 & $-7,6$ & $M$ \\
\hline $\begin{array}{l}\text { ANALFABETOS: } \% \\
\text { POP. } 10 \text { ANOS } \theta+\end{array}$ & 22,3 & 21,5 & 19.5 & 18.2 & $-18,4$ & $M$ \\
\hline $\begin{array}{l}\text { PESSOAS C/8 ANOS } \\
\text { E + DE ESTUDO } \%)\end{array}$ & 18,3 & 19,8 & 22,3 & 24,3 & $+32,8$ & M \\
\hline $\begin{array}{l}\text { NUMERO MÉDIO DE } \\
\text { PESSOASIFAMÍLIA }\end{array}$ & 4,3 & 4,2 & 4,1 & 3,9 & $-9,3$ & $M$ \\
\hline $\begin{array}{l}\text { FAMÍLIAS COM ATE } 2 \\
\text { PESSOAS: } \%\end{array}$ & 22,6 & 23,7 & 24,3 & 25.8 & $+14,2$ & $M$ \\
\hline $\begin{array}{l}\text { FAMILIAS COM } 7 \text { E + } \\
\text { PESSOAS: } \%\end{array}$ & 15,7 & 13,9 & 11,9 & 9,6 & $-38,8$ & M \\
\hline $\begin{array}{l}\text { \% DOMICIL.SERVIDOS } \\
\text { REDE ABAST. AGUA }\end{array}$ & 60.1 & 64,6 & 69,9 & 72,7 & $+21,0$ & M \\
\hline $\begin{array}{l}\text { \% DOMICILIOS CI } \\
\text { ILUMIN. ELETRICA }\end{array}$ & 74,9 & 77,9 & 83,2 & 86,9 & $+16,0$ & $M$ \\
\hline $\begin{array}{l}\text { TAXA DE DESOCUPAÇẢO } \\
\text { LABORAL }\end{array}$ & 4,3 & 4,9 & 2,4 & 3,0 & $-30,2$ & M \\
\hline $\begin{array}{l}\text { CONTRIB. PREV.SOCIAL } \\
\text { (\%/PESSOAS OCUP.) }\end{array}$ & 49,9 & 47,7 & 49,9 & 50,6 & $+1,4$ & $\mathbf{E}$ \\
\hline $\begin{array}{l}\text { PESSOAS OCUPADAS NA } \\
\text { IND.TRANSFORM.(\%) }\end{array}$ & 16.6 & 15,8 & 17.7 & 17,5 & $+5,4$ & E \\
\hline $\begin{array}{l}\text { PESSOAS OCUPADAS NA } \\
\text { IND.CONS.CIVIL (\%) }\end{array}$ & 8.1 & 9,6 & 6.5 & 6,2 & $-23,5$ & M \\
\hline $\begin{array}{l}\text { \% PESSOAS OCUP.QUE } \\
\text { GANHAM ATE I S.M. }\end{array}$ & 23,0 & 29,7 & 15,7 & 27,2 & $+18,3$ & $\mathbf{P}$ \\
\hline $\begin{array}{l}\text { \% PESSOAS OCUP. QUE } \\
\text { GANHAM + DE } 10 \text { S.M. }\end{array}$ & 5,1 & 4,4 & 8.4 & 8,2 & $+60,8$ & $\mathbf{P}$ \\
\hline $\begin{array}{l}\text { \% FAMILIAS C/REND. } \\
\text { MENSAL ATE } 1 \text { S.M. }\end{array}$ & 16,6 & 16.9 & 12,0 & 13,2 & $-27,7$ & $M$ \\
\hline $\begin{array}{l}\text { \% FAMILIAS C/REND. } \\
D E+D E 10 \text { S.M. }\end{array}$ & 10,7 & 11,0 & 16,0 & 18,0 & $+68,2$ & $M$ \\
\hline $\begin{array}{l}\text { INDICE GINI: DISTR. } \\
\text { REND.MENSAL DAS } \\
\text { PESSOAS OCUPADAS }\end{array}$ & 0,553 & 0,573 & 0,573 & 0,618 & $+11,7$ & $P$ \\
\hline $\begin{array}{l}\text { RENDIMENTO MÉDIO } \\
\text { MENSAL (Valores } \\
\text { reals 1989:NCz\$) }\end{array}$ & 739 & 635 & 1042 & 928 & $+25,6$ & $M$ \\
\hline $\begin{array}{l}\% \text { RENDA AUFERIDA } \\
\text { PELOS } 10 \%+\text { PICOS }\end{array}$ & 44,0 & 46.3 & 47,9 & 53,6 & $+21,9$ & $\mathbf{P}$ \\
\hline
\end{tabular}

Fonte: Bibliogratia

- Critérios: M= Melhor; E= Estavel: Pa Pior.

\# - Dilerença 
:: 4.2.3. Comparações Internacionais: a décaḍa perdida

Na análise de um conjunto de indicadores sociais constantes do Quadro 3, vemos que o Brasil não tem uma situação melhor que o conjunto da América Latina e Caribe ou do que seus vizinhos do Cone Sul (7). De fato, levamos desvantagem relativa em diversos casos, como em relação à taxa de inflação, à esperança de vida, ao percentual de analfabetos ou à taxa de mortalidade infantil, por exemplo.

A Organização das Nações Unidas -ONU, através do seu Programa para o Desenvolvimento (PNUD) edita a partir de 1990 um Informe sobre o Desenvolvimento Humano. O estudo fundamenta-se numa vasta bateria de indicadores sociais e constroi um "Indice de Desenvolvimento Humano -IDH" que permite uma comparação entre os países. O IDH procura medir a longevidade, o conhecimento e a renda com base na combinação das taxas de esperança de vida ao nascer, de alfabetização e escolaridade média e, ainda, $O$ PIB per capita ajustado pela proporção da população sob a linha de pobreza(184). O IDH varia de 0 a 1 , sendo a situação ideal $=1$. O Quadro 4 reune dados relativos ao IDH de vinte países selecionados entre um total de 160, mostrando o Brasil como uma nação de desenvolvimento humano médio, ocupando somente a 602 . posição no concerto internacional.

O informe inicial(185) inclui uma dura análise sobre o Brasil, considerando-o junto à Nigéria e ao Paquistão no grupo das oportunidades perdidas na década de oitenta. Em síntese, 0 informe da ONU coloca que o Brasil falhou no alcance de um desenvolvimento humano satisfatório não obstante seu rápido crescimento, a elevação relativa dos níveis de renda e um gasto substancial do governo em setores sociais. Duas razões são apresentadas no citado documento para explicar o fracasso: a extrema desigualdade na distribuição da renda (uma das piores do mundo, com um Coeficiente de Gini estimado em 0,60 em $76-0,56$ em 80 e 0,57 em 83) que inclui agudas diferenças regionais, e o direcionamento ineficiente dos recursos públicos os quais terminaram por não chegar aos mais pobres, servindo mais para fortalecer setores de intermediação privada (185).

Isto ocorre numa etapa histórica em que o mundo sofre fortes e surpreendentes modificaçōes politicas: os regimes socialistas da Europa Oriental se modificam, na Suécia os sociais democratas são derrotados pelos liberais pois o povo parece insatisfeito apesar de seu pais ser o primeiro em niveis de bem estar de todo o mundo, as nações industrializadas experimentam umm crescimento sem precedentes. Retratando em grande parte as idéias e conceitos dos grupos econômicos neo-liberais (entre os quais se destaca a linha do "Thatcherismo") que se opōem às teorias e práticas do "welfare state" recente publicação desenha as tendências para a década atual(159) do mundo já desenvolvido e do mundo que está dando certo, como os chamados "tigres asiáticos" (Coréia, Japão, Cingapura, Hong Kong, Taiwan). É curioso notar que do ponto de vista do capitalismo internacional, de acordo com esta publicaçāo, nada de importante parece passar-se no Brasil. Somos o grande devedor munaial e um dos mais bem comportados pois aqui as ameaças de comoção social têm 
sido razoavelmente bem contidas pela estrutura de poder nacional. 0 Brasil e a América Latina figuram fora do mercado e nenhuma das dez mega-tendências para a década incluem a região.

Não há dúvida de que apenas uma forte dose de auto-iniciativa e de reorganização interna poderá fazer com que a crise que ainda persiste seja substituida por tempos de maior prosperidade que signifiquem a superação dos atuais niveis de privação.

Com base nos mesmos critérios utilizados pela onU em seu Informe 90 (em 91 os critérios foram aperfeiçoados e não correspondem exatamente aos divulgados no ano anterior), Albuquerque e Villela (2) construiram um IDH nacional que confirma as intensas diferenciações internas $(19,220)$. Para um IDH global de 0,794 em 1988, há uma variação de 0,575 no Nordeste - a região de maior carência sócio-econômica - até 0,872 no Sul, a área mais desenvolvida $(0,780$ no Norte $-0,818$ no Centro Oeste e 0,852 no Sudeste) e, em termos estaduais de 0,469 na Paraiba a 0,907 no Rio Grande do Sul. A expectativa de vida ao nascer era de 58,8 anos no Nordeste e de 70,1 anos no Sul, enquanto que O PIB per capita (em dólares de 88) apresentava uma variação bem mais extrema: 918 dólares no Nordeste, 1401 no Norte, 1949 no Centro Oeste, 2382 no Sul e 3217 no Sudeste, para uma média nacional segundo o estudo de US\$ 2241 .

- presente capítulo procurou fazer uma breve análise dos padrões de desenvolvimento nacional na década de oitenta, caracterizada pela depressão econômica e pelo aumento das desigualdades entre as pessoas e entre as regiões após uma fase de relativo avanço na década anterior. Estes acontecimentos foram determinantes na vida nacional e influenciaram fortemente 0 comportamento dos setores sociais e, nestes, particularmente da área da saúde. 
QUADRO 3

INDICADORES DE SAÚDE, DE RENDA E DEMOGRÁFICOS

PARA O BRASIL E PAISES OU REGIOES SELECIONADOS

\begin{tabular}{|c|c|c|c|c|c|c|c|c|}
\hline INDICADOR & BRASIL & $\begin{array}{l}\text { A. LATINA } \\
\text { E CARIBE }\end{array}$ & $\begin{array}{l}\text { ARGEN- } \\
\text { TINA }\end{array}$ & URUGUAI & IPARAGUAI & CHILE & $\begin{array}{l}\text { PAISES } \\
\text { INDUST. }\end{array}$ & MUNDO \\
\hline $\begin{array}{l}\text { PNB per capita } \\
\text { em dolares } 89\end{array}$ & 2540 & 1950 & 2160 & 2620 & .1030 & 1770 & 18330 & 3980 \\
\hline $\begin{array}{l}\text { INFLAÇAO ANUAL } \\
\text { em } \% 80-89\end{array}$ & 227,8 & 160,7 & 334,8 & 59,2 & 23,2 & 20,5 & 4,6 & 13,2 \\
\hline $\begin{array}{l}\text { EXP. VIDA AO } \\
\text { NASCER } 89\end{array}$ & 66 & 67 & 71 & 73 & 67 & 72 & 76 & 65 \\
\hline $\begin{array}{l}\% \text { ANALFABETOS } \\
15 \text { anos } \theta+, 85\end{array}$ & 22 & 17 & 5 & 5 & 12 & 6 & $\ldots$ & $\ldots$ \\
\hline $\begin{array}{l}\text { TAXA MEDIAIANO } \\
\text { CRESC.POP.80-89 }\end{array}$ & 2,2 & 2.1 & 1,4 & 0,6 & 3,2 & 1,7 & 0.7 & 1,8 \\
\hline $\begin{array}{l}\text { POPULAÇĀO 0-14 } \\
\text { anos:\% em } 89\end{array}$ & 22,8 & 36,6 & 29,9 & 20,0 & 41,1 & 30,7 & 20,5 & 32,6 \\
\hline $\begin{array}{l}\text { TAXA MORT.INF.I } \\
1000 \text { N.V. }-89\end{array}$ & 59 & 50 & 30 & 22 & 32 & 19 & 9 & 54 \\
\hline POP.URBANA:\% 89 & 74 & 71 & 86 & 88 & 47 & 85 & 77 & 49 \\
\hline $\begin{array}{l}\text { CRESC. POP.URB. } \\
\% \text { ao ano:80-89 }\end{array}$ & 3,5 & 3,1 & 1,8 & 0,8 & 4,6 & 2,3 & 0,9 & 4,5 \\
\hline
\end{tabular}

Fonte: Bibliografia 7 
QUADRO 4

INDICE DE DESENVOLVIMENTO HUMANO PARA

20 PAISES SELECIONADOS - 1988

\begin{tabular}{|c|c|c|c|c|c|}
\hline $\begin{array}{l}\text { PAIS } \\
\text { ALTO D.H. }\end{array}$ & I.D.H. & CLASSIF. & ALTO D.H. & I.D.H. & CLASSIF. \\
\hline JAPÄO & 0,993 & 1 & $\mathrm{CEI}$ & 0,908 & 31 \\
\hline CANADÁ & 0,983 & 2 & URUGUAI & 0,905 & 32 \\
\hline SUÉCIA & 0,982 & 4 & PORTUGAL & 0,879 & 36 \\
\hline EUA & 0,976 & 7 & C.RICA & 0,876 & 40 \\
\hline N.ZELĀNDIA & 0,959 & 15 & ARGENTINA & 0,854 & 44 \\
\hline MÉDIO D.H. & & & BAIXO D.H. & & \\
\hline PANAMÁ & 0,796 & 54 & BOLIVIA & 0,416 & 110 \\
\hline ROMĖNIA & 0,762 & 58 & QUENNIA & 0,399 & 113 \\
\hline BAASIL & 0,759 & 60 & INDIA & 0,308 & 123 \\
\hline TAILÃNDIA & 0,713 & 66 & ETIOPIA & 0,166 & 141 \\
\hline CHINA & 0.614 & 82 & SERRA LEOA & 0.046 & 160 \\
\hline
\end{tabular}

Fonte: Bibliografia 184 


\section{: 4.3. O Sistema de Atenção à Saúde}

Após muitos anos de luta, o setor saúde encontrou um caminho para reestruturar-se durante a década de oitenta. A reorganização do sistema deu-se no bojo da maior recessão econômica já enfrentada pelo país em sua história moderna, não conseguindo - como seria de esperar-se - melhorar as condições de atendimento à população. Ao contrário, acumulou dificuldades que viriam a explodir através de uma crise particular do setor saúde em 1990.

De maneira sintética este capítulo procura examinar esse quadro, em cinco tópicos, enfocando questões relacionadas ao nível de saúde, à oferta e consumo de serviços, ao financiamento, à evolução setorial e à crise.

\section{:: 4.3.1. Condições de Saúde da População}

Houve um inegável progresso, na década de oitenta, em termos dos mais conhecidos indicadores de saúde da população. Assim, a expectativa de vida ao nascer aumentou em cerca de seis anos, 0 coeficiente de mortalidade geral reduziu-se de 39 para 27 por mil e - coeficiente de mortalidade infantil diminuiu em cerca de $338(7,112,130,221)$.

A estrutura geral de mortalidade sofreu modificações graduais acompanhando as tendências de urbanização e de maior envelhecimento relativo da pirâmide etária, apresentando como cinco principais causas de óbitos - ao final da década - pela ordem, as doenças do aparelho circulatório, as causas externas (acidentes, suicídios,etc.), as doenças infecciosas e parasitárias que antes costumavam liderar as estatisticas, os neoplasmas e as doenças do aparelho respiratório. Entre os homens as causas externas ocupam a 2a. posição e os neoplasmas a $3 a$., enquanto que nas mulheres são os neoplasmas e as doenças do aparelho respiratório que estão respectivamente em 20 e em $39(10,109,110,111)$.

$\dot{E}$ interessante observar que amorbidade, medida indiretamente através das estatisticas de internaçōes hospitalares na rede contratada do INAMPS (124) conforme a Tabela 4, difere do quadro de mortalidade oficial. São as "complicaçōes da gravidez, parto e puerpério" que lideram as causas de internação. Junto com as "doenças do aparelho gênito-urinário", que figuram em 5o. Iugar, indicam muito provavelmente os eféitos práticos da elevada prevalência de interrupções extemporâneas da gravidez e suas sequelas, num país onde o aborto segue sendo um crime.

Nessas condiçōes, não deve surpreender em demasia a constatação da Pesquisa Nacional Sobre Saúde e Nutrição $(121,122)$, de que nada menos que 258 das mulheres entre 10 e 54 anos referiram ter tido alguma gravidez interrompida com menos de sete meses de gestação.

o mesmo estudo colheu dados da maior importância sobre morbidade sentida pelas pessoas. As respostas da população ao questionário sobre saúde indica, por exemplo, que num período de 
duas semanas, cerca de 16,9 milhōes de brasileiros informaram ter tido febre; 19,8 milhões dor de garganta; 14,5 milhões problemas dentários; 34,4 milhões dor de cabeça; 12 milhōes dor de barriga e 5,9 milhōes diarréia; 13,3 milhões problemas respiratórios; 25,3 milhões nervosismo ou depressão; 4,7 milhões sofreram ferimentos ou queimaduras. Nada menos que 12,8 milhões de pessoas faltaram nesse periodo às suas atividades normais com uma média de 4,74 dias de afastamento e 26,5 milhões procuraram atendimento de saúde (122).

- mais extraordinário nos dados da Tabela 4, contudo, referese ao elevadíssimo número de dias de internação dedicados aos "transtornos mentais" que representam $36 \%$ do total. De acordo com informações provenientes da Divisão de Saúde Mental do Ministério da Saúde(124), os doentes mentais ocupam cerca de $1 / 5$ dos leitos disponiveis no país, sendo que do total de 95 mil leitos psiquiátricos existentes em 1988 - 748 deles públicos - 47 mil são ocupados pela mesma pessoa por mais de cinco anos. Na verdade, a grande massa de leitos está ocupada por problemas que exigem ou baixa permanência ou cuidados apenas de hotelaria elementar aos doentes, significando lucro mais fácil ou mínimo trabalho.

As variações anuais na mortalidade infantil, mostrada na Tabela 5, refletem em parte os efeitos da crise econômica sobre o setor. Há uma tendência declinante global, mas três períodos bastante nitidos podem ser identificados: de 80 a 82 ocorre uma diminuição acentuada no coeficiente; em 83 e 84 no climax da crise observa-se um aumento e finalmente verifica-se um novo descenço a partir de $85(10)$.

A chamada Mortalidade Infantil Tardia, ou seja, a que se verifica entre 0 280. dia de vida e 1 ano é a maior responsável pela diminuição do coeficiente, por relacionar-se mais diretamente com os problemas.. infecciosos da infância (doenças respiratóriase imuno-preveníveis, septicemias, infecçōes intestinais) e por ser mais sensivel a açōes de saúde como as vacinaçōes e a reidratação oral. Quanto às causas, as doenças infecciosas intestinais, principalmente as doenças diarreicas, é que sofreram as mais drásticas reduçōes ${ }^{(10)}$.

Mesmo assim, as doenças infecciosas intestinais permanecem sendo a primeira causa de óbito em crianças de até um ano de vida, seguidas pelas infecciosas respiratórias agudas, septicemias, causas congênitas, prematuridade e só depois pela desnutrição. Estudos realizados por profissionais da Escola Nacional de Saúde Pública (163), no Rio de Janeiro, corrigindo os atestados de óbito com entrevistas feitas com"os pais, mostra que muitas crianças com menos de um ano não morrem nos hospitais e sim em casa ou nas ruas, e que a subnụtrição é fortemente subestimada (de 13,28 do total para 26,58 nesise estudo).

As diferenças regionais continuam muito pronunciadas, assia como entre populações urbanas e rurais. Em 1986, por exemplo, a probabilidade de morte antes de completar um aro de vida no Nordeste era superior em 139\%-à da região Sul(112.130). 
A prevalência da desnutrição em menores de cinco anos de idade é de 318 ( 188 no Sul e 468 no Nordeste) atingindo cerca de 5 milhões de crianças, das quais $806 \mathrm{mil}$ nas formas moderada e grave (122). Embora muito elevada, a proporção de desnutridos encontrada na Pesquisa Nacional de Saúde e Nutrição é inferior à constatada em 1974 pelo ENDEF, de $46 \%$ no país.

Doenças há muito sob controle no país, como o dengue e a cólera, não só voltaram a manifestar-se como o fizeram de maneira violenta levando a que os poucos recursos usualmente disponíveis para o combate de todas as endemias fossem empregados quase que com exclusividade no seu combate. Com isto, outros problemas endêmicos e típicos de países pobres como o nosso por vezes tiveram suas atividades descontinuadas ou mesmo interrompidas. É o caso, para citar apenas as principais, da malária, da esquistossomose, da doença de chagas e da leishmaniose. A hanseníase manteve-se em níveis surpreendentemente elevados, da mesma forma que as doenças sexualmente transmissiveis agora sumamente agravadas com 0 acréscimo da AIDS. 
TABELA 4

INTERNAÇOES HOSPITALARES NA REDE CONTRATADA DO INAMPS

SEGUNDO O MOTIVO - BRASIL, 1989

\begin{tabular}{|c|c|c|c|c|}
\hline DIAGNÓSTICO & $N^{\circ}$ (mil) & IENTES & $\begin{array}{c}\text { DIAS DE } \\
\text { INTERNAÇĀO } \\
N^{\circ} \text { (mil) }\end{array}$ & $\%$ \\
\hline $\begin{array}{l}\text { 1.Complic. Gravidez, } \\
\text { Parto.Puerpério }\end{array}$ & 1673 & 23.15 & 4125 & 7,41 \\
\hline 2. D.Ap.Respiratório & 1128 & 15,61 & 6559 & 11,79 \\
\hline 3. D.Ap.Circulatório & 859 & 11,88 & 6612 & 11,88 \\
\hline 4. D.Int.e Parasitárias & 689 & 9,54 & 3876 & 6,97 \\
\hline 5. D.Ap.Genitourinario & 658 & 9,11 & 2946 & 5,30 \\
\hline 6. D.Ap.Digestivo & 552 & 7,64 & 2806 & 5,04 \\
\hline 7. Causas Externas & 341 & 4.71 & 1848 & 3,32 \\
\hline 8. Transtornos mentais & 264 & 3,65 & 19891 & 35,75 \\
\hline $\begin{array}{l}\text { 9. Demais causas } \\
\text { 10. TOTAL }\end{array}$ & $\begin{array}{l}1063 \\
7227\end{array}$ & $\begin{array}{r}14,71 \\
100,00\end{array}$ & $\begin{array}{r}6975 \\
55638\end{array}$ & $\begin{array}{r}12,54 \\
100.00\end{array}$ \\
\hline
\end{tabular}

Fonte: Bibliografia 123 
TABELA 5

PROBABILIDADE DE MORTE ANTES DE COMPLETAR

UM ANO DE VIDA - BRASIL, 1980 A 1989

(por 1000 nasc. vivos)

\begin{tabular}{lcccc}
\hline LOCAL & 1980 & 1984 & 1986 & $1989^{\circ}$ \\
\hline URBANO & 85,6 & 59,6 & 58,2 & $\ldots$ \\
RURAL & 93,8 & 87,4 & 84,7 & $\ldots$ \\
\hline TOTAL & 87,9 & 68.1 & 66.9 & 59.0 \\
\hline $\begin{array}{l}\text { NOTA : Estimado segundo IPEANUNICEF } \\
\text { Fonte: Bibliografia 221 }\end{array}$
\end{tabular}


:: 4.3.2. Oferta e Consumo de Serviços Públicos

Os serviços de saúde no Brasil são predominantemente públicos na área ambulatorial e privados na área hospitalar. Nos anos oitenta constatou-se um aumento de representatividade do setor público, invertendo a tendência das décadas anteriores. Esta tendência, expressa em termos da participação nas consultas médicas e nas internaçōes hospitalares, ocorreu mais em função do crescimento da rede pública do que pelo encolhimento da rede privada.

A Tabela 6 mostra o número e o percentual de unidades de saúde existentes, indicando por exemplo que o setor privado detém 18 dos Centros de Saúde e 838 dos Hospitais, concentrando seu poder de fogo nas atividades mais lucrativas.

A relação entre os setores público e privado quanto aos serviços prestados está retratada nas Tabelas 7 e 8 , onde se vê que 578 das consultas médicas, $18 \%$ das internaçōes, 468 dos serviços de apoio ao diagnóstico e 528 das consultas odontológicas ligadas ao INAMPS são feitas em unidades oficiais $(106,119,120,123,124)$.

Comparando-se os diversos prestadores de serviços entre 80 e 89 vemos que:

\section{a) Consultas Médicas}

- houve um aumento acentuado nos anos de crise econômica;

- a rede pública expandiu sua participação em 85 e 86 , mantendo-se desde aí no mesmo patamar. O crescimento deu-se através dos órgãos governamentais e das universidades, em grande parte via incorporação dos chamados "serviços próprios" previdenciários, face às fortes mudanças na politica do INAMPS nesses anos;

- a rede contratada lucrativa, embora tenha reduzido sua participação relativa desde 85 , manteve um ritmo crescente quanto ao número total de consultas que subiu de 52 milhōes para 59 milhões em 88, baixando para 43,4 milhōes somente em 89, numa aparente resposta do setor privado à baixa remuneração praticada pelo INAMPS;

- a rede filantrópica, formada principalmente pelas Santas Casas de Misericórdia, aumentou sua representatividade percentual mas diminuiu o número de consultas prestadas no período;

b) Hospitalizações

- após um comportamento virtualmente constante. nos oito primeiros anos da década, o número de internaçōes hospitalares deu um salto em 88 e 89 , subindo da média anual anterior de 11,2 milhões para 13,2 milhões. Não obstante, reduziu-se a proporção de internaçōes por 100 habitantes que situava-se em torno de 9,5 em 1980 e em 9,16 em 89; 
- o setor público cresceu muito (1638) no período, fazendo-o via órgãos governamentais até 86 e via Universidades de maneira continua;

- os Hospitais privados lucrativos tiveram altos e baixos, passando da média de 8,5 milhōes de internaçōes/ano no primeiro quinquênio para 7,6 milhões no segundo e fechando $89 \mathrm{com} \mathrm{1,1} \mathrm{milhão}$ de internações a menos que em 80;

- muito significativo foi o crescimento dos hospitais ditos filantrópicos (apenas a instituição o é, pois os médicos que aí trabalham comportam-se como se estivessem numa clínica contratada comum).

Quanto às imunizações, a cobertura anual média obtida de 1987 a 1989 em relação às principais doenças evitáveis por vacinação, foi de $61 \%$ das crianças para o sarampo, $56 \%$ para a tríplice, $71 \%$ para a BCG e $54 \%$ para a poliomielite. Estes percentuais são praticamente idênticos, com pequenas diferenças para mais ou para menos, aos obtidos nos triênios 85-87 e 82-84(130,231), revelando uma preocupante estagnação dos programas de imunização em torno de taxas sem dúvida baixas e insuficientes de proteção à sua população-alvo. 
TABELA 6

ESTABELECIMENTOS DE SAÚDE NO BRASIL SEGUNDO O TIPO COM O PERCENTUAL DE UNIDADES PÚBLICAS - 1989

\begin{tabular}{lcc}
\hline ESTABELECIMENTO & NÚMERO & $\begin{array}{c}\% \text { DE UNID. } \\
\text { PÜBLICAS }\end{array}$ \\
\hline CENTRO DE SAÚDE & 6320 & 99 \\
HOSPITAL & 5756 & 17 \\
POLICLINICA & 9633 & 41 \\
POSTO DE SAUDE & 7533 & 98 \\
PRONTO SOCORRO & 346 & 40 \\
UNIDADE MISTA & 670 & 81 \\
LEITOS (mil) & 502 & 25 \\
\hline
\end{tabular}

Fontes: Bibliografias 106, 123. 
TABELA 7

CONSULTAS MÉDICAS FEITAS ATRAVÉS DO INAMPS:

DISTRIBUIC̄ÃO PERCENTUAL SEGUNDO O PRESTADOR. BRASIL 1980/89

\begin{tabular}{|c|c|c|c|c|c|c|c|c|c|c|}
\hline PRESTADOR & 1980 & 1981 & 1982 & 1983 & 1984 & 1985 & 1986 & 1987 & 1988 & 1989 \\
\hline PÚBLICOS & 45,8 & 46,2 & 45,8 & 45,9 & 47,7 & 52,5 & 56,6 & 56,9 & 54,1 & 56,9 \\
\hline RÓPRIOS & 32,9 & 28,5 & 27,1 & 24,4 & 22,1 & 22,2 & 21,0 & 19,0 & 16,6 & 16,6 \\
\hline ORG.GOVERN. & 11,1 & 15,4 & 16,0 & 18,2 & 22,1 & 26,3 & 31,8 & 33,8 & 33,1 & 33,4 \\
\hline UNIVERSID. & 1,8 & 2,3 & 2,7 & 3,3 & 3,5 & 4,0 & 3,8 & 4,1 & 4,4 & 5,9 \\
\hline PRIVADOS & 54,2 & 53,8 & 54,2 & 54,1 & 52,3 & 47,5 & 43,4 & 43,1 & 45,9 & 43,1 \\
\hline CONTRATADOS & 29,0 & 29,9 & 30,9 & 32,6 & 32,0 & 28,0 & 26,6 & 24,5 & 24,8 & 21,2 \\
\hline FILANTROP. & 11.5 & 10,1 & 9,3 & 8,5 & 7,9 & 7,7 & 2,6 & 6,6 & 10,2 & 12,5 \\
\hline SINDICATOS & 9,4 & 9,0 & 9,1 & 8,8 & 8,5 & 8,1 & 7,3 & 6,4 & 5,9 & 5,8 \\
\hline OUTROS CONV. & 4,3 & 4,8 & 4,9 & 4,1 & 3,9 & 3,7 & 6,9 & 5,6 & 5,0 & 3,6 \\
\hline $\begin{array}{l}\text { NÚMERO DE } \\
\text { CONSULTAS } \\
\text { (milhoes) }\end{array}$ & 179,7 & 202.6 & 206,3 & 218,6 & 235,7 & 238,4 & 237,5 & 246,6 & 237,2 & 204,7 \\
\hline
\end{tabular}

Fonte: Bibliografia 123 
TABELA 8

INTERNAÇŐES HOSPITALARES FEITAS ATRAVÉS DO INAMPS:

DISTRIBUIÇĀO PERCENTUAL SEGUNDO O PRESTADOR.BRASIL-80 A 89

\begin{tabular}{lrrrrrrrrrr}
\hline PRESTADOR & 1980 & 1981 & 1982 & 1983 & 1984 & 1985 & 1986 & 1987 & 1988 & 1989 \\
\hline PÚBLICOS & 7,6 & 9,6 & 10,9 & 13,6 & 14,7 & 17,8 & 19,8 & 18,3 & 17,9 & 17,7 \\
& & & & & & & & & & \\
PRÓPRIOS & 1,9 & 1,6 & 1,8 & 2,0 & 1,8 & 2,0 & 2,1 & 2,0 & 1,7 & 1,5 \\
ORG.GOVERN. & 4,1 & 6,3 & 7,1 & 8,7 & 9,9 & 12,2 & 13,8 & 12,4 & 11,2 & 11,1 \\
UNIVERSID. & 1,6 & 1,7 & 2,0 & 2,9 & 3,0 & 3,6 & 4,0 & 3,9 & 5,0 & 5,1 \\
& & & & & & & & & & \\
PRIVADOS & 92,4 & 90,4 & 89,1 & 86,4 & 85,3 & 82,2 & 80,1 & 81,7 & 82,1 & 82,3 \\
& & & & & & & & & & \\
CONTRATADOS & 71,7 & 69,7 & 67,1 & 64,4 & 66,5 & 62,8 & 67,0 & 63,1 & 61,3 & 55,0 \\
FILANTROP. & 4,1 & 3,9 & 3,6 & 3,5 & 3,2 & 3,3 & 8,3 & 15,4 & 18,0 & 26,1 \\
SINDICATOS & 0,2 & 0,2 & 0,1 & 0,2 & 0,1 & 0,1 & 0,1 & 0,1 & 0,1 & 0,1 \\
OUTROS CONV. & 16,4 & 16,6 & 18,3 & 18,3 & 15,5 & 16,0 & 4,7 & 3,1 & 2,7 & 1,1 \\
\hline FOnte: Bibliografia & & & & & & & & & &
\end{tabular}




\section{:: 4.3.3. Evolução do Sistema}

A Lei do Sistema Nacional de Saúde de 1975 nunca conseguiu impor-se nem reduzir os abismos que tradicionalmente separavam os vários atores presentes no cenário do setor saúde, como os grupos privados, os sanitaristas, as empresas, etc. e, mal foi aprovada, reacendeu-se a luta e multiplicaram-se os projetos e programas para substitui-la. As análises deste tópico baseiam-se principalmente em documentos e estudos que procuram sintetizar a história no último lustro $(18,20,21,32,62,66,71,148,177,200,231)$.

- Programa Integrado de Ações de Saúde e Saneamento -PIASS, criado em 1976 foi o início do grande esforço de descentralização que se seguiria e que teve um momento importante quando da tentativa não concretizada de aprovar o PREVSAUDE em 1980, um programa conjunto do Ministério da Saúde, da Previdência Social e dos estados $(32,177)$.

Buscando racionalizar os contratos e os mecanismos de repasse de recursos previdenciários, surgiram em 1982 as Ações Integradas de saúde, com o mérito de aproximar os quatro Ministérios com atividades na área (Saúde, MPAS, Educação e Trabalho).

A verdadeira abertura das discussões sobre a organização do setor aconteceu a partir de 1985 com a redemocratização do país. Com a realização da VIII Conferência Nacional de Saúde em 1986 ganhou vida a chamada "Reforma Sanitária" que passou a concentrar os esforços de reformulaçāo da área. Os grupos privados boicotaram a VIII Conferência, mas em compensação deu-se uma ampla participação de outros setores da sociedade, quebrando a tradição das discussões fundamentalmente fechadas em torno dos profissionais da saúde. 
- SUDS - Sistema Unificado e Descentralizado de Saúde(65) chega em 1987, e com êle começa a efetiva desestabilização da velha estrutura previdenciária. O INAMPS sofre uma violenta comoção a partir de dentro, sucedendo-se a transferência de suas unidades e de seu pessoal para as Secretarias de Saúde dos Estados, via convênios feitos em geral às pressas pelo então Ministro Raphael de Almeida Magalhães com os governadores. 0 processo acelerado de transferência produziu muitas distorçōes (gastos em atividades extranhas ao setor, falta de controles, poucas modificações nos serviços para a população), mas terminou por consolidar-se nas administrações seguintes apesar das resistências dos grupos mais conservadores ou mesmo dos que desejavam que o processo fosse conduzido com maior racionalidade(200).

Enquanto as Iutas internas, os avanços e os retrocessos se sucediam, na ponta da linha os serviços de saúde continuavam praticamente com a mesma lógica de funcionamento. Os investimentos que já eram reduzidos escassearam ainda mais durante a crise econômica agravando o processo conhecido como de "sucateamento" da rede de saúde. O empobrecimento relativo da previdência social, fruto do empobrecimento do país, alertou a iniciativa privada que em resposta começou rapidamente a diversificar suas aplicaçōes, afastando-se da previdência social (menor pressão sobre as Iinhas de pagamento dos contratos e convênios) e investindo com vigor na expansão das modalidades de pré-pagamento que desde aí se consolidam em definitivo no Brasil.

A Constituição de 1988(18) com um capítulo específico sobre a saúde, foi aprovada ao tempo em que o suDs estava em implantação e a crise de atendimento se aprofundava nas clínicas e hospitais.

Em síntese, a nova lei constituinte estabeleceu que "a saúde é um direito de todos e um dever do estado", determinando que é livre à iniciativa privada (considerada como complementar ao setor público) embora seja vedada a participação de empresas ou capitais extrangeiros. Ficou consagrado o Sistema único de Saúde -SUS, com ações e serviços públicos formando uma rede que deveria passar a funcionar de maneira regionalizada e hierarquizada segundo três grandes diretrizes: descentralização, com direção única em cada esfera de governo; atendimento integral com prioridade para as açōes preventivas e, finalmente, a participação da comunidade. 0 Sú foi incluido no campo da Seguridade Social, dividindo recursos com a previdência e a assistência social como no antigo modelo que vigora no Brasil desde a criação dos serviços previdenciários(20,21).

$\mathrm{Na}$ prática o sUS restringiu-se ao setor público, evitando qualquer interferência mais significativa no âmbito da rede privada.

Seguindo-se a cerca de dois anos de discussão, em setembro de 1990 foi aprovada a Lei orgânica da Saúde -IOS, que discrimina 0 texto constitucional, estabelecendo normas principalmente em relação aos objetivos, campos de atuação e princípios do sus, competências de cada esfera de governo, participação complementar da iniciativa privada e financiamento setorial. A saúde é 
conceituada como um direito fundamental do ser humano. A gratuidade das ações e serviços de saúde da área pública ficou assegurada.

Diversas proposiçōes aprovadas pelo Congresso foram vetadas pela Presidência da República, retirando da LOS(20) questões como direitos salariais (plano de cargos e salários, piso nacional por categoria profissional), base financeira visando assegurar recursos mínimos para o sus e cotas para os municípios, além de aspectos organizacionais como a incorporação de serviços de saúde da LBA ao SUS (177).

Pouco depois, a Lei $8.142(21)$ procurou definir critérios sobre a participação da comunidade, organização dos Conselhos de Saúde e repasse de recursos.

Todo esse esforço legislativo deixou um importante núcleo de matérias não resolvidas e que compõem a pauta de lutas dos trabalhadores de saúde de hoje. Essas matérias dizem respeito essencialmente a três tópicos: recursos humanos, direção única incluindo a municipalização e o financiamento. Os dois primeiros pontos são resumidamente analisados a seguir, ao passo que os aspectos ligados ao financiamento constituem o tema do tópico seguinte neste Capitulo.

\section{a) Politicas de pessoal}

A remuneração dos profissionais do setor público continua muito baixa. A implantação do SUS fez com que passassem a conviver técnicos com os mais distintos padrōes salariais, aquecendo as reivindicações de isonomia. A inexistência de recursos para tanto provocou um dos vetos presidenciais, mas não foram apresentadas soluções alternativas e a reduzida competitividade do setor público em relação à iniciativa privada continua. Nem mesmo a adoção de tempo integral e de lugar único de trabalho foi conseguida, embora em alguns estados tenham ocorrido avanços nesse sentido. A "dupla militância" (profissionais que trabalham parte do tempo em cada setor, público e privado, em geral favorecendo o segundo) continua $e$ as discussōes sobre uma maior profissionalização do setor público, criando-se uma carreira a exemplo dos diplomatas e militares, no momento estão relegadas ao limbo.

\section{b) Direção única e Municipalização}

A LOS não avançou muito em relação ao pouco estabelecido pela Constituição quanto ao conceito e à prática da direção única do sistema em cada esfera de governo. A União mantém poderes e atribuições que conflitam com os que cabem aos Estados e Municípios. As Secretarias Estaduais de Saúde ficaram com funções pouco claras que as deixam entre os poderes central e local, pois ihes compete basicamente promover a descentralização, acompanhar e avaliar as ações produzidas pela rede, participar da programação e executar de maneira supletiva serviços de saúde. Como a força politica dos governos estaduais persiste dentro da estrutura politica brasileira, os conflitos em torno dos limites de atribuições ainda são um problema significativo na área da saúde, 
ainda que seja inegável que a força e a importância dos municípios aumentou muito desde a implantação do sus.

A municipalização é a bússola principal do atual processo de reorganização e de relacionamento entre os três nívei's de governo, mas vem ocorrendo com lentidão e mais como o resultado de novas politicas de repasses de recursos do que de um processo de fortalecimento dos serviços locais e de concretização dos distritos de saúde que representam a unidade básica do sistema. Na prática, os sistemas municipais enfrentam, além dos problemas em relação aos poderes estaduais, uma forte resistência ao seu crescimento e consolidação em função da arraigada tradição centralizadora do país (as comunidades têm reduzida força política e limitada autonomia) e à desconfiança alimentada por instituições e pessoas para com $c$ governo federal. Este último sentimento faz com que as administrações locais temam, com fundadas razões, ver transferidas para suas portas as filas que hoje estão em repartições federais como o INAMPS, sem que lhes fique assegurado o repasse regular de verbas ou sem que estas sofram frequentes defasagens motivadas por artificios embutidos nos muitos planos econômicos governamentais.

A unificação INAMPS/Secretarias e Ministério da Saúde é um processo em andamento que já tem resultados formais importantes mas que também não conseguiu ainda produzir melhoras visíveis no atendimento às pessoas e às comunidades. Ao contrário, em alguns casos tem provocado consequências negativas devido à desarticulação do modelo tradicional sem que o substitua por algo melhor. $\hat{E} 0$ caso, p.ex., das consultas médicas nos "próprios" do INAMPS, que atendiam mesmo que precariamente a segmentos sociais dos mais carentes e que sofreram descontinuidades ou mudanças desfavoráveis de normas e critérios ao passarem para secretarias de Saúde não habituadas a este tipo de serviço.

- INAMPS foi incorporado ao Ministério da Saúde e praticamente - dominou: afora a questão essencial do combate à cólera, a direção do Ministério em 90 e 91 deu tratamento claramente prioritário aos problemas ligados à rede previdenciária, tratando de fazer funcionar a complexa máquina assistencial existente através de tentativas de racionalização dos repasses financeiros e do combate aos desvios e fraudes comuns a essa área.

As ações clássicas de saúde pública passaram a enfrentar maiores dificuldades de desenvolvimento, em parte devido a mudanças administrativas promovidas pelo novo governo em 1990. Dois exemplos parecem significativos a respeito: de um lado, a união da Fundação SESP e da SUCAM (além da ex-Secretaria Nacional de Ações Básicas de Saúde-SNABS) em uma só entidade, a Fundação Nacional de Saúde, fez acender sentimentos corporativistas muito fortes arraigados nas duas unidades e ainda não viabilizou uma desejada integração de açōes a nível local; de outro lado a desarticulação dos chamados "programas especiais" provocou a descontinuidade de projetos importantes como nas áreas de combate à AIDS, à tuberculose e a problemas de saúde bucal, além de diminuir drasticamente o papel de unidades de peso como a de saúde materno-infantil sob a 
argumentação de que as atividades passariam, no novo sus, a ser em essência normativas.

\section{:: 4.3.4. Financiamento da Saúde na Seguridade Social}

Como parte integrante do sistema de seguridade social, para obter os recursos de que necessita a saúde concorre orçamentariamente com pelo menos outras cinco fortes linhas de gastos: beneficios previdenciários (aposentadorias, pensōes, etc.), assistência social, seguro desemprego, alimentação/nutrição e a ação comunitária. Os recursos, por seu turno, provém de seis fontes principais: contribuições compulsórias dos assalariados (cerca de 478 da receita total estimada para 1989), FINSOCIAL (10\%), receita de loterias (1\%), contribuição sobre lucros de empresas (11\%), PIS/PASEP (1z), orçamento dos Ministérios do setor (24\%) e a provisão para fundos de previdência e saúde $(68)(147,149)$.

A Constituiçăo de 88 não assegurou recursos minimos para a saúde como o fez em relação à educação, mas determinou que até a aprovação da Lei de Diretrizes orçamentárias -LDo, que teve sua 1 a. edição em 89 - 308 no mínimo do orçamento da seguridade social, com exceção do seguro desemprego, cabe á saúde. Dispositivo idêntico incluido na LDO para 1991 foi vetado pelo Poder Executivo. Em seguida a Lei $8.142 / 90$ determinou que os municípios que preencherem uma série de seis requisitos passam a receber 708 dos recursos transferidos ao estado pelo Fundo Nacional de Saúde(21). Falta clareza, porém, quanto ao montante transferido por essa via, além de que os repasses feitos até o final de 1991 continuavam obedecendo em essência a tradição (volume de serviços anteriormente prestados) e o critério da representatividade populacional que em geral é punitivo para os estados de menor densidade demográfica e maior nível de pobreza.

Os seis requisitos não são facilmente satisfeitos por parte da maioria dos municípios e podem joga-los em intricados liames burocráticos ensejando negociações morosas e não automáticas mormente onde as dissençōes politicas forem relevantes, inviabilizando o processo. A simples leitura desses critérios já permite antever os problemas com que devem defrontar-se as localidades menores, com estrutura administrativa debil ou onde 0 executivo não tenha maioria na câmara: criação de un Conselho Municipal de Saúde, composto por representantes do governo local, dos prestadores de serviços, dos profissionais da área e dos usuários, organizados de forma paritária; criação do Fundo Municipal de Saúde; apresentação do plano Municipal de Saúde aprovado pelo Conselho e pelo Executivo Municipal; instituição da Programação e orçamentação em Saúde (PROS); contrapartida de recursos em proporção não inferior a 108 do orçamento; constituição de uma Comissão de Elaboração do Plano de Carreiras, Cargos e Salários a implantar em 2 anos(53,54,71,115,117,149).

Conforme a Resolução $258 / 91$ do INAMPS, "os municípios que não preencherem os requisitos terão seus recursos repassados à Secretaria Estadual de Saúde, que adotarão critérios próprios de distribuição"(117). Parece lógico que, a prosseguir o processo nessa 
linha, ai se desenha um campo fértil para as empresas de consultoria e assessoria que começam a proliferar no setor.

Dados da própria previdência indicam que foram repassados à saúde apenas 228 e 208 dos recursos aplicados respectivamente em 1989 e $1990(123,124)$.

Recente bateria de normas e critérios produzida pelo Ministério da Saúde - Portarias 15 a $20 / 91$ e Resolução 258 do INAMPS - ataca fundamentalmente a questão da uniformização de modalidades de pagamento, criando formas unificadas de remuneração para todos os prestadores, sejam êles públicos ou privado.

o setor saúde, em seu todo, movimenta um volume de recursos que a priori não pode ser tido como insuficiente. Em 1989 os gastos federais em saúde alcançaram a cifra de NCr\$ 27,5 bilhões (US\$ 9,7 bilhões), dos quais 78,18 provenientes do INAMPS; 18,68 do Ministério da saúde e 3,38 do Ministério da Educação (231). De acordo com as estimativas feitas no Capítulo 6, o dispêndio total alcançou uma soma em torno de 22,1 bilhöes de dólares, 0 que equivale a 78 do Produto interno Bruto.

Em termos proporcionais o gasto brasileiro supera, por exemplo, ao do Canadá e do Reino Unido que dispendem respectivamente 5 e 68 do PIB com saúde; embora no nosso caso isto signifique 153 dólares per-capita e, nos dois países citados, cerca de 758 e 625 dólares (149).

Considerando as condições econômicas nacionais, não há como justificar um gasto superior a este, pelo menos sem que antes haja uma séria reestruturação setorial que permita um uso mais equânime (acesso mais universal aos serviços) dos recursos.

Uma distorção importante diz respeito à curiosa combinação entre fontes e usos dos recursos. Assim, por exemplo, em 89 cerca de $38 \%$ dos recursos federais foram repassados aos Estados $e$ Municípios, enquanto que $26 \%$ serviram para remunerar serviços privados contratados(123,231). Sem dúvida, seria mais simples e mais correto de um lado que a organização tributária viabilizasse a captação de recursos por parte de quem efetivamente os vai usar $e$, de outro lado, que os subsidios à iniciativa privada representassem uma parcela bem mais reduzida dos recursos públicos permitindo que fossem gastos diretamente com os serviços oficiais.

No momento, uma das principais lutas no âmbito público está em regulamentar os repasses de recursos federais para estados e municípios (artigo 35 da Lei 8080/90), tornando-os mais automáticos. 


\section{$:: 4.3 .5$. A Crise Setorial}

Nada acontece de repente e por acaso. As dificuldades foram se acumulando: a falta geral de recursos, os investimentos cada vez mais insignificantes, a voracidade do setor privado contratado, as fraudes consentidas abismando a população e lesando a previdência social, os baixos salários, a não implementação dos planos ou a substituição constante de programas e de dirigentes, as lutas internas do setor muitas vezes predominantemente ideológicas e pouco pragmáticas. Enfim, uma crescente descaracterização do atendimento médico que se tornou cada vez mais impessoal, conduzindo ao fortalecimento da descrença popular em relação aos serviços de saúde.

- resultado foi a instalação de uma crise particular do setor saúde que se fez sentir mais notoriamente no período de abril a agosto de 1990.

A breve análise que se segue a respeito dessa fase apoia-se principalmente no que foi publicado nos jornais da época, uma vez que não há bibliografia técnica específica disponível e que a externalização da crise deu-se através da chamada grande imprensa nacional. Sempre que é feita uma citação, identifica-se sua origem com as iniciais de um dos periódicos consultados ( Jornal do Brasil=JB, Estado de São Paulo=ESP) e a data de publicação(162,163)'.

As manchetes e as principais páginas dos jornais pouco a pouco povoaram-se de más notícias sobre o setor saúde:

- "Demissão de 17 diretores de hospitais no Rio" (JB 7/4);

- "Ministro flagra em Minas horror da saúde pública" (JB 5/5), referindo-se a visita a PAM (Posto de Assistência Médica) de urgência do INAMPS na Santa Casa de Misericórdia de Belo Horizonte onde "morreram sete pessoas em doze dias por falta de atendimento";

-" Denúncia contra Hospitais" (JB 8/5) informando sobre morte de menina de 4 anos sem atendimento em clínica de Sta.Cruz, no Rio;

- "A romaria das mães pelos hospitais que se recusam a atender as crianças é uma das principais causas de morte" (ESP 20/5), em entrevista de profissional do Hospital Municipal João XXIII de são Paulo;

- "Bebê é a 9a. vítima em fila para internação" (JB 10/5).

Os Hospitais entraram na linha de fogo: no de Andaraí os leitos foram reduzidos à metade por falta de pessoal, no de Bonsucesso a emergência tem capacidade para 100 pacientes e atende 500, o Hospital Geral do INAMPS de Nova Iguaçú é ao mesmo tempo uma frente de batalha e um inferno (JB 7/4 e ESP 27/5). Em Recife dos 280 leitos do Hosp. G.Vargas só 180 estão disponíveis, enquanto no Agamenon Magalhães "foram suspensas as cirurgias e reservou-se 0 estoque de oxigênio e medicamentos para a maternidade, emergência e UTI" (JB 6/7). No Hospital Sto.Antonio de Irmã Dulce de Salvador 
"mais de mil pacientes se amontoam nos coredores e nos 600 leitos existentes" (JB 11/5). "Hospital de Pato Branco (onde o Ministro da Saúde já teve participação e clinicou) omite socorro (JB 11/5).

A reação da classe médica fez-se sentir com certa energia, embora a grande maioria preferisse o silêncio e a espera de que a situação se acalmasse. Mas nas poucas entrevistas muito do que acontece dentro da rede de serviços e na administração pública e privada transparece. O presidente do Sindicato dos Médicos do Rio declara que "antes da má administração dos Hospitais está a má administração do próprio INAMPS que sucateou os Hospitais da rede privada conveniada" (JB 8/5). No Rio O Presidente da Federação nacional dos Médicos "acusou 0 Ministro de estar jogando a população contra os médicos, em vez de enfrentar a crise através da ampliação do SUS" (JB 13/5). As surpreendentes palavras do presidente do Conselho Regional de Medicina de São Paulo: "eu temo, se for atropelado, ir a qualquer Hospital público de São Paulo, e são raras exceçôes os Hospitais privados que dão boa assistência...estão todos sucateados" (ESP 20/5). Nesse mesmo jornal estão declaraçōes dos dirigentes do CRM e APM/SP de que "as fraudes verificadas no INAMPS detonaram o caos atual ... a rede hospitalar pública é insuficiente e os estabelecimentos privados desativaram leitos destinados à previdência", e de um professor de clínica médica tentando justificar a categoria em função do caos mais amplo: "os nossos médicos são tão bons quanto êles podem ser neste país".

Em outra ponta da crise estavam os profissionais de saúde com seus pequenos salários: "Greve na saúde é quase esquecida" (JB 7/4); "Hospitais estaduais em greve há um mês e meio" (JB 8/5) sobre Minas Gerais; "Rede estadual em greve há 30 dias" (ESP 18/5) informando sobre demissão de médicos na Bahia; "Greve atinge hospitais em Belo Horizonte e Curitiba" (ESP 23/5). Mais tarde, são os próprios servidores da previdência que param: "Em greve quase 200 mil funcionários do INAMPS" (ESP 7/9) e "Greve pode atrapalhar vacinação" (ESP 14/9).

A população fica assustada e $O \mathrm{JB}$ de $25 / 5 / 90$ destaca que "Inflação perde no IBOPE para a saúde", informando que "pela primeira vez desde 'o fim do Plano Cruzado em dezembro de 86, a inflação deixou de ser o problema número um dos brasileiros. Agora, - inimigo público é a saúde". O fenômeno, até então muito raro, voltou a repetir-se mais de uma vez em 1991 traduzindo 0 permanência e o aprofundamento da crise. Em matéria de 19/12/91, p.ex., O mesmo JB informa que para $39,2 \%$ dos brasileiros 0 principal problema é a saúde $(37,48$ referiram a inflação; 34,380 desemprego; 33,88 a corrupção; 25\% a falta de alimentos; 23,18 0 mau governo e 18,28 a segurança pública, mas a liderança nesta pesquisa ficou com a edućaçāo que alcançou $47,88(\mathrm{JB}, 19 / 12 / 91, \mathrm{pg} \cdot 5)$.

A crise de 1990 foi geral e afetou a credibilidade de todo o setor, mas abateu-se principalmente sobre o setor público e sobre a área do INAMPS, terminando por beneficiar indiretamente as clínicas e hospitais privados. Um reflexo dessa situação pode ser visto através da expansão do número e da clientela das empresas de grupo 
(linhas de pré-pagamento compostas por cooperativas médicas, caixas de assistência, sistemas de auto-gestão médica e planos empresariais de saúde), para onde passaram a ser direcionados os capitais privados a partir das dificuldades de caixa da previdência e do seu crescente desprestígio.

No último trimestre do ano os jornais, rádios e televisões passaram a ocupar-se de outros temas mais relevantes e a crise a esse nível esvai-se, com o noticiário reservado à saúde voltando ao usual, sendo dominado quase que com exclusividade pelo surto de cólera. Aos olhos do público a crise acaba sem solução, e uma das consequências mais notórias é $O$ aumento da descrença e do temor pelos serviços de saúde oferecidos pelo país. Não é de surpreender que os problemas setoriais tenham voltado à tona com redobrado vigor no segundo semestre de 91, quando agudizou-se a falta de recursos federais para remunerar os hospitais contratados, as tentativas de solução feitas pelo governo não tiveram êxito e, afinal, uma verdadeira onda de processos de corrupção que cercaram as compras efetuadas pelo Ministério da Saúde terminaram aerando a substituição de sua direção.

o desejado e cada vez mais necessário fortalecimento dos serviços públicos ficou mais distante, pois é preciso antes recuperar a desgastada imagem setorial.

A odontologia, como profissão ou como ação de saúde, permaneceu virtualmente à margem deste movimento. Ao não ver questionados seus problemas, optou pelo silêncio. 


\section{O APARELHO PRESTADOR DE SERVIÇOS ODONTOLÓGICOS}

- modelo de prestação de serviços odontológicos à população continua sendo ao início dos anos noventa predominantemente liberal. Não chega a constituir um verdadeiro sistema de atenção em saúde bucal, pois não possui uma estrutura que the dê unidade, funcionando suas diversas partes de maneira independente ou com um limitado nível de relacionamento entre si. Apresenta, em sua essência, a lógica do setor privado liberal, no qual prevalecem as leis de mercado com as distorções próprias impostas a essas "leis" pelas particularidades do setor saúde de maneira geral e pelas formas usuais de entendimento entre pacientes e profissionais em especifico.

Em 1.989 um total de 101,9 mil Cirurgiōes-Dentistas figuravam como inscritos nos Conselhos Regionais de Odontologia(27,61,70), embora o mais provável seja de que não mais de $85 \%$ estejam em atividade(3,61,134,179). Em instituiçōes públicas ou para-oficiais, 40,6 mil empregos diretos ou indiretos responsabilizavam-se por aproximadamente 298 do tempo disponivel dos profissionais ativos. Isto significa, portanto, que cerca de 718 do tempo total estava dedicado ao trabalho em clínica particular ou junto a instituições privadas, em condições que, na prática, tornam inviável o acesso da maior parte da população, por falta de capacidade de pagamento dos serviços odontológicos em função dos baixos salários recebidos.

Apesar das dificuldades que a escassa disponibilidade de dados causa, é possivel afirmar que os gastos com odontologia - e principalmente os desembolsos pessoais - aumentaram de maneira significativa na década: estima-se que no ano de 1989 em torno de 2,4 bilhões de dólares foram gastos com saúde bucal no país, cabendo às instituições do setor público junto com as entidades para-oficiais apenas $30 z$ desse total os gastos pessoais foram de US\$ 1,7 bilhão).

Uma série de programas públicos foram intentados no Brasil a partir da segunda metade da década de setenta, podendo-se definir o período 1980/89 como una fase de reorientação do setor, caracterizado pelo aprofundamento e por uma maior democratização das discussōes, com importantes mudanças conceituais que levaram ao encontro de novas soluções no campo da saúde pública, embora ainda sem repercussão efetiva sobre a rede de prestação de serviços ou mesmo sobre o nível de saúde das pessoas. A prevenção ganhou uma ênfase bem maior, mas no início dos anos noventa observa-se un refluxo das idéias e propostas de especialistas direcionadas para avanços mais lentos e gradativos, após significativos progressos na linha de sua massificação obtidos pouco antes, quando a fluoretação da água chegou a atingir mais de 60 milhões de pessoas e 0 Ministério da Saúde colocou em prática um projeto de aplicação tópica de flúor para cerca de 7 milhöes de crianças em idade escolar. 
Este capitulo procura analisar essa variada gama de acontecimentos, desde as questōes ligadas à formação de recursos humanos até a oferta de serviços e seu financiamento, dando ênfase às principais tendências verificadas na década passada a fim de fornecer uma melhor base para o bloco de sugestōes de políticas e de medidas práticas que é apresentado ao final.

\section{: 5.1. Oferta de Profissionais no Pais}

A quantidade de Cirurgiōes-Dentistas continuou aumentando de maneira acelerada no Brasil, mantendo o comportamento delineado já a partir do período $1965 / 70$ quando foi aberto o caminho para a implantação generalizada de faculdades particulares de odontologia.

De acordo com a Tabela 9, tinhamos 101.880 CirurgiõesDentistas inscritos nos Conselhos Regionais de Odontologia em 1989. A acentuada tendência à maior presença de mulheres na profissão resultou em que 42,98 do contingente total fosse do sexo feminino, com destaques para o estado da Paraiba onde sua representatividade alcançava a 668 e para Santa Catarina onde essa proporça se Iimitava a $31,98(24,25,61,70,201)$.

Em função de diversos fatores - entre outros, sub-emprego, redução voluntária do tempo diário de trabalho (comum por exemplo a profissionais com interesses fora da odontologia ou a mulheres que dedicam tempo parcial à profissão), aposentados que permanecem inscritos no Conselho - estima-se que não mais de 858 dos Cirurgiōes-Dentistas são profissionalmente ativos. De maneira um pouco mais adequada poder-se-ia dizer que 15\% do tempo disponivel para a prática da odontologia não é efetivo, mas para melhor vizualização prática dessa questāo a Tabela 9 inclui uma coluna na qual o total de 85531 profissionais ativos corresponde a $85 \%$ dos inscritos $(3,61,72,134,179)$.

Com base nessas estimativas, tinhamos 1 odontólogo em atividade para cada 1664 pessoas no país em 1989 , variando o

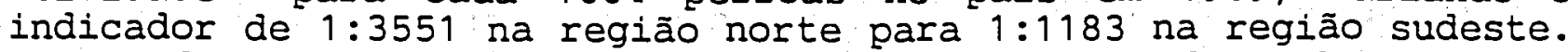
São Paulo, Distrito Federal e Rio de Janeiro, pela ordem, são as unidades federadas que mostram as relações mais estreitas, ao passo que Tocantins, Maranhão e Acre figuram no polo oposto, acompanhados de perto por Roraima e Bahia.

Em 1980 o Brasil contava com 61628 odontólogos inscritos nos Conselhos(48,179). Isto significa que nesses dez anos (80 a 89) 0 estoque de profissionais cresceu extraordinariamente na ordem de 65,38 , ao passo que a população brasileira aumentava em 208. Na verdade, a disponibilidade de odontólogos vem crescendo a taxas cada vez mais elevadas nos últimos trinta anos. A relação Cirurgião-Dentista por 10.000 habitantes era igual a 3,28 em 1960, passando para 3,65 em 1970 , para 5,13 em 1980 e para 7,07 em 1989, com uma estimativa de chegar a 7,26 em $1990(70,179,181)$ A justificativa para este fato certamente não pode ser encontrada na melhora substancial do poder aquisitivo da população, uma vez que isto näo ocorreu como vimos na análise econômica desenvolvida no Capítulo 4. As causas mais prováveis estão, de um lado, no forte 
apelo que o carater liberal da profissão representa em uma sociedade na qual a luta por salários dignos é cada vez mais difícil e, de outro lado, na suposição comum de que neste "país de desdentados" as necessidades de tratamento são, tão elevadas que não haverá de faltar ocupação para quantos queiram deste ofício ocuparse.

Tomando-se as estatisticas publicadas pela Federação Dentária Internacional(84) como referência, temos que em 1989 aproximadamente 118 dos odontólogos existentes na face da terra eram brasileiros, com tendência de uma representatividade crescente se considerarmos que os tradicionalmente grandes centros formadores de recursos humanos nesta área - Estados unidos e países europeus - vem adotando uma política de restrição de novas vágas e diminuição até mesmo do número total de odontólogos disponíveis para a próxima década.

No Brasil, o aumento da oferta de vagas é a regra. A década de oitenta repetiu o comportamento verificado no decênio anterior, permitindo a criação de dezoito novos cursos de formação de odontólogos. A Tabela 10 relaciona os cursos por dependência administrativa desde a época de criação do primeiro curso, em Salvador da Bahia em 1889, até janeiro de 1990 quando 81 cursos superiores estavam disponíveis(24,25,27,48). Nesse ano e no começo de 1991 já foram criados três outros, elevando o total para 84(61).

A contar de 1961 houve um aceleramento no "boom" de novas faculdades, mas foi nos anos setenta que o setor privado efetivamente interessou-se pelo ramo da formação de CirurgiöesDentistas. Até então, uma escola de odontologia era tida como de maior risco econômico em relação por exemplo à implantação de cursos de ciências sociais ou de economia, devido aos seus altos custos e a una ainda limitada procura. A situação mudou quando esta, que por vezes é tida como "a última das profissões liberais", passou a ganhar mercado tornando-se mais competitiva ao conquistar a preferência de um crescente número de candidatos ao ingresso nas carreiras universitárias. Nos concursos de acesso à universidade realizados em 90 e 91 , a relação de candidatos por vaga da odontologia praticamente só foi superada pela verificada na medicina.

- fenômeno da expansão da oferta de vagas ocorre fundamentalmente nos cursos privados, como se pode observar através da Tabela 11: o número de matrículas diminuiu em 7,48 nos cursos do setor público de 1988 para 1990 , ao mesmo tempo em que aumentou em 16,008 nas escolas particulares, dai resultando um incremento global da ordem de $3,78(27)$.

Curiosamente, não se confirmaram até aqui as previsōes de fortes aumentos no número de concluintes, que se mantém nos últimos três anos similar ao verificado por exemplo em 1979 e 80 . Na verdade, desde 1979 - quando o patamar de cinco mil novos profissionais formados foi rompido, as variações não tem sido muito significativas. Esta constataçăo fica clara quando se examina os dados da Tabela 12 que nos fornece os concluintes ano a ano desde 
1954, mostrando que os maiores saltos ocorreram por volta de 1968/69, depois em 1974, logo em $76 / 77$ e finalmente em 79/80, para alcançar $o$ padrão de aproximadamente 5500 concluintes ao ano somente no final da última década. Provavelmente, isto se passa pela possibilidade que o sistema de ensino brasileiro dá de conclusão dos cursos universitários em um número de anos bem maior que o exigido pelos currículos normais - hipótese que se aplicaria mais aos cursos novos, e pela tendência recente de retardamento no ingresso na vida profissional, que estaria influindo também no alongamento interno dos cursos universitários.

Uma projeção com base no comportamento verificado no período 54-90(24,25), feito pela técnica da análise de regressão, indica que no ano 2000 o Brasil formará cerca de 7269 odontólogos, como mostra a Tabela 12. Nesse caso, o estoque de profissionais chegará a um número entre 1.15 e $129 \mathrm{mil}$, dependendo da proporção dos que se retirarem do mercado a cada ano - 5q na primeira hipótese e 3,58 na segunda.

A discussão sobre a necessidade e a validade de controlar e reduzir o acesso a profissões super povoadas como a odontologia no Brasil, conta com argumentos pró e contra que têm resultado num aumento regular dos cursos ano a ano. A Associação Brasileira de Ensino Odontológico chegou a obter junto ao Ministério da Educação uma suspensão de abertura de novos cursos, mas o Conselho Federal de Educação tem permitido excecões mesmo que durante breves lapsos de tempo permitindo que mais e mais cursos surjam a cada ano.

Os neo-liberais, cujas teorias tem ganho espaço crescente principalmente nos países industrializados, consideram mais apropriado deixar esta questão para que o próprio mercado se encarregue de resolve-la com 0 tempo por meio de suas leis naturais. Assim, um previsível esgotamento de mercado - fazendo com que as possibilidades de ganho em clínicas privadas e de criação de novos empregos no setor público ou para-oficial atingissem a um ponto crítico - regularia a procura pela profissão. De acordo com esta Iinha de pensamento, novos cursos poderiam continuar a ser autorizados e abertos até o momento em que "naturalmente" não tivessem mais procura. Na verdade, isto não ocorre, pois é conhecida a capacidade que têm as ciências médicas de criar novas demandas para si próprias, introduzindo um componente nāo natural no clássico processo de relações entre a ciência econômica e o mercado tão bem descrito por Keynes.

É evidente que a discussão principal deveria centrar-se em um ponto anterior à da formação dos recursos humanos. A discussão principal está em como chegar a índices aceitáveis de saúde bucal para a população brasileira, daí derivando tanto o modelo de formação de pessoal quanto o volume de pessoal necessário em cada categoria (odontólogos, técnicos, auxiliares) e que a sociedade poderia suportar. Mesmo em uma economia não centralizada como a brasileira, lou seja de tipo capitalista, no qual o Estado embora detenha parcela significativa do PIB, năo dirige a economia como ocorre nos países socialistas), deveria portanto ser possível adequar a área de formação de récursos humanos de nível acadêmico 
às condições epidemiológicas, fazendo com que em carreiras como a de odontologia o crescimento no número de profissionais pelo menos se adequasse aos padrōes de crescimento populacional. 
TABELA 9

NÜMERO DE CIRURGIOES-DENTISTAS INSCRITOS NOS CONSELHOS, EM ATIVIDADE, PERCENTUAL DO SEXO FEMININO E RELACCOES COM A POPULAC̨ÃO SEGUNDO O ESTADO - BAASIL. 1989

\begin{tabular}{|c|c|c|c|c|c|c|}
\hline $\begin{array}{l}\text { ESTADO } \\
\text { E REGIAO }\end{array}$ & TOTAL & $\begin{array}{l}\text { EM ATIVI- } \\
\text { DADE* }\end{array}$ & \begin{tabular}{|l|}
$\%$ SEXO \\
FEMININO
\end{tabular} & $\begin{array}{c}\text { POPULACÁO } \\
\text { (mil) }\end{array}$ & $\begin{array}{l}\text { PESSOAS POA } \\
\text { C.D. TOTAL }\end{array}$ & EM ATIV.: \\
\hline NORTE & 2613 & 2221 & 48,8 & 7888 & 3019 & 3551 \\
\hline$A C$ & 82 & 70 & $\ldots$ & 328 & 4000 & 4686 \\
\hline$A M$ & 550 & 467 & 46,0 & 1702 & 3094 & 3644 \\
\hline AP & 73 & 62 & $\ldots$ & 205 & 2808 & 3306 \\
\hline PA & 1395 & 1186 & 51.4 & 3971 & 2847 & 3348 \\
\hline RO & 379 & 322 & 37,2 & 812 & 2142 & 2522 \\
\hline RA & 26 & 22 & $\ldots$ & 103 & 3961 & 4682 \\
\hline TO & 108 & 92 & $\ldots$ & 767 & 7102 & 8337 \\
\hline NORDESTE & 14338 & 12186 & 53,3 & 40764 & 2843 & 3345 \\
\hline$A L$ & 1099 & 934 & 57,2 & 2260 & 2056 & 2420 \\
\hline BA & 2959 & 2515 & 51,9 & 11088 & 3747 & 4409 \\
\hline CE & 1884 & 1601 & 48,8 & 6149 & 3264 & 3841 \\
\hline MA & 726 & 617 & 48,3 & 4929 & 6789 & 7989 \\
\hline PB & 1764 & 1499 & 66,0 & 3153 & 1787 & 2103 \\
\hline PE & 3412 & 2900 & 50.7 & 7015 & 2056 & 2419 \\
\hline $\mathrm{PI}$ & 815 & 693 & 47,6 & 2553 & 3132 & 3684 \\
\hline RN & 1114 & 947 & 51,9 & 2244 & 2014 & 2370 \\
\hline SE & 565 & 480 & 62,1 & 1373 & 2430 & 2860 \\
\hline SUDESTE & 64048 & 54441 & 41.7 & 64400 & 1005 & 1183 \\
\hline ES & 1566 & 1331 & 50.1 & 2471 & 1578 & 1856 \\
\hline MG & 12760 & 10846 & 43,5 & 15884 & 1245 & 1464 \\
\hline RJ & 13662 & 11613 & 38,8 & 13725 & 1005 & 1182 \\
\hline SP & 36060 & 30651 & 41,8 & 32320 & 896 & 1054 \\
\hline SUL & 14619 & 12426 & 37,8 & 21718 & 1486 & 1748 \\
\hline PR & 5502 & 4677 & 37.5 & 8719 & 1585 & 1864 \\
\hline RS & 6752 & 5739 & 40,2 & 8812 & 1305 & 1535 \\
\hline SC & 2365 & 2010 & 31,9 & 4187 & 1770 & 2083 \\
\hline C.OESTE & 6262 & 5323 & 40,1 & 9375 & 1497 & 1761 \\
\hline $\mathrm{DF}$ & 1842 & 1566 & 43.0 & 1763 & 957 & 1126 \\
\hline GO & 2404 & 2043 & 38,9 & 3990 & 1660 & 1953 \\
\hline MS & 1235 & 1050 & 39.7 & 1735 & 1405 & 1652 \\
\hline MT & 781 & 664 & 37,4 & 1887 & 2416 & 2842 \\
\hline BRASIL & 101880 & 86598 & 42,9 & 144145 & 1415 & 1664 \\
\hline
\end{tabular}

NOTA $\because: 85 \%$ do total

Fontes: Bibllografias 61, 70, 201. 
TABELA 10

ABERTURA DE FACULDADES DE ODONTOLOGIA PÚBLICAS

E PAIVADAS SEGUNDO O PERIODO, NO BRASIL

\begin{tabular}{|c|c|c|c|c|c|c|}
\hline \multirow{3}{*}{ ANOS } & \multicolumn{4}{|c|}{ FACULDADES POR DEP. ADM. } & \multirow{3}{*}{$\begin{array}{l}\text { TOTAL } \\
\text { NÚMERO }\end{array}$} & \multirow{3}{*}{$\%$} \\
\hline & \multicolumn{3}{|c|}{ PÚBLICAS } & \multirow{2}{*}{ PRIVADAS } & & \\
\hline & FEDERAISE & ESTADUAIS & MUNICIPAIS & & & \\
\hline 1884 a 1900 & 3 & 1 & - & - & 4 & 4,94 \\
\hline 1901 a 1910 & 1 & - & - & - & 1 & 1,23 \\
\hline 1911 a 1920 & 7 & - & - & 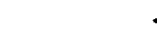 & 7 & 8,64 \\
\hline 1921 a 1930 & - & - & 2 & 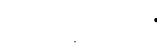 & 2 & 2,45 \\
\hline 1931 a 1940 & - & - & - & . & - & - \\
\hline 1941 a 1950 & 7 & - & - & & 8 & 9,88 \\
\hline 1951 a 1960 & 3 & 4 & - & & 10 & 12,35 \\
\hline 1961 a 1970 & 5 & 5 & - & & 13 & 16,05 \\
\hline 1971 a 1980 & 1 & - & 3 & 1 & 18 & 22.22 \\
\hline 1981 a $1990^{\circ}$ & - & 3 & 1 & 1 & 18 & 22,22 \\
\hline TOTAL & 27 & 15 & 4 & 3 & 81 & 100.00 \\
\hline
\end{tabular}

NOTA $:$ : Alo janeiro de 1990

Fontes: Bibliografias 25, 27, 48 . 
TABELA 11

NÜMERO DE CURSOS, CONCLUINTES E MATRICCULAS EM FACULDADES DE ODONTOLOGIA POR DEPENDENCIA ADMINISTRATIVA - BRASIL, 1988/90

\begin{tabular}{|c|c|c|c|c|}
\hline ANO & DEP.ADM. & CUASOS & $\begin{array}{c}\text { CONCLUINTES } \\
\text { ANO ANTERIOR }\end{array}$ & $\begin{array}{l}\text { MATRICULAS } \\
\text { EM 30/4 }\end{array}$ \\
\hline \multirow{6}{*}{1988} & TOTAL & 77 & 5315 & 26947 \\
\hline & PÚBLICO & 45 & 2945 & 14127 \\
\hline & FEDERAL & 27 & 1783 & 8718 \\
\hline & ESTADUAL & 15 & 922 & 4320 \\
\hline & MUNICIPAL & 3 & 240 & 1089 \\
\hline & PRIVADA & 32 & 2400 & 12820 \\
\hline \multirow{6}{*}{1989} & TOTAL & 79 & 5407 & 28362 \\
\hline & PÜBLICO & 46 & 2922 & 14212 \\
\hline & FEDERAL & 27 & 1750 & 8707 \\
\hline & ESTADUAL & 15 & 920 & 4335 \\
\hline & MUNICIPAL & 4 & 252 & 1170 \\
\hline & PRIVADA & 33 & 2485 & 14150 \\
\hline \multirow{6}{*}{1990} & TOTAL & $81^{\circ}$ & 5495 & 27949 \\
\hline & PÚBLICO & 46 & 2880 & 13080 \\
\hline & FEDERAL & 27 & 1698 & 8655 \\
\hline & ESTADUAL & 15 & 921 & 4380 \\
\hline & MUNICIPAL & 4 & 261 & 1204 \\
\hline & PRIVADA & 35 & 2615 & 14869 \\
\hline
\end{tabular}


TABELA 12

CONCLUINTES DE CURSOS DE ODONTOLOGIA -

BRASIL: DADOS 1954-90 E ESTIMATIVA

1991-2000

\begin{tabular}{|c|c|c|c|c|c|}
\hline ANO & NÚMERO & $\begin{array}{c}\text { INDICE } \\
(54=100)\end{array}$ & ANO & NÚMERO & $\begin{array}{c}\text { INDICE } \\
(54=100)\end{array}$ \\
\hline 1954 & 1278 & 100 & 78 & 4715 & 369 \\
\hline 55 & 1322 & 103 & 79 & 5114 & 400 \\
\hline 56 & 1351 & 106 & 80 & 5085 & 398 \\
\hline 57 & 1382 & 108 & 81 & 4895 & 383 \\
\hline 58 & 1294 & 101 & 82 & 4910 & 384 \\
\hline 59 & 1167 & 91 & 83 & 5095 & 399 \\
\hline 60 & 1363 & 107 & 84 & 5262 & 412 \\
\hline 61 & 1422 & 111 & 85 & 5313 & 416 \\
\hline 62 & 1367 & 107 & 86 & 5371 & 420 \\
\hline 63 & 1315 & 103 & 87 & 5345 & 418 \\
\hline 64 & 1214 & 95 & 88 & 5315 & 416 \\
\hline 65 & 1015 & 79 & 89 & 5407 & 423 \\
\hline 66 & 1226 & 96 & 90 & 5495 & 430 \\
\hline 67 & 1436 & 112 & 91 & 5895 & 461 \\
\hline 68 & 1621 & 127 & 92 & 6048 & 473 \\
\hline 69 & 1714 & 134 & 93 & 6200 & 485 \\
\hline 70 & 1605 & 126 & 94 & 6353 & 497 \\
\hline 71 & 1901 & 149 & 95 & 6506 & 509 \\
\hline 72 & 2153 & 168 & 96 & 6658 & 521 \\
\hline 73 & 2424 & 190 & 97 & 6811 & 533 \\
\hline 74 & 2942 & 230 & 98 & 6964 & 545 \\
\hline 75 & 2885 & 226 & 99 & 7117 & 557 \\
\hline 76 & 3891 & 304 & 2000 & 7269 & 569 \\
\hline 77 & 4163 & 326 & - & - & - \\
\hline
\end{tabular}

Fontes: Bibliogralias 24,25. 
: 5.2. Postos de Trabalho e Recursos Humanos no Setor público

Um importante estudo realizado pela Divisão Nacional de Saúde Bucal do Ministério da Saúde em conjunto com a Coordenadoria de Supervisão e Auditoria de Odontologia do INAMPS em 1989 fornece a base principal para a construção das Tabelas 13 e 15. Nesta última temos 0 número de postos de trabalho ocupados por CirurgiōesDentistas em instituições oficiais e para-oficiais, estado por estado. Os dados, sempre que necessário, foram complementados com informações provenientes do próprio estado ou dos bancos de dados do INAMPS. Os critérios utilizados $e$ as fontes especificas dos dados estão explicitados no Anexo I.

\section{:: $\quad$ 5.2.1. Serviços da Previdência Social}

A Tabela 13 resume os dados referentes ao total de CirurgióesDentistas em serviços próprios e credenciados (pessoas físicas), bem como o número de contratos firmados com pessoas jurídicas credenciadas, órgãos públicos, sindicatos, entidades filantrópicas, faculdades de odontologia.e hospitais universitários, abrangendo portanto $\circ$ universo de serviços prestados via previdência social $(46,47,116)$.

Nos serviços próprios estão computados os profissionais contratados e assalariados diretamente pelo INAMPS e que desempenham suas atividades em consultórios pertencentes a esta instituição. Os odontólogos credenciados atendem em seus consultórios particulares a pacientes encaminhados pelo INAMPS, obedecendo a padróes pré-determinados quanto aos serviços cobertos e preços (o pagamento dos serviços é feito ao final do mês pelo Instituto, contra a apresentação de relatório e fatura). Um sistema similar é aplicado em relação às empresas credenciadas (pessoas jurídicas), com a diferença de que neste caso é a empresa odontológica que contrata os dentistas, assumindo os encargos trabalhistas e os salários ou pró-labores de acordo com o tipo de relação de dependência estabelecida internamente: profissionais assalariados que atuam na empresa, "pool" de profissionais que atendem em seus próprios consultórios, etc.

Os órgãos públicos incluem desde a Fundação SESP que pertence ao Ministêrio da saúde até um vasto universo composto pelos serviços odontológicos das secretarias de saúde (e as vezes de Educação também) e de variadas Fundações dos estados e dos municípios. O INAMPS remunera os serviços até um certo limite de acordo com os recursos disponiveis e com a capacidade instalada de cada órgão, que por sua vez atende diretamente a população.

Na rubrica relativa aos Sindicatos, incluem-se tanto as entidades de trabalhadores quanto as patronais que atuam nas zonas urbana e rural. As Entidades Filantrópicas ou beneficentes, que não visam lucro como entidades (este conceito não se aplica aos profissionais que nelas trabalham, o que em parte explica porque muitos hospitais e organizações do gênero apresentam balanços deficitários enquanto seus médicos e odontólogos prosperam 
privadamente a olhos vistos)(14,147,180,230) de acordo com o estabelecido pela legislaçāo brasileira específica, atuam em forma similar ao das empresas credenciadas, embora a regra neste caso seja a da prestação direta de serviços e não a sua sub-contratação.

Finalmente, as Faculdades de Odontologia e os Hospitais Universitários contam com convênios especificos com a previdência que, na prática, lhes confere alguns privilégios por exemplo quanto à remuneração e à permissão do trabalho agregado de alunos.

Duas características devem ser destacadas no modelo previdenciário de prestação de assistência odontológica: a) não há um programa definido de cobertura populacional onde grupos de atendimento e metas a atingir estejam estabelecidos, limitando-se a determinar o que pode e não pode ser feito e ser pago; b) há um teto estabelecido para cada prestador e esta é a lei maior do "sistema". No fundo, cada prestador contratado, credenciado ou conveniado (estes termos tếm significado similar, variando de acordo com a figura jurídica do prestador sob contrato e com o tipo de serviços que podem ser prestados) precisa atingir o teto que lhe foi definido: se fizer a menos só recebe o que cobrou e se fizer a mais não recebe ou fica com un crédito para o mês seguinte e desde que não volte a ultrapassar seus limites. A possibilidade de fraudes é grande nessas modalidades pois os controles principais estão concentrados sobre a observância ou nâo dos tetos, o que significa a manutenção da viabilidade financeira do "sistema". Mesmo assim, em alguns casos o teto pode não ser aplicado, ou pelo menos pode ser expandido: é o caso dos convênios com sindicatos e 86 a 89 com os órgãos públicos, que em odontologia apresentam uma produção por prestador bastante superior à aceita para os profissionais credenciados, entidades filantrópicas e outros convênios, como se pode observar pela Tabela $14(118,119,120)$.

A implantação do pagamento por "procedimento" em substituição à remuneração por "unidade de serviço" (passou-se a pagar por uma cirurgia cardíaca ao invéz de ato por ato - anestesia, intervenção operatória, sutura, etc.), que tantas mudanças causou nas relaçes entre pagador e prestador na área médica, virtualmente não teve influência sobre a área odontológica. Aqui, as antigas "unidades de serviço" - restaurações, extraçōes, etc. - foram em sua maior parte simplesmente transformadas em "procedimentos", ao serem consideradas como indivisiveis.

Os serviços próprios, em 1989, estavam concentrados predominantemente na região sudeste $e$, aí, no Rio de Janeiro que por si só reunia 298 do total de odontólogos do quadro. Já entre os credenciados predominavam os gaúchos com larga margem sobre os demais, possivelmente como um reflexo do maior favorecimento neste particular ocorrido quando da gestão à testa da previdência de ministro proveniente do Rio Grande do Sul. Entretanto, a região Nordeste detinha proporcionalmente as maiores fatias no mercado de contratação de Sindicatos e de Entidades Filantrópicas, respectivamente com 32 e 398 do total de contratos com a previdência. 
Ao analisarmos a produção, através da Tabela 14, cabe ressaltar preliminarmente a inviabilidade de assumir conclusōes de conteúdo pelo simples exame desses números, considerando que ao nível local não há supervisão sobre a coleta e que os critérios de preenchimento são variáveis de acordo com cada prestador, estando fortemente sujeitos à influência de consideraçōes predominantemente não clínicas, ou seja, de cumprimento do teto financeiro mensal.

De toda maneira, as seguintes constatações surgem a partir da comparação entre os diversos prestadores quanto ao volume total de serviços no decênio:

a)- 0 número de consultas e de procedimentos cresceu significativamente até $1984 / 85$, mas a partir da implantação das mudanças na previdência em 86 começaram a decrescer atingindo em 1989 praticamente os mesmos patamares dos anos 1980/81;

b) - a rede pública, que no início da década responsabilizavase apenas por $1 / 4$ das consultas, chegou a $89 \mathrm{com}$ mais da metade do total, num extraordinário crescimento devido principalmente ao privilegiamento dos órgãos públicos (repetindo o que ocorreu na área ambulatorial médica), à redução da presença dos credenciados e dos sindicatos, acrescido da diminuição da oferta de serviços na segunda metade da década;

c) - os serviços próprios diminuiram sua representatividade de maneira gradual e constante, num fenômeno que só a contar de 86 pode em parte ser explicado pela transferência de profissionais para os órgãos públicos conveniados;

d) - as faculdades de odontologia deram um salto na sua participação relativa sobre os serviços previdenciários por volta de 1982, quando se concretizaram os convênios em que o INAMPS numa tentativa de apoia-las econômicamente passou a pagar atividades extra-muros. Diversas escolas instalaram clínicas para atendimento à população, beneficiando-se bastante com os novos recursos advindos da previdência (em geral o pessoal era pago pelas verbas da própria escola), embora não se disponha de informaçōes sobre possíveis impactos positivos dessa estratégia sobre a melhora dos níveis de saúde das comunidades abrangidas, o que reforça o conceito de que a ausência de programas claros de cobertura populacional e de prevenção termina por inutilizar ou descaracterizar muitos dos esforços e os gastos feitos;

e) - a diminuição da participação da rede privada, notadamente dos odontólogos credenciados e dos sindicatos que detém 0 maior volume de serviços nesse campo, aconteceu mais pela aplicação de tetos mais rígidos sobre a produção aceita e pelo não encaminhamento de tantos pacientes como antes aos consultórios particulares, do que pelo descredenciamento ou pelo rompimento de convênios. Como os orçamentos não aumentaram e como a política adotada foi de apoio à rede pública, os prestadores privados perderam gradativamente o interesse sobre uma instituição que já não tinha nem o poder nem os recursos dos anos sessenta e setenta; 
f) - em 1981 a previdência ainda oferecia no ano uma consulta odontológica para cada 3,5 brasileiros, mas em 1989 esta relação passou a ser de $1: 4,2$. E uma linha de assistência tradicionalmente tida como precária, que se viu encolhida e que ao final deixou ainda mais desassistidos os que a utilizavam ou dela dependiam por escolha pessoal ou por absoluta falta de opções, contribuindo com sua parcela para os fortes aumentos de gastos pessoais com atenção odontológica conforme análise feita no tópico 5.3 . 
TABELA 13

NÚMERO DE CIRURGIOES-DENTISTAS E NÜMERO DE CONTRATOS DE PRESTAÇĀO DE SERVIÇOS ODONTOLOGICOS DE ACORDO COM A REGIAO E O ESTADO' - INAMPS, 1989

\begin{tabular}{|c|c|c|c|c|c|c|c|c|}
\hline $\begin{array}{l}\text { REGIẢOI } \\
\text { ESTADO }\end{array}$ & $\begin{array}{l}\text { PRO- } \\
\text { PRIO }\end{array}$ & $\begin{array}{c}\text { CREDENC. } \\
\text { (pessoa } \\
\text { ilsica) }\end{array}$ & $\begin{array}{c}\text { CREDENC. } \\
\text { (pessoa } \\
\text { jurld.) }\end{array}$ & $\begin{array}{c}\text { ORGAOS } \\
\text { PÚBLI- } \\
\text { COS }\end{array}$ & $\begin{array}{l}\text { SINDI- } \\
\text { CATO }\end{array}$ & $\begin{array}{l}\text { ENTID. } \\
\text { FILAN- } \\
\text { TROP. } \\
\end{array}$ & $\begin{array}{c}\text { FAC. } \\
\text { DE } \\
\text { ODONT. }\end{array}$ & $\begin{array}{l}\text { HOSP. } \\
\text { UNIV. }\end{array}$ \\
\hline NORTE"* & 90 & 44 & 27 & 7 & 61 & 1 & 3 & 2 \\
\hline$A C$ & 4 & 12 & 0 & 0 & 1 & 0 & 0 & 0 \\
\hline$A M$ & 25 & 1 & 5 & 1 & 13 & 1 & 2 & 1 \\
\hline$P A$ & 53 & 31 & 22 & 6 & 47 & 0 & 1 & 1 \\
\hline RO & 8 & ... & ... & ... & $\cdots$ & ... & $\cdots$ & $\ldots$ \\
\hline NORDESTE & 728 & 1147 & 49 & 179 & 834 & 119 & 6 & 2 \\
\hline$A L$ & 141 & 177 & 0 & 1 & 130 & 0 & 0 & 0 \\
\hline BA & 84 & 192 & 13 & 24 & 238 & 29 & 1 & 0 \\
\hline CE & 88 & 158 & 14 & 124 & 151 & 57 & 1 & 0 \\
\hline MA & 42 & 58 & 2 & 0 & 71 & 0 & 0 & 0 \\
\hline PB & 107 & 51 & 3 & 0 & 23 & 3 & 0 & 1 \\
\hline$P E$ & 156 & 78 & 7 & 4 & 26 & 10 & 1 & 0 \\
\hline PI & 45 & 143 & 9 & 0 & 50 & 6 & 2 & 0 \\
\hline RN & 38 & 218 & 1 & 26 & 74 & 14 & 1 & 1 \\
\hline SE & 27 & 72 & 0 & 0 & 71 & 0 & 0 & 0 \\
\hline SUDESTE & 1203 & 1271 & 157 & 763 & 775 & 155 & 18 & 17 \\
\hline ES & 46 & 11 & 0 & 21 & 78 & 13 & 1 & 0 \\
\hline MG & 159 & 891 & 3 & 648 & 406 & 63 & 6 & 1 \\
\hline RJ & 734 & 163 & 34 & 53 & 109 & 32 & 10 & 9 \\
\hline SP & 264 & 206 & 120 & 41 & 182 & 47 & 1 & 7 \\
\hline SUL & 388 & 2066 & 28 & 333 & 762 & 11 & 6 & 3 \\
\hline PR & 84 & 328 & 6 & 281 & 226 & 4 & 5 & 0 \\
\hline RS & 152 & 1570 & 14 & 52 & 334 & 7 & 0 & 3 \\
\hline SC & 152 & 168 & 8 & 0 & 202 & 0 & 1 & 0 \\
\hline C.OESTE & 137 & 206 & 3 & 65 & 139 & 19 & 3 & 2 \\
\hline DF & 30 & 3 & 0 & 0 & 0 & 3 & 1 & 1 \\
\hline GO & 66 & 199 & 0 & 54 & 97 & 15 & 2 & 0 \\
\hline MS & 21 & 0 & 0 & 11 & 26 & 0 & 0 & 1 \\
\hline MT & 20 & 4 & 3 & 0 & 16 & 1 & 0 & 0 \\
\hline
\end{tabular}

\begin{tabular}{lllllllll} 
BRASIL & 2546 & 4734 & 264 & 1347 & 2571 & 305 & 36 & 26 \\
\hline
\end{tabular} NOTA ': Proprios a Pessoas Fisicas Credenciadas = número de protissionais

Demais = número de contratos ou convenios

-: Roraima incluida no Amazonas; Amapá no Pará e Tocantins em Goiás

Fontes: Bibliografias 46, 118 
TABELA 14

DISTRIBUIÇÃO PERCENTUAL DOS PROCEDIMENTOS E NÜMEROS

TOTAIS DE CONSULTAS E PROCEDIMENTOS ODONTOLOGICOS SEGUNDO O

PRESTADOR, NO PAIS - INAMPS, 1980 A 1989

\begin{tabular}{|c|c|c|c|c|c|c|c|c|c|c|}
\hline PRESTADOR & 1980 & 1981 & 1982 & 1983 & 1984 & 1985 & 1986 & 1987 & 1988 & 1989 \\
\hline IEDE PÚBLICA & 24,48 & 27,58 & 29,38 & 34,13 & 36,33 & 37,82 & 44,50 & 48,57 & 49,54 & 53,31 \\
\hline ZOPRIOS & 16,05 & 14,37 & 13,32 & .12 .39 & 10,96 & 10,15 & 8,70 & 7,76 & 6,38 & 6,40 \\
\hline ORG.GOVERN. & 7,58 & 12,19 & 14,65 & 20,16 & 23.90 & 26,54 & 34,81 & 39,48 & 41,68 & 44,43 \\
\hline UNIVERSID. & 0,85 & 1,02 & 1.41 & 1,58 & 1,47 & 1.13 & 0,99 & 1,33 & 1,48 & 1.48 \\
\hline REDE PRIVADA & 75,52 & 72,42 & 70,62 & 65,87 & 63,67 & 62,18 & 55,50 & 51,43 & 50,46 & 47,69 \\
\hline ONTRATADA & 24,08 & 23.50 & 21.99 & 17,70 & 16,90 & 16,03 & 15,42 & 15,77 & 16,18 & 15,60 \\
\hline ENT.FILANTR. & 4,61 & 3.96 & 3,90 & 3,68 & 3,48 & 3.14 & 1,13 & 1,32 & 1,61 & 2,42 \\
\hline SINDICATOS & 43.11 & 41,00 & 41,40 & 41,83 & 40,74 & 40,68 & 35,83 & 32,00 & 30,66 & 28,71 \\
\hline OUTROS CONV & 3,72 & 3,96 & 3,33 & 2,66 & 2,55 & 2,33 & 3,12 & 2,34 & 2,01 & 0,96 \\
\hline TOTAL & 100 & 100 & 100 & 100 & 100 & 100 & 100 & 100 & 100 & 100 \\
\hline $\begin{array}{r}\text { CONSULTAS } \\
\text { (mil) }\end{array}$ & 31517 & 35745 & 37051 & 38682 & 40649 & 39953 & 35089 & 35204 & 34614 & 34224 \\
\hline $\begin{array}{r}\text { PAOCEDIM. } \\
\text { (mil) }\end{array}$ & 56421 & 63990 & 66322 & 67883 & 72045 & 69879 & 61410 & 64250 & 67593 & 57571 \\
\hline
\end{tabular}

Fontes: Bibliogratias 119, 120. 


\section{:: 5.2.2. Postos de trabalho ocupados em Odontologia}

A Tabela 15 procura contabilizar o total aproximado de postos de trabalho por região e estado, em 1989, ocupados por CirurgiõesDentistas segundo a instituição empregadora ou responsável e o número de horas semanais contratadas, em instituiçōes do setor público e em entidades para-oficiais como por exemplo o SESI e o SESC $(46,47,85,118,119,140,153,154,155,169,183,201,214,217,223)$.

É evidente que não se pode falar em número de odontólogos e sim de postos de trabalho, uma vez que um profissional pode ocupar dois ou mais postos.

Os critérios utilizados estão descritos no Anexo I.

Os dados estão organizados em torno de oito grandes grupos institucionais: 1) INAMPS, 2) Fundação SESP, 3) Secretarias de Saúde e de Educação, 4) Prefeituras Municipais, 5) Outras (SESC, SESI, etc.), 6) Faculdades de Odontologia onde há profissionais prestando serviços nos convênios com a previdência social, 7) Sindicatos patronais e de trabalhadores e, finalmente, 8) os Credenciados pelo INAMPS.

No total, estima-se que em 1989 havia 40581 postos de trabalho ocupados por Cirurgiōes-Dentistas no país, distribuidos regionalmente com preferência para as regiōes sudeste (43\%), sul e nordeste (em torno de $47 \%$ ambas), e menor ênfase para as regiōes Centro Oeste $(78)$ e Norte (38).

Considerando-se os profissionais teoricamente em atividade, tinhamos uma relação global de aproximadamente um emprego para cada dois profissionais $(1: 2,13)$, com uma variação forte entre os limites de $1: 3,1$ na região sudeste para $1: 1,3$ no sul e $1: 1,2$ no Nordeste $(1: 1,6$ no Norte e $1: 2,0$ no Centro-Oeste).

As Prefeituras Municipais respondem pela maior oferta de postos de trabalho nas regiōes sudeste e sul, ao passo que este papel cabe às instituiçōes estaduais nas demais. Diferenças importantes podem ser observadas no que respeita à presença das municipalidades na prestação de serviços odontológicos à população, com um forte destaque para os estados econômicamente mais fortes ou com maior tradição local ou comunitária, como é o caso de santa Catarina, Paraná, São Paulo e Minas Gerais.

No conjunto, estima-se que semanalmente teriamos no país a seguinte situação em termos de horas de trabalho disponiveis:

- 31326 postos de 20 horas $=626520$ hs ou 678 ;

- 6447 postos de 30 horas $=193410$ hs. ou $218, \mathrm{e}$

- 2794 postos de 40 horas $=111760$ hs ou 128 do total.

Assim, teriamos cerca de 931690 horas de trabalho dedicadas institucionalmente à atenção odontológica no Brasil, por 
semana (Gráfico III), correspondendo a aproximadamente $27 \%$ do tempo total disponivel dos 86598 odontólogos em atividade no país (estimativa com base em 40 hs. disponíveis por profissional por semana).

Esta situação não é compatível com aquela retratada no Capítulo 4.2, onde se viu que em 1989 nada menos que 278 das pessoas ocupadas ganhavam apenas um salário mínimo. Se considerarmos que um trabalhador que ganhe no máximo dois salários mínimos não tem condições de frequentar uma clínica particular de odontologia por absoluta incapacidade de remunerar os serviços de que necessita aos preços que the seriam cobrados, vemos que aproximadamente $2 / 3$ dos trabalhadores não tem no Brasil condiçōes reais de serem atendidos em clínicas privadas, nas quais concentrase quase $3 / 4$ do tempo de trabalho ofertado pelos CirurgioesDentistas brasileiros.

Torna-se evidente, portanto, que o modelo de prestação de cuidados odontológicos adotado de forma predominante no país é incorreto pois na prática a grande maioria das pessoas a êle não tem possibilidade de acesso. Este não é, obviamente, um problema especifico da área odontológica, pois afeta de maneira praticamente generalizada as demais profissōes, todas elas inseridas no contexto da crise brasileira; não obstante, nela agudiza-se, inclusive em relação à prática médica básica, pois nesta a oferta de serviços públicos e para-oficiais é bem mais ampla.

Do total de horas semanais disponiveis para prestação de cuidados odontológicos sem custo direto à população, mais da metade - 528 - está concentrado nas clínicas das secretarias de Saúde/Educação $(28,78)$ e das municipalidades $(23,58)$, seguindo-se pela ordem: 16,58 em outras instituiçōes; 11,48 em profissionais credenciados em suas próprias clínicas; $11 \%$ em Sindicatos; 8,28 nos serviços próprios da previdência social e 0,78 na Fundação SESP.

Cada um desses prestadores de serviços tem suas regras de conduta, suas prioridades e seus modelos de trabalho, constituindo dentro do setor direta ou indiretamente dependente de recursos públicos o que se poderia denominar de um "não sistema". Até mesmo as divisões por áreas de influência ou de cobertura são por vezes obscuras, fazendo com que uma mesma pessoa possa ter direito a utilizar diversos serviços enquanto que muitas outras só tem uma possibilidade ou até mesmo nenhuma. Há empresas, por exemplo, que oferecem serviços de saúde como um salário indireto a seeus empregados e as vezes às suas familias. Mas os seus beneficiados continuam tendo acesso tanto aos serviços públicos ofertados pelas Secretarias de Saúde ou Educação de Estados e Municípios, quanto aos das entidades para-oficiais da sua área laboral (p.ex. SESI aos industriários, SESC aos comerciários), provocando múltipla cobertura de serviços para um mesmo indivíduo. Como a oferta global é limitada, muitos e muitos ficam sem qualquer tipo de assistência, provocando desequilíbrios e desigualdadees fortes dentro do setor e particularmente no seio de cada comunidade. 
- número de horas contratadas, no caso brasileiro, dificilmente corresponde ao número de horas efetivamente trabalhadas, sendo comuns as instituiçōes onde vigora a extranha regra de que uma vez atendidos todos os pacientes marcados 0 profissional pode ir embora para casa ou para suas outras atividades. Nesses casos, os atendimentos são muitas vezes prestados de maneira impessoal e com muita rapidez, numa prática que é ainda mais comum entre os médicos. Chegar mais tarde e sair mais cedo constitui costume relativamente frequente, $e$ um profissional poderá até mesmo receber pressões de colegas menos assíduos se decidir-se a cumprir com precisāo seus horários de trabalho e a ocupar-se integralmente no tempo contratado com o efetivo atendimento da população que dele necessita; sob argumentos que vão desde os baixos salários que não justificariam tanto empenho, até 0 apelo a uma discutível "ética profissional" pela qual estariam sendo "prejudicados" os colegas que chegam mais tarde, saem mais cedo, etc. Instituições nas quais é necessário o cumprimento dos horários acordados nos contratos de trabalho, podem ser consideradas como exceções à regra no Brasil. Assim, na prática - tempo total disponivel para efetivo atendimento de pacientes em instituições oficiais e para-oficiais é inferior ao tempo teoricamente contratado.

Não existem referências na literatura sobre quanto tempo é retirado da população que necessita atendimento por esta via, mas uma estimativa que aponte uma proporção entre 20 e $30 \%$ do tempo total como perdido certamente não estaria longe da realidade. 


\section{GRÁFICO III \\ OFERTA DE SERVIÇOS ODONTOLÓGICOS:HORAS SEMANAIS POR INSTITUIÇÃO BRASIL, 1989}

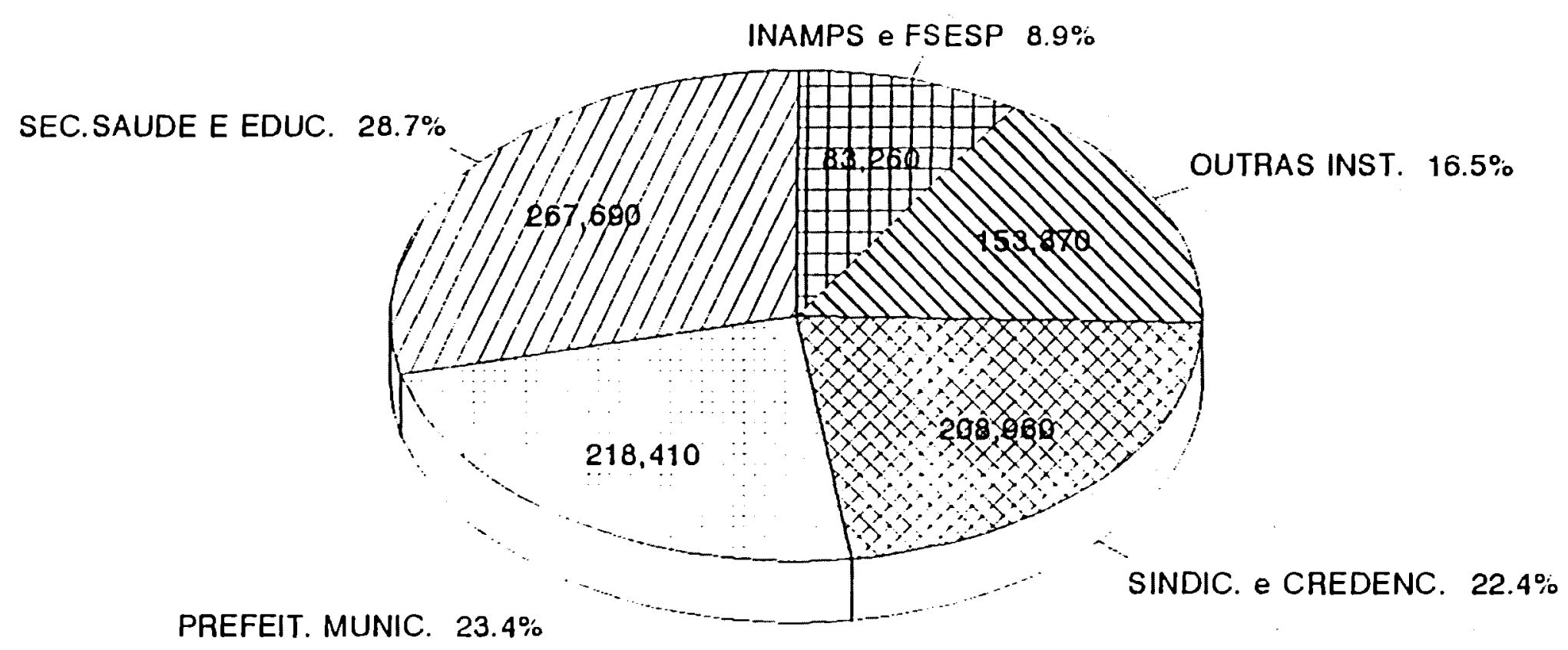


TABELA 15

POSTOS DE TRABALHO OCUPADOS POR CIRURGIOES-DENTISTAS EM INSTITUICOES PÚBLICAS, PARA-OFICIAIS, CREDENCIAMENTOSE EM CONVENIOS COM O INAMPS, SEGUNDO AS HORAS OCUPADAS NA SEMANA. BRASIL, 1989.

\begin{tabular}{|c|c|c|c|c|c|c|c|c|c|c|c|c|c|}
\hline REGIĀOI & INAMPS & F.SESP & & SOSE & & & P.MUN & VIC. & OUTRAS & INST. & SINDIC. & CREDENC. & TOTAL \\
\hline ESTADO & $30 \mathrm{Hs}$ & $40 \mathrm{Hs}$ & $20 \mathrm{hS}$ & $30 \mathrm{Hs}$ & $40 \mathrm{Hs}$ & $20 \mathrm{Hs}$ & $30 \mathrm{Hs}$ & $40 \mathrm{Hs}$ & $20 \mathrm{Hs}$ & $30 \mathrm{Hs}$ & $20 \mathrm{Hs}$ & $20 \mathrm{Hs}$ & \\
\hline NORTE' & 90 & 39 & 347 & 105 & 158 & 127 & 36 & 8 & 150 & 92 & 122 & 103 & 1377 \\
\hline AM & 29 & 14 & 283 & 0 & 0 & 90 & 0 & 4 & 97 & 18 & 28 & 24 & 587 \\
\hline PA & 53 & 20 & 0 & 105 & 72 & 13 & 36 & 0 & 37 & 66 & 94 & 79 & 575 \\
\hline RO & 8 & 5 & 64 & 0 & 86 & 24 & 0 & 4 & 16 & 8 & 0 & 0 & 215 \\
\hline NORDESTE & 728 & 90 & 1944 & 1386 & 269 & 884 & 123 & 55 & 1315 & 140 & 1668 & 1252 & 9862 \\
\hline AL & 141 & 9 & 159 & 0 & 16 & 17 & 0 & 0 & 39 & 4 & 260 & 177 & 822 \\
\hline$B A$ & 84 & 20 & 0 & 521 & 0 & 123 & 8 & 14 & 201 & 22 & 476 & 220 & 1689 \\
\hline CE & 88 & 10 & 633 & 0 & 0 & 92 & 0 & 0 & 243 & 26 & 302 & 188 & 1582 \\
\hline MA & 42 & 7 & 23 & 82 & 54 & 44 & 0 & 0 & 90 & 10 & 142 & 62 & 556 \\
\hline PB & 107 & 10 & 628 & 0 & 0 & 160 & 15 & 0 & 76 & 8 & 46 & 58 & 1108 \\
\hline PE & 156 & 11 & 0 & 570 & 0 & 143 & 10 & 6 & 356 & 39 & 52 & 93 & 1444 \\
\hline PI & 45 & 8 & 368 & 0 & 0 & 151 & 0 & 0 & 101 & 10 & 100 & 162 & 945 \\
\hline RN & 38 & 7 & 133 & 12 & 199 & 134 & 0 & 35 & 151 & 15 & 148 & 220 & 1092 \\
\hline SE & 27 & 8 & 0 & 201 & 0 & 20 & 90 & 0 & 58 & 6 & 142 & 72 & 624 \\
\hline SUDESTE & 1203 & 21 & 2244 & 667 & 1100 & 5400 & 215 & 346 & 2409 & 538 & 1550 & 1612 & 17305 \\
\hline ES & 46 & 0 & 55 & 0 & 0 & 94 & 0 & 0 & 205 & 50 & 156 & 11 & 617 \\
\hline MG & 159 & 16 & 722 & 100 & 81 & 1214 & 53 & 67 & 721 & 167 & 812 & 898 & 5010 \\
\hline RJ & 734 & 5 & 800 & 0 & 0 & 629 & 0 & 9 & 656 & 129 & 218 & 237 & 3417 \\
\hline$S P$ & 264 & 0 & 667 & 567 & 1019 & 3463 & 162 & 270 & 827 & 192 & 364 & 466 & 8261 \\
\hline SUL & 388 & 13 & 576 & 44 & 313 & 2530 & 126 & 76 & 1325 & 337 & 1524 & 2126 & 9384 \\
\hline PR & 84 & 1 & 72 & 0 & 57 & 1386 & 0 & 8 & 501 & 116 & 452 & 341 & 3018 \\
\hline RS & 152 & 10 & 254 & 43 & 218 & 664 & 74 & 0 & 594 & 148 & 668 & 1600 & 4425 \\
\hline Sc & 152 & 2 & 250 & 1 & 38 & 480 & 52 & 68 & 230 & 73 & 404 & 185 & 1941 \\
\hline C.OESTE & 137 & 9 & 700 & 3 & 293 & 226 & 17 & 4 & 701 & 72 & 278 & 213 & 2653 \\
\hline DF & 30 & 0 & 196 & 0 & 0 & 0 & 0 & 0 & 278 & 0 & 0 & 3 & 507 \\
\hline GO & 66 & 3 & 386 & 3 & 9 & 104 & 0 & 0 & 216 & 0 & 194 & 199 & 1180 \\
\hline MS & 21 & 4 & 27 & 0 & 263 & 62 & 12 & 4 & 87 & 68 & 52 & 0 & 600 \\
\hline MT & 20 & 2 & 91 & 0 & 21 & 60 & 5 & 0 & 120 & 4 & 32 & 11 & 366 \\
\hline BRASIL & 2546 & 172 & 5436 & 2157 & 2073 & 10097 & 541 & 547 & 6966 & 1441 & 5142 & 5306 & 40581 \\
\hline
\end{tabular}

NOTA ": Acre $\theta$ Roraima estảo incluidos no Amazonas; Amapá no Pará $\theta$ Tocantins em Goiás.

Fontes: Bibllografias 46,61,85,106,118,146,153,155. $169,175,201,214,217,222$. 


\section{:: 5.2.3. Recursos Humanos de Nível Técnico e Auxiliar}

As informações sobre o número de Técnicos de Higiene Dental (THD) e de Atendentes de Consultório Dentário (ACD) existente nos diversos estados são bastante precárias, principalmente sobre a última categoria e ainda sobre a variada gama de auxiliares sem formação especifica que comumente trabalha nas clinicas odontológicas.

Segundo os dados obtidos através dos estudos da Divisão nacional de Saúde Bucal, do INAMPS e de alguns estados para o ano de 1989, cerca de 1320 THDs estavam em atividade no país, assim distribuidos: 73 na região Norte, 72 no Nordeste, 300 no Sudeste, 495 no sul e 380 no centro-Oeste. Sua presença era efetiva principalmente nos estados do Pará, Rondônia, Bahia, Piaui, Maranhão, Sergipe, Goiás, Mato Grosso, Mato Grosso do Sul, Rio de Janeiro, Minas Gerais, São Paulo, Paraná e Distrito federal, com os maiores contingentes concentrados na capital da República, no Paraná, Rio de Janeiro, S.Paulo, Goiás, Pará e Mato Grosso do Sul(47,119,146,154,155,217,223). Uma instituição - o serviço Social da Indústria - conta com um programa de âmbito nacional para treinamento e contratação de THDs em suas unidades(218,219).

Apesar de que as profissões de THD e de ACD tenham sido oficialmente instituidas em 1975 pelo Ministério da Eduaação, sua expansão tem sido muito lenta dada a resistência da classe dos Cirurgiões-Dentistas, ciosa da reserva de mercado de que é detentora. As maiores barreiras na década de oitenta foram levantadas em São Paulo, onde entidades representativas dos odontólogos mostraram-se ativamente corporativistas e conservadoras a respeito da incorporação de pessoal de nível técnico à força de trabalho profissional $(67,79,179,180)$.

Aonde as Técnicas de Higiene Dental (em geral sāo do sexo feminino) vêm atuando, os resultados têm sido inteiramente satisfatórios tanto em termos de aumento de produtividade, quanto de redução de custos e aceitação por parte dos pacientes e das comunidades $(33,46,47,136,140,155,169,171,203,207,214,216,223)$. .

- trabalho preventivo tem sido muito favorecido pela atuação do pessoal de nível técnico e auxiliar (49,51,207).

\section{: 5.3. Capacidade Instalada do Setor Público}

Desde que a linha de produção e utilização de equipamentos odontológicos "simplificados" (tecnológicamente apropriados) surgiu em Brasilia por volta do ano de 1976, gradativamente o setor público e outras instituições (o SESC do Distrito Federal foi pioneiro neste campo) adotaram este modelo levando-o a consolidarse a nivel nacional.

As clinicas modulares que combinam o trabalho de CirurgiōesDentistas, THDs e outros auxiliares, embora ainda representem uma fatia pequena do total de equipamentos instalados na área 
institucional, podem ser vistas na grande maioria dos estados brasileiros.

A Tabela 16, que apresenta o total de equipos odontológicos existente nas clínicas do setor público e das entidades paraoficiais com base no estudo da DNSB e do INAMPS, deve ser encarada como uma aproximação parcial e não necessariamente completa da realidade, pois para algumas instituições como Prefeituras de cidades do interior p.ex. não foi possivel coletar informações. Nos casos de São Paulo, Rio Grande do Sul e Santa Catarina o número de equipamentos foi estimado em função da quantidade de postos de trabalho(47,118).

Para o total de 20477 equipos anotados como sendo aproximadamente a capacidade instalada no âmbito institucional, 1/5 localizava-se em São Paulo e $2 / 5$ na região Sudeste. 
TABELA 16

NÜMERO ESTIMADO DE EQUIPOS ODONTOLOGICOS

NA ÁREA INSTITUCIONAL, POR ESTADO, 1989.

\begin{tabular}{|c|c|c|c|}
\hline $\begin{array}{l}\text { ESTADO } \\
\text { E REGIĀO }\end{array}$ & $\begin{array}{l}\text { INAMPS } \\
\text { (Próprios) }\end{array}$ & $\begin{array}{c}\text { OUTRAS INST. PÚBL. } \\
\text { E PARA-OFICIAIS }\end{array}$ & TOTAL \\
\hline NORTE & 52 & 639 & 691 \\
\hline$A C$ & $\ldots$ & $\ldots$ & $\ldots$ \\
\hline$A M$ & 17 & 335 & 352 \\
\hline AP & - & 29 & 29 \\
\hline PA & 29 & 152 & 181 \\
\hline RO & - & 92 & 92 \\
\hline RR & - & 31 & 31 \\
\hline NORDESTE & 326 & 4175 & 4501 \\
\hline AL & 35 & 193 & 228 \\
\hline BA & 47 & 593 & 640 \\
\hline$C E$ & 45 & 517 & 562 \\
\hline$M A$ & 10 & 454 & 464 \\
\hline PB & 44 & 590 & 634 \\
\hline PE & 79 & 755 & 834 \\
\hline PI & 23 & 410 & 433 \\
\hline RN & 20 & 353 & 373 \\
\hline SE & 23 & 310 & 333 \\
\hline SUDESTE & 541 & 8025 & 8566 \\
\hline ES & 18 & 215 & 233 \\
\hline MG & 112 & 2310 & 2422 \\
\hline RJ & 246 & 1300 & 1546 \\
\hline SP & 165 & 4200 & 4365 \\
\hline SUL & 241 & 3763 & 4004 \\
\hline PR & 53 & 1345 & 1398 \\
\hline RS & 86 & 1608 & 1694 \\
\hline $\mathrm{SC}$ & 102 & 810 & 912 \\
\hline C.OESTE & 146 & 1329 & 1475 \\
\hline DF & 19 & 350 & 369 \\
\hline GO & 92 & 476 & 568 \\
\hline MS & 14 & 320 & 334 \\
\hline MT & 21 & 183 & 204 \\
\hline BRASIL & 1306 & 17931 & 19237 \\
\hline
\end{tabular}




\section{GASTOS COM SAÚDE}

No Brasil, o setor saúde tem pouca tradição no trabalho com os aspectos relacionados ao financiamento dos seus serviços, tanto que foi só a partir da segunda metade da década de setenta que o tema começou a ganhar algum destaque nas discussões promovidas pela área pública. $\mathrm{Na}$. VIII Conferência de Saúde(66) o tema financiamento chegou a ser incluido como um dos tópicos principais de análise, consolidando $\circ$ seu gradativo avanço em termos das prioridades internas da área. Atualmente, as informaçōes disponiveis nas áreas oficiais ainda são restritas e englobam, com maior precisão, os gastos federais aí se incluindo o ator principal que é a previdência social através do INAMPS.

Recentemente a Fundação IBGE deu a conhecer os resultados da Pesquisa de Orçamentos Familiares(107) realizada nas Regiōes Metropolitanas (R.M.) de Belém, Recife, Fortaleza, Salvador, Belo Horizonte, Rio de Janeiro, São Paulo, Curitiba e Porto Alegre, além das cidades de Brasilia e Goiânia, fornecendo dados sobre despesas familiares com saúde distribuidas segundo os rendimentos em Pisos Salariais (P.S.).

Com base nesses estudos, combinados com informaçōes disponiveis na literatura $(30,44,113,114,147,148,149,202,231)$ e na Pesquisa Nacional por Amostras de Domicílio de maior atualidade (109) quanto às estratificações populacionais por classes de renda, torna-se possível compor um quadro aproximado dos gastos institucionais e pessoais com saúde geral e em particular com saúde bucal no Brasil, por regiões e para o ano de 1989.

Este capitulo representa um esforço no sentido de produzir este quadro global dos dispêndios em saúde, mesmo reconhecendo não ser possivel desenvolver um processo de exatidões matemáticas em um universo tão vasto como é o setor saúde brasileiro.

No Anexo II estão descritos os critérios e inferências adotados para as estimativas dos gastos pessoais e no Anexo III para os gastos institucionais.

Calcula-se que no ano de 1989 a partir de todas as fontes, públicas e privadas, o Brasil despendeu em torno de 22,9 bilhöes de dólares com saúde, dos quais 2,4 bilhōes em cuidados odontológicos, - que corresponde a uma despesa per capita de 158,80 e de 16,60 dólares respectivamente.

Estes números ao serem comparados com os dados da PNAD de 1981 revelam um significativo crescimento no volume total de gastos com saúde, tanto públicos quanto privados. Naquele ano as despesas totais com saúde alcançaram o montante de cerca de US\$13,0 bilhōes, correspondendo à área de saúde bucal em torno de 557,2 milhões de dólares(179). Este é um indicador que de um lado pode ser interpretado como a concretização do caráter compensatório que cabe ao setor saúde durante os períodos de crise econômica e, de outro, como um reflexo da maior capacidade de influência do "marketing" privado que efetivamente conseguiu vender mais serviços em plena 
fase recessiva, expandindo principalmente a linha de captação de recursos via seguros-saúde.

No âmbito específico da odontologia constatou-se um crescimento relativo superior ao verificado nos gastos globais com saúde, destacando-se o forte avanço dos gastos pessoais com tratamento clínico como consequência provável da manutenção de níveis muito elevados de doenças bucais e da ainda insuficiente e pouco efetiva rede de serviços públicos.

\section{: 6.1. Gastos Pessoais em Saúde Geral}

Os gastos anuais das familias, em dólares, nas nove R.M., em Brasilia e em Goiânia, com saúde geral e com "tratamento dentário", estratificados segundo os rendimentos em P.S., estão na Tabela $17(107)$.

Nas três R.M. nordestinas situam-se os mais reduzidos padrões de gastos, destacando-se no polo oposto as duas capitais estudadas na região Centro Oeste e as R.M. de São Paulo, Curitiba e Porto Alegre.

De maneira geral, as despesas são maiores nas faixas mais altas de renda, fenômeno que se repete quando se observa a representatividade dos gastos com odontologia em relação ao total em saúde.

Os extremos, segundo a Tabela 17, situam-se na R.M. de Recife onde uma familia destina em média 279 dólares ao ano para atendimento em saúde e 20 dólares para cuidados dentários, e na cidade de Goiânia onde essas cifras são respectivamente de 626 e de 130,5 dólares.

A menor participação proporcional das despesas com odontologia verifica-se na faixa de mais de 3 até 5 P.S. em Belém com apenas 1,61\%, embora vários outros grupos de baixa renda (à exceção de Brasilia e da R.M. de Belo Horizonte) apresentem percentuais semelhantes em todo o país.

De acordo com a Tabela 18 , estima-se em US\$ 10,7 bilhões de dólares o volume total de dispêndios pessoais com saúde no país para $O$ ano de $1989(107,109 ; 127,128,231)$. Cerca da metade do movimento é feito na região sudeste $(55,68)$, concentrando-se aproximadamente $1 / 5$ na região sul (208), outro $1 / 5$ nas regiōes nordeste $(12,68)$ e centro-oeste $(8,28)$ e o restante na região norte $(3,6 \%)$.

Em torno de 53\% dos gastos ocorrem nas Regiões Metropolitans, $37 \%$ nas demais cidades e $10 \%$ na zona rural, o que corresponde às relações observadas na PNAD/88(109) quanto à apropriação de renda.

- gasto per capita é semelhante nas regiōes sudeste, sul e centro-oeste onde varia de $93:$ a 99 dólares, mas cai significativamente no nordeste onde é de apenas 33 dólares em média e no norte onde não chega a 49 dólares. Relativamente, as cifras mais elevadas encontram-se nas capitais da região centro-oeste e as 
mais infimas na zona rural nordestina onde cada habitante despende ao ano somente 17 dólares com saúde. A média nacional para a zona rural não chega a 29 dólares por pessoa.

Quanto à distribuição para o volume global de despesas, temos: Medicamentos US\$ 3,52 bilhões ou 32,88 ; Tratamento Dentário US\$ 1,68 bilhão ou $15,6 \%$; Seguro-Saúde US\$ 1,17 bilhão ou 10,98 ; Consulta Médica US\$ 800 milhões ou 7,48 ; Óculos e Lentes US\$ 610 milhões ou 5,78 ; Hospitalização US $\$ 460$ milhões ou 4,38 e Outros Gastos US\$ 2,5 bilhöes ou 23,3\%. Cinco pontos podem aqui ser destacados:

- a) o volume relativamente alto dos dispêndios totais, em torno de US\$ 10,7 bilhões, que supera bastante estimativas anteriores e as cifras contabilizadas em 1981;

- b) a destacada representatividade das despesas com medicamentos que atinge cerca de $1 / 3$ do total;

-c) a importância que assumem em cada familia e para cada pessoa as despesas com cuidados odontológicos, os quais por si só consomem 15,68 dos recursos destinados à saúde;

-d) a forte expansão do ramo de seguro-saúde, que ao início da década sequer aparecia nas estatísticas dada sua pequena relevância. Esta, aliás, parece ser a explicação mais plausivel principalmente para a pequena participação dos gastos com hospitalilzação, os quais estariam sendo absorvidos na conta do seguro-saúde. Cabe lembrar que é exatamente no campo das internações hospitalares e das consultas médicas básicas que a presença do setor público direto e do INAMPS em suas diversas modalidades de prestação de serviços à população se faz notar com maior força, fazendo com que as pessoas efetivamente tenham menores despesas com essas ações;

-e) a presença significativa do item "outros gastos", respondendo por cerca de 238 do total, e que reune uma vasta gama de serviços médicos e para-médicos formais ou não, por exemplo nas áreas de fisioterapia, reabilitação, estética, entre outras. 
TABELA 17

GASTOS ANUAIS FAMILIARES COM SAÚDE E COM TAATAMENTO

DENTARIO SEGUNDO O NIVEL DE RENDIMENTOS, NAS REGIOES

METROPOLTTANAS, BRASILIIA E GOIÂNIA

(em dolares)

\begin{tabular}{|c|c|c|c|c|c|c|c|c|c|c|c|c|}
\hline \multirow[t]{2}{*}{ RM/CIDADE } & \multirow{2}{*}{$\begin{array}{l}\text { TIPO DE } \\
\text { GASTO }\end{array}$} & \multirow[t]{2}{*}{ TOTAL } & \multicolumn{10}{|c|}{ RENDIMENTOS FAMILIARES POR PISOS SALARIAIS } \\
\hline & & & ATE 2 & +2 a 3 & $+3 a 5$ & +5 a 6 & $+6 \mathrm{a} 8$ & +8 a 10 & +10 a 15 & +15 a 20 & +20 a 301 & $+\mathrm{de} 30$ \\
\hline & Saúde & 408,48 & 80,89 & 93,47 & 167,84 & 192.78 & 243,11 & 328,27 & 432,53 & 548,24 & 905,05 & 1460.26 \\
\hline \multirow[t]{3}{*}{ BELÉM } & Trat.Dent.: & 42,69 & 2,47 & 7,19 & 2,70 & 11,46 & 13,93 & 35,28 & 21,57 & 81.79 & 114,59 & 204,69 \\
\hline & $\%$ & 10,45 & 3,05 & 7,69 & 1,61 & 5,94 & 5,73 & 10,75 & 4,99 & 14,92 & 12,66 & 14,02 \\
\hline & Saúde & 289,85 & 34,83 & 55,05 & 97.07 & 129.65 & 208,51 & 214,58 & 466,68 & 485,78 & 628,46 & 1496,43 \\
\hline \multirow[t]{3}{*}{ FORTALEZA } & Trat.Dent: & 33,93 & 1,12 & 1,57 & 3,15 & 8,31 & 24,72 & 19,32 & 42,92 & 61,12 & 66.06 & 235,47 \\
\hline & $\%$ & 11,71 & 3,32 & 2,85 & 3,24 & 6,41 & 11,85 & 9,00 & 9.20 & 12,58 & 10,51 & 15,73 \\
\hline & Saúdo & 279,06 & 48.53 & 63.36 & 99.31 & 152,56 & 189,86 & 228.96 & 319,06 & 650.93 & 691,82 & 1268,82 \\
\hline \multirow[t]{3}{*}{ AECIFE } & Trat.Dent.: & 20,22 & 4,27 & 1,35 & 2,47 & 12.81 & 5,39 & 17,53 & 21,12 & 73,25 & 93.92 & 76,17 \\
\hline & $\%$ & 7,25 & 8,80 & 2,13 & 2,49 & 8,40 & 2,84 & 7,66 & 6,62 & 11,25 & 13,58 & 6.00 \\
\hline & Saũde & 300.63 & 64,04 & 93,70 & 115,27 & 129,42 & 186,72 & 224,69 & 257,04 & 383,10 & 473,65 & 1372,85 \\
\hline \multirow[t]{3}{*}{ SALVADOR } & Trat.Dent.: & 39,99 & 1,57 & 2,25 & 9,44 & 5,17 & 6,52 & 53.48 & 17.08 & 57,52 & 75.27 & 235,02 \\
\hline & $\%$ & 13,30 & 2,45 & 2,40 & 8.19 & 3.99 & 3,49 & 23,80 & 6,64 & 15,01 & 15,89 & 17,12 \\
\hline & Saúde & 409,16 & 90,55 & 124,70 & 188,74 & 164,92 & 241,09 & 353,21 & 328,27 & 466,90 & 999,64 & 1530,14 \\
\hline \multirow[t]{3}{*}{ B.HORIZONTE } & Trat.Dent.: & 92,80 & 14,83 & 16,63 & 33,03 & 22,02 & 51,23 & 141,78 & 74,15 & 101,78 & 222,22 & 355,91 \\
\hline & $\%$ & 22,68 & 16,38 & 13,34 & 17,50 & 13.35 & 21,25 & 40,14 & 22,59 & 21,80 & 22,23 & 23,26 \\
\hline & Saúde & 340,63 & 65,16 & 73,02 & 138,18 & 194,58 & 188,96 & 276,37 & 312,32 & 484,66 & 586.89 & 1362,52 \\
\hline \multirow[t]{3}{*}{ A.JANEIRO } & Trat.Dent.: & 50.33 & 1,80 & 2,47 & 19,77 & 13,26 & 26,74 & 25,84 & 48.98 & 97.74 & 175,48 & 151,89 \\
\hline & $\%$ & 14,83 & 2,76 & 3,38 & 14,31 & 6,81 & 14,15 & 9,35 & 15,68 & 20,17 & 29,90 & 11,15 \\
\hline & Saũde & 505,55 & 120.43 & 168.29 & 155,71 & 153,69 & 257.94 & 288,50 & 402,87 & 676,76 & 966,39 & 1379,59 \\
\hline \multirow[t]{3}{*}{ SĀO PAULO } & Trat.Dent.: & 82.91 & 2,25 & 18,87 & 14,60 & 15,05 & 62,01 & 64,71 & 82,24 & 107,40 & 148.74 & 210,31 \\
\hline & $\%$ & 16,40 & 1,87 & 11,21 & 9.38 & 9.79 & 24,04 & 22,43 & 20,41 & 15,87 & 15,39 & 15,24 \\
\hline & Saúde & 593.75 & 102,46 & 195,93 & 154,36 & 154,59 & 275,69 & 602,84 & 479,04 & 708,67 & 831,13 & 1532,38 \\
\hline \multirow[t]{3}{*}{ CURITIBA } & Trat.Dent.: & 100,21 & 4,27 & 11,91 & 27,41 & 14,60 & 32,13 & 50,11 & 78.64 & 207,61 & 184,47 & 379,72 \\
\hline & $\%$ & 19,89 & 4,17 & 6,08 & 17,76 & 9.44 & 11,65 & 8,31 & 16,42 & 29,30 & 22,19 & 24,78 \\
\hline & Saudeü & 427,81 & 77.29 & 104,70 & 144,70 & 140,21 & 221,99 & 255.25 & 332,09 & 544,87 & 853,37 & 1901,32 \\
\hline \multirow[t]{3}{*}{ P.ALEGRE } & Trat.Dent.: & 55.27 & 1,80 & 3,59 & 14,83 & 5,84 & 24,27 & 48,53 & 52,80 & 76.39 & 234,35 & 136,16 \\
\hline & $\%$ & 12,92 & 2,33 & 3,43 & 10,25 & 4,16 & 10,93 & 19,01 & 15,90 & 14,02 & 27,46 & 7,16 \\
\hline & Saúde & 494,32 & 116,39 & 107,85 & 174,36 & 142,68 & 240.42 & 256,60 & 392,31 & 486,00 & 720,80 & 1320,28 \\
\hline \multirow[t]{3}{*}{ BRASILIA } & Trat.Dent.: & 130.09 & 49,88 & 26.29 & 21.34 & 48,98 & 36.40 & 66.73 & 104,70 & 137,73 & 183.12 & 367.82 \\
\hline & $\%$ & 26,32 & 42,86 & 24,38 & 12,24 & 34,33 & 15,14 & 26,00 & 26.69 & 28,34 & 25,40 & 27,86 \\
\hline & Saúde & 626,43 & 97,07 & 302,12 & 231,43 & 253,67 & 286.25 & 594,08 & 569.59 & 639,24 & 961,00 & 1846,72 \\
\hline \multirow[t]{2}{*}{ GOIÂNIA } & Trat.Dent.: & 130,54 & 1.80 & 49,21 & 32,13 & 35,50 & 23,59 & 70,55 & 191,66 & 186,27 & 226.71 & 362,87 \\
\hline & $\%$ & 20,84 & 1,85 & 24.23 & 13.88 & 13,99 & 8.24 & 11.87 & 33.65 & 29.14 & 23.59 & 19.65 \\
\hline
\end{tabular}


TABELA 18

GASTOS PESSOAIS ESTIMADOS COM ATENÇÃO A SAÜDE GERAL

SEGUNDO A REGIĀO E A ZONA DE RESIDENCCIA-BRASIL, 1989

\begin{tabular}{|c|c|c|c|c|c|c|c|c|}
\hline \multirow[b]{2}{*}{ REGIÃO } & \multicolumn{2}{|c|}{ R.M. E CAPITAIS } & \multicolumn{2}{|c|}{ DEMAIS CIDADES } & \multicolumn{2}{|c|}{ RUAAL } & \multicolumn{2}{|c|}{ TOTAL } \\
\hline & \begin{tabular}{|c} 
GASTO \\
PEA CAP \\
\end{tabular} & $\begin{array}{c}\text { GASTO TOTAL } \\
\text { (US\$ mil) }\end{array}$ & $\begin{array}{c}\text { GASTO } \\
\text { PER CAP }\end{array}$ & $\begin{array}{c}\text { GASTO TOTAL } \\
\text { (US\$ mil) }\end{array}$ & $\begin{array}{c}\text { GASTO } \\
\text { PEA CAP }\end{array}$ & $\begin{array}{l}\text { ASTO TOTA } \\
\text { (US\$ mil) }\end{array}$ & $\begin{array}{c}\text { GASTO } \\
\text { PEA CAP }\end{array}$ & $\begin{array}{c}\text { GASTO TOTAL } \\
\text { (US } \$ \text { mil) }\end{array}$ \\
\hline NORTE & 79,32 & 184181 & 55.52 & 111706 & 24,59 & 87393 & 48,59 & 383280 \\
\hline NORDESTE & 61,73 & 625572 & 33,33 & 418858 & 17.28 & 312129 & 33,28 & 1356559 \\
\hline SUDESTE & 109,44 & 3645227 & 88.65 & 2066875 & 33,93 & 263874 & 92,79 & 5975976 \\
\hline SUL & 123,37 & 716039 & 116.40 & 1065060 & 53,48 & 361739 & 98,67 & 2142838 \\
\hline C.OESTE & 126.68 & 505453 & 88.68 & 300714 & 39,27 & 78304 & 94,34 & 884471 \\
\hline BRASIL & 102,17 & 5676472 & 78,58 & 3963213 & 28,92 & 1103439 & 74,53 & 10743124 \\
\hline
\end{tabular}

Fontes: Bibliografias $107,109,127,128$. 


\section{: 6.2. Gastos Pessoais com Atenção Odontológica}

Cada brasileiro despendeu, em média, do próprio bolso, cerca de 11,63 dólares no ano de 1989 com "tratamento dentário" e isto representou um movimento total de US\$1.677.124.000,00 no país, segundo a Tabela 19(44,47, 52, 54, 105, 107, 113, 114, 118, 119, 120,147,1149,217,223).

Se considerassemos os 86598 Cirurgiões-Dentistas em atividade naquele ano, teríamos um rendimento bruto médio a partir dessa fonte de 1614 dólares mensais por profissional $\mathrm{Na}$ prática há grandes diferenças entre profissionais e entre regiões, além de uma apropriação de recursos muito significativa por parte da indústria odontológica, que também retira sua sobrevivência deste montante.

$55 \%$ das despesas acontecem nas R.M. e capitais; $36 \%$ nas localidades do interior e apenas 98 na zona rural, mostrando que os gastos odontológicos são ainda mais recessivos que os gastos gerais com saúde e que a distribuiçāo global de rendimentos, ao concentrarem-se com maior intensidade nos principais centros urbanos e ao deixar as populações camponesas mais desassistidas.

Este fenômeno se repete em relação às regiões. Segundo a Tabela 20, por exemplo no Nordeste onde está 288 da população, concentram-se somente 158 dos rendimentos, 138 dos gastos totais em saúde e 128 dos gastos em odontologia; ao passo que por exemplo na região Centro-oeste estas proporções são respèctivamente de $6,5 \%$ $8 \%$ - 88 e 13\%. Em saúde as perdas das regiōes Norte e Nordeste terminam por ajudar as demais, num desequilíbrio que - se realmente não consegue beneficiar as populaçōes econômicamente melhor situadas devido em boa parte aos baixos niveis de eficiência com que trabalha o setor - tem efeitos desastrosos sobre os menos favorecidos, pois diminui o acesso a serviços que lhes são ainda mais essenciais pelas severas condições econômicas que enfrentam.

Em saúde bucal há importantes diferenças no comportamento das áreas pública e privada quanto aos recursos movimentados nas cinco regiōes em que se divide 0 país. o Norte e 0 Nordeste são prejudicados em todos os casos, mas a penalização é bem maior no caso dos servicos privados, os quais na prática comportam-se de maneiras a evitar as comunidades de menor poder aquisitivo, privilegiando em consequência os centros financeiramente mais abonados do Sudeste, Sul e Centro-Oeste. 


\section{TABELA 19}

GASTOS PESSOAIS ESTIMADOS COM ATENÇĀO ODONTOLÓGICA

SEGUNDO A REGIÃO E A ZONA DE RESIDENCIA - BRASIL, 1989

\begin{tabular}{|c|c|c|c|c|c|c|c|c|c|c|c|c|}
\hline \multirow[b]{2}{*}{ REGIĀO } & \multicolumn{3}{|c|}{ R.M. E CAPITAIS } & \multicolumn{3}{|c|}{ DEMAIS CIDADES } & \multicolumn{3}{|c|}{ RURAL } & \multicolumn{3}{|c|}{ TOTAL } \\
\hline & $\begin{array}{c}\text { GASTO } \\
\text { PER CAP }\end{array}$ & $\begin{array}{c}\text { POPUL. } \\
\text { (mil) }\end{array}$ & $\begin{array}{c}\text { GASTO TOTAL } \\
\text { (US\$ mil) }\end{array}$ & $\begin{array}{c}\text { GASTO } \\
\text { PER CAP }\end{array}$ & $\begin{array}{c}\text { POPUL. } \\
\text { (mil) }\end{array}$ & $\begin{array}{c}\text { GASTO TOTAL } \\
\text { (US } \$ \text { mil) }\end{array}$ & $\begin{array}{c}\text { GASTO } \\
\text { PEA CAP }\end{array}$ & $\begin{array}{l}\text { POPUL. } \\
\text { (mil) }\end{array}$ & $\begin{array}{c}\text { GASTO TOTAL } \\
\text { (US } \$ \text { mil) }\end{array}$ & $\begin{array}{l}\text { GASTO } \\
\text { PEA CAP }\end{array}$ & $\begin{array}{l}\text { POPUL. } \\
\text { (mil) }\end{array}$ & $\begin{array}{c}\text { GASTO TOTAL } \\
\text { (US\$ mil) }\end{array}$ \\
\hline NORTE & 8,29 & 2322 & 19249 & 5,80 & 2012 & 11670 & 2,57 & 3554 & 9134 & 5,08 & 7888 & 40053 \\
\hline NORDEST & 6.73 & 10134 & 68202 & 3,63 & 12567 & 45945 & 1,88 & 18063 & 33958 & 3,63 & 40764 & 148105 \\
\hline SUDESTE & 18,05 & 33308 & 601209 & 14,62 & 23315 & 340865 & 5.60 & 7777 & 43551 & 15.30 & 64400 & 985625 \\
\hline SUL & 19.59 & 5804 & 113700 & 14.50 & 9150 & 132675 & 6.66 & 6764 & 45048 & 13,42 & 21718 & 291423 \\
\hline C.OESTE & 30.35 & 3990 & 121096 & 21.25 & 3391 & 72059 & 9.41 & 1994 & 18763 & 22,60 & 9375 & 211918 \\
\hline BRASIL & 16.62 & 55558 & 923456 & 11.96 & 50435 & 603214 & 3.94 & 38152 & 150454 & 11.63 & 144145 & 1677124 \\
\hline
\end{tabular}

Fontes: Bibliogralias 5,16,107,109,127,128. 
TABELA 20

PARTICIPACCÃO PEACENTUAL DAS REGIOES SOBRE A

RENDA, POPULAÇÃO, GASTOS PESSOAIS COM SAÜDE

GERAL E SAÚDE BUCAL - BRASIL, 1989

\begin{tabular}{|c|c|c|c|c|c|c|}
\hline \multirow[t]{2}{*}{ REGIÃO } & \multirow{2}{*}{$\begin{array}{c}\text { RENDIMENTOS } \\
\text { TOTAIS }\end{array}$} & \multirow[t]{2}{*}{ POPULAÇĀO } & \multirow{2}{*}{$\begin{array}{l}\text { GASTOS COM } \\
\text { SAUUDE GERAL }\end{array}$} & \multicolumn{3}{|c|}{ GASTOS COM SAUDE BUCAL } \\
\hline & & & & TOTAL & PUBL. & PAIV. \\
\hline NORTE & 4,82 & 5.47 & 3.57 & 2.64 & 3,21 & 2,39 \\
\hline NORDESTE & 15,39 & 28,28 & 12,63 & 11.63 & 17,98 & 8,83 \\
\hline SUDESTE & 57,01 & 44,68 & 55,63 & 55,41 & 47,79 & 58,77 \\
\hline SUL & 15,09 & 15,07 & 19,94 & 19,44 & 24,12 & 17,38 \\
\hline C.OESTE & 7.69 & 6.50 & 8.23 & 10,88 & 6,90 & 12,63 \\
\hline
\end{tabular}

Fonle: Dados das Tabelas 16 e 17 
: 6.3. Gastos Institucionais e Totais em Saúde Bucal

- sub-setor institucional pode ser dividido, para efeitos de apropriação de gastos, em seis grandes blocos: I) a previdência social, englobando os serviços próprios do INAMPS, os profissionais e empresas credenciadas, os sindicatos e o que é pago aos órgãos públicos contratados; II) as Secretarias Estaduais de Saúde e de Educação, que reúnem os cuidados prestados em centros e postos de saúde e nas escolas; III) as Secretarias Municipais de saúde e de Educação; IV) Outras Instituições, reunindo um leque que vai desde os Serviços Sociais da Indústria e do Comércio (SESI, SESC) até unidades próprias ou contratadas em polícias, fundações e outras instituiçōes direta ou indiretamente custeadas com recursos públicos; V) Ministério da Saúde, que compreende os gastos da Divisão Nacional de Saúde Bucal e da Seç̧ão de saúde oral da Fundação SESP; VI) a manutenção dos sistemas de fluoretação da água em 1222 localidades em todo o país.

A exemplo dos dados referidos nos dois tópicos anteriores, os critérios aqui empregados estão descritos no Anexo III.

Do conjunto de estimativas feitas com base no número de serviços, recursos humanos e contratos apresentados no Capitulo 5.2, tornou-se posível construir a Tabela 21 na qual estão condensados os gastos para os seis grandes blocos, segundo a regiāo e incluindo um detalhamento para as quatro sub-divisōes relativas aos gastos previdenciários.

Até onde é possivel conhecer a contabilidade setorial, na Tabela 21 não há dupla contagem de recursos aplicados, uma vez que nas colunas correspondentes às Secretarias Estaduais e Municipais constam apenas os quantitativos provenientes dos cofres estaduais e municipais; o que é transferido pela previdência social para essas Secretarias está computado na coluna "INAMPS/órgãos públicos".

Assim, temos que através das instituiçōes oficiais e paraoficiais foram utilizados para prestação de cuidados à saúde bucal da população em 1989, em torno de US\$ 711,3 milhōes. Deste montante, somente US\$: 9,6 milhões destinaram-se à prevenção coletiva da cárie dental através da fluoretação da água de abastecimento público, que era o método de escolha a nível nacional alcançando cerca de 64 milhōes de pessoas.

A soma dos recursos institucionais com os dispêndios pessoais resulta num montante de US\$ 2,4 bilhöes de dólares para atender despesas relacionadas à saúde bucal no Brasil durante 0 ano de 1989 .

Mesmo reunindo os serviços prestados em suas quatro modalidades principais, o INAMPS participa com pouco menos de 88 (junto com o Ministério da Saúde chega a $8,8 \%$ ) do custeio das atividades odontológicas a nivel nacional, o que é praticamente 0 mesmo que cabe às Secretarias Municipais e Estaduais, mas bastante inferior ao que é pago do próprio bolso pelas pessoas (70\% do total), como mostra o Gráfico VI. 
Existem várias análises possiveis a partir do conteúdo da Tabela 21, procurando-se nos itens abaixo limitar a discussão aos enfoques mais relevantes sobre cada bloco institucional e suas interrelações.

a) - apesar da gradual e significativa redução do papel das unidades próprias no volume de serviços produzidos ou custeados pelo INAMPS (vide Tabela 14), elas ainda detém a fatia predominante com 408 dos dispêndios previdenciários em odontologia. Isto se deve a duas razões principais, quais sejam a baixa remuneração dos serviços contratados e os comparativamente altos salários pagos ao pessoal próprio que envolvem adicionalmente gastos com manutenção de clínicas e com encargos sociais;

b) - os profissionais credenciados pela previdência diminuiram sua participação tanto no aspecto produtivo quanto nos gastos da instituição, limitando-se a captar 178 dos recursos num percentual que coincide que a proporção de serviços prestados em 89. Ao contrário dos demais prestadores, os credenciados concentram suas atividades e seus ganhos principalmente nas regiöes sul e sudeste;

c) - os sindicatos urbanos e rurais, que também perderam importância para o INAMPS a partir de 1986, chegaram ao final da década com uma execução em torno de 298 dos serviços e uma captação de 158 dos recursos. Uma explicação possível para essa discrepância de números está na não fixação de tetos pelo INAMPS para a produção e custeio dos sindicatos, o que pode tê-los induzido a apresentar faturas com super-produção artificial de serviços na esperança de receber mais. Das trếs regiöes com maiores contingentes de população rural, os sindicatos aparecem com alguma significância somente no nordeste, num sintoma a mais da descaracterização dos serviços voltados para os camponeses ocorrida desde a extinção do FUNRURAL;

d) - não obstante o célere aumento, na década, de recursos concedidos ao financiamento dos órgãos públicos pela previdência, os 45,6 milhões de dólares destinados às secretarias de Saúde e Educação dos estados e municípios significaram tão somente a undécima parte do que foi por estas aplicado em atenção odontológica no ano. O fato de que, no universo previdenciário, os órgãos públicos tenham executado cerca de 448 dos serviços e faturado 258 do orçamento específico reflete principalmente a baixa remuneração praticada, "embora não se possa descartar a possibilidade de imprecisōes ou mesmo de superestimativas nos dados de produção, na esperança de que pudessem ser pagos os excedentes aos tetos praticados pelo INAMPS (as entidades públicas tiveram desde 86 seus Iimites expandidos mas as restrições orçamentárias terminaram, ainda que de forma mais favorável, por impor tetos nos pagamentos);

e) - no desempenho financeiro do âmbito estadual cabe destacar a predominância das regiões sudeste e Nordeste em consequência do elevado número de profissionais contratados no primeiro caso pelas Secretarias de São Paulo e também do Rio e de Minas e, no segundo caso, do Ceará, Pernambuco e Paraiba principalmente. Todas as 
unidades federadas investem na prestaçāo de cuidadós odontológicos à população, estando as variações observadas na Tabela 21 mais ligadas à capacidade econômica de cada uma do que a influências artificiais como por exemplo no caso dos serviços previdenciários;

f) - as municipalidades deram um grande salto na sua representatividade dentro do setor público desde que se manifestou a tendência a seu favor em 86 , confirmada quando da aprovação do texto constituinte em 88 . A presença de prefeituras econômicamente fortes nos três maiores estados do sudeste e também no sul condicionam a presença de gastos bem màis elevados nestas duas regiões em relação às demais, prevendo-se que esta situação não deverá ter mudanças significativas durante a década de noventa. Se em relação ao total de recursos os municípios participaram com $7,8 \%$ do financiamento em 89, no caso particular da regiāo Nordeste esta proporção limitou-se a 4,48 , fixando-se em 5,28 no Centro-Oeste e em 3,8 s no Norte.

g) - no âmbito das "outras instituições", que abrange um extenso leque de entidades, destacam-se por estarem presentes na maioria dos estados, o Serviço Social da Indústria com 2036 Cirurgiões-Dentistas contratados em seus vinte e cinco Departamentos Regionais e o Serviço Social do Comércio. Na prática, têm peso quase similar ao dos outros três grandes do setor público, com a particularidade de que os seus maiores gastos acontecem na regiāo sul;

h) - reunidos, os dispêndios da Divisão Nacional de Saúde Bucal (US\$ 13,1 milhōes) e da Fundação SESP (US\$ 6,5 milhões) representaram somente 0,88 dos gastos totais e 2,68 dos institucionais em 89. Embora limitados, constituem um bom exemplo de redistribuição de investimentos, ao privilegiarem nitidamente as regiōes Nordeste e Norte. Acrescente-se ainda que parte desses recursos foram utilizados no custeio de um extenso prodrama preventivo nos estados;

i) - o Ínfimo custo relativo da linha de prevenção da cárie dental através da fluoretação da água de consumo público (cerca de US\$ 0,15 por habitante) fica ainda mais claro quando se vê que a manutenção desta medida significou no ano 0,48 do total e 1,38 do orçamento institucional, além de não onerar na maioria dos estados o setor saúde já que sua implementação cabe essencialmente às companhias de abastecimento d'água;

j) - a relação entre gastos públicos e privados, na área odontológica, é de $3: 7$, num claro indicativo do carater privado deste sub-sistema num país onde a maior parte da sua população não dispõe de recursos para frequentar consultórios particulares. Isto ocorre devido à forte influência das clínicas privadas nas regiōes Sudeste e centro-Oeste, compensando com sobras a quase igualdade verificada no Nordeste onde $45 \%$ dos recursos têm origem institucional. Como se pode depreender através da Tabela 21\% um dos principais problemas relacionados à perversa distribuição regional dos recursos aplicados pela nação em saúde bucal situa-se na grande 
concentração de capitais privados nos núcleos urbanos de mais alta renda do Sudeste e do Centro-Oeste.

\section{: 6.4. Análise Conjunta}

$\mathrm{Na}$ década de oitenta houve um significativo aumento no volume total de gastos com saúde geral, que passou aproximadamente de 13 em 1981 para 22 bilhões de dólares em 1989. Apesar do crescimento da base financeira, os serviços sofreram uma inegável deterioração na ponta da rede, crescendo em paralelo as desconfianças e as descrenças da população para com os profissionais de saúde, mormente os da área médica. Este parece ser o resultado de um processo de crescimento desordenado, no qual instituiçōes tradicionais foram desestabilizadas sem a implantação de um modelo que pudesse dar melhores resultados com certa rapidez.

No setor público a grande expansão deu-se ao nível local, o que se espera será muito benéfico a médio prazo. Mas o movimento de municipalizaçāo nāo tem conseguido transformar-se em um processo ordenado e sólido, continuando muito dependente dos repasses federais. A luta pelos recursos, particularmente os provenientes das transferências do INAMPS, tem consumido a maior parte das energias dos municípios. o modelo de prestação de cuidados à população não mudou na grande maioria dos municípios. 0 modelo tradicional implantado pelo INAMPS continua vigente. Em muitos estados e municipios, as secretarias de Saúdé continuam débeis ao ponto de muitas vezes perderem para outras finalidades as verbas que lhe são repassadas. Assim, parte significativa dos recursos continuam não conseguindo chegar ao seu destino final, ou seja, à população. As lutas internas entre estados e municípios ou entre ambos e o governo federal, nem sempre se limitam às particularidades do setor saúde e com frequência são submetidas aos interesses maiores de ordem política ou econômica; em consequência nos últimos anos o processo de transferência ordenada de atribuiçōes, programas, etc.' para o poder municipal, que em grande parte deveria caber aos governos federal e dos estados, tem sido prejudicado ao ponto de transformar-se em um voluntarismo que desfavorece nitidamente as localidades menores ou com menor tradição no setor.

Os gastos privados também cresceram bastante, com destaque desta feita para a modalidade de seguros-saúde na forma principalmente de contratos coletivos via empresas, ou seja, como salários indiretos subsidiados por descontos do imposto de renda.

Ainda pouco influenciada pelos seguros (embora as formas de pré-pagamento estejam em forte processo de expansão mormente nas capitais de maior porte, tem pequeno peso no movimento financeiro total da área odontológica), o grande aumento de gastos privados com assistência odontológica deu-se em essência através da prática liberal tradicional, a qual continua predominante.

$\mathrm{Na}$ comparação com os dados de $81(108)$, os dispêndios nacionais com odontologia passaram de 557 milhões para 2,4 bilhões de dólares entre 81 e 89 , mas é provável que os recursos aplicados em 81 pelos 
municipios estivessem subestimados devido às severas dificuldades em obter informaçōes adequadas à época. De qualquer maneira, não há como negar um extraordinário alargamento na participação municipal no plano da assistência odontológica à população. Ao que tudo indica, no processo gradativo de municipalização ocorrido no último decênio, as administraçōes locais - em geral sem tradição no fornecimento de cuidados médicos especializados e de hospitalização â população - enfatizaram muito os serviços odontológicos, até mesmo pela relativa simplicidade e facilidade de implementação de um tipo de serviço que certamente era desejado pela comunidade. 


\section{GRÁFICO IV}

GASTOS PUBLICOS E PRIVADOS EM SAUDE BUCAL - BRASIL 1989

(Em US $\$$ milhoes)

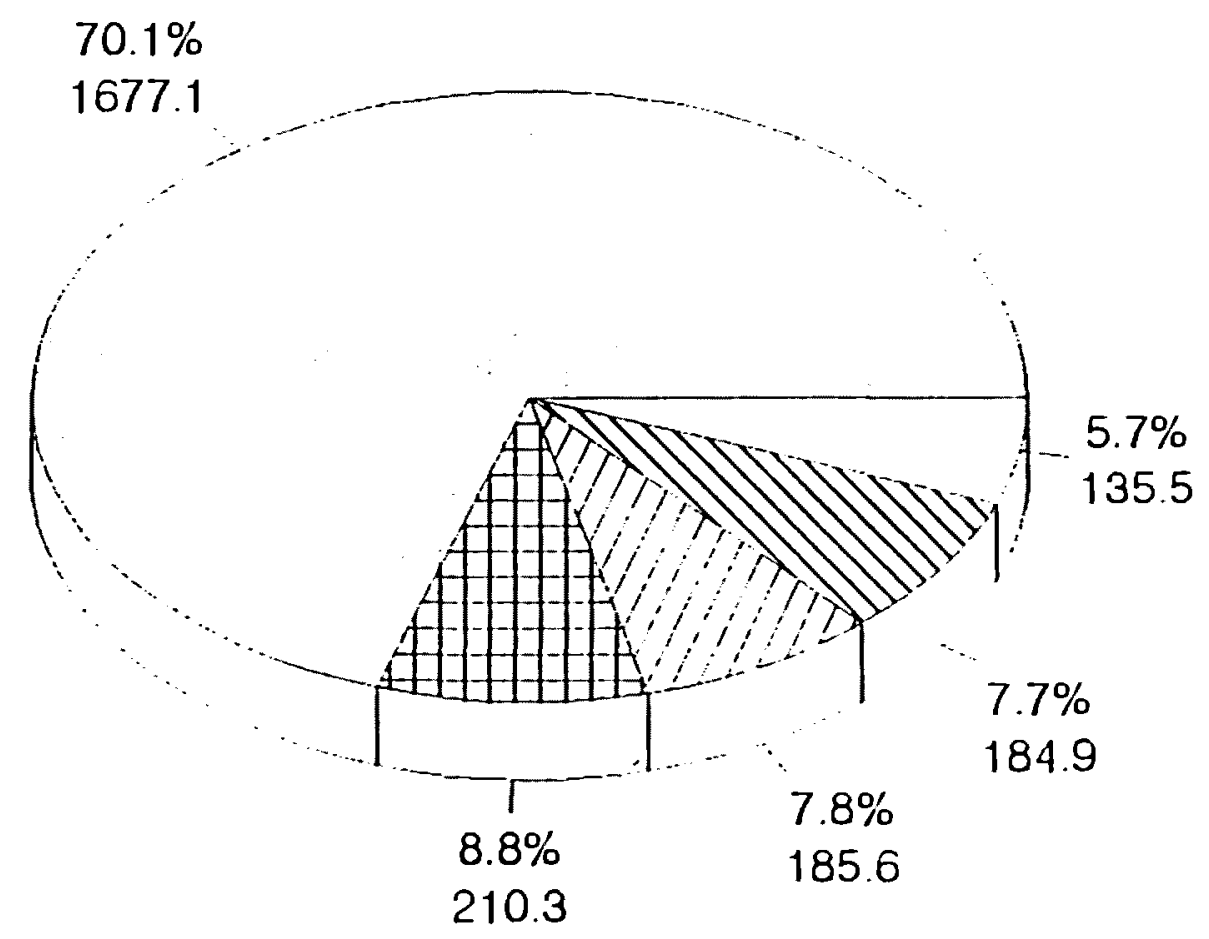

$\square$ OUTRAS INSTIT. $\quad$ DPREF. MUNIC. $⿴$ SEC.SAUDE E EDUC. $\boxplus$ INAMPS E FSESP $\square$ GASTOS PESSOAIS 
TABELA 21

GASTOS PÚBLICOS E PRIVADOS EM SAÚDE BUCAL

SEGUNDO A FONTE DE DESPESAS E A REGIAO - BRASIL, 1989 (em US\$ milhరes)

\begin{tabular}{|c|c|c|c|c|c|c|c|c|c|c|c|c|}
\hline \multirow[t]{2}{*}{ REGIĀO } & \multicolumn{4}{|c|}{ INAMPS } & \multirow{2}{*}{$\begin{array}{l}\text { SEC.SAƯDEI } \\
\text { EDUCAÇĀO }\end{array}$} & \multirow{2}{*}{$\begin{array}{l}\text { MUNI- } \\
\text { CIPIOS }\end{array}$} & \multirow{2}{*}{$\begin{array}{l}\text { OUTRAS } \\
\text { INSTIT. }\end{array}$} & \multirow{2}{*}{$\begin{array}{l}\text { MINIST. } \\
\text { SAÜDE }\end{array}$} & \multirow{2}{*}{$\begin{array}{c}\text { FLUORET. } \\
\text { AGUA }\end{array}$} & \multirow{2}{*}{$\begin{array}{c}\text { TOTAL } \\
\text { PÜBLICO }\end{array}$} & \multirow{2}{*}{\begin{tabular}{|c|} 
GASTOS \\
PESSOAIS
\end{tabular}} & \multirow[t]{2}{*}{ TOTAL } \\
\hline & PROPRIO & CREDENC. & SINDIC. & ठRG.PÜBL. & & & & & & & & \\
\hline NORTE & 2491 & 581 & 867 & 237 & 9771 & 2406 & 3557 & 3563 & 134 & 23607 & 40053 & 63660 \\
\hline NORDEST & 20149 & 7066 & 1840 & 6062 & 47039 & 12430 & 17923 & 10045 & 1230 & 123784 & 148105 & 271889 \\
\hline SUDESTE & 33295 & 9098 & 11001 & 25839 & 86271 & 101792 & 58912 & 2946 & 6047 & 335201 & 985625 & 1320826 \\
\hline SUL & 10739 & 12000 & 10823 & 11277 & 23015 & 56120 & 40169 & 1592 & 1629 & 167364 & 291423 & 458787 \\
\hline C.OESTE & 3792 & 1202 & 1967 & 2201 & 21118 & 14105 & 14938 & 1434 & 560 & 61317 & 211918 & 273235 \\
\hline BRASIL & 70466 & 29947 & 26498 & 45616 & 187214 & 186853 & 135499 & 19580 & 9600 & 721273 & 1677124 & 2398397 \\
\hline
\end{tabular}




\section{A QUESTÃO EPIDEMIOLÓGICA}

: 7.1. O Levantamento Epidemiológico Nacional

$:$ : $\quad 7.1 .1$. Sintese

- "Levantamento Epidemiológico em Saúde Bucal: Brasil, zona urbana, 1986" realizado pelo Ministério da Saúde com recursos do FINSOCIAL e apoio técnico do IPEA, serve de base para as estimativas feitas neste trabalho(34).

Trata-se do único estudo de nível nacional já levado a efeito no Brasil, com uma amostragem confiável e uma metodologia uniforme. Foi feito com o objetivo geral de conhecer os níveis de prevalência dos principais problemas odontológicos na zona urbana e fornecer subsídios para a implantação de um programa nacional de saúde bucal (BRASIL, 1988).

Quatro problemas foram estudados - cárie dental, doenças periodontais, uso e necessidades de prótese total (dentaduras) e procura por atendimento odontológico -, abrangendo dez grupos etários: $6,7,8,9,10,11,12,15$ a 19,35 a 44 e 50 a 59 anos.

Considerando a possível imprecisão de resultados na fase da dentição mista e a não aplicabilidade de índices de prótese em crianças, os problemas periodontais e protéticos só foram estudados nos grupos de adolescentes e adultos, ou seja, a partir dos 15 anos.

Os dados estão estratificados por renda familiar 10 a 2,3 e 4, 5 e mais salários-mínimos) para as cinco grandes regiões em que se divide o país: sul, sudeste, centro-oeste, norte e nordeste. 25.407 pessoas foram examinadás em dezesseis capitais brasileiras, sendo estas cidades consideradas como representativas da situação epidemiológica da população urbana, uma vez que os estudos disponíveis principalmente em crianças não mostravam diferenças consistentes nos índices de doença de pessoas residentes em capitais e em cidades do interior.

Compuseram o estudo: (a) Indice de Ataque de Cárie Dental CPO-D (Dentes Cariados, Perdidos e obturados), (b) Indice Comunitário de Necessidades de Tratamento Periodontal-ICNTP (ou "CPITN = Community Periodontal Index for Treatment Needs), (c) Indice de Necessidade e Uso de Prótese Total. Além disto, cada pessoa examinada respondia se procurara ou não atendimento odontológico no último ano.

A seleção da amostra incluiu de um lado estabelecimentos de ensino de 10. e 20. grau e, de outro lado, domicílios residenciais selecionados a partir dos setores censitários utilizados pelo IBGE. Os exames efetivaram-se em escolas e em residências.

Um extraordinário volume de informaçōes - mais de quinhentos mil dados no total - foi colocado à disposição dos profissionais brasileiros nesse estudo. Alguns dos enfoques adotados assumiram 
conotaçōes de ineditismo em termos de saúde pública: a inclusão de adolescentes e adultos, a adoção do ICNTP, o estudo dos problemas ligados à prótese, a segmentação regional e a unidade nacional, além da estrita comparabilidade com dados internacionais trabalhados pela organização Múndial da Saúde e pela Federação Dentária internacional.

Tão logo o estudo foi completado, seus dados originais ficaram à disposição das instituiçōes e dos pesquisadores do país. Na prática, tem sido de grande utilidade principalmente para as instituições prestadoras de serviços, mas seu aproveitamento a nível de pesquisa científica pode ser considerado como extremamente limitado.

\section{:: 7.1.2. Pontos a Equacionar}

A publicação apenas dos números referentes à amostra estudada, sem um tratamento estatistico especifico, só se justifica pela necessidade de apresentação dos resultados iniciais com rapidez e pela não existência de um grupo técnico ou de pesquisadores com tempo e recursos que lhes permitisse aprofundar a análise dos dados originais.

Entre os aspectos não equacionados até o momento, encontram-se por exemplo a análise estatística das diferenças regionais e de diferenças por estratos de renda, estimativas para outros grupos etários e a aplicação dos dados amostrais ao conjunto da população.

Neste trabalho procura-se desenvolver tais pontos, completando dentro das limitações impostas pelos dados disponiveis o esforço iniciado com a realização do estudo nacional.

A análise estatística que é feita a seguir envolve os índices relacionados à cárie dental, às doenças periodontais, aos problemas protéticos e à busca de atendimento, com estimativas para a população urbana brasileira de 5 a 79 anos.

Observando os resultados relativos à amostra e particularmente as Tabelas 4.7 e 8.7 da publicação original, optou-se por não aprofundar o estudo de possíveis diferenças de indices por regióes.

Da análise comparativa que se pode proceder em relação aos dados epidemiológicos e de procura de atendimento segundo os dados primários, é possível concluir que não há um padrão global ou uma tendência uniforme ou preponderante em termos regionais no país. Os dados não permitem sustentar qualquer afirmativa de superioridade ou inferioridade de uma região perante as demais no conjunto, tendo em vista que as melhores e piores posições em um hipotético "ranking" nacional alternam-se na dependência do indicador ou do grupo etário selecionado.

Em relação à cárie dental, p.ex., o Nordeste apresenta a melhor condição relativa na população jóvem e adulta, mas no grupo de 6 a 9 anos predomina o Sul e de 10 a 14 anos o sudeste. As mais favoráveis condições periodontais alternam-se segundo a idade entre 
- Sul e o Nordeste e quanto à prótese com raras exceções não há diferenças de significado estatístico entre quatro das cinco regiōes (a exceção é o Nordeste, com a pior situação). Finalmente, se considerarmos como um signo positivo o fato de que mais pessoas procurem atendimento odontológico - embora não se possa relacionar os indices de procura de atenção com os niveis de saúde bucal (PINTO, 1989) - os percentuais mais altos pertencem ao Norte, seguido pelo Centro-Oeste, depois pelo Nordeste e Sudeste juntos, ficando o sul com os menores índices.

: 7.2. Estimativas por Idade e Renda: Abrangência $\epsilon$ Metodologia Especifica

: $\quad$ 7.2.1. Abrangência fatores:

- presente estudo concentrou-se na análise dos seguinte:

- Indice CPO-D (Dentes Cariados-Perdidos-Obturados);

- componentes C+Ei (CariadostExtração Indicada, or necessidades de tratamento) e O+E (Obturados+Extraidos, or tratamentos realizados)do índice CPO-D;

- pessoas hígidas, com necessidades de tratamento periodonta. e edêntulas (sem dentes) segundo o indice CPITN;

- pessoas que não necessitam nem usam e pessoas que necessita ou usam prótese total;

ano.

- pessoas que receberam atenção odontológica no período de ur

Inicialmente foram feitas estimativas idade por idade, dos aos 79 anos com base sempre nos dados da amostra examinada $r$ Levantamento Epidemiológico em Saúde Bucal (34). Em seguida obteve se médias por grupos quinquenais de idade, ponderadas pel população urbana de cada idade estimada para $\circ$ ano de 1989. Ist significa aplicar os índices obtidos no estudo nacional ao ano mai. próximo para o qual seria possivel conseguir dados referentes: oferta de serviços e de recursos humanos e informaçōes sobre programas de prestação de serviços à população.

Admite-se, implícitamente, que os indices não sofreram modificações representativas entre 1986 e 1989, considerando principalmente que a expansão da linha de fluoretação de água em diversos estados é recente e ainda não produziu impactos significantes nos níveis de saúde oral da população com 5 anos e mais. 
:: 7.2.2. Modelo de Análise Estatística

- modelo de análise estatística foi desenvolvido por SOUZA(222), com base econométrica(94,206) e está descrito a seguir em relação ao índice CPO-D. O mesmo modelo foi utilizado para os demais indices e proporçōes.

a) - Variável dependente

Os dentes atacados pela cárie -CPO-D, foram medidos como sendo um percentual relativo ao total de dentes existentes na boca em cada idade. Pode ser interpretado neste contexto como uma probabilidade.

b) - Variáveis independentes

Classes de renda e idade

D1 = 1 se Classe 1 de renda, e 0 de outro modo.

$\mathrm{D} 2$ = 1 se Classe 2 de renda, e 0 de outro modo.

A Classe 1 corresponde a uma renda familiar de até 2 salários; a Classe 2 , de 2 até 5 salários.

Sendo $\mathrm{D} 1=0$, e $\mathrm{D} 2=0$, temos a Classe 3 (mais de 5 salários).

c) Modelo e Procedimentos

Ajustou-se um modelo de regressão linear do tipo "CPOD $=x$ + $\mathrm{YD} 1$ + zD2 + Desvio + Erro", com objetivo de obter estimativas do CPOD por classes de renda e idade e também acessar 0 impacto dessas variáveis na configuração linear (efeitos de renda e idade).

A fim de estabilizar a variância de distribuição residual e de torna-la aproximadamente normal utilizou-se a transformação arco-seno (dá como resultado o ângulo, em radianos, cujo seno é " $x$ "). Esta transformação mostrou-se mais adequada aos propósitos do estudo do que as obtidas nas tentativas com os modelos logístico e probito, alternativos ao modelo adotado. Os resultados alcançados apresentam alta significância e boa representatividade em termos de adequabilidade do modelo de previsão. O emprego da transformação arcsen (bem como a do probito) restringe os valores preditos e os intervalos de confiança aos limites entre 0 e 1 . Considerando-se $1=36$, evita-se assim que as estimativas sejam superiores em qualquer caso ao número total de dentes existentes na boca.

d) Resultados

Relativamente ao CPOD observa-se alta significância dos efeitos renda e idade no modelo ( $p<.01)$.

Com base no modelo ajustado foram feitas previsões pontuais e intervalares para as médias das várias populações envolvidas. Isto 
foi possível para idades e classes de renda presentes ou não no modelo amostral(222).

\section{:: 7.2.3. Dentição por Idade}

Para estabelecer o número médio de dentes presentes na boca em cada idade fixa, adotou-se três critérios:

(a) utilização dos dados reais coletados no Levantamento Epidemiológico em Saúde Bucal para as idades de $6,7,8,9,10,11,12,15,16,17,18$ e 19 anos;

(b) estimativas para as idades de 5,13 e 14 anos com base nos estudos de McDonald \& Avery(142), Graber(93) e Sato(211), e em projeções dos dados do Levantamento nacional(34);

(c) aceitação do total de 32 dentes presentes para as pessoas de 20 anos em diante. Embora existam pequenas variaçōes devido a alguns dentes com erupção tardia ou inclusos, considerou-se que a metodologia e os resultados do estudo não seriam afetados.

Pode-se considerar que os dados apresentados no Quadro 5 representam um padrão brasileiro médio de erupção da dentição permanente:

\section{QUADRO 5}

DENTES ERUPCIONADOS POR IDADE BRASIL, ZONA URBANA

$$
\begin{aligned}
& \text { * } 5 \text { anos }-2,50 \\
& \text { * } 6 \text { anos - 5,88 } \\
& \text { * } 7 \text { anos - 9,40 } \\
& \text { * } 8 \text { anos }-11,65 \\
& \text { * } 9 \text { anos - 14,82 } \\
& \text { * } 10 \text { anos - 18,95 } \\
& \text { * } 11 \text { anos - 23,16 } \\
& \text { * } 12 \text { anos - 25,71 } \\
& \text { * } 13 \text { anos }-27,10 \\
& \text { * } 14 \text { anos - 27,60 } \\
& \text { * } 15 \text { anos - 27,81 } \\
& \star 16 \text { anos }-28,03 \\
& \text { * } 17 \text { anos - 28,72 } \\
& \text { * } 18 \text { anos - 29,85 } \\
& \text { * } 19 \text { anos - } 30,33 \\
& \star 20 \mathrm{e}+-32,00
\end{aligned}
$$


: : 7.2.4. Médias por Idade e Renda

- modelo adotado para efetuar as estimativas fornece resultados para cada idade, estratificados segundo as três faixas de renda estabelecidas no Levantamento original.

Para estabelecer a média de cada grupo etário quinquenal ( 5 a 9, 10 a 14, etc.), optou-se por utilizar a população urbana de 1989 - o ano de referência do estudo - como fator de ponderação. Assim, para obter a média ponderada p.ex. do grupo de 5 a 9 anos, a fórmula é a seguinte:

$$
\begin{aligned}
& \left(A_{1} \star X_{1}+A_{2} \star X_{2}+A_{3} \star X_{3}+A_{4} \star X_{4}+A_{5} \star X_{5}\right) \\
& X_{1}+X_{2}+X_{3}+X_{4}+X_{5}, \text { onde } \\
& A_{1}=\text { CPOD aos } 5 \text { anos, } A_{2}=\text { CPOD aos } 6 \text { anos, etc., } e \\
& X_{1}=\text { População urbana de } 5 \text { anos, } x_{2}=\text { população de } 6 \text {, etc. }
\end{aligned}
$$

A estratificaçāo da população por faixas de renda seguiu os percentuais reais constatados pela Fundação IBGE para o ano de 1989, população urbana, para os "domicilios particulares permanentes sob condição de ocupação segundo a situação e as classes de rendimento mensal domiciliar". Considerou-se que era possível utilizar as divisōes por estrato de renda do IBGE (Até 2 salários-mínimos, 2 a 5 e Mais de 5) para as divisōes consideradas no Levantamento Epidemiológico (Até 2, 3 e 4 salários, 5 e Mais), pois neste último foi coletado apenas o número de salários ganhos mensalmente e não o valor monetário percebido, restando como ponto de possivel imprecisão somente aquelas pessoas que ganham exatamente 2 ou 5 salários-minimos, as quais terminam por compensar-se em parte no somatório dos componentes de cada faixa.

Assim, temos:

Até 2 Salários $=228$ da população

3 e 4 Salários $=328$ da população

5 e + Salários $=468$ da população.

Houve um arredondamento das proporções obtidas pela F.IBGE, cujos valores exatos foram 22,288 - 31,848 e 45,898 .

Estes valores foram considerados como válidos para todas as idades. Assim, para chegar à população segundo a renda, multiplicou-se o número total de pessoas de cada idade por 0,22; 0,32 e 0,46 , obtendo-se os resultados que compöem a Tabela I do Anexo IV. 


\section{: 7.3. Indicadores Positivos de Saúde Bucal}

Antes de apresentar os dados referentes a cada indice em particular, reune-se na Tabela 22 um conjunto de cinco indicadores tidos como positivos em saúde oral. São os percentuais de dentes hígidos (em contraposição aos dentes atacados pela cárie ou CPO), de pessoas com atendimento odontológico no último ano, dos que estão livres de próteses totais - ou seja, que nem as necessitam nem as possuem -, dos que possuem dentes (não edêntulos) e finalmente dos que não apresentam doenças periodontais.

As melhores condições, como o mostra o Gráfico $V$, pertencem ãs crianças $e$ aos adolescentes. Em todos os casos há uma gradativa deterioração das condições favoráveis até atingir a $3 a$. idade quando os piores indicadores prevalecem.

No primeiro grupo etário, de 5 a 9 anos, apenas dois terços dos elementos dentários estão sadios. Um terço, composto principalmente pelos molares dos seis anos e pelos incisivos já sofreram o ataque da cárie dental. Há uma rápida perda da higidez com a idade, de tal modo que entre 40 e 44 anos cada brasileiro residente em zona urbana mantem intactos menos de $30 \%$ dos seus dentes.

Os percentuais de pessoas que receberam cuidados odontológicos (pelo menos uma consulta no ano) é relativamente alto, sofrendo uma queda gradativa que pode ser tida como normal pois acompanha a redução na incidência de cárie na fase adulta, embora reflita também o grande volume de extraçōes praticado no país.

Em relação às "dentaduras", correspondendo aos que não sofreram extrações totais em um ou em ambos os maxilares, é interessante observar que pelo menos até o grupo de 25 a 29 anos a grande maioria (praticamente nove em cada dez) consegue manter a dentição em condições que em princípio são funcionais. Não obstante, isto acontece com 268 dos que têm entre 55 e 59 anos e com um só de cada cem entre os 75 e os 79 anos.

A proporção dos que não perderam todos os seus dentes, nos dois maxilares, é necessariamente superior ao dos que estão livres de próteses, e diminui também com maior lentidão. É uma medida indireta de manutenção da capacidade mastigatória, mesmo que limitada em muitos casos, estendendo-se a 608 das pessoas entre 50 e 59 anos e a pouco mais de 158 dos que se encontram no último grupo etário aqui considerado.

Em todos os casos é muito reduzida a parcela isenta de problemas periodontais, pouco mais de um quarto da população (não edêntula) na adolescência, não chegando a sete de cada mil entre 75 e 79 anos. 
TABELA 22

INDICADORES POSITIVOS EM SAÚDE BUCAL

SEGUNDO O GRUPO ETÁRIO. BRASIL, ZONA

URBANA.

\begin{tabular}{c|c|c|c|c|c}
\hline $\begin{array}{c}\text { GRUPO } \\
\text { ETÁRIO }\end{array}$ & $\begin{array}{c}\text { \% DENTES } \\
\text { HIGIDOS }\end{array}$ & $\begin{array}{c}\text { \% COM AT. } \\
\text { ODONTOL. }\end{array}$ & $\begin{array}{c}\text { \% LIVRE DE } \\
\text { PROTESE TOTAL }\end{array}$ & $\begin{array}{c}\text { \% COM } \\
\text { DENTES }\end{array}$ & $\begin{array}{c}\% \text { SEM D. } \\
\text { PERIOD. }\end{array}$ \\
\cline { 1 - 6 } 5 A 9 & 75,69 & 65,74 & - & - & - \\
10 A 14 & 69,63 & 63,11 & - & - & - \\
15 A 19 & 62,71 & 60,49 & 98,41 & 99,77 & 27,96 \\
20 A 24 & 55,73 & 57,71 & 89,23 & 98,67 & 24,19 \\
25 A 29 & 48,95 & 54,99 & 89,00 & 96,59 & 21,01 \\
30 A 34 & 41,98 & 52,25 & 80,90 & 93,64 & 17,43 \\
35 A 39 & 34,41 & 49,50 & 71,03 & 85,43 & 14,16 \\
40 A 44 & 28,65 & 46,73 & 59,91 & 81,76 & 9,01 \\
45 A 49 & 22,54 & 43,97 & 48,20 & 69,51 & 9,42 \\
50 A 54 & 16,99 & 41,24 & 36,64 & 60,27 & 7,08 \\
55 A 59 & 12,09 & 38,54 & 25,87 & 50,68 & 5,21 \\
60 A 64 & 7,92 & 35,90 & 16,51 & 41,13 & 3,62 \\
65 A 69 & 4,58 & 33,20 & 8,75 & 31,52 & 2,26 \\
70 A 74 & 2,13 & 30,81 & 3,69 & 23,10 & 1,31 \\
75 A 79 & 0,63 & 28,35 & 1,17 & 15,44 & 0,68 \\
\hline
\end{tabular}




\section{GRÁFICO V}

EVOLUÇĀO DE INDICADORES SELECIONADOS DE SAUDE BUCAL E DE OFERTA DE SERVIÇOS-5 A 79 ANOS DE IDADE - BRASIL

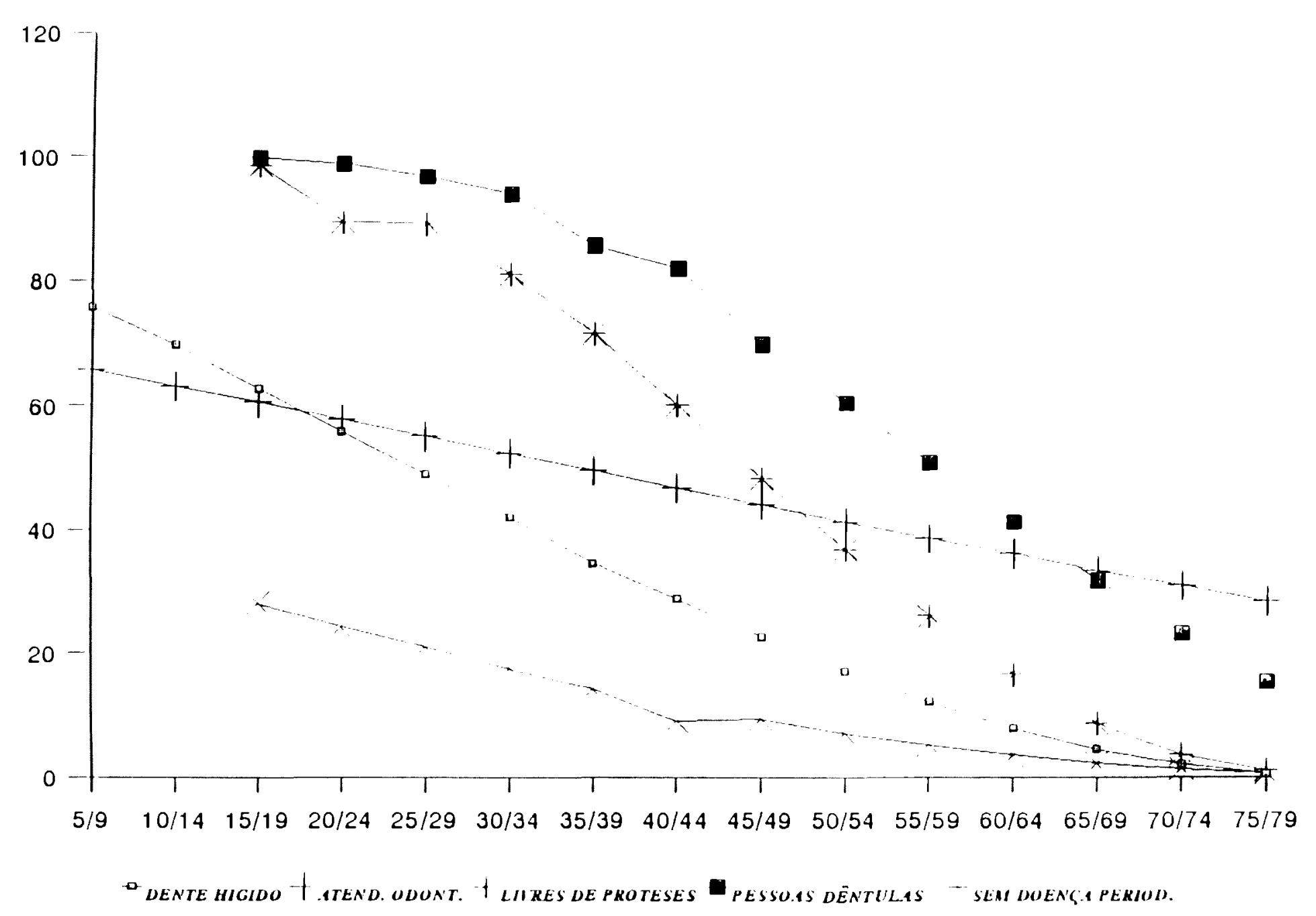

Fontes: Bibliografia 34, 226 


\section{: 7:4. Ataque de Cárie na População de 5 a 79 Anos}

As Tabelas 23 a 28 reunem os dados estimados para o índice CPO-D e componentes em relação à população de 5 a 79 anos de idade residente na zona urbana. Foram construidas sobre a base estatistica fornecida pelas Tabelas II a VIII (Anexo V), as quais também mostram os percentuais de dentes atacados pela cárie em relação ao total de dentes presentes na boca.

- modelo de análise estatística empregado tem altíssima significância para o CPO-D ( $R 2=0,97$, conforme Tabela III-Anexo V) e para os componentes $O+E$ ( $R 2=0,96$, Tabela $V$ ) e $C+E i$ (obtidos por diferença), indicando que o índice é quase que inteiramente explicado pelas variáveis idade e renda.

Há um ritmo crescente, e desde o começo acelerado, de ataque de cárie, mantendo níveis muito elevados em todas as idades e em todas as faixas de renda. Aos cinco anos de idade, quando em média apenas 2,5 primeiro-molares irromperam temos, no grupo de mais baixa renda por exemplo, que cerca de 198 dos dentes já estão afetados, portanto com um índice CPO-D de 0,467. A marca de dez dentes afetados por pessoa é alcançada aos 16 anos, os vinte dentes entre 35 e 36 anos enquanto que aos 65 anos a média de 30 elementos ou 958 do total já se constitui em um padrão nacional.

As diferenças por estrato de renda são sólidas e constantes no caso brasileiro, mas diminuem gradativamente com a idade, tendendo à igualdade no final da vida. Assim, aos 6 anos 0 índice CPO-D do estrato 5 ou mais salários-minimos de renda familiar tem um valor $(1,159)$ que representa 848 do índice do estrato com até 2 salários $(1,274)$, conforme a Tabela 23. Esta proporção é de 868 aos 12 anos, 888 aos 18 anos, quase 938 aos 35 , atingindo praticamente 978 aos 60 anos, 988 aos 70 e 99,38 aos 79 anos de idade.

As razões para as desigualdades epidemiológicas por renda ainda não estão suficientemente claras, podendo especular-se em torno de duas hipóteses e ainda não estudadas: consumo diferenciado de açúcares (formas menos cariogênicas) e efeitos positivos do maior acesso às clínicas odontológicas.

Quanto às causas da virtual similaridade do índice na $3 a$. idade, certamente situam-se na quantidade extremamente elevada de extrações que se pratica no país em todos os grupos sociais. Como se pode observar no Gráfico VI, que mostra o comportamento dos quatro fatores que constituem o CPO nas idades de $6,12,18,35$ e 60 anos, o grande determinante do forte e continuo crescimento do índice são as extrações que no início representam somente 1,48 do total e no final já tem uma participação equivalente a 84,58 .

Quando examinamos as relações entre tratamentos feitos $(O+E$, ou seja, dentes obturados e extraidos, equivale a problemas agudos resolvidos) e necessidades de tratamento ( $C+E i$, dentes Cariados $e$ com Extração indicada), vemos através das Tabelas 24 e 25 e do Gráfico , que unicamente o primeiro evolui paralelamente ao CPO, partindo da média de 0,15 aos 5 anos e chegando a 31,57 , ou seja, à 
totalidade dos dentes, aos 79 anos. Os fatores C+Ei têm uma evoluçāo inteiramente distinta: partindo da média de 0,32 aos 5 anos, atingem um ponto máximo de 5,33 aos 24 anos e logo voltam a decrescer para atingirem o mesmo ponto inicial entre 72 e 73 anos. Isto, na prática, significa que os elementos cariados (que são a grande maioria do sub-índice C+Ei) em geral não recebem tratamento oportuno, transformando-se em peças extraidas por motivos clínicos ou econômicos, estes últimos motivados pela falta de recursos para remunerar consultas em clínicas privadas.

Na população urbana de 5 a 79 anos de idade - 105,4 milhões de pessoas em 1989 (Tabela I) - estima-se que 1,48 bilhão de dentes foram ou estão atacados pela cárie dental (Tabela 26), dos quais 1,16 bilhão está restaurado ou já foi extraido (Tabela 27), e 318 mil permanecem cariados ou esperam por extração (Tabela 28).

Não obstante o indice de cárie aumente sempre com a idade, o ponto máximo do CPO é alcançado aos 28 anos com praticamente 34 milhões de dentes, diminuindo o número total a partir daí devido à gradativa e predominante redução da população idade por idade.

É interessante observar que, do total de 1,48 bilhão de dentes CPO, menos de $7 \%$ pertencem ao grupo considerado como epidemiologicamente prioritário, entre 5 e 14 anos de idade! Este grupo, no entanto, detém 18 o do total de C+Ei (com predominância forte para os dentes cariados) e 48 do total de tratamentos feitos (Tabelas 26 a 28). No Gráfico VI podemos ver que um programa de prevenção e de tratamento oportuno que enfatizasse a população de 5 a 24 anos, seria altamente benéfico, evitando o agravamento do quadro que se produz de modo particularmente severo entre 25 e 49 anos.

- Brasil possui larga tradição nos levantamentos epidemiológicos em crianças e de modo especial em escolares de 10. grau, mas o mesmo nāo ocorre em relação aos adolescentes e adultos, tanto que o estudo do Ministério da Saúde foi praticamente pioneiro neste campo. Recentemente, dois outros estudos abrangentes e com metodologia similar foram realizados, permitindo comparações com os dados nacionais.

Um deles, concretizado pelo SESI(138) junto a operários da construção civil do Distrito Federal, obteve resultados muito próximos aos aqui apresentados, como se vê no Gráfico VII.

o outro trabalho, de Rosa el alii(204) enfocou a população de 3a. idade da cidade de são Paulo. Para pessoas de 60 anos e mais encontrou um CPO-D de 29,77, quase idêntico ao índice de 30,21 para - grupo de 60 a 74 anos ou de 30,41 para os de 60 a 79 anos do presente estudo. Em ambos os casos detectou-se para as pessoas idosas uma situação altamente crítica do ponto de vista odontológico.

Tomando como referência $\bigcirc$ banco de dados da OMS (233.234) acrescido com informações de países latino-americanos(181), torna-se possível estabelecer uma comparação dos padrões de ataque pela 
cárie dental aos 12 anos de idade entre o Brasil e outras nações, como se pode ver através dos Gráficos VIII e IX.

Quinze países ainda possuem índices muito altos de cárie, com um CPO igual ou superior a 6,0 . Incluindo 0 Brasil, onze deles estão na América Latina; com exceção do Brunei Darussalam, as maiores prevalências de cárie também situam-se nesta área. Computando-se apenas os dados publicados pela OMS, o Brasil encontra-se na terceira posição negativa do "ranking" internacional da cárie em crianças, mas juntando-se os índices latino-americanos ainda não incorporados por Genebra, passamos aproximadamente para 0 oitavo posto.

Nos nove países mais populosos do mundo, com pelo menos cem milhões de habitantes cada um, observa-se que o único no qual a cárie é uma doença altamente endêmica é o Brasil.

Tanto nas regiões economicamente menos desenvolvidas do globo - África e Ásia p.ex., onde o consumo de açúcar permanece em geral muito baixo - quanto no mundo industrializado que adotou eficazes sistemas preventivos, os niveis de cárie de suas populações são muito baixos ou estão em processo de ativa redução(178,181,190). 
TABILA 23

SHOICE OE ATNOUE PETA CARIK OETTAL SEOUTOO

A IDNOE I A RETOA. BRASIL. ZOYA URBAMA.

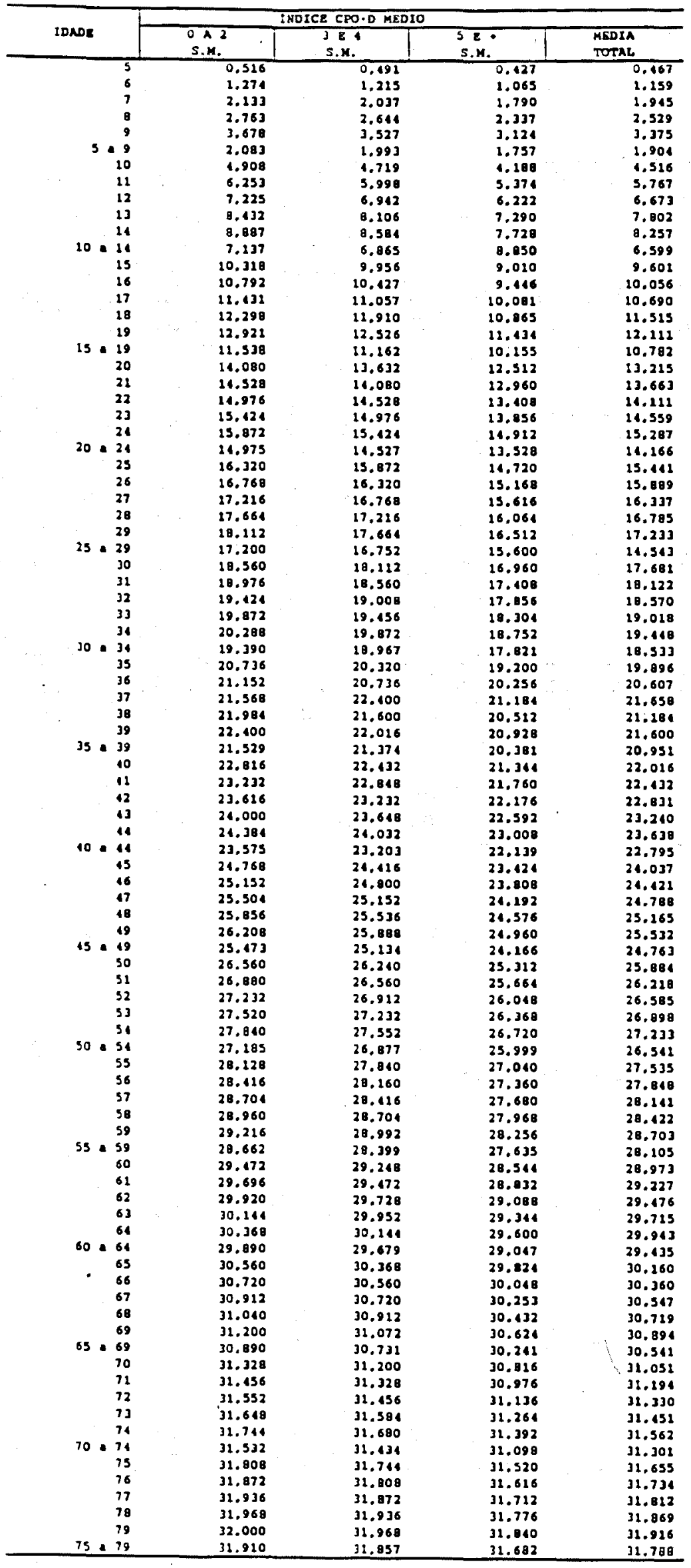


DEATES OBTURADOS E EXTRAIDOS: MLDIA POR PESSOA

SEOUTDO A IDADE E A REMDA. BRASIL. ZONA URBNAA.

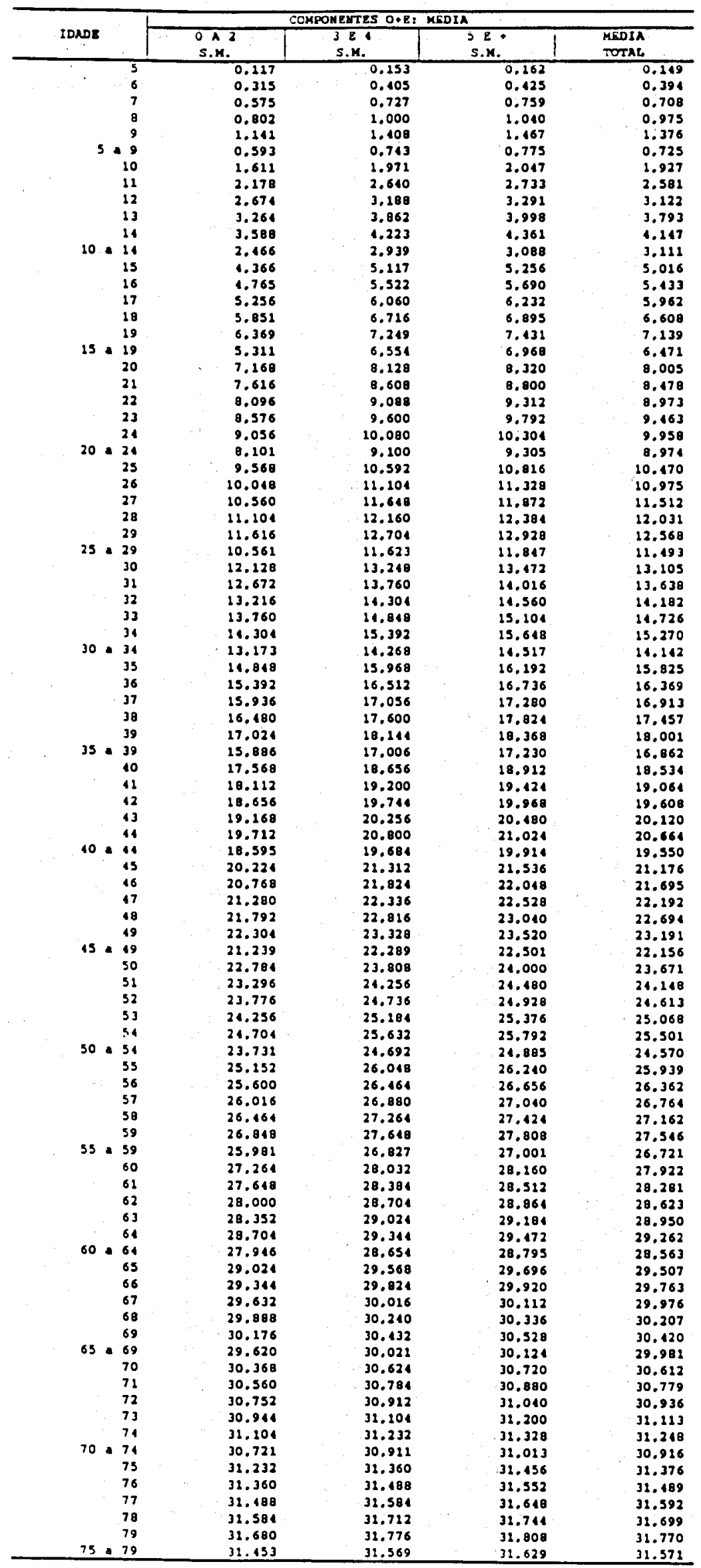


TABELA 25

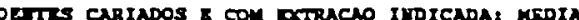

POR PESSOA SEOUNDO A IDNOE E A RETOA. BRASIL.

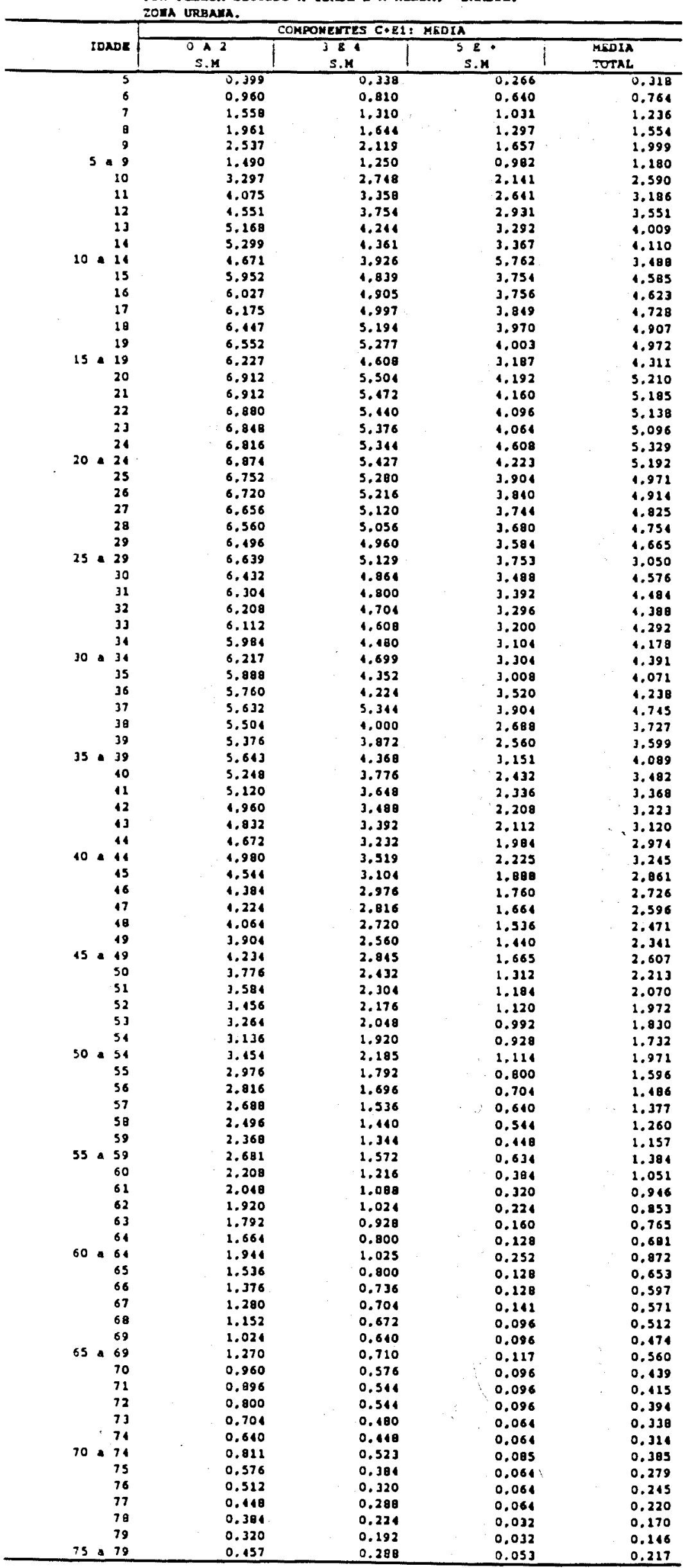


TABILA 26

TOTAL OE DEATES CPO, SEOUTDO A IDNDE

E A REUDA. BRASIL. ZOHA URBNHA.

\begin{tabular}{|c|c|c|c|c|}
\hline & & 10 DENTES CPO & & \\
\hline & 0.2 s.x. & 3.4 S.M. & Soe S.X: & TOTAL \\
\hline 5 & 269429 & 346890 & 431393 & 1025712 \\
\hline 6 & 616111 & 854405 & 1076577 & 2547393 \\
\hline 7 & 2037613 & 1411423 & 1820150 & 1299186 \\
\hline 8 & 1355227 & 1886432 & 2396927 & 5638606 \\
\hline 9 & 1822209 & 2511539 & 3235930 & 7999718 \\
\hline $3 \cdot 9$ & 5080889 & 7068728 & 8960997 & 21110614 \\
\hline 10 & 2461936 & 3443100 & 4392525 & 10297562 \\
\hline 11 & 3188111 & 1448141 & 5729281 & 133655333 \\
\hline 12 & 3704127 & 5176788 & 8669010 & 15550725 \\
\hline 13 & 1272671 & 5974511 & 7723806 & 17970989 \\
\hline 16 & 4401722 & 6181214 & 8003310 & 18589246 \\
\hline $10 \cdot 14$ & 18028568 & 25226755 & 32518732 & 75774055 \\
\hline 15 & 5002589 & 7021270 & 9133924 & 21157663 \\
\hline 16 & 5112181 & 7184412 & 9355942 & 21652535 \\
\hline 17 & 5325611 & 7492898 & 9820285 & 22638794 \\
\hline 18 & 5705522 & 8037106 & 10539637 & 24282265 \\
\hline 19 & 6016832 & 8484212 & 11132817 & 25633859 \\
\hline $15 \cdot 19$ & 27162715 & 38219796 & 19982604 & 115365115 \\
\hline 20 & 6562533 & 9240369 & 12191705 & 27993608 \\
\hline 21 & 6761222 & 9535469 & 12616884 & 28916575 \\
\hline 22 & 6968298 & 9832362 & 13014388 & 29844948 \\
\hline 23 & 7170525 & 10126906 & 13469725 & 30766156 \\
\hline 24 & 7364100 & 10409071 & 14466340 & 32239512 \\
\hline $20 \cdot 24$ & 34828579 & 49141177 & 63700043 & 149760799 \\
\hline 25 & 7549681 & 10679904 & 14230082 & 32167667 \\
\hline 26 & 7732999 & 10917489 & 14626169 & 33306657 \\
\hline 27 & 7850993 & 11122483 & 14890106 & 338633584 \\
\hline 28 & 7868853 & 11153314 & 14962749 & 33986915 \\
\hline 29 & 7809605 & $\$ 1078437$ & 14806650 & 33774691 \\
\hline $25 \cdot 29$ & 38812133 & 54903626 & 73603755 & 167399513 \\
\hline 30 & 7733785 & 10977611 & 14776620 & 33600016 \\
\hline 31 & 7618769 & 10838892 & 14613825 & 33071489 \\
\hline 32 & 7498460 & 10673258 & 14412953 & 32504671 \\
\hline 33 & 7372015 & 10498477 & 14197974 & 32068466 \\
\hline 34 & 7225612 & 10294191 & 13964277 & 31484380 \\
\hline $30=31$ & 37448641 & 53282728 & 71965648 & 162697018 \\
\hline 35 & 7067638 & 10073945 & 13683130 & 30824712 \\
\hline 36 & 6879709 & 9810036 & 13775490 & 30465243 \\
\hline 37 & 6692162 & 10209568 & 137135866 & 30545316 \\
\hline 38 & 6514197 & 9310097 & 12709153 & 28533747 \\
\hline 39 & 6314173 & 9069689 & 12393394 & 27807256 \\
\hline $35 \cdot 39$ & 33490178 & 48373335 & 66304761 & 149276274 \\
\hline 10 & 6169355 & 8822595 & 12067321 & 27059272 \\
\hline 11 & 5992950 & 8572935 & 11736756 & 26302642 \\
\hline 42 & 5818746 & 8326000 & 11424610 & 25569356 \\
\hline 13 & 5660688 & 8112943 & 11141584 & 24915215 \\
\hline 11 & 5516953 & 7900811 & 10404487 & 24310251 \\
\hline $10 \cdot 14$ & 291386692 & 41743285 & 57234758 & 128156735 \\
\hline 15 & 5376192 & 7708790 & 10631170 & 23716152 \\
\hline 46 & 5235489 & 7508671 & 10361980 & 23108140 \\
\hline 47 & 5115108 & 7337442 & 10145012 & 22597562 \\
\hline 48 & 5033413 & 7230723 & 10001390 & 22267527 \\
\hline$\therefore \quad 19$ & 4976794 & 7150576 & 9910493 & 22037863 \\
\hline $45=49$ & 25736997 & 36936203 & 51052045 & 113725244 \\
\hline so & נ3 49235 & 7075222 & 9810957 & 21809712 \\
\hline 51 & 4076435 & 2008547 & 9734920 & 21619902 \\
\hline 52 & 4805223 & 6907288 & 9610462 & 21322972 \\
\hline 53 & 1669456 & 6720830 & 9354601 & 20744967 \\
\hline 54 & 4504790 & 6484639 & 9040178 & 20029607 \\
\hline $50 \cdot 54$ & 23779438 & 31196526 & 17551196 & 105927160 \\
\hline 53 & 4339278 & 6247045 & 8722078 & 19308400 \\
\hline 56 & 4165359 & 6001134 & 8385731 & 18555224 \\
\hline 57 & 1015575 & 5782258 & 8096704 & 17894537 \\
\hline 58 & 3905285 & 5630175 & 7885857 & 17421317 \\
\hline 59 & 3820313 & 5514191 & 7725116 & 17059921 \\
\hline $55 \cdot 59$ & 20245811 & 29277804 & 10015785 & 90239100 \\
\hline 60 & 3743799 & 5404153 & 7582458 & 16729409 \\
\hline 61 & 3701933 & 5314010 & 7515170 & 16561120 \\
\hline 62 & 3569965 & 5159354 & 7236903 & 15986222 \\
\hline 63 & 3287625 & 1751555 & 6692694 & 14730874 \\
\hline 64 & 2928113 & 4227636 & 5967567 & 13123316 \\
\hline $60 \cdot 64$ & 17231435 & 24886708 & 35012798 & 77130941 \\
\hline 65 & 2592863 & 3747776 & $\$ 290897$ & 11631536 \\
\hline 66 & 2225818 & 3220688 & 4952182 & 9998607 \\
\hline 67 & 2094288 & 3027302 & 4285351 & 9407142 \\
\hline 68 & 2325765 & 3368975 & 4767690 & 10.62430 \\
\hline 69 & 2793492 & 4046600 & 5733008 & 12373180 \\
\hline $65 \bullet 69$ & 12032226 & 17411341 & 21629408 & 54072975 \\
\hline 70 & 2027518 & 2937106 & 1170124 & 9134767 \\
\hline 71 & 1997928 & 2894269 & 4113768 & 9005961 \\
\hline 72 & 1918740 & 2782409 & 3959036 & 8660185 \\
\hline 73 & 1758173 & 2552177 & 3632564 & 7941913 \\
\hline 71 & 1561138 & 2266165 & 3227977 & 7055280 \\
\hline $70 \cdot 74$ & 9263527 & 13432125 & 19102457 & 11790110 \\
\hline 75 & 1213247 & 2804710 & 2575972 & 5623929 \\
\hline 76 & 1222419 & 1774505 & 2535145 & 3532369 \\
\hline 71 & 1172882 & 1702602 & 2135196 & 5310680 \\
\hline 78 & 1072526 & 1558477 & 2229086 & 4860090 \\
\hline 79 & 950400 & 1381018 & 1977264 & 4308682 \\
\hline $73 \cdot 79$ & 5661474 & 8221311 & 11752964 & 25635749 \\
\hline DTAL & 317969303 & $4 \mathrm{H2} 304414$ & 056295951 & $: 476569702$ \\
\hline
\end{tabular}


TABELA 27

TTAL DE DETMES O.E SEGUTDO A IDAD

\begin{tabular}{|c|c|c|c|c|}
\hline = & & DENTES 0.2 & & \\
\hline & 0.2 S.M. & 3.4 S.M. & seo s.1. & Total \\
\hline 5 & 56455 & 107498 & 163214 & 327067 \\
\hline 6 & 152290 & 284802 & 129620 & 866711 \\
\hline 7 & 279806 & 314390 & 771939 & 1566135 \\
\hline 8 & 393453 & 713602 & 1066429 & 2273404 \\
\hline 9 & 565241 & 1014580 & 1513514 & 3099314 \\
\hline $5 \cdot 9$ & 1447245 & 2634651 & 3950645 & 8032741 \\
\hline 10 & Bo810s & 1438091 & 2146967 & 4393163 \\
\hline 11 & 1110460 & 1957035 & 2913531 & 5981825 \\
\hline 12 & 1370912 & 2377355 & 3527860 & 7276127 \\
\hline 13 & 2653937 & 2816479 & 1233909 & 8736326 \\
\hline 14 & 1777133 & 3042397 & 4516361 & 9335090 \\
\hline $10 \cdot 14$ & 6720547 & 11662157 & 27340626 & 35723332 \\
\hline 15 & 2116007 & 3601611 & 5320291 & 21053709 \\
\hline 16 & 2257185 & 3804760 & 5635732 & 11697705 \\
\hline 17 & 2148728 & 4106626 & 6070828 & 12626192 \\
\hline 18 & 2714507 & 4532091 & 6680522 & 13935121 \\
\hline 19 & 2965808 & 4909951 & 1233260 & 15111019 \\
\hline $15 \cdot 19$ & 12303035 & 20962047 & 30858653 & 84423735 \\
\hline 20 & 3340017 & 3509516 & 8107016 & 16956949 \\
\hline 21 & 1546002 & 5820639 & 0567020 & 17962661 \\
\hline 22 & 3766996 & 6150640 & 9050469 & 18977104 \\
\hline 23 & 3986931 & 6491606 & 9518314 & 19996851 \\
\hline 24 & 1201694 & 6802609 & $999 \operatorname{coss}$ & $2100035 \theta$ \\
\hline $20 \cdot 24$ & 18843040 & 30784011 & 15247872 & 94673923 \\
\hline 25 & 4124186 & 7127113 & 10461895 & 22015194 \\
\hline 26 & 1833896 & 7440585 & 10923341 & 23005823 \\
\hline 27 & 1815668 & 7726305 & 11320142 & 23062113 \\
\hline 28 & 1946343 & 7879218 & 11535027 & 24360788 \\
\hline 29 & 5008633 & 7967641 & 11655439 & 24831716 \\
\hline $25 \cdot 29$ & 23830925 & 38148065 & 55045846 & 117875834 \\
\hline 30 & 5053628 & 8029560 & 11737655 & 24820843 \\
\hline 31 & 5087745 & 8035730 & 11766278 & 24009752 \\
\hline 32 & 5101918 & 8032896 & 11752497 & 24000311 \\
\hline 33 & 5101618 & 0011996 & 12715810 & 24932422 \\
\hline 34 & 5094398 & 7973672 & 11652784 & 24720851 \\
\hline $30 \cdot 34$ & 25442305 & 10082853 & 58625024 & 124150183 \\
\hline 35 & 5060777 & 7916376 & 11539439 & 24516592 \\
\hline 36 & 5008263 & 7812695 & 11382652 & 24199810 \\
\hline 37 & 1944854 & 7697714 & 11210780 & 23853248 \\
\hline 30 & 1883502 & 7586005 & 11013679 & 23313186 \\
\hline 39 & 4821571 & 7474584 & 10877383 & 23173538 \\
\hline $35 \cdot 39$ & 24718760 & 39406373 & 56052933 & 119256074 \\
\hline 10 & 4750317 & 7337479 & 10892334 & 22780131 \\
\hline 11 & 1872190 & 7204147 & 10476781 & 22353218 \\
\hline 12 & 1596652 & 7075953 & $102 \notin 7091$ & 21959700 \\
\hline IJ & 1321003 & 6949246 & 10100019 & 21370268 \\
\hline 14 & 1459899 & 6845176 & 9945908 & 21250903 \\
\hline $10 \times 11$ & 23000060 & 35112002 & 51502137 & 109911199 \\
\hline 15 & 4389862 & 6720774 & 9774286 & 20892922 \\
\hline 18 & 1322942 & 6607631 & 9595973 & 20526546 \\
\hline 17 & 1267938 & 6515947 & 9447207 & 20231092 \\
\hline 10 & 1242270 & 6460533 & 9378179 & 20000907 \\
\hline 19 & 4235440 & 6463474 & 9338734 & 20017648 \\
\hline $15 \cdot 19$ & 21150153 & 32756350 & 17534378 & 101749189 \\
\hline 50 & 1223561 & 6419470 & 2302424 & 19245455 \\
\hline 51 & 1226241 & 6400576 & 9285803 & 19912623 \\
\hline 52 & 4195394 & 6340791 & 9197235 & 19741121 \\
\hline 53 & 1115631 & 6215306 & 9002745 & 19333768 \\
\hline 54 & 3997354 & 6032748 & 8726207 & 18736309 \\
\hline $50 \cdot 54$ & 20758190 & 11416971 & 15314121 & 97689576 \\
\hline 55 & 388017 & 5844937 & 0444027 & 18189138 \\
\hline 56 & 3752576 & 5612522 & 0260957 & 17565055 \\
\hline 57 & 3639534 & 5489704 & 7909497 & 17028735 \\
\hline 58 & 3568697 & 5347725 & 7732471 & 16640892 \\
\hline 59 & 3510671 & 5258567 & 7602930 & 16372168 \\
\hline $55 \cdot 59$ & 10351652 & 27563453 & 39078002 & 05793980 \\
\hline 60 & 3463319 & 5179473 & 7470465 & 26122258 \\
\hline 61 & 3446627 & 5146729 & 7431767 & 16025123 \\
\hline 62 & 3340876 & 4981637 & 7201020 & 15523532 \\
\hline 63 & 3092183 & 4604330 & 6635207 & $1435172 \theta$ \\
\hline 64 & 2767860 & 4115437 & 5942762 & 12824067 \\
\hline $60 \cdot 64$ & 16110845 & 24027325 & 34709220 & 74847190 \\
\hline 65 & 2462541 & 3649046 & 5268109 & 11379776 \\
\hline 86 & 2126120 & 3143122 & 4532790 & 9002031 \\
\hline 67 & 2007568 & 2957927 & 1265606 & 9231100 \\
\hline 68 & 2239418 & 3295737 & 1752650 & 10287835 \\
\hline 69 & 2701008 & 3963251 & 5715116 & 12380173 \\
\hline $65 \cdot 69$ & 11537485 & 17009002 & 24534352 & 53080918 \\
\hline 70 & 1965417 & 2082802 & 4157123 & 9005122 \\
\hline 71 & 1941018 & 2844011 & 4101018 & 0806047 \\
\hline 72 & 1870091 & 2734290 & 3946029 & 0351210 \\
\hline 73 & 1719063 & 2513390 & 3624130 & 7036582 \\
\hline 71 & 1329664 & 2234119 & 3221396 & 6905178 \\
\hline $70 \times 74$ & 9025253 & 13208691 & 19030493 & 12284439 \\
\hline 15 & 1220734 & 1702079 & 2570742 & 5574351 \\
\hline 16 & 1202781 & 2756653 & 2530313 & 5409747 \\
\hline 17 & 1156428 & 1687217 & 2430202 & 5273927 \\
\hline 78 & 1059643 & 1547546 & 2226042 & 4934030 \\
\hline 79 & 940896 & 1372723 & 1975277 & 4289896 \\
\hline $75 \cdot 79$ & 5500483 & 0147017 & 11733454 & 25460954 \\
\hline TOTAL & 39325087 & 372302057 & 512528932 & 1150156076 \\
\hline
\end{tabular}


TABXIA 28

TOTAL DE DUTE C.81 SEGUITD a TDADE

\begin{tabular}{|c|c|c|c|c|}
\hline & & DEATES $\mathrm{C}+\mathrm{BL}$ & & \\
\hline & 0.2 S.M. & 3.4 S.M. & $50 \cdot$ S.M. & TOTAL \\
\hline 5 & 192974 & 237392 & 268279 & 698645 \\
\hline 6 & 161121 & 569603 & 646957 & 1680681 \\
\hline 7 & 757807 & 927033 & 1048211 & 2733051 \\
\hline 8 & 961774 & 1172850 & 1330497 & 3465122 \\
\hline 9 & 1256967 & 1526999 & 1716407 & 1500373 \\
\hline $5 \cdot 9$ & 3633644 & 0433877 & 5010352 & 13077873 \\
\hline 10 & 1653831 & 2005010 & 2245558 & 5904399 \\
\hline 11 & 2077651 & 2490306 & 2815750 & 7383707 \\
\hline 12 & 2333216 & 2799433 & 3141950 & 8274599 \\
\hline 13 & 2618734 & 3128032 & 3487897 & 9234683 \\
\hline 14 & 2624589 & 3141817 & 3406049 & 9253356 \\
\hline $10 \cdot 14$ & 13308022 & 13564597 & 15178104 & 40050723 \\
\hline 15 & 2885762 & 3412560 & 3805633 & 10103954 \\
\hline 16 & 2854996 & 3379643 & 3720190 & 9954829 \\
\hline 17 & 2876883 & 3366272 & 3749457 & 10012612 \\
\hline 18 & 2991015 & 3505015 & 3851134 & 10347144 \\
\hline 19 & 3051024 & 3574260 & 3897557 & 10522840 \\
\hline $15 \cdot 19$ & 14659679 & 17257750 & 19023951 & 50911380 \\
\hline 20 & 3221116 & 3730053 & 4064609 & 11036659 \\
\hline 21 & 3218220 & 3705030 & 4049864 & 10973914 \\
\hline 22 & 3201202 & 3601721 & 3904921 & 10867844 \\
\hline 23 & 3203594 & 3635300 & 3950411 & 10769305 \\
\hline 21 & 3262406 & 3606463 & 4170285 & 11239154 \\
\hline $20 \cdot 24$ & 15986539 & 18360167 & 20540170 & 54086876 \\
\hline 25 & 3123495 & 3552791 & 3776187 & 10452473 \\
\hline 26 & 3099103 & 3498903 & 3702828 & 10300833 \\
\hline 27 & 3035329 & 3396178 & 3569964 & 10001471 \\
\hline 28 & 2922309 & 3276096 & 3427721 & 9626127 \\
\hline 29 & 2800971 & 3110793 & 3231211 & 9112975 \\
\hline $25 \times 29$ & 14981208 & 16834761 & 17707910 & 19523879 \\
\hline 30 & 2680157 & 2940051 & 3038965 & 8667173 \\
\hline 31 & 2531024 & 2803162 & 2847547 & 8281733 \\
\hline 32 & 2396543 & 2611362 & 2660455 & 7698360 \\
\hline 33 & 2267399 & 2486483 & 2482163 & 7236044 \\
\hline 34 & 2131214 & 2320819 & 2311493 & 6763526 \\
\hline $30-34$ & 12006336 & 13199875 & 13340624 & 38516835 \\
\hline J3 & 2006860 & 2157569 & 2143690 & 6300120 \\
\hline 36 & 1873446 & 1990341 & 2393846 & 6265633 \\
\hline 37 & 1747508 & 2411854 & 2532806 & 6692168 \\
\hline 30 & 1630995 & 1724092 & 1665474 & 5020561 \\
\hline 39 & 1522601 & 1595105 & 1516012 & 6633718 \\
\hline 35 a 39 & 8781410 & 9006961 & 10251828 & 28920200 \\
\hline 10 & 1419030 & 1485116 & 1374987 & 4279818 \\
\hline 11 & 1320760 & 1360788 & 1259975 & 3949521 \\
\hline 12 & 1222094 & 1250047 & 1137515 & 3609657 \\
\hline 43 & 1139685 & 1163697 & 1042564 & 3344946 \\
\hline 44 & 1057054 & 1063635 & 930579 & 3059268 \\
\hline $10 \cdot 14$ & 6158632 & 6331283 & 5752621 & 18212536 \\
\hline 45 & 986330 & 980017 & 856984 & 2823230 \\
\hline 16 & 912547 & 901041 & 766007 & 25795904 \\
\hline 47 & 817170 & 821195 & 697005 & 2366170 \\
\hline 48 & 791143 & 770190 & 625212 & 2186545 \\
\hline 49 & 711354 & 707103 & 571759 & 2020216 \\
\hline $15 \cdot 49$ & 1278543 & 1279841 & 3517667 & 11976054 \\
\hline so & 699972 & 655752 & 500533 & 1864257 \\
\hline 51 & 650191 & 607970 & 149117 & 1707279 \\
\hline 52 & 609828 & 558497 & 113226 & 1581531 \\
\hline 53 & 553819 & 505114 & 351936 & 1411199 \\
\hline 54 & 507436 & 151891 & 313970 & 1273298 \\
\hline $50 \cdot 51$ & 3021267 & 2779555 & 2036782 & 7837584 \\
\hline 53 & 159105 & 402109 & 258050 & 1119263 \\
\hline 56 & 112783 & 361613 & 215773 & 990169 \\
\hline 57 & 376040 & 312554 & 187207 & 075802 \\
\hline 38 & 336588 & 282450 & 153386 & 772425 \\
\hline 39 & 309612 & 255625 & 122487 & 687751 \\
\hline $35 \cdot 59$ & 1891158 & 2614351 & 936903 & 1415112 \\
\hline 60 & 280480 & 224680 & 101993 & 607153 \\
\hline 61 & 255306 & 197282 & 83409 & 535997 \\
\hline 62 & 229089 & 177717 & 55884 & 462690 \\
\hline 63 & 195413 & 147217 & 36407 & 379117 \\
\hline 64 & 160445 & 112198 & 25806 & 290149 \\
\hline $60 \cdot 61$ & 1120789 & 859384 & 303578 & 2203751 \\
\hline 65 & 130322 & 90730 & 22708 & 251759 \\
\hline 66 & 99698 & 77566 & 19392 & 196656 \\
\hline 67 & 86720 & 69376 & 19945 & 276041 \\
\hline 68 & 06317 & 73239 & 15060 & 174596 \\
\hline 69 & 91684 & 83349 & 17972 & 193005 \\
\hline $65 \cdot 69$ & 491741 & 102759 & 95037 & 992037 \\
\hline 70 & 62131 & 54223 & 12991 & 129346 \\
\hline 71 & 56909 & 50258 & 12749 & 119917 \\
\hline 72 & 18630 & 18119 & 12207 & 108973 \\
\hline 73 & 39110 & 38787 & 7434 & 85331 \\
\hline 71 & 31475 & 32047 & 6581 & 70102 \\
\hline $70 \cdot 74$ & 238275 & 223434 & 51962 & 513671 \\
\hline 75 & 22514 & 21831 & 5230 & 19575 \\
\hline 76 & 19637 & 17852 & 5132 & 12622 \\
\hline 77 & 16453 & 15385 & 1915 & 36753 \\
\hline 78 & 12883 & 10931 & 2215 & 26059 \\
\hline 79 & 9504 & 8294 & 1987 & 19786 \\
\hline $75=79$ & 00991 & 74291 & 19510 & 174795 \\
\hline TUTAL & 98641216 & 110002391 & 113767019 & 322113626 \\
\hline
\end{tabular}




\section{GRÁFICO VI}

INDICE CPO-D E COMPONENTES POR GRUPO ETARIO-BRASIL, ZONA URBANA ( $N^{\circ}$ de dentes afetados)

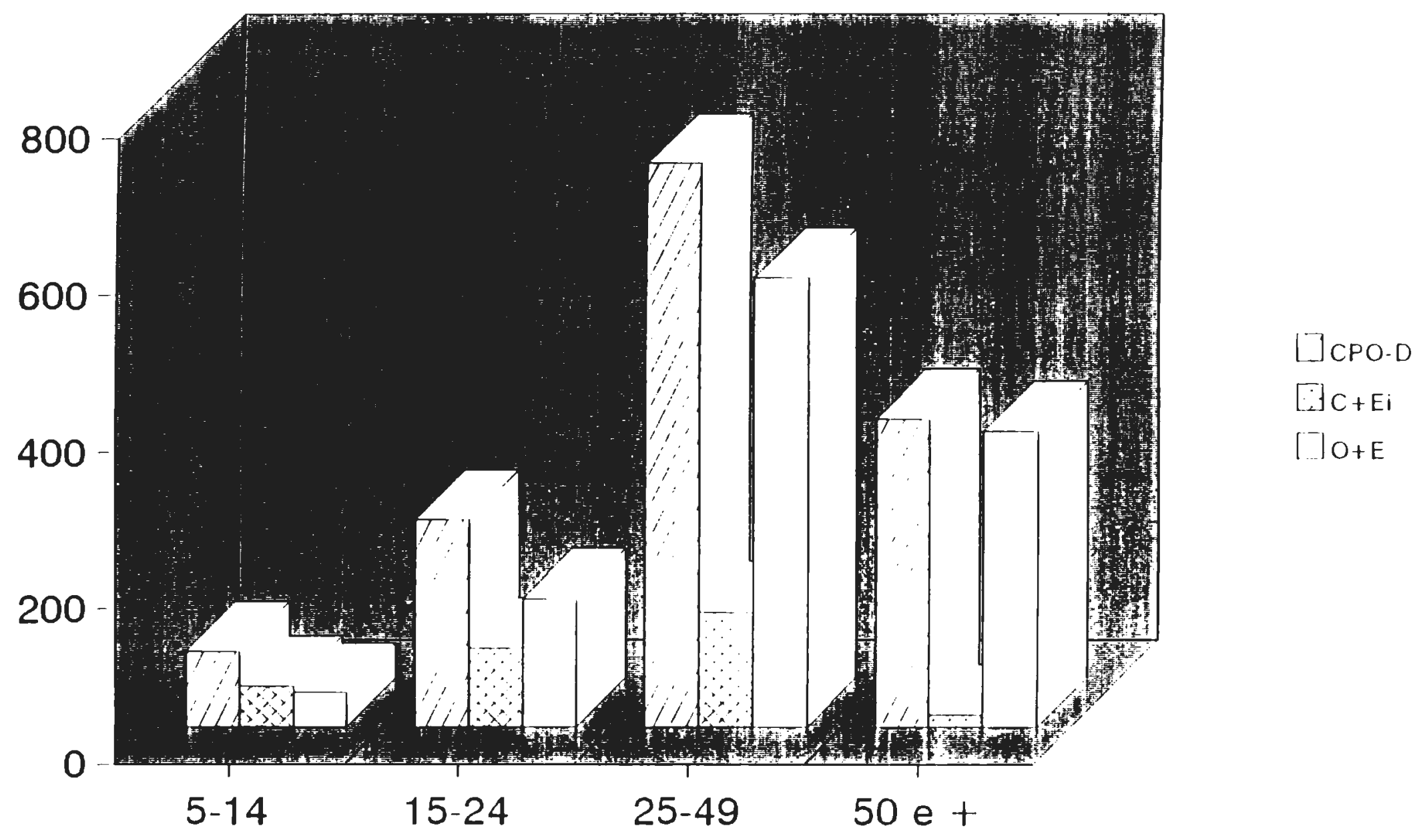




\section{GRÁFICO VII}

INDICE CPO-D EM ADOLESCENTES E ADULTOS, EM DOIS ESTUDOS INDEPENDENTES BRASIL - Zona urbana

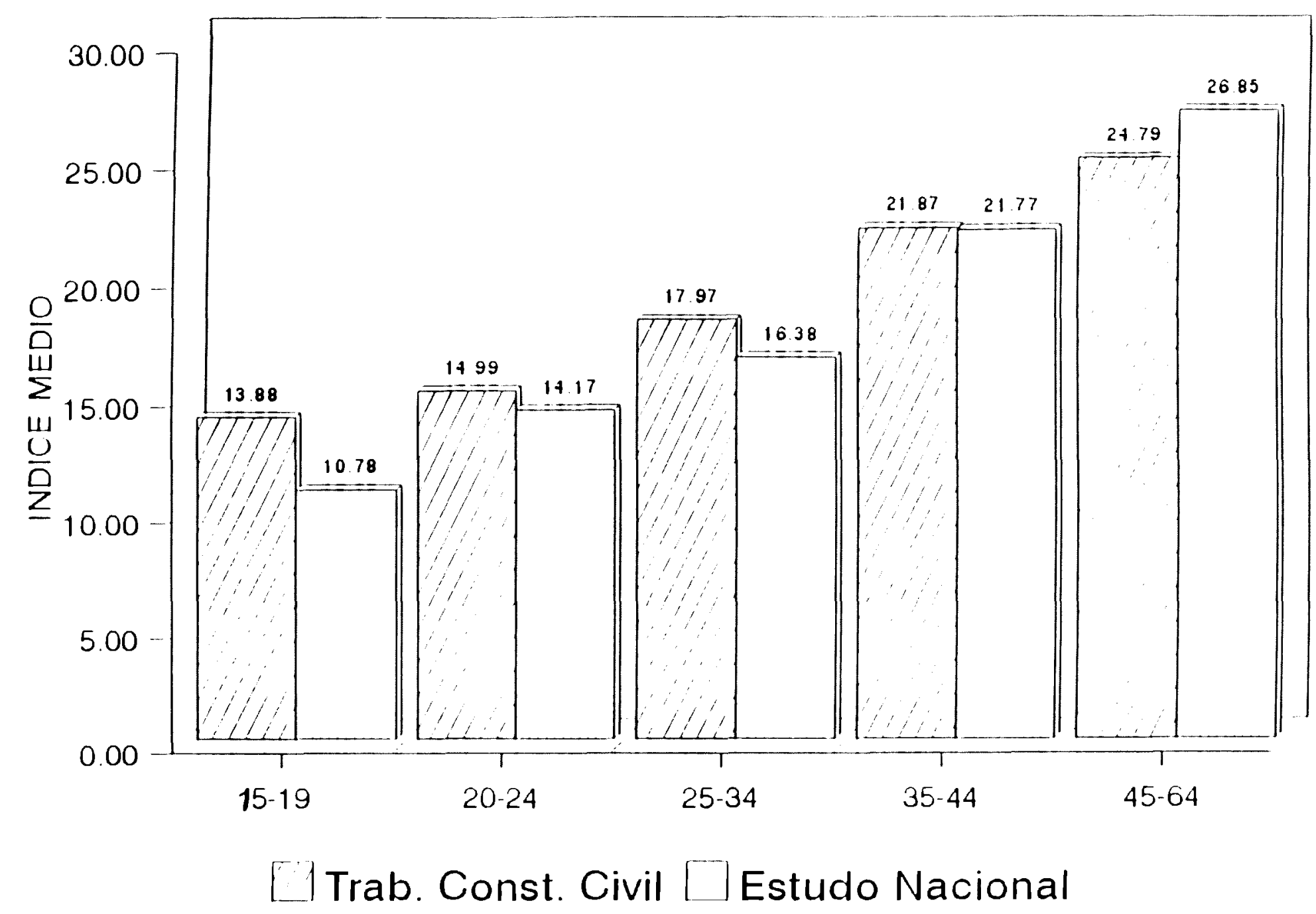

Fontes: Bibliografias 34, 141, 226 


\section{GRÁFICO VIII}

PAISES COM ALTO, MÉDIO E BAIXO ÍNDICE CPO-D EM CRIANCAS

AOS 12 ANOS DE IDADE

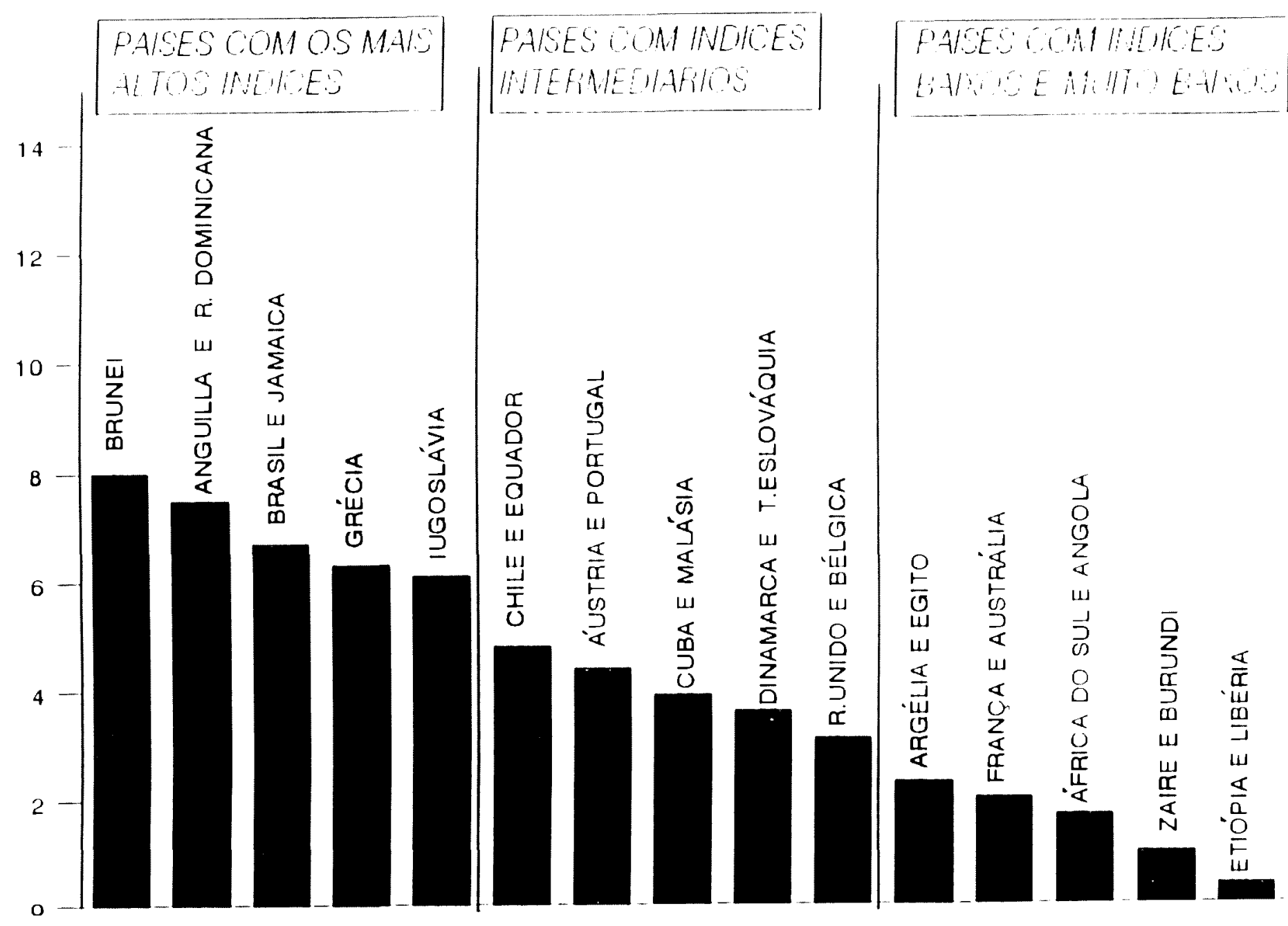




\section{GRÁFICO IX}

ÍNDICE CPO-D AOS 12 ANOS DE IDADE NOS PAISES MAIS POPULOSOS

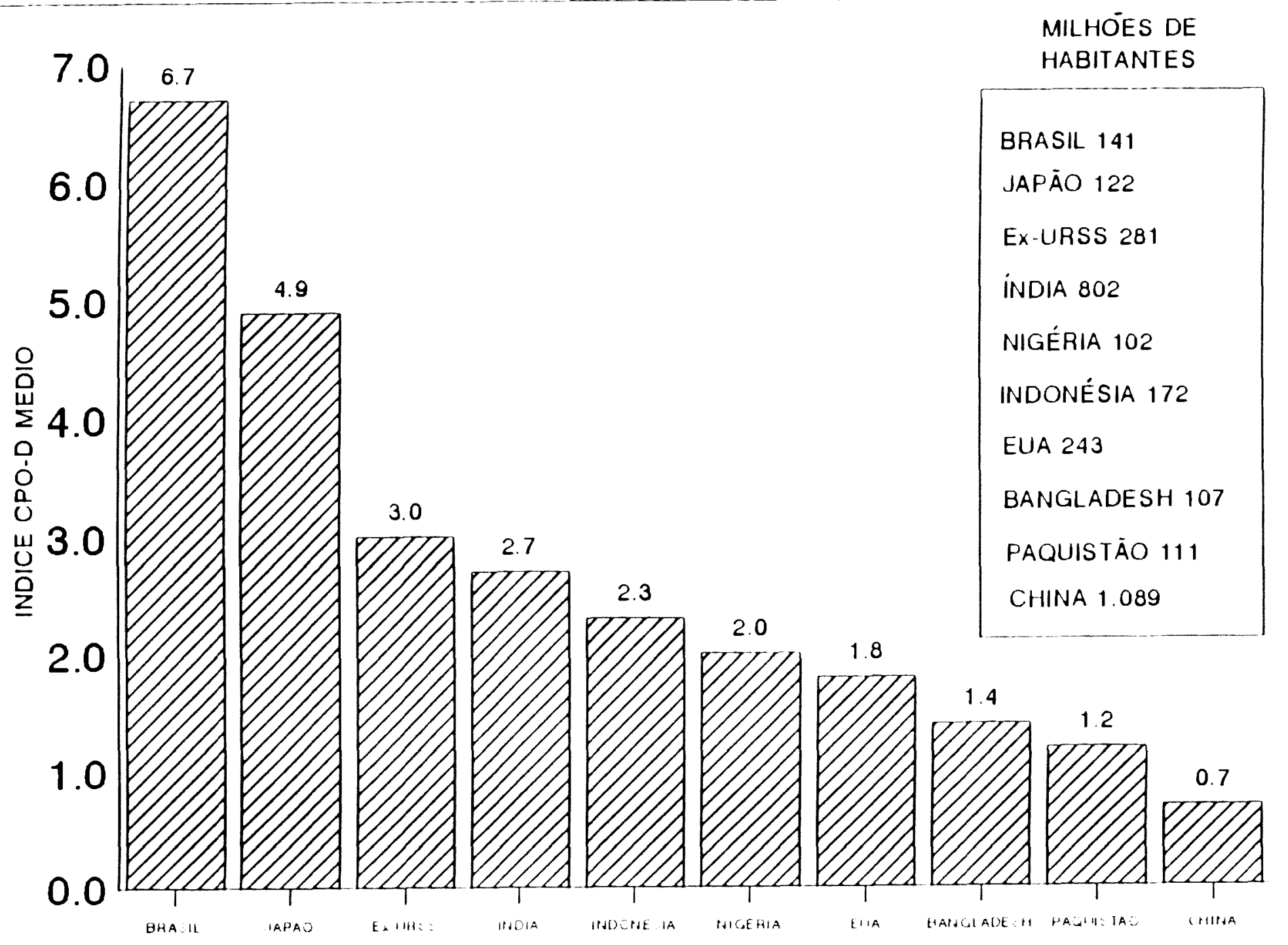

Fontes: Bibliografias 185, 239, 240 


\section{: 7.5. Procura de Atendimento}

- percentual e o número de pessoas, por idade e renda, que receberam atendimento odontológico durante o período de um ano, está na Tabela 29, com base nas Tabelas VI e VII do Anexo V.

Incluem-se nesta categoria todos os que compareceram a uma clínica ou consultório odontológico público ou privado pelo menos uma vez no ano, seja para receber cuidados de urgência, seja como parte de um tratamento continuado.

Os padrões de procura obtidos neste estudo podem ser considerados como relativamente altos, igualando ou superando $50 \%$ da população urbana de 5 a 36 anos e se mantendo num patamar acima de 288 nas demais idades. Estas proporções aproximam-se das constatadas em países bem mais desenvolvidos: nos Estados Unidos cerca de 508 da população recebeu pelo menos uma consulta no ano em 1982; na Suécia no mesmo período em torno de $67 \%$ das pessoas receberam tratamento(84,181). Ainda que uma parcela significativa e não mensurada de pessoas possa ter recebido uma só consulta - o que não necessariamente significa que tenham recebido cuidados adequados - dificilmente poder-se-ia esperar uma proporção superior no caso brasileiro onde a maioria não dispõe de recursos para pagar os preços cobrados nas clínicas particulares. Acrescente-se que as pessoas costumam procurar o odontólogo em geral só quando têm algum problema aparente, ou seja, não vão porque querem e sim porque precisam.

Para o conjunto da população estudada, aproximadamente $54 \%$ frequentou algum consultório no ano. É interessante observar que esta proporção é bastante superior à encontrada em outros estudos nacionais.

A Fundação IBGE(108) incluiu a mesma pergunta quando da Pesquisa Nacional por Amostra de Domicílios -PNAD- efetivada em 1981, concluindo que 20,3 milhōes de brasileiros buscaram atendimento no ano, representando cerca de $17 \%$ da população total. Uma vez excluido $\circ$ grupo de 0 a 4 anos $\circ$ indicador sobe para 19,48. Considerando-se a população urbana de 5 a 79 anos, ou seja, a que pode ser de fato comparada com o presente estudo, temos um total de 16,7 milhões de pessoas atendidas correspondendo a $24,45 \%$ do total (na zona rural somente 11,88 )

A Pesquisa Nacional sobre Saúde e Nutrição realizada em 1989 pelo INAN, Fundação IBGE e IPEA, estimou que cerca de 13,48 da população "procurou atendimento por problema dentário nas últimas duas semanas"(119,120). Esta proporção foi de 25,78 entre os que declararam ter tido problema dentário nas duas semanas (um em cada dez responderam afirmativamente a esta questão, indicando a prevalência de danos realmente sentidos pelas pessoas. Destes, $53 \%$ disseram ainda te-los no dia da entrevista), e de 8,38 entre os que achavam não ter problemas imediatos.

Por último, há o estudo de $1991(141)$ junto a operários da construção civil, ou seja, uma população adulta de baixa renda 
residente em zona urbana: 27,88 "consultaram dentista no último ano".

Segundo a Tabela $29,7,6$ milhões de pessoas de baixa renda ( $37 \%$ do total de 5 a 79 anos nesta faixa econômica), 14,6 milhões de renda média $(48,68)$ e 28,3 milhōes de renda alta $(65,58)$ foram a consultório em 1989.

Uma explicação provável para o fato de que os resultados deste estudo tenham se situado bastante acima dos demais, está no fato de que as perguntas neste caso foram feitas por odontólogos paralelamente à realização do exame bucal, ao contrário dos outros nos quais esta tarefa cabia a um entrevistador comum que acrescentava o quesito sobre 0 atendimento a um grande número de outros sobre condiçōes financeiras, de trabalho, etc. Assim, no Levantamento Epidemiológico em principio a tendência das pessoas teria sido de superestimar sua frequência a consultórios dentários, ocorrendo o oposto nas pesquisas do IBGE e do INAN. No estudo do SESI o quesito em causa foi formulado nas mesmas condições do Levantamento do Ministério da Saúde e seu resultado embora ainda superior apresenta maior similaridade ao obtido para a faixa de menores salários: respectivamente 28 e $37 \%$.

Os maiores percentuais de procura pertencem ao grupo de 5 a 9 anos, com 65,78 ou 7,3 milhöes de crianças. Individualmente o maior contingente de clientes - 1,475 milhōes - refere-se à idade de 11 anos. 298 da clientela odontológica tem entre 5 e 14 anos; 148 de 15 a 19 anos; $61 \%$ é de adultos entre 25 e 49 anos e $10 \%$ tem 50 anos ou mais. Neste panorama, é importante ressaltar que 41,68 são crianças ou adolescentes ( 5 a 19 anos), 0 período em que 0 ataque de cărie é mais agudo. Medidas preventivas e educativas eficazes que possam ser aplicadas ou comunicadas com rapidez e de preferência em uma só consulta, certamente podem ser de grande ajuda em uma situação como a aqui diagnosticada.

As pessoas de renda mais alta são claramente predominantes nas salas de espera dos consultórios dentários brasileiros, superando de maneira sistemática os demais estratos econômicos.

As diferenças por renda aumentam com a idade: entre 5 e 9 anos a proporção de pacientes com renda familiar superior a cinco salários supera em 1,57 vezes a de mais baixa renda, ao passo que entre 50 e 54 anos esta distância é de 2,14 vezes e entre 75 e 79 anos chega a 2,82 vezes. Na média geral, de cada 1.000 pacientes, 151 são de baixa renda, 289 de renda média e 560 de renda alta. Quanto maior a idade mais se distanciam os grupos de renda que comparecem às clínicas odontológicas: de 10 a 14 anos por exemplo, essa relação é de $161-295-544$, enquanto que entre 60 e 64 anos passa a ser de 123 - 271 - 606 pacientes. 
TABELA 29

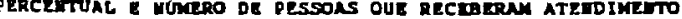

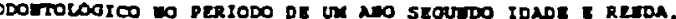

ESTIMATIVAS PNeA 1989. BRUSIL, zOMA URAMA.

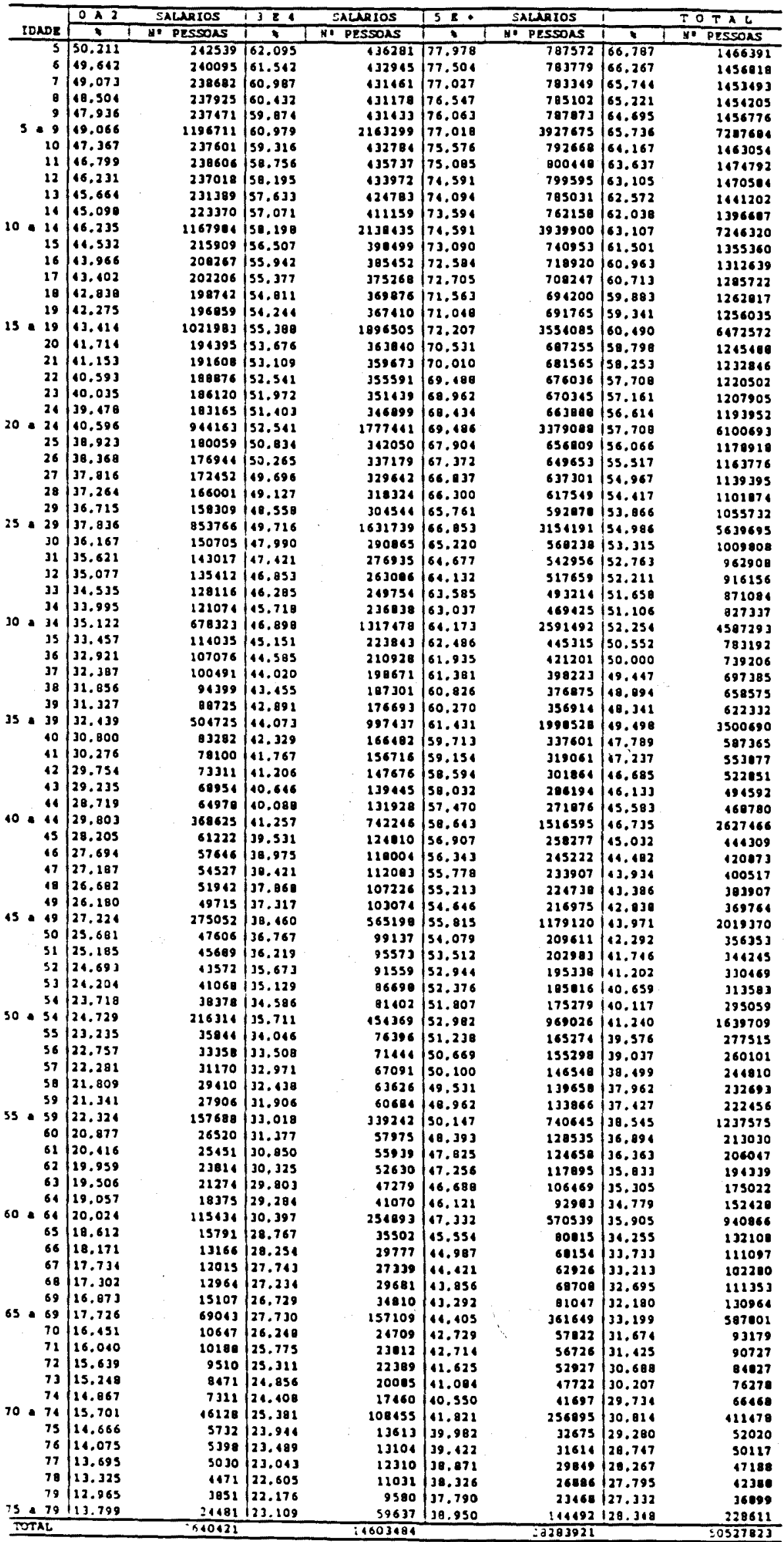




\section{: 7.6. Necessidade e Uso de Próteses Totais}

Nessa área o Levantamento Epidemiológico limitou-se ao exame das pessoas de 15 anos e mais que necessitavam, usavam ou estavam livres de próteses totais ("dentaduras"), excluindo todo e qualquer outro tipo de aparelhos (unitários, parciais, móveis, etc.). Os critérios utilizados para

Identificar a necessidade de prótese em um ou em ambos os maxilares foram quatro: (a) ausência total de dentes, (b) posse de prótese, mas nāo a estava usando no momento do exame, (c) presença de qualquer número de dentes, mas indicados para extração, (d) presença de no máximo três dentes, hígidos ou não, por maxilar.

Os resultados, com as estimativas para a população de 15 a 79 anos, encontram-se nas tabelas $30 \mathrm{e} 31$, e nos referenciais estatisticos do Anexo $V$, Tabelas VIII e IX. As variáveis independentes idade e renda tem um elevado poder de explicação sobre a variável dependente $\left(R^{2}=0,96\right.$, conforme Tabela IX)) estudada demonstrando a adequação do modelo de análise.

No conjunto, cerca de 718 da população de adolescentes e adultos está livre de próteses totais, ou seja, permanece com um número de dentes que lhe permite manter uma eficiência mastigatória integral ou limitada. Mas esta condição é perdida por uma proporção cada vez maior de pessoas à medida em que a idade avança: 90\% aos 26 anos permanece isento de próteses totais, entre 32 e 33 anos já são 808 , aos 46 anos são 508 e aos 66 anos já restam somente 108 das pessoas.

Estima-se que 20,97 milhões de residentes em áreas urbanas necessitam ou possuem pelo menos uma "dentadura", praticamente 3 em cada $10(29,48)$ dos que, entre 15 e 79 anos, vivem em cidades. Há uma forte concentração nos grupos de terceira idade. $699 \mathrm{mil}$ ou 3,38 do total têm entre 15 e 24 anos; 9,5 milhões ou 458 têm entre 25 e 49 anos e os demais 10,8 milhões ( $51 \%$ ) possui 50 anos ou mais. A distribuição da população urbana segundo estes três grupos etários é, respectivamente, de 30,51 e 198 .

A partir dos 25 anos aproximadamente a síndrome das extraçōes em massa começa a manifestar-se fazendo com que as próteses se tornem cada vez mais uma necessidade, seja para manter a funcionalidade, seja para devolver a estética perdida.

- Levantamento Epidemiológico, com base apenas na amostra populacional examinada, constatou que aproximadamente sete em cada dez adultos que não mais têm dentes em um ou em ambos os maxilares já colocaram uma prótese substitutiva.

As camadas de mais baixa renda estão mais sujeitas ao uso de próteses do que as de renda mais alta, notando-se que a distância entre estas extremidades tende a estreitar-se ao longo da vida. Assim, aos 25 anos por exemplo o percentual de necessidade ou uso de próteses dos que ganham 5 ou mais salários supera em 4 vezes à dos que percebem não mais que 2 salários, reduzindo-se a diferença 
para pouco mais que 2 vezes aos 35 anos e 1,2 vezes aos 60 anos, para virtualmente igualar-se após os 75 anos (Tabela 31).

Os índices relacionados à prótese total de acordo com este estudo são muito elevados no Brasil (em pesquisa no Distrito Federal constatou-se uma situação menos grave(138)), revelando tanto por parte da população adulta quanto dos Cirurgiões-Dentistas e dos que exercem empiricamente a profissão uma tendência ao fatalismo que a quase todos conduz a aceitar como uma consequência natural da vida a remoção total dos dentes e na maioria dos casos sua substituição por elementos artificiais que permitam pelo menos mastigar e sorrir. Ainda que as razōes de ordem financeira sejam predominantes - as extrações e as "dentaduras" são, afinal, a solução mais barata - é evidente que uma mudança coletiva na atitude dos profissionais e ações educativas persistentes no sentido de conduzir a um maior sentimento de preservação da dentição natural, devem ser tentadas com grande ênfase, tentando reverter o critico quadro epidemiológico que neste setor caracteriza o país. 
TABELA 30

PERCTUTUAL E YINERO DE PESSOAS GIVRES DE PROTESE TOTAL

\begin{tabular}{|c|c|c|c|c|c|c|c|c|c|}
\hline \multirow{2}{*}{\multicolumn{2}{|c|}{ IDNDE }} & \multirow{2}{*}{\multicolumn{2}{|c|}{ A 25.4}} & \multirow{2}{*}{\multicolumn{2}{|c|}{$\frac{E+s . n}{\text { No. }}$}} & \multirow{2}{*}{\multicolumn{2}{|c|}{$58 \cdot 5 . x .1$}} & 70 & DTAL \\
\hline & & & & & & & & 1. & \\
\hline & 5 & 7.400 & 472233 & 99.326 & 700467 & 99.023 & 1011960 & 99.131 & $32 \overline{8060}$ \\
\hline & 16 & 6.587 & 157934 & 98,880 & 601303 & 98.967 & 990139 & 98.876 & 2128976 \\
\hline & 17 & 0.669 & 415714 & 98,323 & 686297 & 99.997 & 974109 & 98.509 & 2006120 \\
\hline & $\begin{array}{l}18 \\
19\end{array}$ & $\begin{array}{l}91.617 \\
93.524\end{array}$ & $\begin{array}{l}439104 \\
433507\end{array}$ & $\begin{array}{l}97.656 \\
96.801\end{array}$ & $\begin{array}{l}659000 \\
636202\end{array}$ & $\begin{array}{l}9.913 \\
9.716\end{array}$ & $\begin{array}{l}969210 \\
970994\end{array}$ & $\mid \begin{array}{l}98.032 \\
97.447\end{array}$ & $\begin{array}{l}2067313 \\
2062604\end{array}$ \\
\hline 254 & 19 & 05.595 & 2230092 & 98.225 & 3363269 & 99.083 & 4916311 & 96.999 & 10529671 \\
\hline & 10 & .301 & 430139 & 93.999 & 650726 & 99.941 & 973822 & 98.107 & 2054687 \\
\hline & 21 & 0.983 & 123616 & 95.013 & 603461 & 90.904 & 963634 & 96.999 & 2030711 \\
\hline & 22 & 9.571 & 116766 & 93.924 & 635665 & 98.451 & 957811 & 95.049 & 2010212 \\
\hline & 3 & 0.070 & 109432 & 92.736 & 627089 & 97.807 & 950733 & 94.042 & 2987254 \\
\hline & 24 & .402 & 101219 & 91.450 & 617161 & 97.055 & 241544 & 92.935 & 1959954 \\
\hline 20 & 14 & 9.484 & 2081201 & 93.034 & 3174102 & 98.149 & 1707545 & 05.019 & 10042040 \\
\hline & 13 & 1.811 & 392338 & 90.071 & 606067 & 96.195 & 930457 & 91.731 & 1928862 \\
\hline & 16 & .081 & 393057 & 80.600 & 594331 & 95.231 & 18292 & 90.132 & 3680 \\
\hline & 17 & 1.236 & 370480 & 07.012 & 577364 & 91.160 & 897869 & 09.011 & 1045692 \\
\hline & 8 & 10 & 353439 & 05.399 & 553353 & 92.997 & 66217 & 07.561 & 1713000 \\
\hline & 19 & 77.377 & 333637 & 03.676 & 324796 & 01.732 & 827021 & 85.996 & 157 \\
\hline 25 & & 81.230 & 1832932 & 87.014 & 2855910 & 94.103 & 1439057 & 89.003 & 9128699 \\
\hline & 10 & .352 & 985 & 1.876 & 496247 & & 787378 & 84.319 & 7610 \\
\hline & 1 & 1.260 & 294171 & 0.004 & 167217 & les. & 347 & 02.634 & 7862 \\
\hline & 12 & 1.134 & 271606 & 8.084 & 438310 & 07.380 & 705311 & 00.025 & 1118258 \\
\hline & 3 & 8.950 & 253787 & 6.080 & 410121 & 05.753 & 181 & 78.956 & 1389 \\
\hline & 14 & 66.723 & 237635 & 73.997 & 383334 & 84.049 & 3990 & 77.021 & 6967 \\
\hline 30. & 4 & .255 & 1376185 & 78.155 & 2195559 & 97.419 & 3530241 & 00.090 & 7101986 \\
\hline & 15 & 1.150 & & 71.879 & 356351 & 02.265 & 272 & 75.024 & 1162325 \\
\hline & 16 & .161 & 202179 & 69,712 & 329002 & 80.100 & $5(60) 31$ & 72.971 & 113 \\
\hline & 17 & .836 & 185660 & 67.199 & 304636 & 92 & 509169 & 70,865 & 166 \\
\hline & 18 & .189 & 170357 & .127 & 05 & 76.192 & 941 & 60.771 & 926303 \\
\hline & 19 & .124 & 156 & 2.961 & 174 & 21.111 & 34 & 66.518 & 856330 \\
\hline $15 *$ & 19 & 1.030 & 934021 & 67.700 & 1532169 & 78.590 & 2557047 & 71.026 & 5023237 \\
\hline & 0 & .718 & 112628 & 60.615 & 319 & 2.334 & 957 & 161.285 & \\
\hline & 1 & 0.366 & 129925 & 58.301 & 218766 & 70.177 & 516 & 162.019 & 208 \\
\hline & 2 & & 118225 & 53.945 & 200190 & 71 & $\mathrm{BO}$ & 27 & 12 \\
\hline & 13 & .604 & 107563 & 53 & 183790 & 30 & & 37.412 & 615510 \\
\hline & 1 & 235 & 97820 & 51.192 & 170 & 50 & 165 & 55.080 & 566456 \\
\hline 10 & 14 & 10.200 & 396261 & 56.113 & 1010011 & 60,131 & 1761983 & 59.910 & 180 \\
\hline & 15 & 10.802 & 80739 & 48.000 & 151100 & 61.110 & 189 & 737 & 520328 \\
\hline & 16 & 30 & 80243 & 16.127 & 100567 & 01 & 33 & 387 & 476743 \\
\hline & 17 & .213 & 72689 & 14.055 & 128519 & 56.148 & 717 & 40.037 & 437 \\
\hline & 10 & 3.968 & 68126 & 5 & $\$ 18063$ & 31.078 & & 15.691 & \\
\hline & 19 & 1.729 & 60252 & 39.355 & 200703 & 51. & 73 & 356 & 29 \\
\hline 45. & 19 & 8.428 & 368050 & 11.227 & 649952 & 56.592 & 1195331 & 48.199 & 228 \\
\hline & 0 & .532 & 54715 & 37.039 & 99870 & 19.315 & & 41.034 & \\
\hline & 1 & 27.381 & 49673 & 34.732 & 91702 & 6.933 & & 34 & \\
\hline & 2 & & 10611 & 2.500 & 03115 & & & 459 & \\
\hline & 3 & 38 & 19129 & 0.288 & 30 & 6 & & 215 & \\
\hline & 4 & 21.256 & 30394 & & 86186 & 39.851 & 134928 & 32.007 & 08 \\
\hline & 1 & 25,477 & 222053 & 0 & 415924 & & & 136.611 & 878 \\
\hline & 3 & & 29034 & 6.0 & 58348 & & se & 29.039 & 209240 \\
\hline & 6 & & 1 & 910 & 31044 & & & 718 & \\
\hline & 1 & $\theta$ & 21909 & & 14637 & & 450 & 25.616 & 88 \\
\hline & 8 & & 10909 & & 2219 & & 17 & 31 & \\
\hline & 9 & 1 & & & 1469 & & & 21.675 & 120030 \\
\hline & 9 & 15.911 & 122590 & 2.164 & 19 & & 490365 & 25.872 & 830680 \\
\hline & 0 & 10.080 & & 8.324 & 30162 & 149 & so & 784 & \\
\hline & 1 & $9,1+1$ & 1 & & 26175 & & & 61 & \\
\hline & 2 & 093 & 6 & 158 & 89 & & & & 22 \\
\hline & 3 & Q11 & 1 & & 85 & & & & \\
\hline & 4 & 5.687 & 83 & & 25 & & 30 & 946 & 738 \\
\hline 60 & 1 & 0.350 & 10191 & 13.254 & 36 & & 273116 & 16.514 & \\
\hline & 35 & & 3932 & 319 & 10550 & 01 & 1620 & & \\
\hline & 36 & & & & 55 & & & & \\
\hline & 37 & & & & 980 & & 12 & 87 & \\
\hline & & & & & 435 & & So & 151 & 25377 \\
\hline & 9 & & 118 & 201 & 111 & & & 312 & 80 \\
\hline $85=6$ & 9 & 2.931 & 1415 & 119 & 34039 & & 100662 & & 151927 \\
\hline & & & 648 & 161 & 2976 & & & & 15394 \\
\hline & & & 120 & & 49 & 307 & 9704 & 106 & 37 1237 \\
\hline & 12 & & & 825 & 614 & & 7712 & .469 & \\
\hline & & & 150 & . J51 & 1092 & & 5777 & 19 & 7018 \\
\hline & 1 & & 81 & 972 & 695 & 020 & 1142 & 2.200 & 1918 \\
\hline $70 a 7$ & . & 331 & 1560 & & 8626 & & 39105 & 691 & 49290 \\
\hline & & & 39 & & 387 & & 2650 & 731 & 3076 \\
\hline & 8 & & 22 & & 262 & 94 & 2000 & 1,356 & 2364 \\
\hline & 17 & & 12 & & 160 & & 1573 & & 1753 \\
\hline & & & 6 & & 102 & & 1121 & 8006 & 1229 \\
\hline & & & 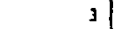 & & 58 & & 960 & 0,762 & 1029 \\
\hline & & .048 & 0 & 0.379 & & & 8393 & 1.172 & 9451 \\
\hline & & & 7 & & 228 & & 6557 & & 121 \\
\hline
\end{tabular}


TABETA 31

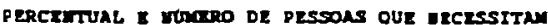

E/OU possuix peOTESE TOTAL SEOUTOO A IONDE

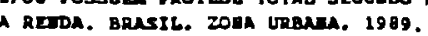

\begin{tabular}{|c|c|c|c|c|c|c|c|c|c|}
\hline \multirow{2}{*}{\multicolumn{2}{|c|}{ IDADE }} & \multicolumn{2}{|r|}{$0 \wedge 25.4$} & & \multirow{2}{*}{$\frac{38+S . M !}{M 0 .}$} & \multirow{2}{*}{\multicolumn{2}{|c|}{$\frac{58+5.4 .1}{1 \text { No. }}$}} & 507 & $T \wedge L$ \\
\hline & & 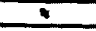 & ㅂo. & 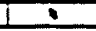 & & 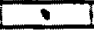 & & \pm & No. \\
\hline 1 & $\sqrt{5}$ & 2.600 & 12606 & 0.674 & 4753 & .177 & 1794 & 0.869 & 1915 \\
\hline & 6 & $\therefore .413$ & 16167 & 1.120 & 717 & 0.033 & 327 & .124 & \\
\hline & 7 & 4.331 & 20178 & 1.677 & 11364 & 0.003 & 29 & 1.191 & 31371 \\
\hline 1 & 8 & 5.353 & 24835 & 2.314 & 15820 & 0.007 & 841 & .960 & 41499 \\
\hline & 9 & 6.476 & 2156 & 3.119 & 26 & 0.206 & 2765 & .553 & 51047 \\
\hline 1 & & 1.415 & 103942 & 1.775 & 60781 & 0.117 & 5760 & 1.593 & 170403 \\
\hline 2 & 0 & 7.699 & 35079 & 4.001 & 27118 & 0.059 & 379 & 3.001 & 63576 \\
\hline 2 & 1 & 9.017 & 11903 & 4.907 & & 1.016 & & .047 & 85648 \\
\hline & 2 & 10.429 & 48525 & 6.076 & & 1.519 & 15070 & .951 & .04717 \\
\hline 2 & 3 & 11,930 & 55162 & 7.264 & 20 & 2.193 & 21317 & 5.950 & 125099 \\
\hline 2 & 4 & 13.510 & 52719 & 8.550 & & 2.945 & 28570 & 7.065 & 140990 \\
\hline & & 10,516 & 244560 & 6.146 & 208035 & 1.551 & 75427 & 5.105 & 520030 \\
\hline & 5 & 15.109 & 70263 & 9.929 & 66010 & 3.003 & 36004 & 0.269 & 173079 \\
\hline & 6 & 16.939 & .78119 & 11.400 & 76471 & 1.769 & 45906 & 9.360 & 200576 \\
\hline & 7 & 18.764 & 85569 & 12.958 & & 5.836 & 53647 & 10.959 & 169 \\
\hline 2 & 8 & 20.660 & 1035 & 14.601 & 94609 & 7.003 & 19 & 12,439 & \\
\hline & 9 & 22.623 & 97347 & 16,324 & 102300 & 0.260 & 71511 & 14.004 & \\
\hline & 9 & 10.770 & 123335 & 12.906 & 426223 & 5.097 & 270209 & 10,997 & 1127067 \\
\hline & 10 & 24.640 & 102706 & & & 9.620 & & 15.651 & \\
\hline & 12 & 26.731 & 107324 & 19.996 & 75 & 11.000 & 93015 & 17.376 & \\
\hline 3 & 2 & 28.866 & & 21.936 & 74 & 12.620 & 101866 & 19.175 & \\
\hline & ] & 31.050 & 180 & 23.940 & & 14.245 & & & \\
\hline 3 & 4 & 33.277 & 317 & 26.003 & & 15.951 & 118704 & 22.979 & 107 \\
\hline J & 14 & 28.745 & 535169 & 21.043 & 04 & 12.581 & 500046 & 19.101 & \\
\hline & 15 & 35,541 & & 21 & & 17.735 & & 76 & \\
\hline 3 & 36 & 37.039 & 72 & 30.238 & 90 & 19.592 & & 29 & \\
\hline & 7 & 10.164 & & 32.501 & & 21. & & & \\
\hline & 8 & 42.511 & & 73 & & 23 , & & & \\
\hline J & 9 & 14.876 & 098 & 37.039 & 385 & 23.559 & & & \\
\hline $35 \cdot 3$ & 19 & 39.970 & 902 & 32.300 & 991 & 21.101 & & 74 & \\
\hline & 0 & 47.252 & 160 & 39.355 & es & 27.666 & & & \\
\hline & 1 & 49.634 & 128036 & 41.696 & 30 : & 29. & & & \\
\hline & 2 & 52.017 & 128165 & 11.053 & 187 & 32.026 & 1 & 0.273 & \\
\hline & ] & 34.396 & 699 & 16.120 & 81 & 31.270 & & 12.380 & \\
\hline & 1 & 56.765 & 128433 & 48.000 & 23 & 36. & & 20 & \\
\hline-8 & 1 & 31.800 & 640701 & 43.857 & 127 & 31.869 & 24101 & 0.090 & 225 \\
\hline & 5 & 59.118 & 28323 & 31.192 & 27 & 38.060 & & & \\
\hline & 6 & 01.450 & 11 & 53.573 & & 41.196 & & & 11 \\
\hline & 7 & 63.737 & & 55.245 & & 13.552 & & 63 & \\
\hline & 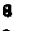 & 66.032 & 13 & 05 & & 45.922 & & & \\
\hline 4 & 9 & 69.271 & 129641 & 60.613 & & 01 & & & 35 \\
\hline . & 9 & 63.372 & 612294 & 95.773 & 819639 & 43.100 & 917006 & 01 & 237 \\
\hline & 0 & 70.460 & 0629 & 62.961 & 65 & 50.605 & & & \\
\hline 3 & 1 & 72.619 & 742 & 10 & & 67 & 3 & & \\
\hline 3 & 2 & & 1046 & 500 & 167 & 55.141 & & & \\
\hline & 3 & 7 & 0246 & 12 & & 37.004 & & & \\
\hline & 1 & 78.714 & 127116 & 9 & & 49 & & & \\
\hline 0 & & 74.523 & 651076 & 67.310 & 056409 & 55,270 & 6 & & \\
\hline & 3 & 80.661 & 121433 & 73.997 & & 62.170 & 504 & & \\
\hline & 6 & 02.508 & 141 & 76.060 & & 64 & & & \\
\hline 3 & 7 & 84.282 & 7907 & 78.064 & 150019 & & & & \\
\hline 5 & 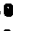 & 85.978 & 3942 & 80.005 & 256927 & 69 & 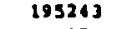 & & \\
\hline & 9 & 87.591 & 5 & & 28 & 22 & & & \\
\hline $55 \cdot 3$ & 9 & 01,059 & 3 & 36 & 17 & & & & 54 \\
\hline 6 & 0 & 0 & & & 08 & 51 & & & \\
\hline 6 & 1 & & & & & 26 & & & \\
\hline 6 & 2 & 17 & 861 & & & & & & \\
\hline & ] & & 603 & & 34 & 79.597 & & & \\
\hline 6 & 4 & 13 & 8 & & 123 & 11. & & & \\
\hline $80 \cdot 6$ & 4 & 1 & 328301 & 6.716 & & 17 & & 196 & 573 \\
\hline & 5 & 93.366 & 80913 & & 62 & 03. & & & \\
\hline 6 & & & 16 & & 34 & & & & \\
\hline 6 & 7 & & & & & 99 & & & \\
\hline 6 & 8 & & & & & & & & \\
\hline 6 & 9 & 98.528 & 8217 & & & 89.766 & 16 & & \\
\hline & & & 378098 & 93.851 & 31723 & 06.650 & & & \\
\hline & 0 & 9 & 64072 & & & & & & \\
\hline & 2 & 99.339 & 5 & & & 92.693 & & & \\
\hline 7 & & & 2351 & & 86840 & & & & \\
\hline & & & 5104 & & & & . & & \\
\hline 7 & 4 & 99.833 & 098 & & 70030 & 95.972 & & & \\
\hline & 4 & 99.469 & 92220 & 97.981 & 418691 & 93.634 & & & \\
\hline & & & 39047 & & & 96.757 & 190 & 269 & \\
\hline 7 & 6 & & 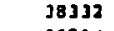 & & & & & 98,644 & 171972 \\
\hline 7 & 7 & .968 & 36714 & & & & & 30 & 165103 \\
\hline & & & 33541 & & 40690 & 98.102 & 69029 & & \\
\hline 7 & 9 & & & & & & & 230 & 133972 \\
\hline 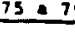 & & .954 & 9 & 99.621 & & 97.738 & & 98.820 & \\
\hline & & & 51708 & & 10200 & & 7077814 & & 0971730 \\
\hline
\end{tabular}


: 7.7. Edentulismo

A questão do edentulismo, ou ausência total de dentes em ambos os maxilares, merece um tópico a parte, sendo aqui enfocado a partir dos dados constantes da Tabela 32 e também das Tabelas $x$ e $X I$ do Anexo $V$, sendo que através desta última observa-se a exemplo das análises anteriores a precisāo do modelo estatístico $\left(R_{2}=0,96\right)$.

Os números e percentuais de pessoas edêntulas por idade e renda são provenientes dos exames bucais realizados em relação aos problemas periodontais. De acordo com o Indice Comunitário de Necessidades de Tratamento Periodontal, uma pessoa é considerada edêntula se em cada um dos sextantes bucais (o índice divide a boca em seis partes: dentes posteriores direito e esquerdo e baterial labial de cada maxilar) apresentar apenas um dente sadio ou não, ou vários dentes indicados para extração. Os 3os. molares não são incluidos no exame, a não ser que estejam em função no lugar dos 2os. molares $(87,172,173,180)$.

Há no Brasil, conforme as estimativas aqui desenvolvidas, 12,6 milhões de edêntulos, significando 17,78 da população urbana de 15 a 79 anos. Se estes números já se afiguram como extremamente severos, mais preocupante ainda é a situação dos grupos de idade mais avançada: a inexistência completa de dentes atinge a praticamente $40 \%$ entre 50 e 54 anos, a $77 \%$ entre 70 e 74 anos.

Para o conjunto da população estudada, o padrão médio de 108 de edentulismo é atingido aos 34 anos, acelerando-se a perda a partir dai, pois a marca dos 208 surge aos 41 anos, os 508 aos 58 anos e os 608 entre 62 e 63 anos.

Os estratos de alta renda apresentam as condiçōes mais favoráveis, mas à medida em que a idade aumenta, o "gap" em relação aos mais pobres se reduz. Assim, enquanto aos 27 anos de idade esta diferença é de cinco vezes, aos 38 anos é o dobro e aos 60 anos diminui para 1,3 vezes $(63,28 \times 48,28)$ segundo atabela 32 . Em geral, o grupo de 5 salários ou mais demora entre sete e oito anos para atingir o ponto ao qual já haviam chegado os que ganham de 0 a 2 salários.

Como seria de esperar a grande concentração de edêntulos ocorre na terceira idade, mas o volume de adultos mais jovens nesta condição é sem dúvida muito expressivo, estimando-se que $60,48(7,6$ milhões de pessoas) possui 50 anos ou mais, 38,38 (4,8 milhöes) está entre 25 e 49 anos com os restantes $1,38(171,4$ mil) entre 15 e 24 anos. Aos 30 anos na baixa renda já um de cada dez é edêntulo.

No Levantamento Epidemiológico, conforme os dados da amostra examinada, não foram encontradas diferenças significativas entre o diagnóstico do edentulismo pelos critérios do índice periodontal (CPITN) e do índice de prótese total. Neste último, o exame bucal informa os casos em que o paciente possui no máximo três dentes hígidos ou não por maxilar. 
Numa comparação a nível internacional, o Brasil leva nítida desvantagem pelo menos em relação a países mais desenvolvidos. 'Na população de 45 a 49 anos a média nacional é de 30\%, ou $24 \%$ no grupo de mais alta renda, ao passo que na Finlândia é de 11\%, na Dinamarca de 78 e na Noruega de 28 . Em torno de 158 dos norteamericanos de 50 a 59 anos são edêntulos, ao passo que no caso brasileiro é de $448(12,82,87,172,173,178,181)$ 
TABELA 32

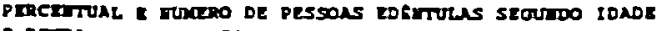

\begin{tabular}{|c|c|c|c|c|c|c|c|c|c|}
\hline \multirow{2}{*}{\multicolumn{2}{|c|}{ IDADE }} & \multicolumn{2}{|r|}{$0,25 . M 1$} & \multicolumn{2}{|r|}{ IS.H. } & \multicolumn{2}{|r|}{5 E. S.M. } & & TOTAL \\
\hline & & 1 & No. & 5 & No. & 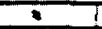 & No. & - & Mo. \\
\hline & 15 & 0.136 & 659 & 0.002 & 14 & 0.000 & 0 & 0.031 & 873 \\
\hline & 16 & 0.310 & 1311 & 0.056 & 186 & 0.000 & 0 & 0,080 & 1097 \\
\hline & 17 & 0.578 & 2693 & 0,197 & 1267 & 0,000 & 0 & 0.187 & 3960 \\
\hline & 18 & 0.213 & 4236 & 0.395 & 2666 & 0,000 & 0 & 0,327 & 6901 \\
\hline & 19 & 1.323 & 6181 & 0.679 & $1599^{\circ}$ & 0.001 & 10 & 0.309 & 10770 \\
\hline 15. & 19 & 0.618 & 15260 & 0.262 & 8932 & 0.000 & 10 & 0.226 & 24201 \\
\hline & 20 & 1,809 & 8430 & 1.038 & 7036 & 0.020 & 195 & 0.739 & 15661 \\
\hline & 21 & 2,368 & 12025 & 1.473 & 9976 & 0.000 & 78 & 0.996 & 21079 \\
\hline & 22 & 3.001 & 13963 & 1.983 & 13421 & 0.032 & 506 & 1.319 & 27890 \\
\hline & 23 & 3.706 & 17229 & 2.366 & 17352 & 0.200 & 1750 & 1.719 & 36330 \\
\hline & 24 & 1.412 & 20795 & 3.223 & 21791 & 0.303 & 3735 & 2.105 & 46281 \\
\hline $20 a$ & 24 & 3.072 & 71413 & 2.055 & 69535 & 0.129 & 6263 & 1.334 & 147241 \\
\hline & 25 & 5.328 & 24617 & 3.951 & 28585 & 0.663 & 6432 & 2.742 & 57665 \\
\hline & 26 & 6.212 & 28787 & 1.730 & 31863 & 1.022 & 9853 & 3.363 & 70505 \\
\hline & 27 & 7.224 & 32914 & 3.610 & 37265 & 1.454 & 13864 & 4.056 & 84073 \\
\hline & 28 & 8.272 & 36050 & 6,535 & 12474 & 1.960 & 10256 & 1.028 & 97500 \\
\hline & 29 & 9.383 & 10450 & 7.358 & 17402 & 2.512 & 22909 & 3.652 & 120769 \\
\hline 234 & 29 & 7.256 & 163685 & 5.635 & 185589 & 1,512 & 71316 & 3.405 & 120591 \\
\hline & 30 & 10.557 & 13990 & 8.627 & 32200 & 3.194 & 27820 & 6.552 & 124106 \\
\hline & 31 & 11.792 & 17344 & 9.739 & 36992 & 3.919 & 32900 & 7.320 & 137236 \\
\hline & 32 & 12,086 & 50517 & 10.953 & 61503 & 1.715 & 30050 & 0,553 & 150078 \\
\hline & $3 \mathbf{3}$ & 14.436 & S35s4 & 12.207 & 65069 & 3.501 & 13290 & 9.849 & 162714 \\
\hline & 34 & 25.042 & 56410 & 13.520 & 70039 & 6.515 & $\cos 16$ & 10.800 & 174973 \\
\hline $30 a$ & 34 & 13.039 & 251926 & 10.917 & 306690 & 1.720 & 190593 & 6.362 & 749207 \\
\hline & 33 & 17.298 & 58950 & 11.080 & 73809 & 7.515 & 33357 & 12.027 & 186324 \\
\hline & 36 & 18.006 & 61167 & 16,110 & 77161 & 8.581 & 98357 & 13.304 & 196605 \\
\hline & 37 & 20.361 & 63277 & 27.784 & 80263 & 9.711 & 83002 & 14.637 & 206142 \\
\hline & נe & 21.963 & 65083 & 19.308 & 93222 & 10.902 & 67548 & 16.025 & 215053 \\
\hline & 39 & 23.607 & 66060 & 20.070 & 96009 & 12.154 & 71973 & 17.165 & 224044 \\
\hline 35 & 39 & 20.261 & 315245 & 17.095 & 400464 & 9.665 & 314139 & 14,366 & 1030140 \\
\hline & 10 & 25.292 & 60309 & 22.494 & 98470 & 13.464 & 76122 & 18.956 & 23140 \\
\hline & 12 & 27.014 & 69606 & 24.152 & 90622 & 14.830 & 79909 & 20.194 & 240297 \\
\hline & 12 & 28.712 & 70881 & 25.049 & 92639 & 16.250 & B 3717 & 22.077 & 247247 \\
\hline & 43 & 30.563 & 72087 & 27.584 & $9463\}$ & 17.722 & 67399 & 23.703 & 251118 \\
\hline & 14 & 32.384 & 73270 & $29, \mathrm{J53}$ & 96599 & 19.213 & 91034 & 25.369 & 260902 \\
\hline 10 & 14 & 20.617 & 354323 & 23.733 & 462963 & 16.283 & 118531 & 21.901 & 1235817 \\
\hline & 45 & 34.321 & 74498 & 31.153 & 98358 & 20,212 & 94457 & 27.093 & 267313 \\
\hline & 16 & 36.103 & 73130 & 32.983 & 99662 & 22.426 & 97605 & 28.813 & 272617 \\
\hline & 17 & 37.796 & 75804 & 34.839 & 101634 & 24.082 & 100909 & 30.341 & 278127 \\
\hline & 10 & 39.900 & 77689 & 36.718 & 103970 & 25.778 & 104927 & 32.387 & 296506 \\
\hline & 19 & 11.035 & 79443 & 18.618 & 106660 & 27.511 & 109234 & 34.217 & 295345 \\
\hline 15. & 19 & 37.067 & 382504 & 34.737 & 310192 & 21,010 & 507221 & 30.491 & 1400287 \\
\hline & 30 & 43.775 & 81147 & 10.535 & 109297 & 29.278 & 113482 & 36.070 & 303928 \\
\hline & 31 & 15.724 & 82930 & 12.166 & 112038 & 31.078 & 117806 & 37.941 & 312093 \\
\hline & 52 & 17.680 & 04134 & 14.110 & 113904 & 32.906 & 121407 & 39.838 & 319325 \\
\hline & 33 & 19.610 & 84227 & 16.361 & 114119 & 34.761 & 123323 & 12.746 & 321968 \\
\hline & s4 & 31.600 & 83494 & 48,319 & 113724 & 36.639 & 123961 & 13.668 & 321178 \\
\hline 50. & 54 & 17.552 & 115952 & 14.287 & 563400 & 32.008 & 600050 & 39.723 & 1979491 \\
\hline & 33 & 33.557 & 82622 & 50.279 & 112022 & 30.330 & 124309 & 15,599 & 319752 \\
\hline & 36 & 35.509 & 81368 & 52.238 & 111379 & 10.435 & 123993 & 17,537 & 326740 \\
\hline & 37 & 37.453 & 80374 & 54.194 & 110277 & 42.386 & 123990 & 19.479 & 314635 \\
\hline & 38 & 39.193 & 80002 & 56.141 & 110124 & 14,328 & 124907 & 51.422 & 315193 \\
\hline & 59 & 61.303 & 80160 & 59.084 & 110474 & 16.200 & 126533 & 53,362 & 317168 \\
\hline 35 & 39 & 37.280 & 404605 & 51.025 & 555076 & 12.236 & 623000 & 19.319 & 1583488 \\
\hline & 60 & 63.203 & 80206 & 80.012 & 110084 & 18.237 & 128120 & 55.298 & 319291 \\
\hline & 12 & 65.083 & 81233 & 61.924 & 112204 & 30.197 & 010 & 125 & 324257 \\
\hline & 62 & 86.910 & 79871 & 03.818 & 110757 & 32.257 & 130122 & 41 & 320730 \\
\hline & 63 & 88.771 & 75004 & 65.691 & 104212 & 1.213 & 123401 & 043 & 302617 \\
\hline & 64 & 70.573 & 68017 & 67.510 & 94723 & 56.063 & 113027 & 32,828 & 275797 \\
\hline 60 & 64 & 86,669 & 284311 & 63.517 & 532059 & 51.093 & 625311 & 58.873 & 1542712 \\
\hline & 63 & 72.343 & 61379 & 69.162 & 85601 & 58.004 & 02 & 6.793 & 249802 \\
\hline & 68 & 71.080 & 53675 & 71.134 & 74908 & 59.032 & 20795 & 56.636 & 219459 \\
\hline & 67 & 73.779 & $\$ 1340$ & 72.913 & 71852 & 61.945 & 97600 & 60.152 & 210801 \\
\hline & 60 & 77.438 & 58023 & 71.630 & 82113 & 63.740 & 99860 & 0.241 & 239227 \\
\hline & 69 & 79.055 & 70702 & 76.324 & 99399 & 63.614 & 122035 & 71.998 & 293016 \\
\hline 65 & 60 & 75.787 & 295199 & 72.920 & 413105 & 61.003 & 504000 & 68.476 & 1212384 \\
\hline & 10 & 80.640 & 52190 & 77.974 & 73403 & 67.510 & 92397 & 1,761 & 216990 \\
\hline & 71 & 02.190 & 52203 & 79.580 & 73521 & 69.428 & 92201 & .0194 & 217928 \\
\hline & 12 & 83,701 & 50900 & 01.152 & 71782 & 12.261 & 90610 & 7.163 & 213294 \\
\hline & 73 & 85.177 & 47319 & 02.679 & 66910 & 73.030 & 84039 & 78.794 & 198969 \\
\hline & 74 & 86.581 & 12586 & 01.149 & 60194 & 71.750 & 76064 & 10.363 & 179641 \\
\hline 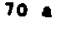 & 71 & 83.463 & 245199 & 80.902 & 315710 & 70.965 & 135916 & 76.895 & 1026821 \\
\hline & 73 & 07.068 & 34383 & 85.570 & 18640 & 76.425 & 82458 & 81.891 & 143689 \\
\hline & 76 & 09,291 & 31217 & 86.910 & 18502 & 78.098 & 62599 & 83,372 & 143347 \\
\hline & 77 & 90.560 & J3259 & 98.256 & 17146 & 79.610 & 61162 & 84,803 & 141367 \\
\hline & 78 & 91.771 & 30789 & 89.513 & 13683 & 81.107 & 56953 & 06.100 & 131426 \\
\hline & 70 & 92.922 & 27590 & 90.713 & 39189 & 82.672 & 51339 & 87.301 & 1818127 \\
\hline $15 \cdot$ & 79 & 0.337 & 160276 & 89.027 & 227169 & 79.390 & 294512 & 84.362 & 681956 \\
\hline Tण & & & 3459935 & & 302116 & & .592167 & & 12630248 \\
\hline
\end{tabular}




\section{: 7.8. Condições de Saúde Periodontal}

o Indice Comunitário de Necessidades de Tratamento Periodontal (ICNTP ou CPITN), em conformidade com as recomendações da organização Mundial de Saúde e da Federação Dentária Internacional $(87,172,180)$, foi utilizado no estudo brasileiro.

Neste sistema a dentição é dividida èm seis grupos (sextantes), ao invéz dos quatro mais comumente conhecidos. Em cada hemi-arcada há três sextantes: os dentes anteriores, de canino a canino, e dois posteriores que incluem pré-molares e molares. Cada sextante recebe um escore, representando a pior condição encontrada no exame epidemiológico: Os seis códigos adotados identificam a inexistência de doenças periodontais (0), a ausência de dentes (X), a presença de sangramento expontâneo (1), de cálculo (2), de bolsas periodontais superficiais (3) e de bolsas profundas (4).

Estimativas idade por idade e para a população de 15 a 79 anos de idade do percentual e do número de pessoas sem e com doenças periodontais compõem o Título 7.8 .1 a seguir.

Na publicação dos dados do Levantamento Epidemiológico em Saúde Bucal(34), os resultados relativos ao CPITN consideraram como base o número total de pessoas examinadas. Em seguida, a FDI e a OMS definiram para efeitos de comparaçāo internacional que a base deveria ser apenas as pessoas com dentes. Ou seja, o número de edêntulos consta mas não é tomado em consideração no indice $(12,57,87,172,173)$.

Isto tornou necessário o recálculo de todos os resultados do Levantamento brasileiro de maneiras a adapta-lo aos critérios internacionais. É o que se faz no Título 7.8 .2 ., mas restrito à amostra e aos grupos etários examinados em campo. Neste caso particular, ao contrário do conteúdo dos demais indicadores epidemiológicos ou de procura de atendimento até aqui analisados, não são feitas previsões estatísticas para o conjunto dos grupos etários, limitando-se portanto a apresentar as médias e percentuais originais para as idades de 15 a 19,35 a 44 e 50 a 59 anos.

\section{:: 7.8.1. População Sadia e Com Problemas Periodontais}

As Tabelas 33 e 34 no texto, e XII e XIII no Anexo V, detalham idade por idade, entre 5 e 79 anos, as proporções de residentes urbanos sadios ou não do ponto de vista periodontal. As variáveis dependentes idade e renda têm um poder de explicação mais limitadc do que nos indicadores anteriores, em relação à variável independente aqui considerada. 0 fator $R_{2}$ indica que 698 do problema é justificado através dos fatores incluidos no modelo de análise estatística. É provável que com o acréscimo por exemplo de dados sobre hábitos de higiene bucal e nível de educação, seja possível melhorar ainda mais a representatividade do modelo.

Desde os 15 anos, quando somente 308 da população urbana permanece sadia, a proporção de pessoas com problemas periodontais 
eleva-se continuamente ao longo da existência, chegando a 998 a partir dos 74 anos.

Convém repisar o critério de que estes números e proporçōes referem-se exclusivamente aos que conservam os seus dentes na boca, isto é, aos que não são edêntulos.

Se combinarmos os dados das tabelas 32 a 34 , teremos que para - total da população urbana de 15 a 79 anos (71,3 milhões), de cada cem pessoas aproximadamente 18 são edêntulas $(12,6$ milhōes), 16 são sadias $(11,2$ milhōes $) e$ as restantes $66(47,4$ milhões $)$ são portadoras de doenças periodontais.

As camadas de menor renda sāo mais sujeitas às doenças dos tecidos de suporte dentário do que as de média e alta renda. A diferença entre os dois primeiros estratos é pequena, mas há um salto quantitativo quando se compara a faixa de 5 e mais salários. Naturalmente, o inverso ocorre em relação à presença de doenças periodontais, quando os mais pobres é que detém os mais altos níveis de doença.

Considerando o universo de 47,4 milhões de brasileiros com problemas do periodonto, constatamos uma elevada concentração entre a população jovem. Nada menos que $1 / 3$ dos casos situa-se no grupo de 15 a 24 anos, ao passo que o grupo de adultos entre 25 e 49 anos responsabiliza-se por $55 \%$ do total, ficando os de 50 anos e mais com 128 de participação. Este fenômeno explica-se em parte porque 0 aumento relativo do percentual de pessoas afetadas é lento com a idade, sendo logo compensado pelo gradativo decréscimo da população. Porisso, temos que a maior expressão individual em termos de número de casos da-se aos 25 anos com 1.584 .030 pacientes em potencial, diminuindo idade por idade daí em diante até chegar à diminuta cota de 16.766 pessoas aos 79 anos. Já os sadios diminuem quantitativamente sempre: são 652.195 aos 6 anos e 108 aos 79 anos, numa evidente demonstração de que os esforços preventivos neste campo devem dar grande ênfase aos adolescentes e adultos jovens, tentando evitar a perda de condições mínimas de saúde periodontal.

\section{: 7.8.2. CPITN da Amostra Populacional}

Inicialmente, a Tabela 35 mostra uma estratificação do CPITN para os três estratos de renda e as três faixas etárias tomadas em consideração quando da realização dos exames bucais na amostra populacional estudada. As categorias utilizadas representam as camadas que no máximo apresentam sangramento gengival (ou seja, a pior situação diagnosticada em qualquer um dos sextantes refere-se ao código 1), cálculo, etc.

Desde logo, é possível notar que as diferenças entre os dados da amostra e os das projeções estatisticas apresentadas anteriormente quanto ao grupo sem doença periodontal são, como é lógico, pequenas.

Predomina, em todos os casos, o diagnóstico de presença de tártaro (cálculo), que afeta 428 no grupo de 15 a 19 anos; 478 de 
35 a 44 anos e 438 entre 50 e 59 anos. Os que têm sinais mais leves da enfermidade significam 208 do total na adolescência, mas perde: importância gradativamente $(12,5$ e 10,68$)$ cedendo o passo para 0 correspondente avanço dos casos mais graves, com bolsas superficiais ou profundas, que em conjunto passam de 88 do total para 28 e para 35,58. Confirma-se o observado na análise global feita no tópico 7.8.1., no sentido de que os problemas são maiores entre os mais pobres. Em relação aos que possuem bolsas periodontais profundas, por exemplo, entre 50 e 59 anos chegam à elevada proporção de 208 na baixa renda, embora não alcancem a 101 no extremo oposto da pirâmide salarial.

Uma medida adicional da maior ou menor gravidade das condiçōes periodontais é dada pela Tabela 36 , a qual fornece o número médio de sextantes afetados em cada uma das categorias definidas na tabela anterior.

Em média, um jóvem de 15 a 19 anos residente em uma cidaḋ brasileira possui 3,1 sextantes bucais hígidos; 2,7 com problemas periodontais e 0,2 excluidos por ausência de dentes. Dito de outra forma, ou seja, individualizando cada uma das categorias da Tabeia 36, cada adolescente apresenta aproximadamente 51,98 dos seus sextantes bucais livres de enfermidade periodontal, 2,68 edêntulos, 208 com sangramento, 23,28 com cálculo, 2,18 com bolsas superficiais e 0,28 com bolsas profundas. Essas proporçōes no grupo de 35-44 anos são respectivamente de $20,7-25,4-14-29,3-8,5$ - 2,18, e no de 50-59 anos: $11-41,2-9,9-23,8-9,4-4,78$.

Os dados sobre a média de sextantes são de maior validade para quem tem a seu cargo a implementação de programas de atendimento à comunidade, pois permite calcular os recursos humanos, materiais a financeiros necessários. Basta que cada serviço ou programa especifique seus critérios quanto ao tempo médio para realizar uma profilaxia p.ex. por sextante, para que possa estimar com razoáve! precisão o número de pessoas que poderá ser tratado num determinado período e a que custo (salários + insumos).

Os que recebem 5 ou mais salários têm em média mais sextantes sadios e menos sextantes edêntulos, com sangramento, cálculo o: bolsas, do que os demais.

Completando o conjunto de três tabelas que constituem o padrào para apresentação de resultados do CPITN, a de número 37 transforma os dados precedentes em necessidades de tratamento. Todos os que não estão livres de doenças periodontais devem receber instruções de higiene oral, ou seja, 698 entre 15 e 19 anos; $88 \%$ de 35 a 44 e 928 de 50 a 59 anos. A profilaxia está indicada para os que possuen depósitos cálcicos dentários (cálculo), 0 que abrange respectivamente 49,75 e 828 da população urbana. Quanto: tratamentos complexos, indicados para os com bolsas profundas, limita-se a $6 \%$ dos adultos entre 35 e 44 anos e a $14 \%$ entre 50 e 50 anos. A tabela fornece, também, o número médio de sextantes que requerem profilaxia e atenção complexa, resumindo, em última análise, o programa a desenvolver. Como exemplo de quantificação da população-alvo com base nesses índices. imaginemos una localidade 
com 20 mil habitantes de 35 a 44 anos, na qual devem existir 15 mil que necessitam profilaxia com um total de 34.500 sextantes a tratar (uma vez que $75 \%$ têm cálculos e bolsas, com a média por pessoa de 2,3). Se o tempo por profilaxia for de 10 minutos em cada sextante, para proporcionar cuidados adequados a 508 da população afetada, 0 serviço local de odontologia deverá ofertar em torno de 2875 horas - que significa colocar nesta tarefa aproximadamente duas equipes a tempo integral durante um ano.

Persistem as controvérsias entre os próprios periodontistas quanto ao comportamento fatalista ou não das doenças dos tecidos de suporte dental. Estudos epidemiológicos tem constatado que nem sempre há uma evolução natural de um estágio ao outro da doença. Por vezes condições mesmo aparentemente sérias estabilizam-se por vários anos ou chegam a regredir em função de outros condicionantes que não o tratamento odontológico, como práticas alimentares ou de higiene bucal adotadas pela comunidade(57,78.87). Em consequência, cada programa ou servico deve adotar seus próprios critérios, observando atentamente a evolução típica dos problemas periodontais na sua população-alvo, a fim de decidir quando e como intervir positivamente.

Ao aplicar o CPITN em operários da construção civil do Distrito Federal, o SESI encontrou(138), em relação ao levantamento nacional, uma situação um pouco melhor nos adolescentes e um pouco pior nos adultos. No grupo de 35 a 44 anos, p.ex., 48 dos trabalhadores estavam hígidos, 88 tinham só sangramento, 518 apresentavam cálculos, $26 \%$ bolsas superficiais e 108 bolsas profundas.

Em São Paulo, na faixa de 60 anos e mais(204), o quadro epidemiológico mostrou-se mais grave quanto à presença de bolsas profundas, localizadas em 678 dos examinados. Em compensação, 10,58 dos que tinham dentes permaneciam com o periodonto hígido, 58 tinham apenas gengivite e 178 cálculos.

Um trabalho realizado no Rio de Janeiro(86), sem especificar estratos de renda, levantou dados mais severos ao encontrar um menor número de sextantes hígidos e um maior com sangramento, cálculo e bolsas; mas a principal diferença para com o levantamento nacional está no inexpressivo número de "sextantes excluidos" (nenhum no grupo de $15-29 ; 0,3$ no de $35-44$ e 0,6 no de 45-54 anos) diagnosticado no estudo carioca, refletindo ou uma amostra muito diferenciada em relação ao padrão médio da cidade, ou critérios mais liberais para decidir quanto à funcionalidade ou não dos dentes examinados. Cabe assinalar ainda que o CPITN é um índice muito mais sujeito a discrepâncias intra e inter-examinadores do que o CPO, justificando desde logo uma maior dedicaça dos epidemiologistas brasileiros no sentido de consolidar mais os conhecimentos sobre o comportamento das doenças periodontais, principalmente pela comparação de resultados em distintos períodos de tempo para verificar a tendência dos processos mórbidos em populações típicas. 
Torna-se difícil estabelecer uma comparação consistente do quadro periodontal brasileiro emergente do estudo do Ministério da Saúde, com o de outros países. A OMS tem feito um grande esforço no sentido de obter dados nacionais com base no CPITN, mas persiste uma variação forte conforme 0 indicador escolhido. Se considerarmos, na população de 35 a 44 anos p.ex., a proporção dos que têm cálculos, o Brasil com 48 z aproxima-se bastante de paises distintos como a Itália, Japão, Portugal, Hungria, Hong Kong, Tailândia, Marrocos e Nepal. No entanto, se a comparação for feita pelos padrões de higidez, então nosso país com seus 128 ombreia-se entre outros com a Austrália, a Indonésia e o zimbabwe, ficando em posição sempre inferior quanto às oito naçōes antes citadas. Já nossos índices de bolsas profundas $(6,58)$ acompanham de perto os constatados na Finlândia, Hungria, Japão, Nova Zelândia, Portugal e Tanzânia $(172,173,178)$.

Seja por deficiências do índice, seja pelo conhecimento ainda limitado que 0 mundo atualmente possui sobre as enfermidades periodontais, o padrão geral de prevalência permanece indefinido. Não obstante, parece claro que a situação epidemiológica brasileira neste campo não é tăo desvantajosa como a mostrada para a cárie dental.

Em geral, os países industrializados que conseguiram controlar a incidência da cárie dedicam grande parte de seus esforços e recursos de pesquisa para a área periodontal, procurando paralelamente estabelecer metas de sua redução em termos de saúde pública. No caso brasileiro, os altos índices de cárie pressionam os serviços odontológicos de tal forma que pouco espaço resta para políticas voltadas para a prestação de cuidados periodontais a nível comunitário, limitando-se a profissão fundamentalmente a aconselhar a prática correta da escovação a seus pacientes. 
TAsech 33

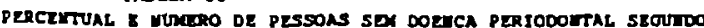

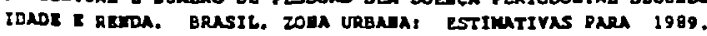

\begin{tabular}{|c|c|c|c|c|c|c|c|c|}
\hline \multirow[t]{2}{*}{ IOADE } & \multirow{2}{*}{\multicolumn{2}{|c|}{$\frac{A 2 \text { S.M. }}{40 .}$}} & \multicolumn{2}{|c|}{$3: S, M$} & \multirow{2}{*}{\multicolumn{2}{|c|}{$5 E \cdot 5.4$}} & & TOTAL \\
\hline & & & SIDP & Ho. & SIDP & & S/DP & Bo. \\
\hline 15 & 36.011 & 125940 & 27.321 & 192669 & 32.906 & 333386 & 29.603 & 652195 \\
\hline 16 & 25.299 & 119159 & 26,598 & 183163 & 32,143 & 318365 & 28,866 & 620987 \\
\hline 17 & 24.394 & 113919 & 25, 801 & 175057 & 31.384 & 305723 & 28.133 & 594700 \\
\hline 18 & 23.096 & 109091 & 25.171 & 169188 & 30,630 & 297128 & 27.412 & 576266 \\
\hline 19 & 23.204 & 106623 & 24.667 & 164597 & 29.882 & 290946 & 26.895 & 562165 \\
\hline $5 \cdot 19$ & 21.619 & 375792 & 25.905 & 884674 & 31.104 & 1545748 & 28.159 & 3006214 \\
\hline 20 & 22.520 & 103049 & 23.770 & 159452 & 29.139 & 283874 & 25.986 & 516374 \\
\hline 21 & 21.813 & 99293 & 23.080 & 154003 & 28.102 & 276169 & 25.284 & 529765 \\
\hline 22 & 21.274 & 95364 & 22,397 & 169574 & 27.669 & 269046 & 24.389 & 513183 \\
\hline 23 & 20.512 & 91023 & 21.721 & 143110 & 26.943 & 261420 & 23.900 & 196363 \\
\hline 24 & 19.050 & 880003 & 21.053 & 137500 & 26.224 & 253123 & 23.219 & 178978 \\
\hline 0.24 & 21.192 & 177736 & 22.413 & 762639 & 27.878 & 1341240 & 24.602 & 2561613 \\
\hline 23 & 19.212 & 04140 & 20.393 & 131790 & 25.310 & 263107 & 22.364 & 461046 \\
\hline 26 & 18.574 & 80312 & 19.740 & 126127 & 24.003 & 236726 & 21.877 & 413164 \\
\hline 27 & 17.944 & 75910 & 19,096 & 119551 & 21.103 & 226104 & 21.217 & 121953 \\
\hline 28 & 17,323 & 70786 & 18.459 & 112767 & 23.409 & 213769 & 20.364 & 396322 \\
\hline 29 & 16.711 & 65294 & 17.032 & 103305 & 22.723 & 199637 & 19.919 & 368337 \\
\hline-28 & 17,980 & 376451 & 19.138 & 592628 & 24.140 & 1121743 & 21.257 & 2090022 \\
\hline jo & 16.108 & 60035 & 17,212 & 95321 & 22.044 & 185927 & 19.282 & 341283 \\
\hline 31 & 15,513 & 54939 & 16.001 & 87487 & 21.372 & 172384 & 10.653 & J16811 \\
\hline 32 & 14.928 & 50007 & 16.000 & 80002 & 20.700 & 159269 & 18.032 & 289358 \\
\hline 33 & 16,352 & 43596 & 15.407 & 72988 & 20.051 & 116031 & 17.120 & 263395 \\
\hline 34 & 13.785 & 11318 & 14,823 & 66407 & 19.103 & 135077 & 16.016 & 242803 \\
\hline - 34 & 19,000 & 251936 & 16.072 & 102206 & 20.779 & 799500 & 18.103 & 1453649 \\
\hline 35 & 13.299 & 37407 & 16.249 & 60124 & 18.763 & 123660 & 16.235 & 221280 \\
\hline 36 & 12.681 & 33409 & 13.684 & 54179 & 18,131 & 112123 & 15.634 & 200391 \\
\hline 37 & 12,114 & 30000 & 13.129 & 40716 & 17,507 & 102551 & 15.057 & 101273 \\
\hline 30 & 11.617 & 26064 & 12.584 & 13767 & 16,097 & 93252 & 14.189 & 163003 \\
\hline 39 & 11.100 & 24016 & 12.040 & 39270 & 16.286 & 84723 & 13.930 & 248008 \\
\hline 39 & 12.210 & 151005 & 13.210 & 246037 & 17.589 & 516916 & 15.141 & 914838 \\
\hline 10 & 10.393 & 21399 & 11.923 & 35126 & 15.689 & 76759 & 11.052 & 133203 \\
\hline 11 & 10.097 & 19010 & 11.000 & 31328 & 15.101 & 69372 & 12.842 & 119710 \\
\hline 12 & 9.611 & 16867 & 10.303 & 27911 & 14.322 & 62657 & 12.312 & 107435 \\
\hline a & 9.137 & 11964 & 10,009 & 24066 & $\{3.933$ & 56617 & 11.791 & 96447 \\
\hline 14 & 8.673 & 13268 & 9.525 & 22145 & 13.393 & 51167 & 11.281 & 96580 \\
\hline 14 & 9,689 & as50B & 10,381 & 141377 & 14.604 & 316370 & 12.390 & 543456 \\
\hline 15 & 18.219 & 25914 & 9.052 & 19676 & 12.843 & 16138 & 12,163 & 91808 \\
\hline 16 & 7.778 & 10345 & 0.590 & 17430 & 12.303 & $\$ 1538$ & 10.291 & 69313 \\
\hline 17 & 7.347 & 9166 & 9.1.J9 & 15171 & $11.77 \mathrm{~J}$ & 37181 & 9,810 & 62118 \\
\hline 18 & 6.927 & $810 \mathrm{~J}$ & 7.699 & 13796 & 11.253 & 33997 & 9,343 & 59896 \\
\hline 49 & 6.519 & 7200 & 7.270 & 12326 & 10.743 & 30971 & 8.804 & 50447 \\
\hline 19 & 9.683 & 60788 & 8.206 & 78699 & 11.811 & 190094 & 10,325 & 329582 \\
\hline 30 & 8.123 & 6382 & 8.053 & 10900 & 10.214 & 28001 & 8.437 & 45451 \\
\hline 31 & 3.730 & 5630 & 6.147 & 9781 & 9.735 & 25303 & 1.001 & 10941 \\
\hline 32 & 5.365 & 4953 & 6.052 & 9635 & 9.277 & 22965 & .575 & 36553 \\
\hline 33 & 3.004 & 1276 & 5.670 & 7506 & 8,200 & 20389 & 7.160 & 32170 \\
\hline 94 & 1.654 & 3643 & 3.299 & 6446 & 8,353 & 17906 & 6.757 & 27997 \\
\hline 94 & 3.429 & 24905 & 6.117 & 43362 & 9.345 & 114863 & 7.641 & 183111 \\
\hline 55 & 1.J17 & 3093 & 1.940 & 5312. & 1,908 & 15678 & 6.365 & 21282 \\
\hline 56 & 3.992 & 2603 & 4.593 & 1677 & 7,174 & 13640 & 5.915 & 20921 \\
\hline 57 & 3.679 & 2190 & 4.258 & 3969 & 7.051 & 11803 & 5.616 & 10041 \\
\hline 50 & 3.379 & 1051 & 3.935 & 3385 & 6.639 & 10121 & 5.230 & 15657 \\
\hline 59 & 3.090 & 1584 & 3.324 & 2808 & 0.260 & 9145 & 4,084 & 13538 \\
\hline $55 \cdot 59$ & 9.407 & 11301 & 1, Jo9 & 20352 & 7.125 & 607197 & 3.681 & 92440 \\
\hline 60 & 2.825 & 1316 & 3.326 & 2437 & 3.851 & 0014 & 6.578 & 11828 \\
\hline 61 & 2.351 & 1110 & 3.010 & 2098 & 3.173 & 7107 & 1.236 & 10317 \\
\hline 62 & 2.301 & 908 & 2.766 & 1737 & 3.110 & 6099 & 3.916 & 8744 \\
\hline 63 & 2.063 & 703 & .505 & 1363 & 4.737 & 1970 & 3.847 & 7044 \\
\hline 64 & 1.830 & 322 & 2.257 & 1027 & 1.116 & 2912 & 3.362 & 5461 \\
\hline 0.64 & 2.372 & 1558 & 2.841 & 8604 & 5.198 & 30140 & 4.025 & 43392 \\
\hline 65 & 1.625 & 381 & 2.022 & 764 & 4.080 & 3046 & 3,087 & 1191 \\
\hline 66 & 1.126 & 268 & 1.798 & 517 & 3.771 & 2289 & 2.824 & 3103 \\
\hline 67 & 1.239 & 203 & 1,580 & 124 & 3.167 & 1874 & 2.374 & 2501 \\
\hline 60 & 1.065 & 180 & 1.391 & 394 & 3.175 & 1804 & 2.337 & 2368 \\
\hline 69 & 0.904 & 170 & 1.207 & 312 & 2.895 & 1864 & 2,111 & 2405 \\
\hline 169 & 1.274 & 1202 & 1.624 & 2491 & 3.503 & 10876 & 2.610 & 14569 \\
\hline 70 & 0.760 & 96 & 1.047 & 217 & 2.606 & 1114 & 1.089 & 1458 \\
\hline 71 & 0.647 & 73 & 0,902 & 170 & .345 & 952 & 1.609 & 1195 \\
\hline 72 & 0,541 & 34 & .732 & 122 & .111 & 711 & 1.500 & 947 \\
\hline 73 & 0.419 & 37 & .659 & 92 & 1.900 & 595 & 1.353 & 724 \\
\hline 34 & 0.366 & 24 & 0.337 & 83 & 1.710 & 114 & 1,210 & 531 \\
\hline $70=74$ & 0.585 & 284 & 0.814 & 665 & 2.191 & 3907 & 1.574 & 1856 \\
\hline 13 & 0.296 & 14 & .1680 & 38 & 1.505 & 290 & 1.064 & 342 \\
\hline 76 & 0.230 & 10 & 0.391 & 28 & 1.324 & 233 & 0.936 & 271 \\
\hline 77 & 0.189 & 7 & 0.324 & 20 & 1,165 & 182 & 0.824 & 209 \\
\hline 78 & 0.150 & 4 & 0.268 & 14 & 1.025 & 135 & 0.727 & 153 \\
\hline 19 & 0.119 & 3 & 0.219 & 9 & 0.902 & 97 & 0.642 & 108 \\
\hline $75 \cdot 19$ & 0.215 & 37 & 0,355 & 110 & 1.226 & 937 & 0.871 & 1084 \\
\hline TOTAL & & 2022362 & & 63943 & & 056312 & & 1242617 \\
\hline
\end{tabular}




\begin{tabular}{|c|c|c|c|c|c|c|c|c|}
\hline \multirow[t]{2}{*}{ IDADE } & \multicolumn{2}{|c|}{$0 \wedge 25.4}$. & \multicolumn{3}{|c|}{ BEIS.M } & \multicolumn{2}{|c|}{$5 \mathrm{E} \cdot 5 . \mathrm{M} / \mathrm{TOTAL}$} & H. \\
\hline & C/DP & s: & C/DP & $\mathrm{N}^{\circ}$ & $-C / D P$ & & & \\
\hline 15 & 73.909 & 358210 & 72.679 & 512537 & 67.094 & 000168 & 70.398 & 1550919 \\
\hline 16 & 74.701 & 352731 & 73,402 & 505471 & 67.857 & 672101 & 71.137 & 1530302 \\
\hline 17 & 75,406 & 349280 & 71,119 & 502336 & 68.616 & 668415 & 71.871 & 1519031 \\
\hline 18 & 76.204 & 349853 & 74,829 & 502966 & 69,370 & 672926 & 72.598 & 1525744 \\
\hline 19 & 76.796 & 352879 & 75.533 & 500132 & 70.218 & 682703 & 73,320 & 1543716 \\
\hline $15 \cdot 19$ & 75.381 & 1762982 & 74.095 & 2530414 & 68,596 & 3376313 & 72.039 & 7669740 \\
\hline 20. & 77.480 & 354539 & 76.230 & 511357 & 70,061 & 690332 & 74.035 & 1536227 \\
\hline 21 & 78.157 & 355281 & 76,920 & $\$ 13256$ & 71.599 & 696978 & 74,74 & 1565515 \\
\hline 22 & 70.026 & 355764 & 77.603 & 324792 & 72.331 & 703329 & 73.447 & 1573884 \\
\hline 23 & 79.480 & 355840 & 78.279 & 315747 & 73.057 & 708972 & 76.143 & 1590459 \\
\hline 24 & 80.142 & 355160 & 78,047 & 315612 & 73.776 & 712956 & 76.031 & 1583735 \\
\hline 20.24 & 78.808 & 1776590 & 77.587 & 2570764 & 72.322 & j51246e & 73.808 & 7859822 \\
\hline 25 & $B 0.788$ & 353815 & 79.607 & 514493 & 74.490 & 715721 & 77.513 & 1584030 \\
\hline 26 & 81.126 & 352077 & 60,260 & 512812 & 75,197 & 717690 & 78,188 & 1582587 \\
\hline 27 & 82.056 & 347167 & 00.004 & $30 \leqslant 500$ & 75.097 & 713168 & 70.854 & 1566835 \\
\hline 28 & 82.677 & 337038 & 81.541 & 493721 & 76.591 & 699421 & 79.514 & 1530981 \\
\hline 29 & 03.289 & 325432 & 02.168 & 476389 & 77.277 & 679000 & 00.163 & 1480820 \\
\hline $25 \cdot 29$ & 82.012 & 2716331 & 80,062 & 2503916 & 75.060 & 3525007 & 78,908 & 7745253 \\
\hline 30 & 03.892 & 312666 & 82.788 & 450497 & 77.956 & 657509 & 80.908 & 1428661 \\
\hline $\mathbf{3 1}$ & 04.487 & 299211 & 03.390 & 439513 & 78.628 & 631205 & 91.641 & 1372939 \\
\hline 32 & 85.072 & 285437 & 84.000 & 120010 & 79.292 & 609850 & 02.070 & 1313296 \\
\hline 33 & 85.648 & 271865 & 84.593 & 400744 & 79.949 & 583535 & 02.609 & 1258144 \\
\hline 34 & 86.213 & 258416 & 85.177 & 381594 & 80.597 & 562009 & 03.299 & 1201098 \\
\hline $30 \cdot 34$ & es, 000 & 1427595 & 83.928 & 2100347 & 79.221 & 3048197 & 02.572 & 6576128 \\
\hline 35 & 06,701 & 244393 & 05.751 & 361831 & 01.237 & 535438 & 03.804 & 1141663 \\
\hline 36 & 87. 319 & 230596 & 06.316 & 341752 & 01.869 & 508990 & 04.491 & 1081339 \\
\hline 37 & 87.056 & 217097 & 06.071 & 322341 & 82,493 & 403219 & 85.074 & 1022657 \\
\hline 38 & 88,383 & 204382 & 07.416 & 300034 & 03.108 & 158796 & 85.647 & 967212 \\
\hline 39 & 08.900 & 192345 & 87.952 & 286600 & 03.714 & 435494 & 06.211 & 914319 \\
\hline $35 \cdot 39$ & 87.760 & 1088014 & 06.790 & 1616630 & 92.412 & 2421938 & 05.842 & 5127390 \\
\hline 10 & 89.407 & 180609 & 88.477 & 269708 & 04.311 & $41249\}$ & 06.765 & 1072650 \\
\hline 11 & 89.903 & 169265 & 08.992 & 253266 & 04.099 & 390012 & 87. 310 & 812543 \\
\hline 12 & 90.389 & 158631 & 09.497 & 237035 & 85.478 & 360005 & 87,845 & 765272 \\
\hline 43 & 90.863 & 148011 & 09.991 & 223572 & 86.047 & 319150 & 88,369 & 721533 \\
\hline 14 & 91.327 & 139715 & 90.475 & 210351 & 86,607 & 330874 & 88,883 & 600938 \\
\hline 10.44 & 90.311 & 797030 & 89.419 & 1194731 & 85.396 & 1851063 & 90.992 & 3842823 \\
\hline 15 & 01.781 & 116590 & 90.948 & 197692 & 87.257 & 313243 & 07.187 & 627326 \\
\hline 16 & 92.222 & 122659 & 91.110 & 185477 & 97.697 & 296088 & 89.881 & 604224 \\
\hline 47 & 92.653 & 115591 & 91.061 & 174619 & 88.227 & 280884 & 90,364 & 571094 \\
\hline 18 & 93.073 & 108878 & 92.301 & 165392 & 88.747 & 268116 & 90.836 & 542367 \\
\hline 19 & 93.181 & 103253 & 92.730 & 257219 & 89.257 & 256901 & 91.298 & 517372 \\
\hline 15.49 & 90.317 & 566972 & 91.794 & 080400 & 00.159 & 1415231 & 90.584 & 2862603 \\
\hline 50 & 93.877 & 97845 & 93.117 & 149350 & 89.756 & 246038 & 91.748 & 493234 \\
\hline 31 & 94,262 & 92015 & 93.553 & 142031 & 90,245 & 235933 & 92.187 & 170778 \\
\hline 32 & 94.635 & 87368 & 93.948 & 134044 & 90.723 & 224580 & 92.616 & 115992 \\
\hline 53 & 94.996 & 01172 & 94.330 & 224075 & 91.191 & 211062 & 93.033 & 417110 \\
\hline 34 & 95.346 & 71671 & 94.701 & 115101 & 91.647 & 196463 & 93.438 & 386326 \\
\hline 50.51 & 94.571 & 133672 & 93.883 & 665491 & 90.655 & 1114076 & 92.921 & 2213439 \\
\hline ss & 95.683 & 60554 & 95.060 & $10 \cos \theta$ & 92.092 & 182579 & 93,032 & 357107 \\
\hline 36 & 96,008 & 62624 & 95.407 & 97158 & 92,526 & 169063 & 94.214 & 328835 \\
\hline 57 & 96,321 & 57332 & 95.742 & 89240 & 92.949 & 156644 & 94.585 & 303226 \\
\hline 58 & 96.621 & 52919 & 96.065 & 82637 & 93.361 & 146551 & 94.943 & 292107 \\
\hline 59 & 96.910 & 19037 & 96.476 & 76914 & 93.760 & 137720 & 93.322 & 263660 \\
\hline 55.59 & 94.593 & 290455 & 95.691 & 452007 & 92.075 & 792344 & 94.790 & 1534806 \\
\hline 60 & $97+285$ & 45127 & 96.674 & 71420 & 94.149 & 129441 & 95.625 & 216397 \\
\hline 61 & 97,449 & 12417 & 96.960 & 66942 & 94.525 & 122706 & 95.947 & 232086 \\
\hline 62 & 97.699 & 38539 & 97.234 & 61050 & 91,890 & 113260 & 96.258 & 212056 \\
\hline 63 & 97.937 & 33357 & 97.495 & 53064 & 95.243 & 99664 & 96.556 & 186005 \\
\hline 84 & 98.162 & 27852 & 97.743 & 14197 & 95.584 & 84668 & 96.842 & 157017 \\
\hline 60.64 & 97.628 & 187592 & 97.159 & 296989 & 94,802 & 549741 & 96,381 & 1034323 \\
\hline 65 & 98,375 & 23084 & 97.979 & 37047 & 95.912 & 71457 & 97.115 & 132588 \\
\hline 66 & 90.574 & 18513 & 98,202 & 29054 & 96.229 & 58423 & 97,376 & 106780 \\
\hline 67 & 90.761 & 16206 & 98.412 & 26269 & 96.533 & 52176 & 97.621 & 94651 \\
\hline 68 & 98,935 & 16725 & 98.609 & 27257 & 96,825 & 55004 & 97,860 & 98905 \\
\hline 69 & 99.096 & 28584 & 98.793 & 30462 & 97.105 & 62510 & 98.083 & 111555 \\
\hline 65.69 & 98.726 & 93112 & 98.376 & 150888 & 96.197 & 299360 & 97.741 & 513559 \\
\hline 70 & 99.232 & 12434 & 98.953 & 20318 & 97,394 & 12781 & 98,297 & 75733 \\
\hline 71 & 99.353 & 11239 & 99.098 & 18695 & 97.655 & 39649 & 98.490 & 69583 \\
\hline 72 & 99,459 & 9858 & 99.268 & 16550 & 97.889 & 35771 & 98.678 & 62179 \\
\hline 73 & 99.551 & 8198 & 99.341 & 13904 & 98.100 & 30723 & 98.016 & 32825 \\
\hline 74 & 99.634 & 6569 & 99.113 & 11276 & 90.290 & 25320 & 98.055 & 43364 \\
\hline 70.74 & 99.415 & 48297 & 99.186 & 90942 & 97.009 & 174645 & 98.687 & 303689 \\
\hline 75 & 99.704 & 1689 & 99.332 & 0265 & 98.493 & 18977 & 99,093 & 31831 \\
\hline 76 & 99.762 & 1098 & 99.609 & 7257 & 98.676 & 17363 & 99.213 & 28727 \\
\hline 77 & 99,811 & 3460 & 99.676 & 6253 & 98.835 & 15446 & 99.319 & 25160 \\
\hline 70 & 99.850 & 2757 & 99.732 & 5203 & 98.975 & 13062 & 99.410 & 20922 \\
\hline 79 & 99.881 & 2100 & 99.781 & 1002 & 99.090 & 10564 & 99.489 & 16766 \\
\hline 75.79 & 99.785 & 17108 & 99.645 & 30788 & 98.774 & 75521 & 99.129 & 123116 \\
\hline TOTAL & & 10206749 & & 15074344 & & 22155893 & & 47436907 \\
\hline
\end{tabular}


TABELA 35

PERCENTUAL DE PESSOAS SEGUNDO O ESCORE MAIS

ALTO DO CPITN EM GRUPOS DE RENDA E DE IDADE

SELECIONADOS. BRASIL, ZONA URBANA.

\begin{tabular}{l|c|r|r|r|r|r}
\hline $\begin{array}{l}\text { RENDA } \\
\text { FAMILIAR }\end{array}$ & IDADE & $\begin{array}{c}\text { SEM DOENCAA } \\
\text { PERIODONTAL } \\
(0)\end{array}$ & $\begin{array}{c}\text { SOMENTE } \\
\text { SANGRAMENTO } \\
(1)\end{array}$ & $\begin{array}{c}\text { CÁCCULO } \\
\text { (2) }\end{array}$ & $\begin{array}{c}\text { BOLSAS } \\
\text { SUPERFICIAIS } \\
(3)\end{array}$ & $\begin{array}{c}\text { BOLSAS } \\
\text { PROFUNDAS } \\
(4)\end{array}$ \\
\hline ATE 2 & $15-19$ & 23,335 & 15,868 & 48,413 & 11,325 & 1,057 \\
SALARIOS & $35-44$ & 9,331 & 11.230 & 47,481 & 24,525 & 7,431 \\
& $50-59$ & 6,196 & 7.692 & 37.820 & 28,418 & 19,871 \\
3E4 & $15-19$ & 32,505 & 20,379 & 39,444 & 6,939 & 0.730 \\
SALÁRIOS & $35-44$ & 10,441 & 13,119 & 49,799 & 20,348 & 6,291 \\
& $50-59$ & 6.562 & 11,562 & 47.500 & 20,937 & 13,437 \\
5E & $15-19$ & 34.700 & 23.170 & 38,525 & 3.215 & 0,388 \\
SALÁRIOS & $35-44$ & 16,485 & 14,168 & 46,185 & 18,119 & 5.040 \\
& $50-59$ & 8,695 & 13,623 & 45,217 & 22,898 & 9,565 \\
& $15-19$ & 30,251 & 19,916 & 42,112 & 7,008 & 0,711 \\
TOTAL & $35-44$ & 11,589 & 12,555 & 47,771 & 21,619 & 6,463 \\
& $50-59$ & 7.060 & 10,591 & 42,806 & 24,624 & 14,916 \\
\hline
\end{tabular}

Fontes: Bibliogratias 34,172. 
TABELA 36

NÚMERO MEDIO DE SEXTANTES BUCAIS SADIOS.

COM DOENÇA PERIODONTAL E EDENTULOS SEGUNDO

O CPITN EM GRUPOS SELECIONADOS DE RENDA E

IDADE. BRASIL, ZONA URBANA.

\begin{tabular}{|c|c|c|c|c|c|c|c|}
\hline $\begin{array}{l}\text { RENDA } \\
\text { FAMILIAR }\end{array}$ & IDADE & $\begin{array}{c}\text { SEM DOENCA } \\
\text { PERIODONTAL } \\
(0)\end{array}$ & $\begin{array}{c}\text { SANGRAMENTO } \\
\text { OU ESCORE + } \\
\text { ALTO } \\
(1+2+3+4) \\
\end{array}$ & $\begin{array}{l}\text { CÁLCULO } \\
\text { OU ESCORE } \\
+ \text { ALTO } \\
(2+3+4) \\
\end{array}$ & $\begin{array}{c}\text { BOLSAS SUPERF, } \\
\text { OU ESCORE } \\
\text { MAIS ALTO } \\
(3+4)\end{array}$ & $\begin{array}{c}\text { BOLSAS } \\
\text { PROFUNDAS } \\
\text { (4) }\end{array}$ & \begin{tabular}{|c|} 
EXCLUIDWS \\
MENOS $Q$ \\
2 DENTES \\
$(X)$
\end{tabular} \\
\hline ATE 2 & $15-19$ & 2,616 & 3,101 & 1,962 & 0,231 & 0.016 & $0,204$. \\
\hline \multirow[t]{2}{*}{ SALARAOS } & $35-44$ & 0.914 & 3,309 & 2,612 & 0.776 & 0,161 & $t, \pi \mid$ \\
\hline & $50-59$ & 0,519 & 2,801 & 2,399 & 1,049 & 0,356 & 2,679 \\
\hline $3 E 4$ & $15-19$ & 3.277 & 2,589 & 1,477 & 0.141 & 0,013 & 0,132 \\
\hline \multirow[t]{2}{*}{ SALÁAIOS } & $35-44$ & 1.250 & 3,182 & 2,314 & 0,548 & 0,116 & $1,50^{\circ}$ \\
\hline & $50-59$ & 0,615 & 2.800 & 2,196 & 0,762 & 0,265 & 2,584 \\
\hline $5 E+$ & $15-19$ & 3,431 & 2.506 & 1.190 & 0.059 & 0,007 & 0,06 \\
\hline \multirow[t]{3}{*}{ SALÁRIOS } & $35-44$ & 1,764 & 3.170 & 2,118 & 0.469 & 0,084 & $1,0 \mathrm{~s}$; \\
\hline & $50-59$ & 0.901 & 3,002 & 2,162 & 0,628 & 0.188 & 2,008 \\
\hline & $15-19$ & 3,113 & 2.730 & 1,532 & 0,141 & 0.012 & 0,15 \\
\hline \multirow[t]{2}{*}{ TOTAL } & $35-44$ & 1,239 & 3,236 & 2,395 & 0.634 & 0,127 & 1,58 \\
\hline & $50-59$ & 0,662 & 2,862 & 2.270 & 0.840 & 0,279 & 2,47 \\
\hline
\end{tabular}

Fontes: Bibliogratias 34,172 . 
TABELA 37

NECESSIDADES DE TRATAMENTO PERIODONTAL

SEGUNDO O CPITN EM GRUPOS DE RENDA E

IDADE SELECIONADOS. BRASIL, ZONA URBANA.

\begin{tabular}{|c|c|c|c|c|}
\hline $\begin{array}{l}\text { RENDA } \\
\text { FAMILIAR }\end{array}$ & IDADE & $\begin{array}{c}\text { INSTRUCAO EM } \\
\text { HIGIENE ORAL } \\
(\%)\end{array}$ & $\begin{array}{l}\text { PROFILAXIA* } \\
\text { (\%) (NMS) }\end{array}$ & $\begin{array}{l}\text { TAATAMENTO } \\
\text { COMPLEXO } \\
(\%) \text { (NMS) }\end{array}$ \\
\hline $\begin{array}{l}\text { ATE } 2 \\
\text { SALARIOS }\end{array}$ & $\begin{array}{l}15-19 \\
35-44 \\
50-59\end{array}$ & $\begin{array}{l}77 \\
91 \\
94\end{array}$ & $\begin{array}{ll}61 & (1.96) \\
79 & (2.61) \\
86 & (2.40)\end{array}$ & $\begin{array}{rr}1 & (0.01) \\
7 & (0.16) \\
20 & (0.39)\end{array}$ \\
\hline $\begin{array}{l}3 \text { E } 4 \\
\text { SALARIOS }\end{array}$ & $\begin{array}{l}15-19 \\
35-44 \\
50-59\end{array}$ & $\begin{array}{l}67 \\
90 \\
93\end{array}$ & $\begin{array}{l}47(1.48) \\
76(2.31) \\
82(2.20)\end{array}$ & $\begin{array}{r}1(0.01) \\
6(0.12) \\
13(0.26)\end{array}$ \\
\hline $\begin{array}{l}5 E+ \\
\text { SALARIOS }\end{array}$ & $\begin{array}{l}15-19 \\
35-44 \\
50-59\end{array}$ & $\begin{array}{l}65 \\
83 \\
91\end{array}$ & $\begin{array}{l}42(1.19) \\
69(2.12) \\
78(2.16)\end{array}$ & $\begin{array}{c}0(0.00) \\
5(0.01) \\
10(0.19\end{array}$ \\
\hline TOTAL & $\begin{array}{l}15-19 \\
35-44 \\
50-59\end{array}$ & $\begin{array}{l}70 \\
88 \\
93\end{array}$ & $\begin{array}{ll}50 & (1.53) \\
76 & (2.39) \\
82 & (2.27)\end{array}$ & $\begin{array}{rr}0 & (0.01) \\
6 & (0.13) \\
15 & (0.28)\end{array}$ \\
\hline
\end{tabular}

Fontes: Bibllografias 34,172. 


\section{PROGRAMAS E POLÍTICAS DE SAÚdE BUCAL}

o modelo liberal de prática odontológica não alcançou o êxito esperado no caso brasileiro, se considerarmos os seus resultados em termos do nível de saúde bucal da população. Não obstante, o relacionamento direto entre profissional e paciente continua sendo a modalidade predominante de prestação de serviços e este é certamente o principal motivo para a preferência que, na escolha da carreira universitária, the dão os adolescentes (nos vestibulares de 1992 em São Paulo e no Distrito Federal, p.ex., a procura pelos cursos de odontologia perdeu somente para a medicina).

Os primeiros serviços públicos de atendimento odontológico, direcionados para as camadas de baixa renda, surgiram em capitais das principais unidades federadas por iniciativa dos governos estaduais, inicialmente por ser inevitável ofertar pelo menos alguns serviços gratuitos de urgência e de extrações e, em seguida, para atender à pressão dos Cirurgiões-Dentistas por empregos $(176,229,230)$.

A rede estadual e algumas unidades ligadas a instituiçōes beneficentes expandiram-se gradativamente, sendo depois seguidos pela implantação de serviços por parte de prefeituras de municipios de maior porte. No começo o objetivo era 0 de prestar um atendimento mínimo a pobres e indigentes, mas pouco a pouco surgiram os serviços de saúde escolar, enfatizando o grupo prioritário do ponto de vista odontológico, composto por crianças a partir dos 6 ou 7 anos de idade.

Neste capítulo, o estudo dos programas e das políticas públicas está organizado em torno de cinco tópicos: as ações desenvolvidas a nível central, os projetos preventivos, as iniciativas de nivel regional e local, questões relacionadas como a estrutura de produção e consumo de açúcar no país e o sistema de ensino elementar vigente $e$, por último, uma análise de conjunto particularmente sobre $\circ$ relacionamento entre 0 quadro epidemiológico e os programas setoriais.

\section{: 8.1. O Nivel Central: Avanços e Retrocessos}

No início da década de sessenta é que o governo central, através da Fundação SESP, passou a ter presença no campo da saúde bucal. Antes disso apenas a previdência social possuia algumas unidades de atendimento, com odontólogos contratados pelos institutos de aposentadoria e pensões, na época ligados às categorias profissionais mais importantes $(114,179)$.

Pode-se afirmar que 0 Brasil não possui tradição de normatização e coordenação a nivel central das atividades odontológicas desenvolvidas no país. o setor estabeleceu suas próprias regras pouco a pouco, preocupando-se essencialmente com a área universitária e com 0 seu próprio fortalecimento. Desta maneira, as açōes curativas e os interesses individuais impuseram 0 seu predomínio. A formação de um número grande de CirurgiōesDentistas e a generalização de padrões muito elevados de doenças 
bucais são resultantes lógicas desse "não sistema- de atenção em odontologia.

Na verdade, neste século o universo particular da odontologia conseguiu manter-se liberal e arredio a diretrizes centrais em um país que desde 0 império tem sido centralizador por excelência.

A Lei Eloy Chaves, de 1922, construiu os primeiros alicerces da seguridade social no Brasil, estabelecendo um regime de prestação de benefícios sociais à semelhança dos sistemas implantados pouco antes na Europa e particularmente na Alemanha do Chanceler Bismark. Os serviços de saúde só começaram a se fazer notar com certa representatividade nos anos cinquenta, primeiro com a proteçăp à maternidade e a problemas do trabalho, e depois com cuidados à infância e com internaçōes hospitalares, para finalmente incluirem serviços laboratoriais e de clínica médica e odontológica.

A oferta de serviços curativos odontológicos por parte dos Institutos de Aposentadoria e Pensões, como os que serviam às categorias dos bancários e dos servidores públicos, aconteceu de maneira assistemática e pela modalidade direta (profissionais assalariados que trabalhavam em espaços físicos e em equipamentos pertencentes à instituição empregadora), sempre por livre demanda de pacientes. De nenhuma forma esses serviços podem ser caracterizados como de nivel central, embora pertencessem a uma instituição - a previdência social - de âmbito federal.

o sistema previdenciário mudou gradativamente, observando-se um crescimento cada vez maior da modalidade indireta de prestação de serviços (privatização), na qual os odontólogos são remunerados para tratar, em seus próprios consultórios e com equipamentos e insumos de sua propriedade, a pacientes encaminhados pela instituição securităria, mediante uma tabela de preços previamente acordada. Os serviços continuaram a ser curativos e por livre demanda, com controles frouxos e pouco eficazes. Dessa forma, mesmo sem se constituir em um típico sistema central, a previdência social acabou por plasmar no país um "modelo público" de atenção odontológica, em moldes similares ao pouco antes implantado na área médica. Este modelo contribuiu ativamente para o agravamento dos problemas setoriais, seja por sua reduzida eficácia seja porque acostumou parcela significativa da profissão às suas distorções (baixa remuneração, fraudes compensatórias criando problemas éticos de difícil soluçăo). Mais tarde foi criada uma coordenadoria específica de odontologia no INPS e outra no ex-FUNRURAL, como se refere adiante.

A nivel do Ministério da Saúde as ações odontológicas ficaram a cargo de uma de suas unidades vinculadas, a Fundação SESP, entidade originária do esforço de guerra no campo da saúde pública feito em conjunto com o governo norte-americano. A Fundação SESP (hoje incorporada à Fundação Nacional de Saúde) notabilizou-se principalmente pela implantação de três medidas: fluoretação da água de abastecimento público; sistema incremental de atenção a 
escolares; desenvolvimento de uma rede de serviços nos estados com pessoal próprio a tempo integral.

- Ministério, embora contando com um bom serviço em sua estrutura, optou por conserva-lo em uma posiçāo secundária, com uma cobertura populacional sempre reduzida. Somente em $1982 \mathrm{com}$ um Grupo de Trabalho e em 1987 com a Divisão Nacional de Saúde Bucal passou a desempenhar um papel que pode ser considerado como próximo ao de um núcleo central do sistema(38).

A segunda metade da década de setenta marcou a fase em que propostas mais concretas de planos e programas nacionais começaram a acumular-se sobre as mesas dos dirigentes das principais instituições de saúde nacionais (Ministérios da Saúde $e$ da Previdência, e por vezes também o da Educação), procurando acompanhar o esforço de reorientação e de expansăo do sistema feito na área médica.

Com a aprovação do Programa Nacional de Alimentação e Nutrição - PRONAN - em 1975, no capítulo dedicado às "intervenções nutricionais complementares" foi incluido o combate à cárie dental com recursos suficientes para implementar, até 1980, a fluoretação da água de consumo público nas localidades com mais de 50 mil habitantes(187). A responsabilidade pelo projeto foi dada à Fundação SESP, mediante recursos repassados pelo Instituto Nacional de Alimentação e Nutrição. Ao final do período, contudo, tinham sido beneficiadas apenas 50 cidades com um pouco mais de 4 milhöes de habitantes, correspondendo a algo em torno de $8 \%$ da meta estabelecida. As razōes mais notórias para tais resultados situaram-se nas dificuldades de interação entre um órgão pertencente ao setor saúde e as empresas de abastecimento d'água, a problemas burocráticos ligados à pesada e fortemente centralizada estrutura administrativa da F.SESP e finalmente à redução do poder de compra do programa face à inflação e à demora na aplicação dos recursos.

Em 1987 foi proposta a inclusão de um projeto específico de odontologia como parte do Programa Integrado de Ações de Saúde e Saneamento -PIASS-(182), com base na fluoretação da água e aplicações tópicas de flúor (via bochechos); redirecionamento de recursos humanos e físicos para dar ênfase ao atendimento de escolares; implementação de unidades elementares em localidades sem acesso à odontologia formal, através de pessoal de nível técnico. o projeto incluia o estímulo ao aumento de produtividade, à adoção de equipamentos simplificados e ao emprego de recursos humanos sem formação acadêmica com funções expandidas. Marcado por um conteúdo inovador, considerando-se a época em que foram feitas, o projeto foi aceito mas não chegou a obter recursos para sua execução efetiva devido à maior prioridade conferida à implantação de uma rede de centros e postos de saúde na área médica (mais de 3.500 unidades foram estabelecidas no interior do país).

À mesma época foi apresentada, pelo IPEA (Ministério do Planejamento), uma proposta em bases similares à do PIASS, de apoio a um "programa na área de odontologia", com recursos do Fundo de 
Apoio ao Desenvolvimento Social -FAS(129). O documento alcançou aceitação técnica mas não chegou ao CDS devido à interrupção do fluxo de apresentação e análise de projetos a este organismo.

Um documento sobre "a responsabilidade do Ministério da Saúde na prevenção e tratamento das doenças bucais" de 1978 acabou transformando-se em texto oficial da secretaria Nacional de Programas Especiais de Saúde, conquistando a aprovação pessoal do Ministro da Saúde da época(229). A criação de um núcleo ou setor específico de saúde bucal na estrutura da secretaria, sugerida no documento, não se concretizou possivelmente por entraves burocráticos não superados e também por ter se mantido dentro de limites essencialmente técnicos, sem pressōes para a sua consecução. As posições centrais do texto podem ser resumidas em três itens: generalização de medidas preventivas, prioridade de atendimento à faixa de 6 a 14 anos e simplificação de recursos humanos, equipamentos e demais insumos necessários à atenção básica.

As discussões setoriais concentraram-se à volta do Programa Nacional de Serviços Básicos de Saúde -PREV/SAÚDE(32) - em 1980, num seguimento natural ao PIASS e numa antecipação do Sistema Unificado e Descentralizado de Saude - SUDS - que viria logo após. 0 PREV/SAÚDE tinha como um dos seus componentes importantes a área da saúde bucal, a qual chegou a ser considerada como uma das cinco atividades básicas que deveriam estar presentes em cada unidade de saúde, ao lado da ginecologia/obstetrícia, clínica geral, cirurgia e pediatria. O sub-programa de odontologia(189) foi aprovado no âmbito do programa global e definia três grandes níveis de prestaçāo de serviços: primário, compreendendo a prevenção maciça e a prestação de cuidados elementares; secundário, com atividades de apoio ao primeiro nível e atendimento a escolares de primeiro grau; terciário, com a referência para casos complexos e a oferta de próteses sob lucro zero. Propunha-se uma rede de complexidade crescente com ênfase nas unidades de atenção elementar (situadas geralmente em localidades sem profissional e em periferias urbanas sem assistência) e no emprego de pessoal técnico com funções expandidas, ou seja, THDs (Técnicos de Higiene Dental) que também fariam restaurações dentárias em todas as suas etapas, incluindo o preparo cavitário e dariam atendimento emergencial simples sob supervisão direta ou indireta, sendo empregados exclusivamente pelos serviços públicos. O PREV/SAÚDE não chegou a se constituir em um programa governamental, mas além de representar um momento muito rico e significativo no processo de discussōes setoriais, constituiu-se no ponto de referência para os progressos daí em diante alcançados.

Como resultante da divisão de forças que predominou no setor saúde a partir de 1980, houve um fortalecimento da previdência social. Foi o período do CONASP (Comissão Consultiva da Administração de Saúde Previdenciária), no qual foi aprovado entre outros o "Programa de Reorientação da Assistência Odontológica" do INAMPS em 1983(114). Foi um texto escrito no IPEA e que representa na prática os avanços possíveis naquele período, considerando 0 estágio em que se encontravam as discussões dentro do sistema de 
saúde em seu todo e o que podia ser aceito e compreendido pela coordenação de odontologia do INAMPS. Sua importância maior radicase na oficialização das severas críticas ao regime indireto de prestação de serviços com pagamento de profissionais por tarefa, propondo-se sua substituição por serviços diretos. No INAMPS 0 processo de fortalecimento interno da odontologia conduziu à criação de um Departamento com numerosa equipe e coordenadorias nos estados, mas ao cabo notabilizou-se apenas pela tentativa de implantação de um amplo programa de aplicação de selantes oclusais, que não contou com a aceitação dos profissionais de saúde pública do país e não foi implementado apesar da compra de insumos em grande quantidade.

- surgimento do Fundo de Apoio ao Desenvolvimento Social FINSOCIAL -, logo ocupando um espaço de relevante fonte de financiamento para toda a área social do governo federal, propiciou a aprovação em 1983 de dois programas essenciais para a odontologia: um de apoio à fluoretação da água e outro alocando recursos para ações de saúde escolar(228,230). O primeiro, que sustentou grande parte do processo de expansão da fluoretação no Brasil, ficou a cargo do Banco Nacional de Habitação, depois substituido nesta atividade pela Caixa Econômica Federal. o segundo localizou-se na Fundação de Assistência ao Estudante - FAE - do Ministério da Educação e Cultura, tendo proporcionado verbas significativas para a aquisição de equipamentos simplificados e para os programas preventivos a base de bochechos com fluoreto de sódio.

Com o término do regime militar, instalou-se a Nova República. Em seus primórdios, a política geral de saúde e um plano de saúde bucal foram apresentados ao então candidato à presidência Dr. Tancredo Neves( ${ }^{(\theta)}$.

As Conferências Nacionais de Saúde ocorridas nos anos oitenta concederam espaços representativos à odontologia. Na VII Conferência o grupo que relatou o sub-tema "odontologia e os serviços básicos de saúde" recomendou um programa em três níveis, similar ao sugerido no PREV/SAÚDE e incluindo entre outros pontos a institucionalização de um setor odontológico no Ministério da Saúde, a aprovação do Técnico Dental operador, concessão de recursos para expansão do setor público e produção de insumos básicos via central de Medicamentos. Na VIII realizou-se, como consequência, a I Conferência Nacional de saúde Bucal, cuja importância principal está na participação de entidades de representação popular com a ampliação do fórum de debates. Suas propostas seguem os princípios e diretrizes então adotados na área de saúde em geral, sugerindo un programa de saúde bucal universalizado, hierarquizado, regionalizado e descentralizado tendo por base a municipalização, a estatização dos serviços e a participação popular. As prioridades aconselhadas - faixa de 0 a 14 anos, gestantes, adultos - não podem ser consideradas técnicamente como corretas, além de que algumas propostas de nítido cunho corporativista chegaram a ser incluidas na pauta de reivindicações, como piso salarial de 10 salários-mínimos e insalubridade máxima para os odontólogos $(48,66,67,176)$. 
Entre as muitas conclusōes que podem ser tiradas sobre a breve retrospectiva feita nos tópicos precedentes, está a de que a luta pela implantação de um eficaz sistema público de atenção odontológica no Brasil obteve avanços significativos mas limitados em termos de uma efetiva melhoria dos níveis de saúde bucal e de uma maior cobertura populacional. Dentro de un quadro caracterizado por um país em constante crise econômica e por uma profissão ainda essencialmente liberal e conservadora, tornou-se possível reunir forças suficientes para estabelecer propostas qualitativamente factiveis, mas insuficientes para de fato chegarem ao nível da execução em massa. Os recursos disponíveis para açōes de saúde bucal resumiram-se às dotações da previdência social, de evidente mau uso (apoio à privatização, ausência de programas inclusive para os serviços próprios, ênfase em atividades curativas, tentativas equivocadas no campo preventivol, ao apoio à fluoretação da água via FINSOCIAL e ao limitado orçamento da F.SESP.

Um Grupo de Trabalho denominado Unidade de Sistema de Odontologia ou GT/ODONTO surgiu no Ministério da Saúde em 1982. Sua mais evidente contribuição foi dada no campo preventivo, através do apoio à fluoretação da água implementada pelo $\mathrm{BNH}^{(228)}$.

Somente em 1987 é que, na estrutura da Secretaria Nacional de Programas Especiais de Saúde foi criada a Divisão Nacional de Saúde Bucal -DNSB-(3a) consolidada na estrutura do Ministério de 1988 . 0 orçamento da União de 1989 apresenta a particularidade de conter, pela primeira vez, dotação especifica para ações de saúde oral (NCz\$2,2 milhões, com execução final de $\mathrm{NCz} \$ 20$ milhões) (30).

Com base no Levantamento Epidemiológico realizado em 86 , a Divisão adotou uma linha sequencial de planejamento em saúde, definindo inicialmente uma Política Nacional de Saúde Bucal para, em seguida, conseguir recursos para implementar o Programa Nacional de Prevenção da Cárie Dental - PRECAD.

A Politica Nacional de Saúde Bucal(40), aprovada pelas instituições públicas e pelas entidades de classe, definia como prioritários, pela ordem, as crianças de 6 a 12 anos, adolescentes de 13 a 19, infantes de 2 a 5 e depois os adultos. Além disto, privilegiava os serviços emergenciais, ações preventivas $e$ educativas num mesmo patamar $e$ em terceiro lugar os serviços recuperadores básicos, destacando a cárie dental e as doenças periodontais como os principais problemas a serem enfrentados. 0 texto da Politica contemplava un conjunto de princípios, objetivos e prioridades, além de diretrizes operacionais (de mais curto prazo), chegando a estabelecer como um de seus objetivos a redução em 508 da prevalência da cárie dental em crianças e adolescentes no prazo de dez anos.

- programa preventivo(39,51) lançado em seguida caracterizava-se principalmente pela decisão de apoiar projetos de ampla cobertura populacional, abandonando as atividades de pequena abrangência e os "projetos-piloto" muito comuns até então. As metas para o primeiro ano de execução (1989) foram, entre outras, de aplicação tópica de fluoretos em 4 milhões de crianças e de expansão da fluoretação da 
água para atingir 70 milhōes de pessoas. Na prática o programa repassou aos estados e municípios todo 0 material preventivo necessário para uso tópico em 7 milhões de crianças, chegando a água com flúor a 64 milhões de habitantes, além de outros 6 milhōes para os quais foram repassados recursos às companhias de abastecimento responsáveis (uma melhor análise destas ações está nos Títulos 8.2.1. e 8.2.4.).

Nesta fase inicial da DNSB diversas atividades de importância foram desenvolvidas: cursos para agentes básicos de saúde geral que atuavam em localidades sem Cirurgiāo-Dentista; normas para controle e registro de dentifrícios fluoretados e de soluções para enxaguatórios diários com flúor; estudos sobre a viabilizaçāo do uso do sal de cozinha como veículo preventivo (conclusões negativas), sobre o sistema de ensino de 10. grau para viabilizar 0 tratamento odontológico do alunado, sobre outros métodos preventivos tópicos (vernizes, soluçōes altamente concentradas); editoração de textos de saúde pública inclusive sobre controle de infecção e combate a manifestaçōes de AIDS e câncer bucal. Na área internacional, a Divisão chegou a firmar acordos especificos de cooperação com suas congêneres de Cuba e Guatemala e com a Universidade de Londres, tendo realizado um Fórum Internacional de Saúde Bucal com a presença de numerosos especialistas extrangeiros e assumido a direção da Coordenadoria de Serviços Odontológicos da América Latina - COSAL $(33,35,41,42,43,48)$.

- apoio à estratégia de cunho populacional para combater a cárie dental e para expandir os serviços básicos caracterizaram esta fase. Embora tenha sido interrompida com a troca de governo, sem dúvida essa estratégia marcou uma mudança no comportamento e na maneira de enfrentar os problemas de importância epidemiológica por parte de muitos profissionais de saúde pública no país, na prática iniciando um novo ciclo nesta área.

\section{: 8.2. A Prevenção da Cárie Dental no Brasil}

Ao longo das últimas décadas, e de modo especial a partir dos anos sessenta, diversos projetos, programas e ações isoladas tem sido experimentadas no campo preventivo, com objetivo de beneficiar - conjunto da população. Os resultados alcançados, apesar de todos os esforços feitos, podem ser considerados como débeis em seu conjunto, tendo em vista que os índices de ocorrência da principal das doenças bucais - a cárie dental - permanecem muito elevados e somente decresceram de maneira pontual, em algumas localidades. Outras problemas de saúde pública, como as doenças periodontais e 0 câncer bucal, têm ficado virtualmente à margem das politicas públicas.

Mais recentemente surgiu o que se pode denominar de um período de acirramento das discussões, com a multiplicação de projetos preventivos, de cursos e seminários nos congressos profissionais, da expansão da oferta e venda de produtos comerciais destinados ao controle da cárie e das doenças periodontais, do crescimento do mercado consumidor de produtos preventivos principalmente dentifrícios e soluções de higiene oral, aparecimento de núcleos de 
influência de escolas de países desenvolvidos (mormente da área escandinava), fortalecimento da profissão de Técnico de Higiene Dental e maior oferta de literatura especializada. Ainda não se pode falar em um "boom" preventivo, porque a população ainda não consegue efetivamente beneficiar-se dessas discussões e iniciativas, mas é possivel que cheguemos a este ponto.

A importância mais notória da análise feita a seguir está em que ela abre uma porta para a identificação de êrros ou falhas no passado recente, permitindo uma melhor visão sobre os caminhos a trilhar de ora em diante. São enfocadas as linhas de fluoretação da água e do sal, os bochechos com fluoreto de sódio, as aplicações de flúor-fosfato acidulado e de selantes, as terapias intensivas e os dentifrícios fluoretados. Adicionalmente, recomenda-se a leitura do texto sobre as modalidades de financiamento (Título), no qual está comentado o direcionamento de recursos previdenciários para algumas ações de prevenção.

\section{:: 8.2.1. Fluoretação da Água de Consumo Público}

A implantação da primeira planta de áqua fluoretada no Brasil deu-se em 1960 na cidade de Baixo Guandú, no Espirito Santo, em estação de tratamento pertencente à Fundação SESP (Serviços de Saúde Pública), do Ministério da Saúde(95).

Desde aí a idéia ganhou cada vez mais adeptos e não cessou de crescer por todo o país. Nos anos sessenta houve uma extraordinária expansão no estado do Rio Grande do sul que se transformou, junto com o Chile, em área exemplar neste campo a nível internacional. Embora o amplo programa gaúcho de fluoretação da água tenha sido interrompido no início dos anos setenta, o método terminou se impondo como a grande linha de prevenção da cárie dental no país.

Em 1974 foi assinada a Lei 6050 que obrigou a adição de flúor em novas estações de abastecimento. Em 1977 uma linha de apoio financeiro a nível federal que foi embutida no PRONAN - Programa Nacional de Alimentação e Nutrição - não conseguiu prosperar, mas em 1983 foi aprovada a destinação de recursos do FINSOCIAL que entre 84 e 89 propiciou um notável aumento no número de localidades cobertas $(67,129,187,189,228)$.

Coincidindo com a abertura da linha de apoio financeiro federal via Banco Nacional de Habitação e depois via Caixa Econômica Federal, o estado de São Paulo e a cidade do Rio de Janeiro adotaram a fluoretação como prioridade.

Ao lançar o Programa Nacional de Prevenção da Cárie Dental PRECAD-(39,51) o Ministério da Saúde em 1989 colocou a fluoretação da água como sua primeira linha de ação. Na prática, formou-se um grupo de coordenação conjunta do trabalho, composto por técnicos da Divisão Nacional de Saúde Bucal e do Departamento de Saneamento, este da Caixa Econômica, visando unificar as formas de financiamento e de atuação. 
Estudo feito com base nas informaçōes diretamente fornecidas pelas Companhias de Abastecimento D'Água dos estados e municípios constatou que, em 1989, 1.222 localidades dispunham de água artificialmente fluoretada, abrangendo 62 milhões de moradores(52). Neste período, as cidades que interrompiam a dosagem regular de flúor à água eram visitadas por especialistas da DNSB e da CEF a fim de definir estratégias alternativas para a retomada do processo.

Todo este esforço fez com que 0 programa brasileiro se constituisse no que mais se expandiu a nivel mundial nos anos oitenta(78,190), superando inclusive programas tradicionais como os dos Estados Unidos e da Comunidade dos Estados Independentes (exURSS). A exceção coube ãs cidades-estado de Cingapura e Honk Kong, as quais conseguiram beneficiar com 0 método a $100 \%$ de suas populaçōes $(84,181)$.

Nos paises industrializados que já conseguiram controlar a cárie dental, discute-se hoje com maior intensidade se os efeitos da fluoretação são pré ou post-eruptivos, principalmente em função das crescentes evidências favoráveis à ação tópica do flúor. No atual estágio de conhecimentos, aceita-se que: (a) os efeitos sistêmicos(pré-eruptivos) estão sempre presentes e jogam um papel fundamental principalmente em populações sujeitas a altos indices de ataque de cárie, como é o caso do Brasili (b) o flúor local (post-eruptivo) possui um ativo poder preventivo, tanto nos métodos de ingestão quanto nos de aplicação tópica $(11,58,75,80,96,137)$.

Estudos feitos em comunidades submetidas com regularidade ao método mostram reduçōes na prevalência de cárie similares às obtidas nos estudos internacionais $(6,227,228,232)$. Considerando que a verdadeira expansão a nível nacional aconteceu a partir da segunda metade da década de setenta, ainda não estão disponíveis estudos relativos aos impactos recentes em termos populacionais sobre a saúde bucal de escolares de $1 \%$. grau.

A história da fluoretação no Brasil é extraordinária no sentido de que sua progressão e gradativa afirmação se deram em um país no qual, em qualquer setor, poucas atividades conseguiram resultados similares. Certamente um processo com esta trajetória, deve ser respeitado e ter continuidade. A Tabela 38 resume 0 desenvolvimento do método no país.

Com a mudança de governo federal em 1990, diminuiu temporariamente a ênfase até então dada ao método. o programa conjunto com a CEF foi desativado; as linhas de financiamento federal disponiveis desde 84 deixaram de existir; o sub-programa 1 do PRECAD, de apoio direto a esta medida preventiva não teve continuidade e, finalmente, as regiōes Norte, Nordeste e Centro Oeste passaram a ser consideradas como áreas de implantação de um novo e concorrente método (fluoretação do sal de cozinha) $(165,188,212)$. Nas regiōes sul e sudeste e no Distrito federal tornou-se necessária a organização de entidades de saúde pública e de representação de classe para defender a manutenção da fluoretação da água, além de re-explicar para a população o valor da medidà e 
evitar que os administradores das Companhias de Abastecimento D'Água (as quais costumam resistir à compra de flúor sob o argumento de que ocasionam despesas adicionais em tempos de crise) simplesmente a suspendessem com base na mudança da política central.

Em São Paulo, a Associação Paulista de Cirurgiōes Dentistas lançou um programa preventivo que em essência estabelece um controle mais rígido e contínuo sobre a dosagem correta na água(188). O sistema de vigilância sanitária foi iniciado em 1989 pela DNSB(51), que chegou a firmar convênios e fornecer recursos à Universidade Federal de Alagoas (sistema acessivel aos estados do Norte e Nordeste) e com a Prefeitura Municipal de São Paulo para implantação de controle periódico do teor de flúor na água(209.210). O Paraná também adotou esta prática e a Associação Brasileira de Odontologia apoiou a sua utilização em outros estados $(1,51,156,169)$.

- futuro da fluoretação da água de consumo público no Brasil, como método de saúde pública de real efetividade na redução da cárie dental dependerá por um lado da capacidade de compreensão e de organização dos odontólogos e, por outro lado, da demonstração consistente de resultados preventivos positivos notadamente nos estados onde tem extensa presença, como é o caso de São Paulo, Rio de Janeiro, Minas Gerais, Paraná, Santa Catarina, Rio Grande do sul e Distrito Federal há problemas sérios de sub-dosagem e de interrupções por períodos breves ou longos em muitas cidades, fazendo com que este não seja um processo uniforme no país e transformando o controle de qualidae (vigilância sanitária da fluorentação) em uma linha de fundamental importância pra assegurar a sua consolidação. 
TABELA 38

CIDADES E POPULAÇÃO COM ÁGUA FLUORETADA

POR REGIĀO. BRASIL, 1972 A 1989.

\begin{tabular}{l|rrr|r|r|r|r|r}
\hline REGIÁO & \multicolumn{4}{c|}{ CIDADES } & \multicolumn{4}{c}{ POPULACÁ(mil) } \\
\cline { 2 - 9 } NORTE & 1972 & 1977 & 1982 & 1989 & 1972 & 1977 & 1982 & 1989 \\
\hline NORDEST & 11 & 54 & 83 & 82 & 430 & 1989 & 6204 & 8876 \\
SUDESTE & 33 & 57 & 216 & 860 & 1480 & 3279 & 11867 & 40313 \\
SUL & 30 & 120 & 134 & 243 & 979 & 4308 & 4210 & 10863 \\
C-OESTE & 2 & 2 & 4 & 33 & 450 & 711 & 1809 & 3730 \\
BRASIL & 76 & 235 & 444 & 1222 & 3339 & 10772 & 25757 & 64003 \\
\hline
\end{tabular}

("): 1107 cidades e 115 distritos.

Fontes: Bibliogratias 52,56,95,179. 
:: 8.2.2. Fluoretação do Sal de Cozinha

Não obstante tenha alcançado um tratamento de destaque por parte da Organização Mundial da Saúde que o coloca como segunda opção após a fluoretação da água, o método de adição de fluoretos ao sal de cozinha obteve escassa repercussão como método preventivo de massa em todo o mundo, com as conhecidas exceçōes da Suiça, Hungria e das recentes tentativas de sua implantação em alguns países da América Latina(59,145,160,168,180,192).

No Brasil, ganhou maior status em 1990, por iniciativa do Ministério da Saúde no começo do governo do Presidente collor de Mello, estabelecendo como áreas de comercializaçāo do sal fluoretado as regiōes Norte, Nordeste e Centro-Oeste, nesta última com exceção do Distrito Federal e do Mato Grosso do Sul(188,212), apesar de que recente estudo solicitado pelo próprio Ministério se posicionasse contrariamente à adoção do método no Brasil(219).

Problemas ligados à produção de insumos nacionais e ao processo de adiçāp de fluoretos ao sal refinado e grosso passaram a ser estudados junto às empresas salineiras, prevendo-se análises sobre a concentração de íon flúor natural nas águas, possivelmente com o intuito de evitar o risco de fluorose dentária por superdosagem ocasionada pela combinação de duas fontes de ingestão (na água e no sal).

Os efeitos preventivos potenciais do método sāo similares aos da fluoretação da água, assim como seus niveis de excreção urinária de excessos.

As barreiras para que se transforme em una medida de saúde pública efetiva situam-se principalmente no terreno prático, envolvendo questōes ligadas à comercialização do sal, às variaçōes de consumo e à aceitação pelos estados e municípios.

Em pesquisa efetuada em onze capitais brasileiras(107), constatou-se um consumo alimentar domiciliar per capita médio de 9,29 gramas de sal/dia, predominando o sal refinado $(8,87 \mathrm{~g})$ sobre 0 sal grosso $(0,22 \mathrm{~g})$, o glutamato monossódico $(0,18 \mathrm{~g})$ e 0 sal dietético $(0,02 \mathrm{~g})$. A variaçāo entre as médias extremas de $6,14 \mathrm{~g}$ de Salvador e de $10,76 \mathrm{~g}$ no Rio de Janeiro (diferença diária de 4,62g equivalendo a 1758) pode ser considerada como muito forte. As pessoas de baixa renda consomem mais e gastam proporcionalmente mais com sal do que as de alta renda. No Rio de Janeiro p.ex. os gastos com sal representam 0,608 das despesas com alimentação nas famílias que ganham até dois salários-mínimos, e 0,12z nas de 30 ou mais salários. Parece evidente que uma melhor análise da estrutura de consumo torna-se necessária antes de oficializar o processo de fluoretação do sal, a fim de evitar riscos de fluorose em parte representativa da população.

Recentemente, odontólogos do setor público das regiões Norte, Nordeste e Centro Oeste reunidos durante encontro nacional em São Paulo (79) assumiram posição contrária à adoção do método em seus estados argumentando entre outros pontos que: (a) não fora dada 
opção de escolha a cada estado ou cidade para decidir que método preventivo deseja implantar; (b) o processo não foi democraticamente discutido com os interessados; (c) a expansão da rede de abastecimento d'água de boa qualidade é prioridade básica para as populaçõoes dessas regiões e a principal maneira que a classe odontológica tem de participar dessa luta é através da fluoretação da água; (d) o sal tem sido condenado pela classe médica que combate problemas de hipertensão; (e) os recursos a serem despendidos com a aquisição de fluoretos para colocar no sal de cozinha podem alternativamente ser utilizados para solucionar alguns dos problemas que tem dificultado a manutenção e a expansão da fluoretação da água. As Secretarias da saúde da cidade e do estado de são Paulo firmaram nota condenando o método(208).

As discussões concentram-se em torno de três pontos. Em primeiro lugar, como evitar a venda de sal com flúor em cidades que já possuam dosagem ótima na água. A Secretaria de saúde da cidade de Santos divulgou declaração orientando a população local a não consumir sal proveniente do nordeste que contivesse flúor, pois poderia ocasionar fluorose considerando que a água local é fluoretada. A solução para este problema estaria em (a) produzir um sal com flúor para o Norte, Nordeste e Centro-Oeste e outro sem flúor para Sul, Sudeste, Distrito Federal e Mato Grosso do Sul, com preços similares; (b) ofertar os dois tipos em todas as cidades e deixar que cada consumidor compre o que lhe aprouver; (c) permitir que no Sul e Sudeste (mais DF e MS) o sal com flúor tenha preço bem mais elevado para desestimular sua compra, além de colocar uma tarja nos pacotes informando que é prejudicial à saúde dado o risco de fluorose, ou (d) desativar no país a fluoretação da água e tentar implantar nacionalmente o método concorrente.

Acordos sólidos com os empresários do setor salineiro, numa economia aberta como a brasileira, dificilmente podem ser concretizados. A livre escolha pela população se por um lado é mais democrática, por outro lado pode resultar em níveis muito altos ou muito baixos (sem controle) de consumo, não impedindoo o possivel surgimento de casos de fluorose. O aumento de preços não se justifica e muito menos o corte da fluoretação da água.

Em segundo Iugar discute-se como assegurar um sistema eficaz de controle e de correção de eventuais sub ou super-dosagens, considerando que a força preventiva do método depende em grande parte disto(168) e que uma fiscalização adequada não é comum em relação a outros produtos alimentares bem mais críticos para 0 consumo público.

Por último, há o problema de como garantir recursos novos para adquirir, através do Ministério da saúde, o fluoreto para fornecimento às salineiras, uma vez que é isto que é feito com relação ao iodato de potássio para combate do bócio endêmico. As linhas de apoio financeiro à fluoretação via CEF e DNSB foram interrompidas e agora os fundos necessários para o novo método devem sair do orçamento da Fundação Nacional de Saúde, numa disputa com verbas para outros setores, a cada ano. 
:: 8.2.3. Bochechos com Fluoreto de Sódio

Os bochechos com soluções de fluoreto de sódio a 0,28 , feitos semanalmente nas escolas, difundiram-se no Brasil quase ao mesmo tempo que nos Estados Unidos, desde que o método ganhou foro de medida de saúde púlica com a eliminação da exigência de profilaxia prévia.

Os primeiros programas foram implementados pela secretaria Municipal de Saúde e Serviço Social da cidade de Porto Alegre(181) e pela Fundação SESP(89) em 1971. Logo, foi adotado por Secretarias de Educação e de Saúde em quase todo o país. No Paraná, no Rio Grande do Sul, em São Paulo e em alguns outros estados, ainda hoje são praticados em larga escala, podendo-se dizer que sua tecnologia de utilização conseguiu incorporar-se aos conhecimentos usuais dos que manejam programas de atenção a escolares de 12 grau a nível regional e local $(48,169)$.

Segundo os trabalhos de Ripa e Horowitz(102,194,197,198), cerca de vinte e cinco sessões semanais por ano, sem soluções de continuidade notáveis, são suficientes para alcançar uma redução em torno de $31 \%$ com este método.

Estudos brasileiros são escassos, referindo-se a pesquisas ou a contingentes limitados de escolares $(56,180)$. Já em 74 o autor, observou que na prática o número de bochechos feitos por ano em escolas públicas era de dezoito, em média. Análises de programas, feitas posteriormente em vários estados, chegaram a resultados similares. Os períodos de interrup̧ão, nas escolas brasileiras, podem ser longos, frequientes ou ambos os casos. Afora as férias regulares, diversos alunos deixam de frequentar a escola em meados de novembro por terem alcançado notas suficientes à promoção, outros ausentam-se para apoiar financeiramente a familia, e as greves de professores por melhores salários tornaram-se habituais face à crise econômica que assola o país.

Estudos de Montenegro e Oliveira(157), que são discutidos mais detalhadamente no Título 8.4 .2$.$) revelam que 45 \%$ das matrículas do ensino fundamental ( $1^{\text {a }}$ à $8^{\mathbf{a}}$ série) são gastas com alunos que se evadem do sistema.

No Levantamento Epidemiológico nacional(34), as crianças residentes em localidades com programas tradicionais de bochechos não apresentaram condiçōes de saúde bucal superiores às das demais cidades. $\mathrm{Na}$ verdade, os altos índices CPO-D constatados nas crianças de 6 a 12 anos mostraram que as linhas preventivas em ação não foram eficazes.

Por que o método dos bochechos com fluoreto de sódio não proporcionou os resultados esperados no Brasil? Não se pode culpar o método em si, mesmo porque os seus efeitos continuam sendo tão positivos quanto antes, e sua execuçāo é simples e tem baixo custo. - fracasso na maior parte das cidades deve-se a que o método pressupõe um funcionamento regular das escolas e da própria unidade de saúde, embora isto dificilmente aconteça no Brasil. Assim, todo 
e qualquer método que dependa da presença contínua e regular da clientela, só consegue êxito em locais cuja estrutura assegure o cumprimento destas pré-condiçōes. Em saúde pública a melhor linha preventiva é aquela que em um número mínimo de sessōes (se possível uma só como no caso da vacina contra a febre amarela) proporcione o máximo benefício. A alternativa está na adoção de hábitos preventivos adequados pelas pessoas, mas no caso dos bochechos as soluçōes de baixa concentração - NaF a 0,058 para uso caseiro diáriio - têm pouca aceitação popular.

Baseado em informações dessa ordem, a DNSB sugeriu que os programas à base de bochechos fluoretados deveriam ser reanalisados criticamente, sendo mantidos apenas aqueles que conseguissem superar as dificuldades e assegurar resultados preventivos reais $(50,51)$.

\section{:: 8.2.4. Aplicações Tópicas com Fluoretos}

A aplicação tópica de gel flúor-fosfato acidulado (gel FFA, que contém fluoreto de sódio a 1,238 em solução de ácião ortofosfórico a $0,1 \%$ ) através de moldeiras semestralmente em crianças de 6 a 12 anos de idade foi uma das estratégias preventivas escolhidas pelo PRECAD a nivel nacional em $1989(39,45,51)$.

A base teórica do programa já constava no documento da "Política nacional de saúde bucal"(40).

A escolha do método foi uma consequência da estratégia populacional adotada, adaptando-se ao princípio de que para conseguir reduçōes palpáveis na incidência de cáries no país era necessário fazer com que a prevenção de fato chegasse a todas as crianças ou à maior parte delas. Era uma tentativa de quebrar a tradição de programas destinados a pequenas comunidades e sem impacto global $(80,100)$.

A aplicação de gel FFA duas vezes ao ano propicia uma redução média na ocorrência de novas cáries da ordem de $28 \%$ de acordo com Ripa $(195,197)$. Estudo recentemente publicado pelo National Institute of Dental Research dos Estados Unidos (GIFT,1991) estima uma redução entre 30 e $40 \%$. Aplicações únicas no ano também são benéficas (redução esperada entre 20 e 228 ). Os efeitos se mantém mesmo após 1 a 2 anos de interrupção das aplicações(133). Os riscos consequentes à ingestão eventual do gel tem sido amplamente analisados, principalmente nos países que após reduzir a incidência de cáries enfrentam problemas de super-administração de compostos de flúor $(15,77,125,135,224)$. O método é considerado seguro, pois não ocasiona fluorose nem lesões nos tecidos $(15,55,161,186,195,197,198)$.

Tradicionalmente considerado como um método para uso em clínica particular, sendo de custo elevado e exigindo cerca de quinze minutos por paciente, o gel FFA passou a ser viável para uso em saúde pública em função de dois avanços fundamentais: (a) a exemplo do que ocorrera com os bochechos, constatou-se que a profilaxia prévia não era necessária $(13,60,103,196,198)$; b) o tempo médio 
de aplicação e os custós foram drasticamente reduzidos com 0 desenvolvimento de uma metodologia de aplicação em fluxo contínuo por parte do próprio PRECAD(45,164).

A nova metodologia fundamentou-se no trabalho em equipe, destinando uma função especifica a cada um dos componentes - em geral seis, trabalhando na busca das crianças em sala, organização do ambiente de trabalho, aplicação do gel, preenchimento das moldeiras, controle de tempo e apoio no momento da remoção do gel pela própria criança - e utilizando moldeiras duplas com alça de modo a evitar que o toque do operador na boca da criança, o que representaria tempo adicional pela necessidade de lavar as mãos a cada intervalo. Ainda que cada um permaneça 4 minutos com 0 gel, 0 tempo médio total é reduzido a cerca de 20 segundos por criança. 0 custo nesse programa foi de aproximadamente 0,15 dólares per capita.

No final de 1989 e início de 1990 o Ministério da Saúde custeou e entregou aos estados e municípios 7 milhões de moldeiras duplas, tubos de gel e toalhas de papel para garantir a primeira aplicação em igual número de crianças distribuidas por todas as unidades federadas(50). As quantidades de crianças foram definidas pelos estados e municípios, sob o critério geral de que, nessa primeira vez de uso tópico de fluoretos em massa, seriam viabilizadas todas as solicitações no limite de 85 a 908 do total de crianças de 6 a 12 anos residentes em cada localidade abrangida pelo programa.

Para a segunda aplicação, prevista para o 1 semestre de 1990, os pedidos encaminhados ao Ministério incluiam 9 milhões de crianças. A continuidade deste processo inevitavelmente asseguraria uma diminuição na incidência de cáries no país. Estudo realizado no Distrito Federal e região do entorno, utilizando a mesma metodologia do PRECAD, com duas aplicações de gel FFA (uma por semestre) acompanhadas apenas por orientação educativa, alcançaram os seguintes resultados após um ano: em crianças de 6,8 e 10 anos vivendo em área sem fluoretação da ăgua reduções CPOD respectivamente de $32 \%, 30 \%$ e $29 \%$ na incidência de cáries; nos mesmos grupos etários de localidades com flúor na água reduçōes de 298, $27 \%$ e 248 (174). Estes resultados, que devem ser vistos com cautela por se referirem a um período de um ano, são basicamente compatíveis com os resultados obtidos em pesquisas realizadas em outros países $(55,60,64,80,100,102,103,125)$.

Ocorreu um retardamento na entrega dos insumos (prevista para outubro/89 e viabilizada ao final de novembro/89) causado pela empresa que perdera a licitação, fazendo com que devido ao término do ano letivo a 19 aplicação ficasse em muitos casos para o início do semestre inicial de 1990. Na troca de governo, ocorrida no período de ativa implementação do método, a equipe de coordenação do programa foi substituida. A nova coordenação não lhe deu continuidade e não mostrou interesse em conhecer seus resultados junto aos estados e municípios. Coincidindo com essa fase, um parecer elaborado pelo técnico que antes tentara implantar um projeto com selantes através do INAMPS(88), posicionava-se 
contrariamente ao método de aplicaçōes tópicas com gel flúorfosfato acidulado. Mas as razões apresentadas (relação custobenefício desfavorável, complexidade de execução), baseadas apenas em análises feitas para o mercado norte-americano $(90,191,195)$, mostraram-se inconsistentes para o caso brasileiro.

Como nenhum outro método de abrangência populacional foi desenvolvido em substituição a este, na prática o país voltou, no início da década de noventa, aos programas de cobertura restrita e á estratégia de avanço gradual.

Alguns dos aspectos envolvidos neste processo merecem ser considerados:

(a)a metodologia de aplicação coletiva e principalmente a estratégia populacional são, no caso brasileiro, conceitos novos que exigem algum tempo de maturação para serem compreendidos e de fato incorporados à prática usual dos programas a nível regional e local;

(b) a implantação de novas idéias em prazos reduzidos, sob a contingência das frequentes trocas de governo, ainda que muitas vezes seja inevitável, prejudica a sua absorção pelo nível local;

(c) no estágio de desenvolvimento e de crise econômica vividos pelo pais, os compromissos da maioria das lideranças odontológicas raramente situam-se no âmbito técnico, sendo ainda predominantemente corporativistas ou ligados à luta política geral. Para os diversos grupos instalados nas entidades de classe $e$ nas instituições govenamentais, torna-se difícil nessa conjuntura apoiar de maneira perene a programas originados em outras alas". A Política nacional de Saúde Bucal (40) tentou um acordo em torno de diretrizes e princípios básicos para a naçāo, chegando a conseguir a assinatura pessoal dos vários dirigentes nacionais e regionais, mas esta linha mostrou-se insuficiente no médio prazo pois as lutas internas (gremiais e/ou partidárias) acabam determinando variaçōes de opinião e mudanças de posiçōes que prejudicam os programas técnicos;

(d) o hábito de interrupgão de programas nas trocas de administração pública ainda é comum e em geral aceito como uma fatalidade inevitável, desestabilizando tanto as más como as boas idéias.

Com o passar do tempo, gradativamente a nova metodologia de aplicação tópica em massa e a estratégia de base populacional começaram a ser praticadas em um número crescente de municípios, (percorrendo uma via centrípeta. A consolidação ou não desses conceitos não depende unicamente do setor odontológico. Está em boa parte ligado aos destinos em particular do setor saúde de ora em diante, na expectativa da tendência predominante: ênfase e reforço dos programa públicos sucesso da estratégia populacional ou privilegiamento da iniciativa privada (vitória da privatização e da estratégia de avanço gradual). 


\section{$:: 8.2 .5$. Selantes Oclusais}

Nos anos de 1987 e 1988 o INAMPS intentou promover a aplicação de selantes em escolares de 19 grau, com base nos significativos coeficientes de retenção em fóssulas e fissuras oclusais obtidos em diversos estudos $(91,104,150,151,152,193,199)$.

A técnica de aplicação proposta substituia a profilaxia pela escovação prévia e voltava a utilizar a metodologia das quatro cadeiras simultâneas adotada pela Fundação SESP no início da década de sessenta para fluoretação tópica.

Não obstante as caixas de selantes tenham sido compradas e enviadas aos estados, o programa não chegou a ser implementado. Os estados e municípios contestaram ativamente o projeto, argumentando que não fora discutido localmente e que a terapia com selantes para ser eficaz numa população com níveis muito altos de cáries também em superfícies lisas, precisaria estar associada ao uso de fluoretos.

Num período de fortes modificações estruturais no INAMPS, com a implantaçāo do Sistema Descentralizado e Unificado de Saúde SUDS - a coordenação do programa foi substituida pouco antes da efetivação do projeto. As caixas de selantes que, passado o tempo, conseguiram manter sua validade, foram gradativamente distribuidas a Universidades e a entidades interessadas.

\section{:: 8.2.6. Terapia Intensiva}

A linha de utilização de fluoretos em baixas dosagens e elevada frequência vem obtendo um crescente número de adeptos no Brasil, na esperança de reproduzir aqui os êxitos alcançados nos países industrializados, de modo particular na região escandinava.

O tratamento intensivo com fluoretos, segundo cury e outros(74,186) desenvolve-se dentro do seguinte esquema:" (a) no início, é feita pelo menos uma aplicação tópica semanal de flúor, durante um mês; (b) o paciente recebe orientação quanto ao controle de placa, dieta e uso de fluoretos em dentifrícios e bochechos; (c) - tratamento restaurador é realizado; (d) o período de fluorterapia intensivo é repetido de imediato ou mais tarde em função do risco de cárie do paciente, medido através da sua maior ou menor participação no uso de fluoretos $e$ do controle de placa em consultório, frequência de consumo de açúcar e da paralização ou reversão de manchas brancas no esmalte, além do não surgimento de novas; (e) na primeira avaliação feita com um mês, o retorno do paciente é marcado para dentro de dois meses, sendo gradativamente espaçado para 4,8 meses, etc.".

Variações desse modelo têm sido tentadas. Loureiro(140) na cidade de Thimoteo/MG intensificou ainda mais o processo, incluindo p.ex. a paralização de cáries com material restaurador provisório, atenção endodôntica e atendimento mais frequente dos pacientes, no que curiosamente denominou de "modelo de inversão da atenção odontológica". 
Nas populações submetidas a estes procedimentos os resultados tem sido bastante positivos, havendo poucas dúvidas de que a metodologia de risco(141) e intensiva produzem efeitos preventivos favoráveis.

Sua viabilidade, no entanto, produz-se basicamente em três situações: I. em comunidades e grupos com pequeno número de pessoas; II. em localidades com a cárie dental sob controle, apresentando indices baixos ou médios; III. como estratégia complementar à estratégia populacional.

Em populações numerosas e sujeitas a altos índices de cáries, como acontece na grande maioria das cidades brasileiras, constitui um êrro empregar a estratégia de avanço gradual como um substitutivo aos programas de base populacional. Neste caso, é essencial contar com medidas de abrangência realmente coletiva para forçar a redução dos índices gerais de cárie a níveis nos quais a discriminação de pacientes pelo risco se torne viável.

De acordo com as orientações da organização Mundial da Saúde para países em desenvolvimento(218), a redução das principais doenças bucais pode ser alcançada com: "(a) adoção de uma estratégia populacional para reduzir cáries dentais, aumentando a disponibilidade de flúor onde seus níveis forem insuficientes; (b) redução do total de açúcar consumido; (c) incremento dos padrões gerais de higiene e, em particular, de higiene oral a fim de reduzir a quantidade de placa na maioria da população a níveis que levem à preservação de um periodonto de suporte compativel com a manutenção de uma dentição natural estética e socialmente aceitável ao longo da vida. Este esquema pode ser complementado por uma estratégia de risco".

Numa tentativa de forçar a implementação dos esquemas intensivos de prevenção, em 1991 o regime de custeio de atos odontológicos credenciados e conveniados com 0 INAMPS foi modificado, privilegiando principalmente medidas preventivas típicas destè modelo (37). Embora aparentemente se afigure como correto remunerar melhor as açōes preventivas, este sistema apresenta a desvantagem de manter intacta a estrutura de privatização (pagamento de serviços prestados em clínicas privadas) $e$ de convênios previdenciários, com suas conhecidas distorçōes, além de não basear-se em um programa com objetivos e metas definidos para um efetivo controle das doenças bucais, embora não impeça que o nivel local o faça. Assim, os recursos que deveriam ser aplicados em programas de saúde pública acabam sendo desviados para manter a atomizada rede de prestação de serviços existente.

\section{:: 8.2.7. Dentifrícios Fluoretados}

Uma célere expansão da fatia correspondente aos dentifricios fluoretados caracterizou o mercado brasileiro nos últimos anos. Em 1989, com a adição de flúor ao creme dental que detinha a maior parcela das vendas populares (Kolynos branco, com aproximadamente $3 / 5$ do mercado), cerca de $90 \%$ dos dentifricios nacionais passaram a conter flúor. 
A concentração de flúor tem se mantido em padrōes adequados nos cremes e pastas dentais ofertados no país(74), sendo provável que gradativamente os efeitos preventivos dos dentifrícios deverão fazer-se sentir entre os brasileiros, contribuindo com sua parcela para a redução dos indices de cárie dental. A qualidade destes produtos estão regulados por portaria especifica da área de vigilância sanitária do Ministério da Saúde(36).

Da mesma forma que em relação aos bochechos e às aplicações tópicas de flúor, a ingestắo inadvertida de dentifrícios fluoretados deve ser evitada. Não há comprovações sobre a relação entre 0 volume de dentifricio ingerido acidentalmente e 0 teor de fluorose dental em países industrializados(15.58), recomendando-se por precaução que os pais escovem os dentes dos filhos pequenos, os quais devem usar uma escova infantil com uma pequena quantidade de pasta, sendo educados a bochechar vigorosamente e a não engolir durante e após a escovação. Além disso, a dosagem deve limitar-se a $1000 \mathrm{ppm}$ de flúor $(75,194,197)$.

A contribuição desses dentifrícios para a redução da cárie dental nos países desenvolvidos tem sido referida de maneira sólida $(11,60,78,96,132,144,145,160,161,190,194)$.

\section{: 8.3. Programas Estaduais e Municipais}

Uma resenha analítica sobre o desenvolvimento dos serviços públicos de odontologia a cargo dos estados e municípios é uma tarefa que exigiria dedicação e recursos específicos para ser concretizada, seja pela sua dimensão, seja pela variedade de situações e de experiências existentes, o que certamente ultrapassa os limites deste trabalho.

Procura-se aqui, tão somente, fazer referência a algumas das principais iniciativas que caracterizaram as atividades odontológicas de saúde pública nesse âmbito, principalmente sob o ponto de vista da sua influência sobre o conjunto do setor.

A tradição maior está na criação de serviços odontológicos de livre demanda destinados a realizar extrações, atendimentos de urgencia e as vezes restauraçōes para uma clientela na qual predominam adultos de baixa renda.

Mas, já nos anos cinquenta começaram a desenvolver-se serviços de atenção a escolares de 12 grau em Secretarias de Educação e de Saúde. Alguns estados criaram abrangentes serviços de saúde escolar, como São Paulo, Rio Grande do Sul, Rio de Janeiro, Minas Gerais, Pará, Paraiba, Alagoas e Ceará. O Serviço Dentário Escolar da Secretaria de Educação do estado de São Paulo chegou a ser tido na década de 70 como o maior de todo o mundo devido ao número de odontólogos que empregava. O modelo básico de trabalho era o do "sistema incremental" popularizado pela Fundação SESP, que incluia três programas: um curativo, prevendo cobertura ascendente dos escolares por idade em geral a partir dos 6 ou 7 anos e manutenção das crianças tratadas; um preventivo que primeiro tentou aplicaçōes tópicas de fluoreto de sódio neutro a $28 \mathrm{com} 4$ cadeiras simultâneas 
e depois os bochechos semanais com NaF a 0,28 ; e um educativo, com aulas eventuais sobre higiene oral ou, em alguns casos, inclusão de ensinamentos no currículo escolar $(9,89,136,180,222)$.

$\mathrm{Na}$ prática, a maioria dos incrementais(203.226) e principalmente os de grande porte limitaram-se a organizar o afluxo de pacientes às clínicas, construindo uma razoável base curativa e algumas ações educativas, mas falhando em dois pontos essenciais. Primeiro, por não terem conseguido concretizar o seu objetivo maior, de reduzir a incidência de cáries, ao adotarem modelos preventivos de curto alcance e metodologicamente inadequados. Os bochechos semanais, p.ex., previam uma frequência regular e perene das crianças, numa época em que as interrupções das aulas e a deserção do alunado tornaram-se quase endêmicas inclusive no $1^{2}$ grau.

A segunda falha deu-se na cobertura populacional, que não cresceu ao contrário do que previa toda a teoria do Incremental, fundamentada no avanço gradativo idade por idade. Os programas mantiveram-se, com raras exceçōes, em torno de 15 a 258 do alunado, em geral como um efeito demonstração do que seria possível fazer. Profissionais de tempo parcial, o hábito de dedicar apenas 2 a 3 horas ao trabalho embora o contrato fosse de 4 horas diárias, a não contratação de pessoal auxiliar ou em alguns casos de novos odontólogos, a ausência de uma coordenação técnica firme (ainda hoje é comum nomear como coordenador de odontologia o "dentista do governador, do prefeito, do presidente", etc.) e as consequências de ações preventivas de baixa eficácia, foram razões, entre outras, que explicaram com distintos graus de importância, as dificuldades dos Incrementais tradicionais em realmente proteger um volume significativo de crianças.

Alguns programas devem ser destacados pela sua importância em si ou pela influência que exerceram em distintas épocas. No começo dos anos setenta, p.ex., a Secretaria de Saúde e Serviço Social da Prefeitura Municipal de Porto Alegre chegou a implantar um programa escolar que alcançou 148 de cobertura da matrícula no primeiro ano, 288 no segundo e 528 no terceiro, em 1973, sem aumento de quadro, tendo sido ainda pioneiro junto com a F.SESP na implantação dos bochechos fluoretados no pais.

Mais tarde, na segunda metade da década de setenta, surgiu o modelo de simplificação trazendo os principios da tecnologia apropriada para a odontologia(76.171). A base deste movimento foi dada pelo Programa Integrado de Saúde Escolar da Secretaria de Educação e pelo Serviço Social do Comércio, ambos do Distrito Federal, sendo o responsável entre outros avanços, pela introdução de equipamentos eficazes e de custo reduzido através da eliminação dos elementos supérfluos que caracterizavam os consultórios tradicionais. Foi também em Brasilia que o treinamento em serviço de atendentes e técnicos de higiene dental começou a ser feito, desenvolvendo-se as clínicas modulares com três ou mais "camas clinicas" (e não as costumeiras "cadeiras odontológicas") que hoje são comuns virtualmente em todos os estados. As clínicas modulares com seus equipamentos nāo sofisticados logo passaram a ser produzidos por diversas oficinas pertencentes tanto a instituições 
públicas como no caso da Secretaria de Saúde de Minas Gerais, como a artífices privados como no Paraná e São Paulo p.ex.(154,169,213).

o uso de pessoal de nível técnico e de equipamentos tecnologicamente adequados tornou possivel, em teoria, aumentar a produtividade e reduzir os custos tanto de implantação quanto de manutenção dos serviços odontológicos $(76,89,169,175,207,214,216,226)$.

- Serviço Social da Indústria adotou com maior intensidade esta linha, através do seu Programa Nacional de Odontologia Social que apoia financeiramente a implantação das clinicass coletivas, 0 treinamento e a contratação de THDs nos estados $(215,216)$.

Soluções inovadoras para viabilizar o atendimento de grupos populacionais normalmente sem acesso às clínicas urbanas tradicionais tem sido experimentadas, como no uso de equipamento simplificado transportável para prestação de serviços recuperadores a crianças e de emergência a adultos residentes em zona rural(170), e na prática do "circo de saúde", criado em Natal para atender inclusive a crianças em idade escolar não matriculadas na rede pública, em uma clínica instalada sob um vistoso toldo que se movimenta com relativa agilidade pelos bairros.

os estados de maior porte são também os que possuem os sistemas quantitativamente mais numerosos: São Paulo, Minas Geräis, Paraná, Rio Grande do Sul, Rio de Janeiro.

Com o advento do Sistema Único de Saúde(20,21,65,177,200), iniciouse uma gradativa municipalização com a passagem de unidades antes pertencentes aos estados e também do INAMPS para as prefeituras. Embora o Sus claramente favoreça a municipalização, este é um processo irregular no Brasil(79), que ainda depende do repasse de recursos que permanecem nas mãos do governo central (Ministério da Saúde/INAMPS) e de acordos políticos entre governos estaduais e municipais. Dentro desta tendência, diversos serviços municipais começaram de maneira mais efetiva a assumir a tarefa de dar saúde à população local. Os resultados, onde isto tem acontecido, costumam ser positivos, reforçando o conceito de que a odontologia é uma atividade essencialmente local, que por suas características de não sofisticação a nível de serviços básicos, desenvolve-se mais idealmente quando é programada, executada e avaliada a este nível.

No Paraná uma mescla de serviços estaduais e municipais emprega cerca de 408 dos odontólogos existentes no estado, além de um grande número de THDs e atendentes de consultório. Em algumas cidades paranaenses níveis elevados de cobertura de escolares e resultados preventivos positivos foram alcançados(169). Em Santa Catarina, um estado cujo modelo de desenvolvimento produziu uma maior consolidação do poder local, pode-se encontrar diversos servicos municipais de odontologia que desde o inicio tem como base de financiamento a própria cidade(153).

Em Uberlândia a Secretaria Municipal de Saúde cobriu $77 \%$ das crianças matriculadas no ensino constatar que apesar de conseguir a inversão dos

- que em 1990 elementar, ao componentes do 
índice CPO (dentes cariados em restaurados), a redução na incidência de cáries fora menor do que a esperada, optou por um programa preventivo em massa com base em aplicações tópicas de flúor $(9,226)$.

Uma reorientação na linha preventiva foi o fator que conduziu a Secretaria Municipal de Saúde de São José dos Campos (São Paulo) a desenvolver um programa de saúde pública modelar(203,207). Comparando-se os dados de 1979 e de 1991, houve uma redução real no CPO-D de 65\% aos 7 anos, de $48 \%$ aos 10 anos, de $51 \%$ aos 12 anos e de $40 \%$ aos 14 anos. O Gráfico X mostra a evolução do indice CPO-D nos escolares de 12 anos, mostrando que além da diminuição global do indice, os fatores " $\mathrm{E}$ " e " $\mathrm{E} i$ " virtualmente desapareceram. Além de ter uma extensa cobertura ( $88 \%$ dos alunos das escolas municipais e 678 das escolas estaduais, em 1990), a partir de 85 ao modelo preventivo usual constante de bochechos fluoretados semanais e educação em saúde bucal (ESB), foi acrescido um regime de cuidados especiais ãs crianças de alto risco, individualizando a ESB, fazendo aplicação tópica com gel flúor-fosfato acidulado e profilaxia duas vezes ao ano. Foram consideradas como de risco aqueles cujo CPO-D situava-se acima da média do seu grupo etário. 


\title{
GRÁFICO X
}

INDICES CPO-D E COMPONENTES EM ALUNOS DE 12 ANOS

\begin{abstract}
ESCOLAS MUNICIPAIS DE S.JOSÉ DOS CAMPOS-1979,85 e 91
\end{abstract}

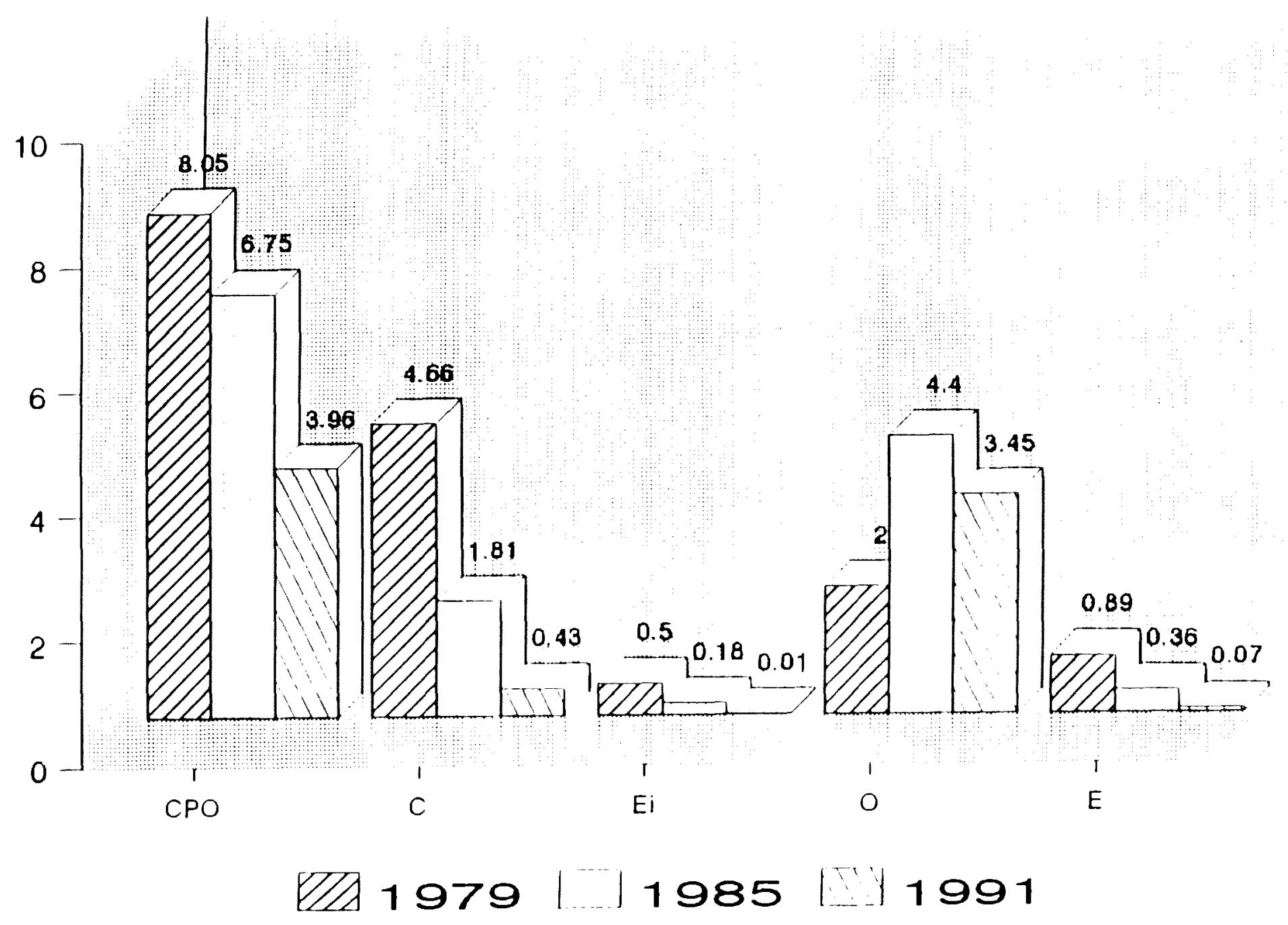




\section{: 8.4. Temas Relacionados}

Dois grandes temas têm direto relacionamento com o campo da saúde bucal e porisso são aqui tratados com maior interesse e em títulos separados: de um lado, o consumo e a produção de acúcar em função da dependência que a cárie dental apresenta para com os hidratos de carbono e, de outro lado, o sistema de ensino elementar brasileiro que concentra a maioria da clientela considerada prioritária para o atendimento odontológico.

\section{:: 8.4.1. Consumo e Produção de Açúcar}

Desde que Martin Afonso de Souza descobriu, em 1.531, as chamadas províncias açucareiras no nordeste brasileiro, este país não mais parou de plantar cana. Não é de surpreender que no século atual a cárie tenha se tornado em um dos grandes males a assolar a população: a produção nacional que era de aproximadamente um milhão de toneladas em 1938, passou para cinco milhões em 1970, e a mais de 9,5 milhões em 1983 em marca até hoje não ultrapassada $(4,5,181)$.

As relaçōes de causa e efeito que unem o consumo de açúcar e a ocorrência de cáries dentais estão amplamente comprovadas $(60,78,99,144,160)$.

$\mathrm{Na}$ verdade, O Brasil situa-se entre os cinco maiores produtores mundiais de açúcar, tendo respondido por quase 78 do total em 1989. Individualmente, nesse ano, somente a India, a Comunidade de Estados Independentes e Cuba superaram a cota brasileira $(83,126,178,225)$.

- país possui a mais ampla área colhida de cana de açúcar de todo o mundo, com 4,1 milhōes de hectares em 1988. Também a nossa produção de cana supera largamente à dos demais países (259 milhões de toneladas nesse ano - a India, em segundo lugar obteve 197 milhões). Contudo, a produtividade da lavoura de cana brasileira é baixa. De acordo com dados da FAO(83) o rendimento médio nacional, de $62.623 \mathrm{~kg} / \mathrm{Ha}$, ainda que supere ligeiramente a média mundial que é de $60.400 \mathrm{~kg} / \mathrm{Ha}$, mostra-se inferior a pelo menos trinta outras nações, incluindo diversas do continente africano de menor tradição no mercado.

- estado de São Paulo é responsável por 438 da área colhida e por $52 \%$ da produção de cana de açúcar, estando o restante atomizado principalmente nos estados de Pernambuco, Alagoas, M.Gerais, Rio de Janeiro, Paraná e Paraiba(4,5).

o aproveitamento da cana colhida tem sofrido fortes modificações, particularmente na década de oitenta quando a tradicional quase que exclusividade do açúcar cada vez mais cedeu 0 passo para a crescente fabricação de álcool. As razões para a oscilação no volume de açúcar produzido, no caso brasileiro, devemse fundamentalmente à participação do álcool e aos preços internacionais do produto. Neste último decênio, p.ex., os preços internacionais do açúcar variaram entre a mais baixa cotação de 81 libras esterlinas em 1.985 até a mais alta, de 196 libras em 1.989 
quando atingiu a um auge a recuperação da competitividade financeira do setor(126), justificando em boa parte 0 redirecionamento do aproveitamento da cana para 0 açúcar e as críticas ao programa de apoio ao álcool como combustível que se fizeram sentir em 1990 e 91.

A produção de açúcar, o total exportado e consumido, assim como o consumo per capita para o periodo 1980/89 está na Tabela 39. Observa-se que nos últimos dois anos da série houve uma diminuição no volume global deste produto, atingindo um ponto inferior ao do começo da década(126,225). Possivelmente isto não caracteriza uma tendếncia de redução, e sim uma resposta às quedas de preços internacionais que vinham se verificando.

A maioria do açúcar produzido é consumido. Nos últimos cinco anos (85/89), o Brasil produziu 40,9 milhões de toneladas de açúcar e exportou $1 / 4$ (10,1 milhōes ton), consumindo internamente os $3 / 4$ restantes (para fechar estes números, considerar um estoque de 4,45 milhões de toneladas ao final de 84)(126).

- consumo per capita medido desta forma, ou seja, o total de açúcar disponivel no país dividido pela população, não corresponde ao que de fato é ingerido por parte de cada um, superestimando este último dado. Não obstante, trata-se de um indicador importante pois permite observar possíveis variações globais e principalmente as tendências na disponibilidade interna de açúcar(78,181,190). A média geral, em torno de 129 gramas por pessoa/dia, mostra que a tendência não é de um menor consumo, acontecendo somente desniveis circunstanciais. Não se dispōe de um padrão que indique que disponibilidade geral de açúcar em um pais é compatível com indices aceitáveis de cáries em crianças e adolescentes(99.180). Estudos genéricos de sreebny(224) com base na disponibilidade de açúcar indicam 50 gramas/dia como satisfatório, o que parece compativel com as quantidades médias de consumo apresentadas pelos países, principalmente da África e Ásia, nos quais os niveis de prevalência de cárie dental em crianças de 12 anos de idade são muito baixos. Se aplicarmos o padrão de $50 \mathrm{~g}$ ao caso brasileiro, teremos um consumo exagerado de aproximadamente 79 gramas/dia, 0 que certamente é mais do que suficiente para justificar os altos índices de cáries prevalentes na população de todas as idades.

$\mathrm{Na}$ Pesquisa de Orçamentos Familiares $1987 / 88$ realizada pela Fundação IBGE(107), o "consumo alimentar domiciliar per capita diário" observado foi de 70,75 gramas de "açúcares e produtos de confeitaria", 0 que inclui os açúcares em si (cristal, demerara, refinado e ádoçantes), mais os doces e derivados. E provável que este número seja um pouco maior, pois nos dados do IBGE devem ser acrescentados alguns poucos produtos que utilizam açúcar na sua elaboração - laticínios: creme de leite; leite achocolatado, com sabor e condensado - que no conjunto significam mais 3,35 gramas/dia, elevando o total para cerca de 74,10 gramas/dia. Isto significa uma ingestão equivalente a pouco mais de $578 \mathrm{da}$ disponibilidade global de açúcar estimada em $129 \mathrm{~g}$. 
uuando examinamos as quantidades consumidas por produto, vemos que a maior parte refere-se ao açúcar refinado $(42,8$ gramas) e ao açúcar cristal $(18,5$ gramas). Os doces, derivados e outros produtos significam apenas 9,41 gramas/dia por pessoa. Os adoçantes, sejam êles artificiais ou naturais concentrados, participam com apenas 0,043 gramas/dia ou pouco mais de meio por cento da ingesta total.

Vale notar, ainda, que há variações regionais que pelo menos em dois casos são significativas quanto à ingestão de açúcares, doces e derivados: a média global de 70,75 gramas/dia traduz um equilibrio de situaçōes díspares como as de Belém $(44,22 \mathrm{~g})$ e Belo Horizonte $(94,05 \mathrm{~g})$. Recife, Salvador, Fortaleza, Goiânia, São Paulo e a já citada Belém situam-se abaixo da média geral, ao passo que além da capital mineira, Rio de Janeiro, Curitiba, Porto Alegre e Brasilia a superam. Em princípio, os niveis de ingestāo no norte e nordeste parecem ser inferiores aos das demais regiōes.

Esta última constatação se vê confirmada pela análise da estrutura das despesas em alimentação no domicílio das onze capitais integradas à Pesquisa de Orçamentos Familiares. Os açúcares em geral tem a significativa representatividade média de 4,458 sobre os gastos alimentares das familias, sendo que comparativamente os gastos sāo sempre menores em Belém (2,97\%), Salvador (3,398), Recife $(3,948$ e Fortaleza (4,088). Os maiores padrões de despesas com açúcares pertencem às famílias de Curitiba $(8,898)$, Porto Alegre $(5,328)$ e Belo Horizonte $(5,30 \%)$. Sistematicamente os grupos de baixa renda gastam relativamente mais na aquisição de açúcares e derivados do que os de alta renda. Em curitiba, por exemplo, as familias que ganham até dois saláriosmínimos despendem 88 de seus orçamentos para alimentação com açúcares, ao passo que as que recebem 30 salários ou mais destinam 4,58 a esta mesma finalidade(107).

Nos últimos anos começou a ganhar destaque e a chamar a atenção dos profissionais de saúde pública uma linha de alimentaçāo alternativa que procura recuperar crianças desnutridas e atuar como um fator de equilibrio alimentar também para adultos, baseada no fornecimento de micro-nutrientes ao organismo notadamente através da ingestão de farelo de arroz ou de trigo(17). Este modelo também faz uso de verduras e de partes alternativas de frutos e legumes, obtendo resultados nutricionais positivos a custos muito mais baixos que os da alimentação "de supermercado". Como nas dietas adotadas há uma ativa redução no consumo de hidratos de carbono cariogênicos e um acréscimo de fibras que favorecem a mastigação, 0 ambiente bucal torna-se menos propício ao desenvolvimento de cáries.

A elevada ingesta de hidratos de carbono funciona no caso brasileiro, principalmente no que se refere às camadas mais pobres, como o meio mais barato para fornecer as calorias necessárias e repor energias perdidas(180), diante do alto custo dos alimentos a base de proteinas que costumam ser financeiramente inacessíveis. As razôes econômicas que cercam o consumo de açúcar junto com as características do processo de produção e comercialização dos derivados da cana, constituem-se nas variáveis principais que 
precisam ser conhecidas e aprofundadas pela profissão odontológica, considerando que a principal das doenças bucais, a cárie dental, é açúcar-dependente. 
TABELA 39

PRODUÇÃO. EXPORTACAOO, ESTOQUES E

CONSUMO DE ACCÚCAR NO BRASIL.

\begin{tabular}{|c|c|c|c|c|c|}
\hline$\overline{\text { ANO }}$ & {$\left[\begin{array}{r}\text { PRODUCAOO } \\
(\mathrm{mil} T)\end{array}\right.$} & $\begin{array}{l}\text { EXPOAT. } \\
(\mathrm{mil} n\end{array}$ & $\begin{array}{l}\text { CONSUMO } \\
\text { (mil } \mathrm{T})\end{array}$ & $\begin{array}{c}\text { ESTOOUE } \\
\text { (mil } \mathrm{T})\end{array}$ & $\begin{array}{r}\text { CONSUMO } \\
\text { PER CAPITA } \\
\text { (gramas/dia) }\end{array}$ \\
\hline 1,982 & 8,940 & 2,788 & 6,097 & 3,590 & 134 \\
\hline 1,983 & 9,555 & 2,801 & 5,908 & 4,446 & 125 \\
\hline 1,984 & 9,259 & 3,039 & 6,201 & 4,454 & 129 \\
\hline 1,985 & 8,455 & 2,609 & 6,080 & 4,221 & 123 \\
\hline 1,986 & 7.999 & 2,554 & 6,589 & 3,077 & 130 \\
\hline 1.987 & 9,266 & 2,424 & 6,572 & 3,346 & 127 \\
\hline 1.988 & 7,874 & 1,610 & 6,241 & 3.369 & 118 \\
\hline 1.989 & 7.326 & 965 & 7,401 & 2,328 & 137 \\
\hline
\end{tabular}

Fonte: Bibliogratia 126. 


\section{:: 8.4.2. Sistema de Ensino Elementar}

Do ponto de vista epidemiológico, as crianças em idade escolar primária, fundamentalmente entre 6 e 14 anos, constituem o grupo de maior prioridade em função do aparecimento da dentição permanente e dos padrões de ataque pela cárie dental que se verificam neste período. Os dados apresentados na Tabela 23 mostram que a doença comporta-se de maneira mais agressiva até a adolescênciá, diminuindo de intensidade na fase adulta que coincide com a maturidade dos tecidos dentários.

m consequência, o atendimento odontológico tem se dirigido predominantemente para este grupo, numa tentativa de bloquear a cadeia epidemiológica, ou através da prevenção ou proporcionando tratamento nas fases iniciais da doença de modo a impedir o seu agravamento e evitar os gastos bem maiores que se fariam necessários para conter lesões mais complexas(229). Todos os países que possuem sistemas de atenção odontológica bem estruturados e com elevados niveis de cobertura populacional partiram do atendimento adequado às crianças em idade escolar primária, daí evoluindo gradativamente para os adolescentes, infantes e depois aos adultos. Ainda hoje, países como o Reino Unido, a Suécia, a Finlândia, a Nova Zelândia ou a Austrália, p.ex., mantém sistemas que asseguram acesso integral aos serviços odontológicos por parte de crianças $e$ adolescentes, deixando a saúde bucal dos adultos por conta de regimes de financiamento pessoal ou via seguro-saúde(181).

No Brasil, os serviços públicos adotaram o "sistema incremental", que previa uma cobertura gradual e ascendente a partir das idades menores. A lógica deste sistema radica-se no fato epidemiológico de que a prevalência de cárie em dentes permanentes é menor nas idades mais baixas, constituindo-se portanto no momento ideal para intervir com ações preventivas, educativas e curativas.

Conforme já se comentou no Título anterior, os resultados desse sistema em geral foram insatisfatórios. Só em parte o insucesso pode ser explicado pela adoção de métodos preventivos inadequados, pela baixa produtividade e pelo hábito de não cumprimento pelos profissionais dos horários contratados. Ao que tudo indica, boa parte das dificuldades que enfrentam ainda hoje os modelos de atendimento odontológico escolar situam-se no próprio sistema de ensino elementar (1 à à $8 \mathbf{a}$ série do 19 grau), que funciona de maneira inconstante $e$ com baixos níveis de aproveitamento.

Os programas escolares de saúde bucal(229) pressupõem, costumeiramente, uma regularidade na presença dos alunos nas escolas que na prática não existe. Considerando o fato de que no Brasil a grande maioria das crianças de 7 a 14 anos está matriculada na rede de ensino de 10 . grau, parece essencial que 0 setor odontológico compreenda a lógica -ou a falta de-(GUSSO) (98) com que funciona o sistema escolar, a fim de a êle adequar-se.

De acordo com os dados oficiais, a taxa de escolarização cresceu continuamente durante a década de oitenta, de tal forma 
que, em 1989, 48\% das crianças de 5 e 6 anos, 858 entre 7 e 9 anos, 83 entre 10 e 14 anos e 55\% entre 15 e 17 anos estavam matriculadas(22,23,29). Considerando a população de 7 a 14 anos e uma escolarização de 84,58 , tinhamos em 1989 um total estimado de 4,4 milhões de crianças fora da escola, para 24 milhões matriculadas(26,73). O contingente de alunos não escolarizados manteve-se aproximadamente igual no decênio, com um máximo de 5,3 milhões em 79, um mínimo de 3,4 milhões em 83 e uma média anual em torno de 4,3 milhões $(28,73)$.

A elevada taxa de escolarização esconde a precariedade do sistema de ensino elementar brasileiro. O fato de que a maioria das crianças esteja matriculada não significa que elas de fato estejam nas escolas.

No destaque abaixo temos um conjunto de indicadores de eficiência do ensino fundamental (primeiras oito séries) para a década de $80(157,158)$.

\section{QUADRO 6}

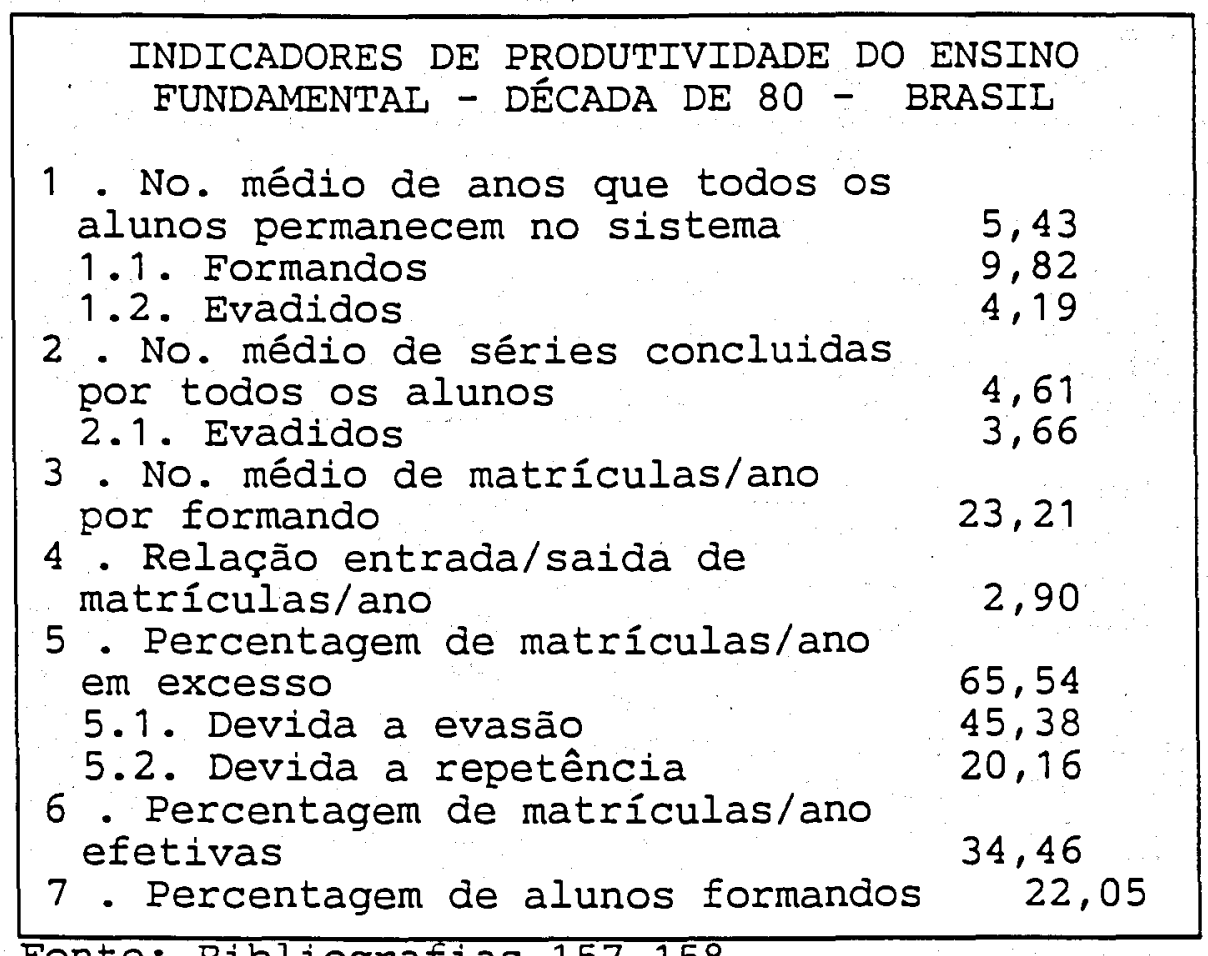

Se combinarmos os indicadores 1 e 7 , podemos concluir que os 228 que, em um coorte, conseguem formar-se, permanecem em média quase dez anos no sistema ao invéz das oito séries que perfazem o ciclo completo. Os demais $78 \%$ permanecem pouco mais de 4 anos na escola. No total, cada criança brasileira fica 5,4 anos nas escolas de ensino elementar. Para cada aluno que consegue terminar 010. grau são necessárias 23,2 matrículas.

Parece difícil compatibilizar os dados de matrícula total com os de evasão. A evasão aqui representada é a imediata, ou seja, a 
que ocorre num mesmo ano (crianças presentes no começo do ano e não matriculadas em dezembro). Na prática, as crianças saem da escola em épocas variadas ao longo do ano para tornar a matricular-se em algum ano seguinte, ou seja, entram e saem do sistema, mas a cada vez que entram aparecem nas estatisticas inflando as taxas de matrícula.

Acrescente-se à nossa equação, portanto, que os 5,4 anos na escola podem não ser contínuos e em muitos casos podem representar um tempo curto de permanência efetiva.

Segundo Gusso(97), "conforme o grau de lotação do prédio escolar, as turmas podem ser compostas por cerca de 25 até cerca de 45 alunos; em casos de superlotação, além de turmas mais numerosas, funcionam também vários turnos escolares, no período diurno, reduzindo-se a duraçăo de cada turno. Calcula-se que, nas cidades, onde é típica esta situação, haja 6,5 milhões de alunos em escolas com mais de dois turnos, o que significa que eles ficam, em média, 3 horas/dia sob atenção escolar, obrigando os docentes a acelerar as atividades de ensino".

De qualquer maneira, até aos 9 anos as crianças podem ser encontradas nas escolas. É óbvio que, se o sistema de prestação de cuidados odontológicos desejar de fato trata-las, deverá identificar localmente quais os periodos do ano e do dia em que a frequência é mais efetiva, adaptando a sua dinâmica à das escolas da região.

o problema aumenta a partir dos 10 anos, quando cada vez um maior contingente ingressa no mercado de trabalho, estimando-se que na zona urbana cerca de 12,28 (1,4 milhão em 1989) do grupo de 10 a 14 anos já possua alguma atividade econômica(73,130).

Em todos os casos o sistema de ensino é fortemente discriminatório quanto à renda das familias e, em consequência, da regiāo de residência. Os mais pobres ingressam mais tardiamente no sistema, demoram mais a formar-se, evadem mais, etc. Um exemplo das diferenças regionais pode ser visto no Gráfico XI, que compara crianças de 10 a 17 anos do nordeste e do sudeste segundo a atividade que exercem. No primeiro caso 128 trabalham e estudam e outros $11 \%$ só trabalham, ao passo que no segundo caso estas proporçōes são de 8 e $7 \%$, ainda altas mas comparativamente melhores ${ }^{(73)}$.

As escolas rurais, que apresentam menores indices de evasão, em sua quase totalidade limitam-se a ofertar as quatro primeiras séries. Na quinta série, que corresponde à 1a. série do antigo curso ginasial (a separaçao entre primário e ginásio permanece nítida no sistema educacional do país), os alunos que desejam prosseguir seus estudos migram para as cidades.

Finalmente, cabe constatar o predomínio das escolas públicas no âmbito do ensino elementar: na zona urbana, onde a concorrência das escolas privadas é maior elas representam apenas 20,7\% dos estabelecimentos e 15,5\% das matrículas. As escolas estaduais, não 
obstante em teoria o sistema deva ser municipal, representam 53\% do total reunindo $2 / 3$ dos alunos $(28,29)$. 


\section{GRÁFICO XI}

PESSOAS DE 10 A 14 E DE 15 A 17 ANOS, SEGUNDO A ATIVIDADE EXERCIDA

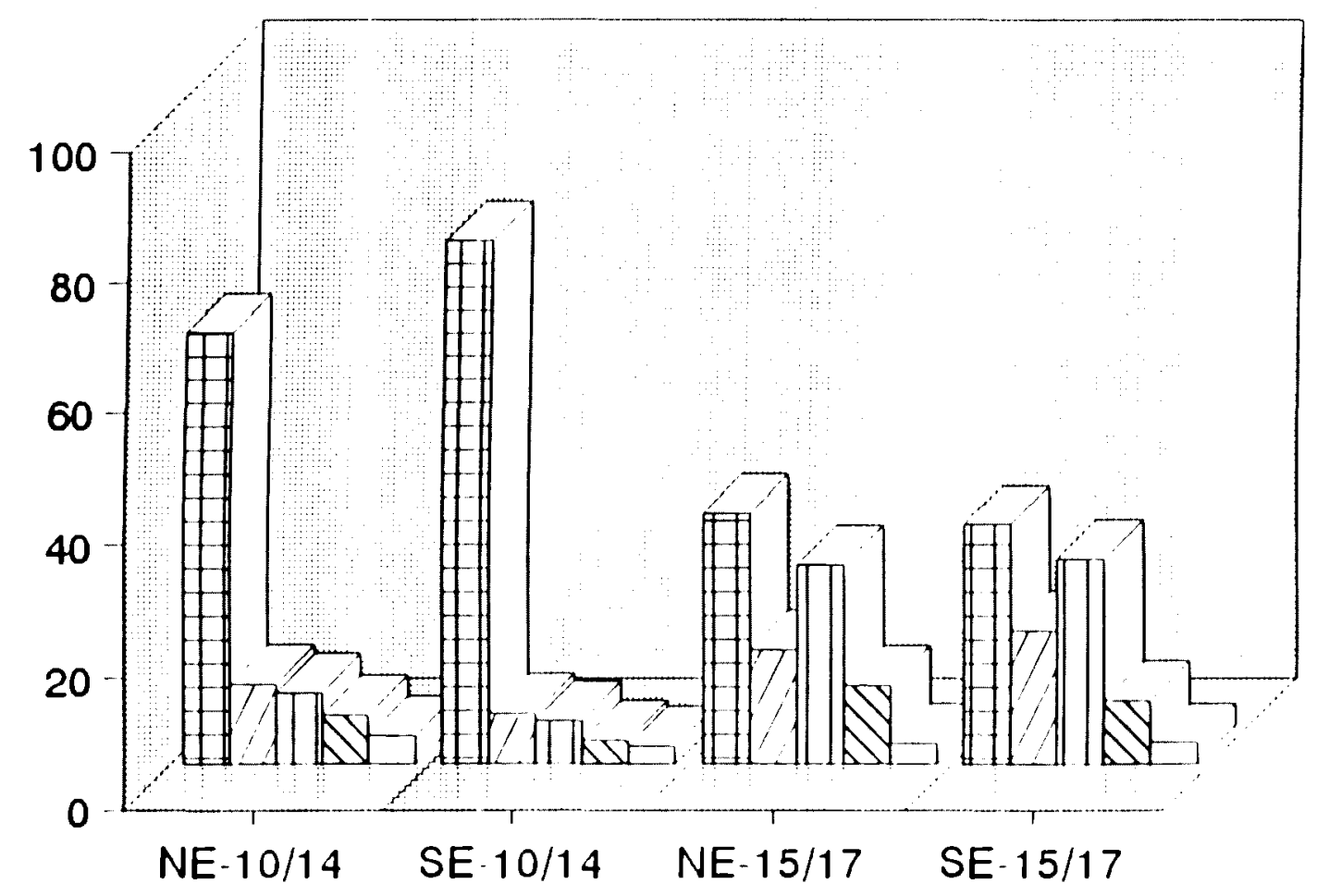

ESSO ESTUDA

I]TRAB. ESTUDA

III SO TRABALHA

DAFAZERES DOM.

IINADA

\begin{tabular}{|c|c|c|c|c|}
\hline SO ESTUDA & 65 & 79 & 38 & 36 \\
\hline TRAB ESTUDA & 12 & 8 & 17 & 20 \\
\hline SO TRABALHA & 11 & 7 & 30 & 31 \\
\hline AFAZERES DOM & 7 & 4 & 12 & 10 \\
\hline NADA & 4 & 3 & 3 & 3 \\
\hline
\end{tabular}


: 8.5. Compatibilidade entre o Sistema Prestador de Serviços e os Quadros Epidemıolóaico e Social

Uma vista panorâmica sobre as múltiplas variáveis envolvidas no processo saúde/doença na área odontológica revela uma escassa compatibilidade entre o aparato de prestaçāo de serviços construido ao longo deste século e as condições de saúde bucal da população brasileira.

Esta inadequação, embora toda a sua ilógica, não é típica do Brasil. Ao contrário, parece ser uma característica da própria profissão a nivel internacional. Ao examinar o tema do "relacionamento entre padrōes de doença e serviços de atenção odontológica" na Conferência Odontológica Mundial realizada em 1988 na cidade inglêsa de Bristol, o autor(78.178)referiu com base nos dados da oMS e da FDI, entre outros pontos, que as grandes concentraçōes de Cirurgiōes-Dentistas no mundo estavam exatamente nas regiōes (América Latina e Paises Industrializados) com os mais altos índices de ataque pela cárie dental. Na África e Ásia, com um CPO médio aos 12 anos de 2,19 dentes - o menor do Glogo - havia $36,9 \mathrm{mil}$ pessoas por odontólogo, ao passo que na América do Sul o indice era de 5,73 e a relação de 1.745 pessoas por profissional, neste último sentido quase igual à da Europa Ocidental. Outros fatores, como o nível sócio-econômico, condições culturais, hábitos alimentares como o consumo de açúcares e o grau de desenvolvimento global de cada país pareciam exercer uma influência bem maior do que o aparelho prestador de serviços odontológicos sobre o nível de saúde de cada comunidade.

No caso brasileiro, é inegável que a profissāo cresceu ao ponto de reunir mais de cem mil profissionais e movimentar em torno de 2,4 milhōes de dólares ao ano (Tabelas 9 e 21), mas isto não se mostrou suficiente para que a população alcançasse níveis razoáveis de saúde oral. Ao contrário, o país manteve-se sistematicamente classificado entre os piores índices de ataque pela cárie dental em toda a última década.

Ao que tudo indica, a profissão seguiu uma rota enquanto o quadro epidemiológico e as condiçōes de vida seguiram uma outra, distinta e não paralela. Uma das consequências é que os serviços ofertados permanecem acessíveis somente a uma pequena parcela da nação.

Acima de tudo está o modelo de desenvolvimento econômico capitalista seguido pelo país - do qual a prática odontológica é um fiel exemplo - que deixa largas camadas da população sem acesso até mesmo ao limitado mercado de bens e serviços básicos, como vimos em detalhes no Título 4.2. Sem dispor de renda sequer para atender as mais prementes necessidades de alimentação, moradia e roupa da familia, muitos brasileiros não têm como obter serviços odontológicos que em sua maior parte são livremente oferecidos no mercado, estando disponíveis apenas para quem puder paga-los.

Os profissionais disponíveis, em grande número, concentram-se predominantemente nas áreas mais ricas. O sul e o sudeste, que 
reunem 608 da população, contam com 778 dos odontólogos; no nordeste estão $28 \%$ dos habitantes e 148 dos odontólogos (Tabela 9).

Apesar da continuada crise econômica nacional, a odontologia atrai um crescente número de candidatos(Tabelas 10 a 12), mas isto ocorre nâo porque haja necessidade de um maior número de profissionais para diminuir os altos índices de doenças bucais prevalentes, e sim porque esta é efetivamente uma das últimas profissões mais tipicamente enquadradas como liberais.

Há um "não-sistema" de atenção odontológica no país, com uma grande pulverização em termos de instituições prestadoras de serviços e sem um programa global que oriente as entidades locais quanto às linhas mais corretas a seguir. Os 40.567 postos de trabalho existentes em 1989 no setor público e para-oficial (Tabelas 13 e 15) representam sem dúvida uma força muito significativa e poderosa por seu elevado número, mas apesar disto este setor tem sido incapaz de garantir serviços básicos e de reduzir os níveis de doenças bucais, tal é a sua desarticulação e falta de unidade.

Vários municípios e alguns estados ou entidades possuem bons programas que podem servir de exemplo aos demais, acreditando-se que em breve começarão a aparecer os efeitos preventivos da recente expansāo do método de fluoretação da água e dos dentifrícios fluoretados. As esperanças de que isto de fato ocorra passa, em boa parte, pela opção necessária para o país de que o setor saúde mantenha o seu carater social, fugindo das duras regras de competição generalizada do sistema capitalista. Caso este caminho seja seguido, teremos um fortalecimento dos serviços públicos para que, dentro das regras vigentes, tenham condiçōes de melhor competir com a iniciativa privada.

A distribuição dos recursos gastos em odontologia não pode ser tida como por demais perversa. Afinal, em um país nitidamente capitalista, o setor público responde por 308 dos dispêndios (Tabela 21). Isto indica, em princípio, que se justifica um esforço sério de reorganização deste setor, fornecendo-lhe um programa de ação e reduzindo de maneira significativa problemas típicos como o não cumprimento do horário contratado, a dupla militância (desvio de pacientes para a clínica privada ou menor eficiência no trabalho realizado nas clínicas governamentais) e os baixos salários.

A participação da população junto aos serviços odontológicos ainda é reduzida, concentrando-se nos programas (em São Paulo e Paraná, a nível municipal há bons exemplos nesse sentido) que buscam interagir com os setores mais organizados da comunidade. 


\section{RESPOSTAS DO SISTEMA PRESTADOR DE SERVIÇOS: SUGESTÕES}

- conjunto de sugestões aqui apresentado visa fornecer um guia geral para que cada profissional ou cada serviço melhor se oriente em seu dia-a-dia.

Não se trata de um programa de trabalho, e sim de diretrizes para a ação. O programa deve ser elaborado por parte de cada estado, de cada município e, principalmente, de cada serviço pois é ao nivel local que as ações precisam concretizar-se, solucionar os problemas existentes e proporcionar satisfação tanto à comunidade que requer os serviços quanto aos profissionais que os executam.

Em um país com tantos problemas sociais e econômicos, a luta política de nenhuma maneira pode ser considerada como um elemento secundário na política setorial. É preciso compreender que não é possível construir um setor ideal dentro de uma sociedade corroida por dificuldades de toda ordem. A atuação setorial inclui, portanto, a ação política mais ampla, buscando criar as condições propicias para que as questôes específicas possam ser resolvidas. Isto não significa que as questões especificas devam ser abandonadas, quedando-se à espera de que o país melhore para que então possam ser tratadas idealmente. Significa, isto sim, que no atual momento vivido pela sociedade brasileira, é preciso atuar nos dois campos: cuidar dos problemas típicos da própria área profissional e ao mesmo tempo agir e influenciar no campo geral.

As diretrizes são de saúde pública, o que implica em dizer que as estratégias utilizadas têm abrangência populacional, são coletivas, buscando alcançar cada comunidade em seu conjunto.

Para um trabalho bem estruturado, que de fato tenha como finalidade a melhoria das condiçōes de vida e dos niveis de saúde bucal da população, é necessário que cada serviço defina com a maior clareza possível seus objetivos e metas a atingir tanto no curto prazo quanto para o futuro próximo. A adoção de objetivos e metas para o Ano 2.000 pode ser útil como um horizonte a perseguir e que, de qualquer maneira, já está bem à vista de todos. As ações de curto prazo e as programações para cada período de governo são naturalmente mais flexíveis e vão sendo modificadas à medida em que os desejos vão sendo satisfeitos.

Ao elaborar estes planos duas questões aparentemente elementares não podem ser esquecidas: em primeiro lugar, os resultados de médio ou mais largo prazo somente serão alcançados se agirmos sobre a realidade a partir de hoje e em cada dia de maneira distinta da atual, ou seja, modificando nossa prática para que gradativamente toda a situação mude; em segundo lugar. os planos e os objetivos devem adaptar-se 0 mais estreitamente possivel às características do meio em que irão desenvolver-se, reconhecendo que 0 meio é resistente aos câmbios e que qualquer estratégia a ser implementada terá que suplantar as tradições e as forças que sustentam os êrros e os problemas vigentes. 
Inicialmente há uma definição do sistema geral de atendimento, com fundamento na organização local do trabalho de saúde em geral e de odontologia em específico. Alguns pontos relevantes são destacados nessa discussão, enfocando questões sobre os limites dos sistemas locais, sua resolutividade, a população abrangida, a necessidade de administrar por objetivos $e$ as formas de participação social.

A partir desta base são aprofundadas as questões especificas de maior importância, através de um modelo de intervenção na realidade fundamentado na implementação de um conjunto de medidas essenciais e outro de medidas complementares, procurando desta forma orientar principalmente aos que tem em suas mãos a árdua tarefa de efetivamente fazer saúde para uma comunidade. Este modelo genérico está exposto no Título 9.2. Em seguida, nos Títulos 9.2.1 a 9.2.6 desenvolve-se uma análise mais detalhada das medidas essenciais e complementares propostas, o que envolve desde as diretrizes para organizaçāo de serviços dirigidos a crianças e adolescentes até as formas de integração ao Sistema Único de Saúde, passando pelas sugestöes relativas às atividades preventivas e educativas, aos sub-sistemas de vigilância epidemiológica e sanitária. Os Títulos finais trazem à baila componentes universais da política setorial: a preparação de recursos humanos (9.3), 0 custeio e as formas de remuneração (9.4) e finalmente, em 9.5, as sugestōes sobre as linhas de estudos e pesquisas mais necessárias.

\section{:9.1. Sistema Geral de Atendimento}

A odontologia brasileira tem pela frente duas grandes tarefas a executar no curto e no médio prazo: (a) reduzir a incidência do mais universal problema de saúde bucal, a cárie dental, a limites epidemiológicamente aceitáveis, e (b) estruturar uma rede de atendimento para prestar serviços básicos em quantidade suficiente e com boa qualidade à populaçāo.

Os caminhos para concretiza-las passam necessariamente pela quebra do individualismo e do isolamento da prática odontológica, através da sua efetiva integração à rede geral do Sistema único de Saúde-SUS.

Desde logo, é preciso frisar o caráter fortemente prioritário que no atual estágio de desenvolvimento econômico e social brasileiro possui o fortalecimento da rede e dos serviços públicos. A privatização da saúde, traduzida no subsídio a prestadores particulares de serviços com recursos de toda a sociedade, nāo encontra justificativa num quadro de crise vivido pela nação.

A integração das unidades de atenção odontológica ao sus tem como base metodológica o sistema de organização lo:al do setor. Os fundamentos desse sistema, sua abrangência, a clientela, suas metas e objetivos são discutidos a seguir. 


\section{:: $\quad 9.1 .1$. A Organização Local}

A descentralização dos serviços forma, junto com a universalização, a integração e a equidade, 0 conjunto de princípios que rege a política setorial. Consagra, principalmente a partir da Lei 8080(20), os sistemas locais de saúde (SILOS, na denominação utilizada pela OPS na América Latina) $(166,167)$, tendo criado as condições iniciais para o movimento de municipalização que desde então cresceu e fortaleceu-se em todo o país.

Um sistema local de saúde não deve ser confundido com uma unidade simples de atendimento ou com o nível primário de atenção. $\mathrm{Na}$ verdade, é toda uma rede articulada que inclui os recursos, serviços, instituiçōes e a comunidade, estruturada para dar um atendimento adequado a todos os problemas relevantes de saúde existentes numa determinada área geográfica e social.

A saúde bucal constitui um sub-sistema dentro de um SILOS, seguindo portanto os limites e diretrizes gerais mas conservando suas caracteristicas próprias.

É imprescindivel, para que a organização local se concretize e alcance seus objetivos, a definição da abrangência em termos geográficos, populacionais e de serviços a prestar. Numa tentativa de síntese, pode-se dizer que deve abarcar toda a população e todos os problemas de uma região homogênea. Esta região pode ser um município, um conjunto de municípios ou, em cidades maiores, um bairro ou um distrito. O melhor é que coincida com as divisōes administrativas já existentes, de modo a evitar as dificuldades que fatalmente surgiriam caso fosse criada uma malha especifica somente para o setor saúde. As distâncias geográficas não são 0 condicionante principal, e sim o tempo e as facilidades necessários para que um paciente receba atendimento compatível com a complexidade do seu caso, mesmo quando correr risco de vida ou de ficar incapacitado. Para melhor estabelecer os limites comumente são levados em consideração fatores como a acessibilidade, os transportes e as comunicaçōes, a capacidade resolutiva da rede, além das opiniões e costumes da população.

- sistema local considera a totalidade dos residentes na sua área de abrangência. Nem todos serão igualmente atendidos ou receberão idêntico tratamento, mas com base na identificação dos serviços (públicos, privados, semi-oficiais, previdenciários, beneficentes) disponiveis e dos problemas de saúde oral prevalentes, é estabelecido um programa de cobertura estratificado por grupos e por danos conforme o esquema sugerido no Título 9.2.

\section{:: 9.1.2. Adscrição da Clientela}

A adscrição da clientela surge nesse contexto como um conceito de grande importância estratégica e prática. A unidade deve reconhecer na comunidade local a sua comunidade, a sua clientela, ao passo que esta deve considera-la como a sua unidade, os seus serviços. A adscrição pode ser feita por unidade, por profissional ou por equipe de saúde; além disso pode ser identificada aos 
individuos ou às familias ou por grupos (crianças, adolescentes, trabalhadores, deficientes, idosos, etc.). Varia na dependência dos recursos disponiveis, do potencial resolutivo da rede, da acessibilidade geográfica, entre outros fatores, não devendo ser rígida mormente no começo quando as pessoas muitas vezes costumam manter seus costumes ou simplesmente procuram as unidades que tradicionalmente prestam os melhores serviços ainda que tenham localizção mais distante. Como são diversas unidades que compõem o sistema local, cada uma precisa ter a sua clientela adscrita de acordo com os serviços que presta; uma unidade básica terá um alcance mais restrito, ao passo que uma de referência, que presta serviços especializados para uma demanda dirigida e proveniente da rede básica, obviamente compreenderá um universo populacional mais amplo(166).

- sub-sistema odontológico, da mesma maneira que no âmbito da saúde geral, não tem a pretensão de resolver todos os problemas, mesmo porque sabidamente os grandes condicionantes das doenças orais localizam-se fora da sua área de influência. Acrescente-se que poucos SILOS terão capacidade para equacionar todas as situações e demandas da população que deles depende. A situação mais comum é de que uma série de problemas, de modo particular os mais complexos, só poderão ser equacionados em outras cidades, havendo assim uma forte necessidade de que as diversas organizaçōes locais estejam bem relacionadas.

A ênfase nos serviços locais - que encontra um ambiente ideal para concretizar-se na área odontológica - implica, embora isto possa parecer paradoxal à primeira vista, numa necessidade de reforço e de consolidação dos níveis regional/estadual e nacional, os quais jogam um papel fundamental (inclusive por estarem livres da prestação direta de serviços) de articulação, apoio financeiro, estabelecimento de intercomunicaçōes e de parâmetros e diretrizes gerais, assegurando o fluxo de pacientes, a execução de programas globais e eventualmente de serviços mais complexos. o plano nacional e o plano estadual de saúde bucal são fundamentais para dar unidade ao sistema e para balizar o trabalho a cargo das organizações locais.

A coordenação do sistema deve ser una, cabendo ao setor público normalmente através da Secretaria Municipal de Saúde. Em municípios pequenos ou sem estrutura específica, por vezes é necessário que a Secretaria estadual de saúde ou organismo de porte regional similar, assuma a coordenação e até mesmo a execução dos serviços, mas esta deve ser uma situação temporária que em um tempo definido precisa ser substituida por estruturas locais autônomas.

Contornar as dificuldades administrativas e as disputas entre as muitas entidades que usualmente constituem um complexo mosaico institucional em cada nível de decisão e de atuação, é uma arte da qual dependem em grande parte o sucesso ou o fracasso de um sistema local. As seguintes recomendações podem ser úteis ao administrador local: (a) definir com a maior clareza possível as atribuições e os limites de interferência de cada instância de poder, procurando fazer com que os níveis federal, estadual e municipal se 
complementem e colaborem entre si; (b) estruturar o sistema local com base em objetivos, metas e estratégias de ação; pois são estes os fatores que lhe dão solidez e coerência, e não a estrutura de poder e autoridade ou os interesses particulares de cada instituição; (c) limitar ao mínimo indispensável o número de escalões administrativos e de chefias intermediárias, de modo que 0 sistema se caracterize por uma reduzida complexidade estrutural e pela flexibilidade de modo que possa adaptar-se às contínuas mudanças do meio; (d) obter autonomia de ação para o sistema local, fazendo com que as decisões de interesse da população sejam tomadas perto dela, à sua vista; (e) dar a necessária liberdade funcional a cada componente da equipe de trabalho, pois esta é a única forma de estimular a' criatividade e a inovação. Na descentralização, é preciso acreditar e ter confiança nas pessoas que estão na ponta da rede, mesmo que a princípio - como sói acontecer - o sistema local apresente-se como um todo pouco racional e confuso.

- trabalho por objetivos é o próprio cerne do planejamento estratégico. Exige o estabelecimento de metas a cumprir no médio prazo e, por via de consequência, também no curto prazo e na atividade diária (nenhuma meta estabelecida para dentro de um ano se efetivará se não agirmos de acordo com ela em cada um dos trezentos e sessenta e cinco dias, a partir de hoje). Uma organização local, com limites definidos e população adscrita, pode definir como metas no tempo correspondente a um período de governo, p.ex. que: todas as estações de tratamento d'água estarão fluoretadas; semestralmente todas as crianças em idade escolar receberão uma aplicação tópica de flúor, a proporção de crianças de 5 e 6 anos sem experiência de cáries aumentará em 30\%, o índice CPO-D aos 12 anos diminuirá em 25\%; metade da população entre 15 e 19 anos manterá todos os seus dentes funcionais; as extraçōes serão reduzidas em $1 / 4$; uma de cada três pessoas terá conhecimentos adequados sobre os fatores que causam cáries e doenças periodontais e sobre os meios para preveni-las; o sus estará implantado e a municipalização efetiva alcançará $80 \%$ das cidades; a comunidade participará da definição de ações e da avaliação anual em 708 dos municípios; o SILOS terá um conhecimento adequado sobre as condições epidemiológicas, padrões de utilização dos serviços, fontes de distribuição de produtos açucarados; a cobertura de crianças de 6 a 14 anos será de 608 na zona urbana, etc. Enfim, é imprescindivel que as finalidades e os resultados previstos estejam muito claros para todos - profissionais e população - e que 0 sistema local seja analisado e avaliado em função do seu cumprimento.

\section{:: 9.1.3. Participação Social}

A participação social em uma organização local de prestação de serviços de saúde bucal é um processo social que procura unir a todos os atores presentes em uma zona geográfica determinada para identificar os problemas existentes, desenhar e colocar em prática as soluções possíveis.

A participação processo, o qual no comunitária é entanto não se um componente vital deste esgota nela. Ao envolver as 
entidades de representação classista, organizações políticas e os setores da sociedade que direta ou indiretamente influenciam ou se relacionam com a saúde, torna-se um movimento democrático onde um conjunto social compartilha experiências e conhecimentos na tentativa de construir seu próprio futuro(167).

A organização local certamente representa 0 ambiente ideal para que se efetive e se torne relevante, pois está próxima da população e pode ser por ela influenciada, com um mínimo de canais burocráticos intermediários. Contudo, pode e deve ser exercitada nas demais instâncias - organizações regionais e nacionais representando na prática a mais concreta chance que o setor saúde tem de atuar nos condicionantes externos a ela, e de receber 0 apoio e a critica das demais áreas. Afinal, se grande parte das causas dos problemas de saúde localizam-se fora dos limites das ciências médicas, nada mais apropriado do que conviver e dividir opiniões e soluções com os que lidam com essas causas a fim de tentar remove-las mais facilmente.

Para compreender as relaçōes sociais estabelecidas em cada comunidade e agir para transforma-las, a participação social pode assumir distintas formas: colaboração, cooperação integrada, cogestão, autogestão. A primeira delas, a colaboração, é a linha mais tradicional e em geral significa uma tutela sobre a comunidade $e$ as demais instituiçōes com base na autoridade do conhecimento médico. A cooperação integrada é uma forma mais democrática de relacionamento $e$ se fundamenta na abertura dos setores administrativos e das unidades de saúde para que os demais setores - compreendam e possam discutir caminhos mais adequados para resolver os problemas constatados, ao mesmo tempo em que estes setores viabilizam aos trabalhadores de saúde a discussão e a sua eventual intervenção sobre causas de âmbito geral (p.ex., poluição, miséria, saneamento, desemprego). A cogestão - administração conjunta do sistema local de saúde - e a autogestão, na qual cada unidade assume a direção dos seus próprios serviços e destinos, constituem modalidades mais avançadas de participação social, em geral representando um objetivo a ser atingido tão logo as linhas de cooperação integrada tenham êxito e se consolidem.

A participação comunitária não pode ser forçada. Algumas organizaçōes Iocais de saúde chegaram a pensar que por aí poderia acontecer uma autêntica revolução setorial, e se puseram a concorrer por mais e mais participantes extra-setor, medindo 0 sucesso pelas pessoas que iam às reuniões e pela quantidade de intervençōes/opiniões dadas. Longe de ser uma competição, deve caracterizar-se pela ação independente da comunidade $e$ de seus representantes, com suficiente autonomia para poder analisar as melhores opçōes para alcançar e manter boas condiçōes de saúde.

As unidades de prestação de cuidados odontológicos em sua grande maioria estão pouco habituadas a este enfoque, uma vez que por tradição limitam-se a atender às pessoas que por livre demanda as procuram. Não obstante, neste início de abertura para a comunidade muita coisa pode ser feita. Em primeiro lugar, é muito importante que a unidade odontológica identifique a sua comunidade, 
ou seja, a área e a população que Ihe está adscrita. Ainda que esta adscrição não seja oficialmente feita ou determinada, é possível estabelecer limites razoáveis de influência e dividir territórios e clientela em negociações colaterais com as entidades e clínicas de saúde bucal situadas nas proximidades. Um diagnóstico mínimo sobre os principais problemas e os grupos de maior risco epidemiológico e social, conforme o exposto no Título 9.2, fornece a base para uma primeira discussão com representantes da comunidade e com os próprios grupos de pacientes que diariamente estão buscando atendimento. A partir de um programa básico de ação, no qual a unidade de saúde bucal diz das suas possibilidades, horários, número de profissionais disponiveis, recursos materiais e financeiros, além das prioridades técnicas mais indicadas, a discussão com a comunidade é aberta. Pontos em dúvida e opções quanto a grupos a atender, horários, etc., podem e devem ser tomadas em conjunto. Em alguns casos, associações de bairro ou entidades de ascendência local selecionam os grupos mais críticos de pacientes e os encaminha nos turnos de trabalho disponíveis, ou indica os bairros, agrupamentos, escolas que em seu conceito mais necessitam de cuidados periódicos ou constantes. Uma vez estabelecido um programa em comum acordo, sua execução e seus resultados passam a ser acompanhados e periodicamente analisados pelo conjunto das forças participantes, as quais discutem os motivos para eventuais interrupções ou não alcance do que fora previsto, apontando rotas de correção e novos caminhos a seguir.

As entidades profissionais e as instituiçōes," que comumente compōem uma variada e pouco integrada rede de oferta de serviços públicos e privados, são atores direta e permanentemente comprometidos nesta marcha. Os tradicionais comitês de saúde, compostos apenas por profissionais e caracterizados pelo seu viés técnico, podem ser uma etapa necessária (em geral é difícil até mesmo forma-los e conseguir que as entidades estabeleçam algum tipo de programa coordenado) no começo do processo de participação social, mas logo devem integrar-se à dinâmica de discussões com a comunidade.

A legislação brasileira através da Lei 8.142 que "dispõe sobre a participação da comunidade na gestão do Sistema único de Saúde", prevê a constituição de un Conselho de Saúde em cada esfera de governo (federal, estadual, municipal) composto por representantes oficiais, dos prestadores de serviços, profissionais de saúde e usuários, "para atuar na formulação de estratégias e no controle da execução da politica de saúde, inclusive nos aspectos econômicos e financeiros"(21). Tais Conselhos costumam atuar formando grupos por áreas especificas, uma das quais é a saúde bucal. Este grupo deve ser formado, sempre que possível, tendo a seu cargo a definição da politica e do programa odontológico (incluindo divisão de atribuições institucionais, custos $e$ verbas), os quais. passam pelo crivo do Conselho, onde deve participar o coordenador ou representante da área de saúde bucal. 


\section{: 9.2. Serviços Essenciais e Complementares}

Numa situação de crise geral e de recursos escassos, não se pode esperar verbas elevadas, tornando-se de suma importância a escolha dos problemas a enfrentar e dos grupos a proteger ou tratar. O Quadro 7 procura equacionar estes dilemas estratificando as ações de cada serviço em torno de um elenco de medidas essenciais e um outro de medidas complementares.

QUADRO 7

\begin{tabular}{|l|l|}
\hline \multicolumn{2}{|c|}{ ATENÇÃo ODONTOLóGICA A COMUNIDADES } \\
\hline MEDIDAS ESSENCIAIS & MEDIDAS COMPLEMENTARES \\
\hline Prevenção Coletiva & Atenção a Adolescentes \\
Prevenção Tópica & Proteção a Grupos \\
Educação em Saúde & Especiais \\
Atenção Grupo 6-12 Anos & Serviços de Referência \\
Atenção Grupos Discriminados & Atenção a Adultos \\
Identificação e Encaminhamen- & \\
to de Casos Graves- & \\
Vigilância Epidemiológica e & \\
Sanitária & \\
& \\
\hline
\end{tabular}

As medidas essenciais são aquelas que não podem deixar de ser levadas em consideração por parte de um programa de saúde bucal em qualquer nivel. As complementares relacionam-se a problemas e a grupos também prioritários, mas que podem ser equacionados num segundo momento ou com menor ênfase, considerando que o primeiro bloco venha a exaurir, por si só, com os recursos ou com as disponibilidades iniciais de tempo e de pessoal da unidade de saúde. É no âmbito local que em última análise os conceitos de essencialidade e de complementariedade são decididos e são modificados. Assim, pode haver um programa geral para o Estado que estabeleça como grupo-alvo as crianças de 6 a 12 anos, e ao mesmo tempo diversos municípios reunem condições de prever um alcance superior ( 5 a 14 anos,p.ex.), enquanto outros decidem contentar-se com metas menos ambiciosas ( 6 a 9 anos, p.ex.).

A prevenção coletiva, no caso brasileiro, significa fundamentalmente a fluoretação da água de abastecimento público. A prevenção tópica concentra-se no apoio ao uso de dentifrícios fluoretados e à aplicação tópica profissional periódica de fluoretos, como se expōe no Título 9.2.1. A educação em saúde bucal atua como um suporte às ações preventivas e como um mecanismo de proteção direta à população, estando melhor analisada no Título 9.2.2. A divisão entre crianças de 6 a 12 anos e adolescentes 
justifica-se apenas pela falta de recursos para atender a todos e pela necessidade de enfrentar primeiro os danos iniciais, pelo menos tentando evitar que se agravem, sendo este o tema do Título 9.2 .3 .

Constitui uma obrigação do setor público prover o atendimento das necessidades elementares dos grupos discriminados pela sociedade sob o ponto de vista econômico, geográfico e social, entre outros. Ou seja, em cada localidade ou região, os serviços locais de odontologia não podem eximir-se ao compromisso de ofertar cuidados de urgência, de alívio à dor e do atendimento clínico básico às pessoas que não tem acesso aos serviços disponíveis no mercado. Na prática, é preciso encontrar um equilíbrio dentro de cada unidade de saúde priorizando os grupos de maior carência.Os pacientes com problemas graves, especialmente os casos de câncer bucal, de hepatite, de herpes e de AIDS, devem ser identificados o mais precocemente possivel e ser encaminhados para centros de tratamento apropriados, desenvolvendo-se paralelamente um sistema de prevenção específico dirigido para os grupos de risco. O Título 9.2.4. engloba toda a discussão a respeito do atendimento a outros grupos e problemas, ao passo que os Títulos 9.2 .5 e 9.2.6 tratam dos sub-sistemas de vigilância sanitária e epidemiológica.

As ações que devem compor cada uma das medidas essenciais e complementares estão exemplificadas no Quadro 8. 
QUADRO 8

ATENÇÃO ODONTOLÓGICA A COMUNIDADES:MEDIDAS ESSENCIAIS, COMPLEMENTARES E AÇÕES CORRESPONDENTES

MEDIDAS AÇÕES

Prevenção Coletiva

Prevenção Tópica

Educação em Saúde

Atenção a 6-12 anos

Grupos Discriminados

Casos Graves

Vigilância

Adolescentes

Grupos Especiais

Serviços de Referência

Atenção a Adultos
Fluoretação da água

Apoio a dentifrícios

fluoretados, aplicação

tópica de gel FFA

Medidas de auto-proteção, estímulo ao uso de flúor, orientação para acesso a serviços

Sem custo direto, universal

Oferta de serviços clínicos a pessoas de baixa renda, residentes em periferias urbanas e/ou sem acesso a outras formas de atendimento

Diagnóstico precoce Câncer Bucal, Herpes, Hepatite, sintomas AIDS + encaminhar para cuidados apropriados

Estudos epidemiológicos regulares, controle do teor de flúor na água, controle dos principais produtos preventivos

Cartão de Saúde Bucal, assegurando acesso a cuidados regulares

Cuidados clínicos a deficientes físicos, pessoas confinadas, idosos sem acesso a serviços regulares

Atenção periodontal, de cirurgia, protética, endodôntica, ortodôntica: pacientes com prioridade social, encaminhados pela rede

Cuidados a trabalhadores. 


\section{: 9.2.1. Ações Preventivas}

Para países em desenvolvimento com aıca prevalencıa de carıes, como é o caso do Brasil, o melhor modelo preventivo é aquele que viabiliza o acesso regular a uma combinação entre um método de ingestão e de uso tópico de fluoretos. Adicionalmente recomenda-se a remoção da placa bacteriana dental através da escovação adequada e o controle do consumo de açúcares. A associação de métodos é o caminho mais rápido para obter uma redução efetiva da cárie dental em crianças e adolescentes.

- esquema de prioridades adotado em 89 pela Política Nacional de Saúde Bucal coloca corretamente a cárie dental em primeiro lugar, seguido pelas doenças periodontais, as quais são combatidas principalmente através das ações de educação sanitária que procuram induzir a população a adotar medidas adequadas de higiene oral e da oferta de servilos de profilaxia nas unidades básicas de saude.

Quanto aos métodos de ingestão de fluor para prevenir a carie, certamente a fluoretação da água de consumo público é o mais seguro, simples e efetivo, com a respeitável vantagem de ter tradição e de que suas tecnologias de dosagem e produção são amplamente conhecidas. Tanto o sal de flúor quanto os insumos necessários estão disponíveis no país a custos acessiveis, existindo uma experiência suficiente acumulada nos últimos trinta anos em todas as unidades federadas.

A fluoretação da água deve ser mantida nas localidades onde já existe, adotando-se uma política firme de apoio financeiro, técnico e político para sua expansão a todas as estaçōes de tratamento d'água existentes no país. Um projeto desta ordem é viável por meio da aliança entre os organismos técnicos (Ministério e secretarias de Saúde, entidades de representação profissional) e de financiamento, como ficou demonstrado quando da implementação do PRECAD que previa recursos e estratégias para a sua universalização gradativa.

É importante definir as fontes de abastecimento do sal de flúor e racionalizar o uso do ácido fluossilicico, conferindo prioridade ãs plantas de abastecimento d'água que podem ser alcançadas a custos aceitáveis, ou seja, que estejam relativamente próximas às empresas produtoras do ácido. Deve-se reservar 0 fluossilicato de sódio para as localidades nas quais o emprego do ácido for econômica e/ou geográficamente inviável. Uma alternativa quanto a esta questão está na construção de reservatórios para estocagem em condições seguras de ácido f̧luossilícico, aumentando o seu raio de alcance.

A interrupção do processo de dosagem diminui os efeitos aproximadamente na mesma proporção do tempo gasto para reativa-lo. Isto ocorre por falta de flúor, por deficiências da estação de tratamento ou por desinteresse dos responsáveis locais pela fluoretação. As linhas de vigilância sanitária recentemente implementadas em várias cidades constituem um antídoto 
aparentemente eficaz contra este tipo de problema, estando discutidas no Título 9.2.5.

o método alternativo de fluoretação do sal de cozinha pode ser utilizado nas localidades ou populações sem condições de serem beneficiadas pela fluoretação da água a curto e médio prazo. Para tanto, é preciso assegurar de um lado a utilização de insumos produzidos nacionalmente e, de outro lado, o abastecimento regular de sal fluoretado nestas áreas, evitando sua comercialização nas localidades próximas onde o veículo preventivo adotado for a água a fim de evitar o aparecimento de fluorose consequente ao uso concomitante de duas formas de ingestão de flúor.

Em caso de dúvida quanto ao método a ser usado, deve ser consultada a categoria odontológica local assim como os núcleos de representação da população junto aos serviços de saúde. A política de divisão do país em regiōes segundo o método preventivo, sugerida recentemente, e que reservava Norte, Nordeste e parte do CentroOeste para o sal, não tem sustentação técnica nem viabilidade operacional.

A escovação caseira com dentifrício fluoretado deve ser estimulada ao máximo. Feita corretamente uma vez ao dia, tem um potencial preventivo em torno de $30 \%$ em relação á cárie, além de reduzir e/ou manter sob controle o acúmulo de placa bacteriana que ocasiona doenças periodontais. Programas de escovação supervisionada em escolas de 19 e $2^{\circ}$ graus e em empresas (para trabalhadores) proporcionam resultados semelhantes. Não obstante, a distribuição de escovas e de cremes ou pastas dentais, por seu custo relativamente bem mais elevado e dificuldades de avaliação de resultados, só deve ser tentada pelos programas preventivos que dispuserem de recursos suficientes e que tiverem um padrão de organização que Ihes permita acompanhar 0 desenvolvimento do método. E conveniente evitar a distribuição voluntarista (eventual ou sem controle) e não inserida num programa regular, principalmente nos casos em que a clientela é distinta a cada distribuição.

Torna-se fundamental, no que se refere aos fluoretos tópicos, assegurar-se de que estão sendo efetivamente utilizados.

Considerando a situação imperante no sistema brasileiro de ensino de 12 grau, é preciso optar por métodos que tenham eficácia comprovada, possam ser utilizados em um número mínimo de sessões, tenham custos aceitáveis e larga abrangência, sendo acessiveis a crianças matriculadas ou não.

Aplicaçōes feitas por profissionais (Cirurgiōes-Dentistas ou Técnicos de Higiene Dental) reduzem em cerca de $30 \%$ a ocorrência de novas cáries. De acordo com as análises procedidas no Título 8.2., no Brasil as melhores chances de sucesso concentram-se nos métodos de aplicação tópica semestral, principalmente através de gel flúorfosfato acidulado pela metodologia de fluxo contínuo de crianças (tempo médio de 20 segundos e custo em torno de 15 centavos de dólar em aplicaçōes coletivas). Neste método, uma só aplicação 
anual também proporciona resultados positivos, embora inferiores ao uso semestral, $\circ$ que aumenta sua efetividade em termos populacionais.

A clientela para a realizaçāo de aplicações tópicas profissionais é constituida pela maioria ou pela totalidade das crianças em idade escolar primária. Para conseguir uma abrangência - mais universal possível, empregar táticas semelhantes ás já conhecidas e testadas com êxito pelos programas de imunizaçăo, reunindo a população-alvo, escolarizada ou não, duas vezes por ano nos locais de maior afluxo ou de mais fácil acesso.

Uma alternativa para o gel FFA são os vernizes fluoretados, com a mesma periodicidade, resultados similares, mas custo um pouco mais alto e menor velocidade de aplicação.

o método tradicional de bochechos semanais com fluoreto de sódio só funciona em escolas e programas bem estruturados e não sujeitos a ausências significativas dos alunos. Isto não se dá na grande maioria das escolas brasileiras (vide análise a respeito, no Título 8.4.2.). Apresenta ainda a desvantagem de exigir a presença e a participação semanal de todos os envolvidos, interferindo mesmo que reservadamente na atividade geral da escola.

- programa preventivo não pode prescindir das ações de controle do consumo de açúcar. Embora este seja um tema intimamente ligado à area educativa, é preciso agir de forma permanente através de três iniciativas básicas:

(a) redução dos produtos açucarados nas merendas escolares, principalmente nas que sâo fornecidas ou subsidiadas pelos organismos governamentais. A análise regular (pelo menos com amostras semestrais) do conteúdo de produtos cariogênicos nas merendas fornece um indicador aproximado do sucesso ou não desta medida. Apoiar ativamente a sua substituição por alimentos alternativos à base de micro-nutrientes que favoreçam mais à mastigação e tenham um menor conteúdo de hidratos de carbono complexos(17). O uso de xilitol e de outros substitutos da sacarose é viável sempre que houverem recursos suficientes para tanto;

(b) inclusão de uma inscrição nos pacotes de açúcar e produtos açucarados, dizendo que seu consumo muito frequente ou abusivo é prejudicial à saúde bucal por causar cáries;

(c) apoio à realização e publicação de estudos regionais e locais sobre produção, comercialização e consumo (por faixa etária e por tipo de produto) de açúcar;

(d) apoio à utilização de dietas com menor teor cariogênico, introduzindo alimentos alternativos para reduzir a ingestão de hidratos de carbono.

Todas as atividades relacionadas ao consumo de açúcar não podem ser acríticos, ou seja, feitos exclusivamente sob a ótica odontológica. Há que considerar o papel do açúcar como repositor de 
energias em uma população que em boa parte não tem recursos para adquirir e ingerir as proteinas necessárias ao seu desenvolvimento normal.

\section{:: 9.2.2. Educação em Saúde Bucal}

Atividades educativas são altamente benéficas para toda e qualquer comunidade, as quais sempre podem tirar proveito da transferência de conhecimentos técnicos por parte dos profissionais. Contudo, são precisamente as pessoas mais necessitadas as que menos tempo e condições práticas têm de participar dos programas educativos costumeiramente desenvolvidos no país. Isto ocorre porque estão por inteiro envolvidas com a mais elementar luta pela sobrevivência, tendo que enfrentar carências muito mais vitais que as relacionadas com a saúde oral. Para fazer com que os programas educativos cumpram com seus objetivos inclusive e principalmente junto a estes grupos, é preciso em primeiro lugar que tenham um conteúdo tal que consiga realmente ajudar as pessoas a superar os seus problemas. Além disso, nāo há como isolar as ações de educação em saúde dos problemas vividos no dia-a-dia pela população, tornando-se necessário apoia-la na discussão e na busca de soluções mais globais para que os assuntos específicos - os ensinamentos ligados á saúde da boca - consigam ter penetração e ser assimilados.

Há muito desperdício no trabalho não cientifico de ESB, notadamente pelos gastos com cartazes e materiais inadequados ou distribuidos a êsmo.

Estas constataçōes nos levam a sugerir o uso comedido e direcionado de programas operacionais de ESB. Os objetivos a alcançar com as campanhas educativas devem ser definidos e depois avaliados. No atual momento, quatro temas afiguram-se como os de mais alta prioridade neste campo: (a) uso correto de métodos preventivos da cárie dental a base de flúor, (b) uso adequado de medidas de higiene oral voltadas para a manutenção de níveis de placa bacteriana compatíveis com uma boa saúde dos tecidos periodontais, (c) redução quantitativa do total de açúcar ingerido e diminuição da frequência de consumo, (d) conservaçăo da dentição natural, aceitando extrações dentárias somente como último recurso.

Estes temas devem ser desenvolvidos em vários níveis junto à populaçāo (uma Iinha de mensagens gerais e mais permanentes de alcance global, e outra dirigida para a clientela dos programas), necessitando porém de ativa divulgação de seus princípios e finalidades dentro da classe odontológica. Em particular o quarto tema, Iigado às extraçōes desnecessárias que são endêmicas no país, é vital a compreensão dos odontólogos que em última análise são que as realizam.

Em especial os primeiros temas - controle da cárie e das doenças periodontais - têm dois enfoques práticos no que se refere às açōes educativas: um, de apoio frontal aos programas preventivos em execução, servindo para conduzir a populaçäo a fazer uso real dos métodos adotados (p.ex., valor da fluoretação da água, efeitos 
da fluoretação tópica, períodos e locais de aplicação, grupos beneficiados); outro, voltado para métodos e medidas de auto-ajuda, simples, compreensíveis e eficazes destinados ao uso pessoal e caseiro, com o fornecimento a cada um de conhecimentos e instrumentos acessíveis para que possa cuidar de si mesmo.

Bons programas educativos costumam dar excelentes resultados; se formos capazes de desenvolve-los aí estarão reunidas, na verdade, as melhores chances de ajudarmos as comunidades cuja saúde depende de nosso trabalho.

A avaliação dos resultados previstos é peça básica para superar o atual estágio de empirismo que cerca muitas das ações de educação em saúde. Se as ações de ESB visam, p.ex., que um determinado grupo de pessoas utilize medidas preventivas corretas quanto à cárie dental, deve-se medir os efeitos conseguidos respondendo à pergunta: "que percentual da população-alvo utiliza pelo menos um método preventivo correto com regularidade?". Inquéritos e estudos amostrais junto à clientela podem fornecer com regularidade informações deste tipo, dizendo-nos se os esforços empregados estão sendo úteis ou não.

\section{:: 9.2.3. Atenção a Crianças e a Adolescentes}

Cada localidade e cada estado necessariamente devem ter um programa definido e prioritário de prestação de cuidados odontológicos às crianças em idade escolar elementar, período em que é maior o ataque pela cárie dental.

A cobertura a este grupo figura com destaque no elenco de medidas essenciais, mas para que de fato a cadeia epidemiológica seja interrompida é preciso que as ações preventivas, educativas e curativas básicas cheguem a todas ou à grande maioria das crianças.

Para isto, o programa de saúde bucal deve ter uma abrangência municipal, ou seja: (a) identificar e localizar a população entre 6 e 14 anos residente nas zonas urbana e rural, matriculada ou não nas escolas de 10 grau; (b) estabelecer uma meta de cobertura para atingir em torno de 80 a $90 \%$ das crianças, prevendo um avanço gradual de acordo com os recursos humanos, materiais e financeiros disponiveis (p.ex., 308 no 19 ano, 508 no 29,708 no 39 e 908 no 49); (c) concretizar um acordo entre as diversas instituiçōes prestadoras de serviços (é conveniente envolver os organismos de representação profissional), sob a coordenação da entidade que comanda o Sistema Único de Saúde local, no qual cada uma assume a responsabilidade que the cabe seja por uma determinada área do município, seja por um certo número de pacientes, com metas específicas definidas e claras a serem acompanhadas e ávaliadas por todos; (d) discutir o programa com a comunidade, explicitando conteúdos, razões e principalmente os objetivos e metas a alcançar; (e) cumprir o programa, redistribuindo as cotas de cobertura ou suplementando as ações das instituições que por algum motivo não estejam conseguindo dar conta do recado; (f) definir o sub-programa preventivo coletivo como uma atividade conjunta, se possivel destinada a toda a faixa etária desde o começo. 
Os estudos feitos no Titulo 8.4.2. demonstram que o sistema de atenção ao grupo de 6 a 14 anos tem que ter um caráter municipal com base em unidades instaladas dentro e fora das escolas. Porisso não é conveniente que se mantenha o esquema tradicional de separar a clientela infantil entregando-a exclusivamente ao cargo da Secretaria de Educação ou ao "programa escolar" da Secretaria da Saúde.

Vimos que as crianças entram e saem nas escolas durante o ano, nelas permanecendo em média somente 5,4 anos ao invéz dos oito que compōem o ciclo elementar. Além disto, em torno de 4,2 milhōes de pessoas nessa faixa etária não está matriculada. A partir dos 10 anos muitas trabalham, e é comum que o periodo diário de permanência em sala de aula seja de apenas 3 horas (em geral situase entre 4 e 5 horas). Aos 6 anos parcela significativa da clientela permanece em casa, além de que o ingresso tardio é um fenômeno comum principalmente na zona rural.

A base metodológica para a gradativa universalização do atendimento está na adoção do CARTÃo DE SAÚDE BUCAL.

A partir dos 6 anos de idade, quem obtiver uma alta odontológica receberá o cartão que lhe confere o direito de receber atenção clínica básica, cuidados preventivos e educação em saúde bucal, até completar 14 anos de idade. Quem chegar odontológicamente saudável nesta faixa, receberá um novo cartão estendendo seus direitos até aos 19 anos.

Uma vez que o sistema educacional brasileiro consegue assegurar que até aos 9 anos praticamente a totalidade das crianças estão nas escolas mesmo que por um número,limitado de horas/dia, parece razoável admitir que as unidades de atenção odontológica instaladas nas escolas ou próximas a elas devam assumir responsabilidade praticamente integral sobre a faixa de 6 a 9 anos, quando o cartão pode ficar com o programa, que se encarrega de chamar as crianças atendendo-as regularmente. Desde os 10 anos 0 cartão deve ficar preferencialmente na posse da criança (ou dos pais), a fim de que possa exercer o seu direito ao atendimento junto a qualquer unidade da rede oficial e para-oficial.

o sistema permite um atendimento por ano; quem não comparecer durante dois anos, perde 0 direito, devendo submeter-se a tratamento por conta própria para receber um atestado de que não tem problemas odontológicos para retornar ao sistema e obter um novo cartāo.

Todas as unidades, incluindo as clínicas escolares, centros e postos de saúde, devem estar integrados ao sistema, conferindo prioridade ao atendimento dos portadores do CARTÃO DE SAÛDE BUCAL. o atendimento anual ou bi-anual pode representar uma ou mais consultas e compreende cuidados clínicos básicos (restaurações, extrações inevitáveis), prevenção, educação em saúde bucal, profilaxia. 
Este modelo permite contornar alguns dos problemas que tem dificultado a expansão e 0 exito dos sistemás incrementais tradicionais, tendo a grande vantagem de dividir responsabilidades e compromissos com a própria população o que lhe confere uma característica fortemente democrática. Na prática, os cuidados de manutenção (atendimento dos que receberam alta no ano ou em um dos dois anos anteriores) tendem a adquirir uma regularidade e constância bem maiores garantindo uma boa condição de saúde por mais tempo para as pessoas, que poderão ir á procura de um atendimento que passou a ser um direito seu. Os programas que hoje se dedicam a escolares e que estão bem estruturados continuarão a chamar os seus pacientes e a prestar-lhes cuidados odontológicos periódicos; ao passo que aqueles que tem dificuldades de organização, são inconstantes e não conseguem melhorar seus índices anuais de cobertura, poderão contar com a colaboração e o reforço das demais unidades da rede, para as quais as crianças também passarão a ser tidas como prioritárias, pois neste sistema a prioridade indantil é de todo o sistema local de saúde bucal.

Originalmente os cartões de saúde bucal foram propostos pelo autor como um modelo de proteção à adolescência, sugerindo uma linha compulsória dentro das escolas (ou em clínicas e centros de saúde estratégicamente situados próximos a elas) até os 12 ou 14 anos, e depois uma linha aberta sob controle da clientela (cartões) dos 13 ou 15 aos 19 anos. Estes conceitos continuam válidos, fundamentando-se no fato reconhecido de que crianças que recebem bons cuidados na escola elementar e depois são abandonadas à sua própria sorte, desenvolvem novas e ativas cáries na adolescência e com frequência chegam à idade adulta com problemas dentários quase similares aos dos que não receberam atenção regular na infância. 0 que agora se coloca é que os cartōes são necessários antes, devido à precariedade do sistema escolar de 12 grau. Os adolescentes, segundo grupo em termos de prioridade etária para a odontologia, são assim incorporados de maneira gradual ao sistema de cobertura organizada em saúde oral. Além disso, têm acesso à atenção eventual nos centros e postos de saúde, da mesma maneira que a população em geral.

As açōes preventivas são realizadas individualmente somente nos casos dos pacientes que comparecem para receber cuidados regulares anuais com o cartão de saúde e que não se beneficiaram com os métodos coletivos, como as aplicações tópicas em massa.

A velocidade de progressão do modelo depende da capacidade de abrangência do sistema local de saúde bucal, ligada diretamente à sua organização (coordenação efetiva, integração entre as diversas entidades), à adequação do programa, ao espaço e tempo requeridos pelos demais grupos e problemas $e$ aos recursos humanos $e$ financeiros disponíveis. Com a atual capacidade instalada do setor público e para-oficial - 40.567 postos de trabalho conforme a Tabela 15 - certamente é viável estruturar e implementar programas que na maior parte dos municípios proporcionem a médio prazo, via aumento gradual da cobertura, um bom padrão de saúde oral a um contingente expressivo da população. 
Cada programa define, em última análise, os seus padrões determinando as idades-limite de validade, mecanismos de estímulo à demanda, formas de controle, etc. Infantes com até cinco anos devem ser alvo de medidas preventivas específicas desde o inicio do programa, sendo incorporados ao sistema de atenção regular à medida em que se tornar satisfatória a cobertura de crianças e adolescentes.

\section{MODELO DE CARTÃO DE SAÚDE BUCAL}

Nome:

Data de Nascimento:

Endereço:

Nome do Pai, Mãe ou Responsável:

Identificação da Unidade que forneceu o Cartão:

Este CARTÃO DE SAÚDE BUCAL dá prioridade para atendimento dentário, uma vez por ano, em serviços odontológicos da rede pública.

Pode ser utilizado por pessoas de 6 a 14 anos (ou 15 a 19) que completaram o seu tratamento odontológico em um programa de saúde escolar e dá direito aos seguintes serviços: cuidados preventivos, educação em saúde bucal, profilaxia, restauração de dentes cariados e extraçōes inevitáveis.

Quando o Portador não comparecer a uma unidade de saúde buc al durante dois anos seguidos, perde o direito aqui estabelecid 0 .

Data do Atendimento:

Serviços Realizados:

Medida Preventiva recebida no ano:

Unidade de Saúde que prestou a Atendimento:

Cirurgião-Dentista responsável: 


\section{:: 9.2.4. Atenção a Outros Grupos e Problemas}

Os grupos mais discriminados social e econômicamente e os problemas bucais graves são considerados como essenciais para um sistema local de saúde bucal.

Constitui uma obrigação para o setor público prover o atendimento das necessidades elementares das pessoas com carências mais agudas. Isto significa que as unidades públicas não podem eximir-se ao compromisso de ofertar ao menos cuidados de urgência, de alívio à dor e de clínica básica aos que por motivos geográficos, econômicos ou sociais em geral residentes em locais longínquos ou em periferias marginais urbanas, não têm acesso a outros tipos de serviço.

Em um país no qual largas camadas da população permanecem sem ter como atender sequer suas necessidades primárias de sobrevivência, é natural que uma parcela significativa do tempo das unidades de saúde deva ser reservado para essas pessoas. Em um município, quando existirem diversas clinicas ou consultórios odontológicos, deve ficar claro para a população quais as que estão disponiveis para atendimento geral e em que horários. Sempre que possível este atendimento, que é dado por livre demanda, deve ser programado na base, p.ex., de uma consulta/ano para 508 da população de baixa renda.

Os problemas graves são aqueles que podem colocar em risco de vida seus portadores ou que podem contaminar outras pessoas. Em saúde bucal enquadram-se nestes critérios os casos de câncer oral, hepatite, herpes $e$ as manifestaçōes da síndrome da imunodeficiência adquirida. Sob o signo da essencialidade colocam-se, para a rede básica de saúde pública, a detecção precoce de sinais e sintomas em pacientes com essas enfermidades, 0 atendimento inicial, a adoção de medidas preventivas gerais, o encaminhamento para atendimento especializado e o acompanhamento do caso quando tratar-se de paciente residente em sua área de influência.

São considerados como complementares, portanto para desenvolvimento numa fase em que o programa municipal de saúde oral já tiver conseguido dar um equacionamento adequado aos grupos e problemas essenciais, os chamados grupos especiais e os serviços de referência, conforme o esquema proposto no Quadro 7.

Os grupos especiais reunem particularmente aos deficientes físicos;, às pessoas confinadas em casas de saúde, prisões, etc. e aos idosos física ou mentalmente dependentes. O programa odontológico deve identicar, no município, as pessoas que por problemas motores, psíquicos ou de saúde geral sem recursos financeiros não têm acesso autônomo à rede. Conforme o porte desta clientela e as disponibilidades da rede, pode ser reservada uma unidade, um consultório ou parte do seu tempo para atender a estes grupos em clínica básica, encaminhando quando possível os casos complexos para atendimento especializado (no próprio município ou em localidade próxima). 
Os serviços de referência nas áreas de periodontia, cirurgia, endodontia e ortodontia destinam-se a pacientes enviados pela rede básica (evitar atendimento autônomo, isolado dos serviços básicos) e considerados como prioritários do ponto de vista epidemiológico e social. Diversas Secretarias de Saúde - Paraná, Distrito Federal,são Paulo,p.ex. - possuem serviços nesta linha. É importante ter critérios transparentes e que possam ser aplicados com correção pelas unidades da rede, pois quase sempre a capacidade de atendimento das unidades especializadas é restrita. A unidade da rede que atende escolares, adolescentes, adultos ou os grupos especiais, ao encaminhar um paciente da sua área para atenção especializada, assume também a obrigação de acompanhar o caso, inclusive dando-lhe a necessária manutenção clínica posterior nos casos em que isto for exigido. Não se incluem no âmbito da saúde pública, serviços de alta complexidade, cosméticos ou para pacientes não prioritários.

As doenças periodontais devem receber uma atenção particular, principalmente por se constituirem na segunda grande prioridade de trabalho para a odontológica. Os países que já conseguiram controlar a cárie dental, dedicam hoje seus maiores esforços para encontrar maneiras de reduzir a incidência de problemas periodontais em suas populações. No caso brasileiro, as ações a nível de saúde pública concentram-se no campo da educação em saúde objetivando a máxima difusão possível de práticas adequadas de higiene oral pela população, e na oferta de serviços de profilaxia e de escovação orientada para grupos de escolares e de adultos(57,87). Esta é também una área de grande importância para 0 desenvolvimento de estudos epidemiológicos e clínicos (vide Título 9.5).

A prótese pode ser ofertada, limitando-se em geral a peças totais e as vezes também parciais removíveis, e desde que não implique em custos para o serviço. Em geral é possivel utilizar espaços disponíveis nas unidades ou horários livres para esta finalidade. O melhor regime, no caso de próteses, é o de cobrar o preço de custo oferecendo aos pacientes uma opção de qualidade e baixo preço. Dividir os gastos com recursos humanos, material de laboratório e demais insumos pela produção, de formas a chegar ao preço por peça.

- desenvolvimento de ações de proteção à saúde oral da população de terceira idade é, cada vez mais, um componente necessário da programação local, considerando-se os índices muito elevados de problemas e as severas dificuldades de acesso que caracterizam este grupo(82,204). Uma pauta de trabalho especificamente dirigida para os idosos inclui a prestação de cuidados clínicos para as pessoas de maior carência (total ou parcialmente dependentes, de baixa renda) e o direcionamento de parte do sub-programa educativo para difundir ações de autocuidados em relação à higidez dos tecidos moles, de manutençāo em bom estado das próteses existentes e do combate às extraçōes desnecessárias ${ }^{(82,143)}$. 


\section{:: 9.2.5. Vigilância Sanitária}

Um bom sistema de controle em relação à qualidade dos produtos preventivos comercializados no país e à quantidade de fluoretos consumidos pela população, é essencial para assegurar a obtenção de resultados consistentes com os métodos empregados seja a nível de saúde pública seja individualmente.

O sistema de vigilância sanitária existente no Brasil tem como centro uma unidade técnica na estrutura do Ministério da Saúde que credencia os produtos possibilitando sua utilização e, nos estados e municípios, baseia-se nas Secretarias de saúde que exercem a fiscalização operacional. E um sistema que funciona sob pressão, assoberbado com a tarefa de exercer um controle permanente de qualidade sobre uma imensa gama de produtos que com frequência não obedecem as formulações aprovadas pelo Ministério. Na prática, a fiscalização é feita em atendimento a solicitaçōes específicas, a denúncias ou diante de notórias irregularidades. Quando, p.ex., um produto é autuado e retirado das prateleiras dos super mercados, se o produtor for um grupo com grande poderio econômico, é bastante provável que se torne muito difícil para a autoridade sanitária manter o veto à sua comercialização por muito tempo, tantas são as pressōes que costuma sofrer.

Dificilmente, no momento, seria razoável imaginar que esse sistema possa controlar com a assiduidade e a prioridade que se deseja o universo de produtos da área odontológica. 0 mesmo raciocínio pode ser aplicado à questão da qualidade da água.

A solução está em estruturar um sub-sistema específico de controle a cargo das instituiçōes odontológicas - coordenadorias de saúde bucal das secretarias de Saúde e laboratórios das Faculdades com a participação das entidades de representação profissional mediante um acordo profissional com as autoridades oficialmente encarregadas da vigilância. Este acordo é fundamental para validar - trabalho que venha a ser desenvolvido pelo setor odontológico, uma vez que no momento em que um laudo qualquer apontar irregularidades como dosagens inadequadas e eventualmente danosas para o organismo humano, só será aceito se tiver validade legal ou se for acatado como tal. Muitas Secretarias de Saúde já adotam o credenciamento de laboratórios de instituições públicas e de universidades para testar a qualidade de determinados produtos, podendo esta tradição ser consagrada para permitir uma fiscalização regular pelo menos sobre os produtos utilizados para a prevenção das doenças bucais.

Neste campo, os dentifrícios fluoretados, geis e soluções para aplicação tópica profissional e soluções para bochechos com flúor são os de mais amplo uso seja pela população seja pelos odontólogos em seus consultórios ou nos programas de saúde pública. Os dentifrícios e as soluções para bochechos diários (com 0,058 de fluoreto de sódio) têm suas dosagens e limites estabelecidos em portaria do Ministério da Saúde, o que torna mais fácil a análise da adequação ou não das formulações à venda no comércio e casas especializadas. Quanto aos demais, os teores de flúor que os torna 
efetivos são conhecidos (p.ex. soluções para enxaguatórios semanais contém fluoreto de sódio a 0,28$)$, permitindo comparações imediatas com o conteúdo dos produtos examinados em laboratório.

A segunda grande vertente para o trabalho de vigilância sanitária em odontologia refere-se ao controle do teor de flúor na água de abastecimento público nas localidades onde este método é realizado.

Uma vez que os sistemas existentes $(1,156,169,209,210)$ se consolidem e se expandam, nāo há dúvida de que teremos em funcionamento um dos mais eficazes métodos de sustentação da fluoretação da água no país, principalmente se considerarmos que as inconstâncias, as subdosagens e a interrupção pura e simples da adição de flúor tem sido responsáveis pela não redução (ou pela redução em níveis abaixo do esperado) da cárie dental em muitas cidades brasileiras que tem utilizado esta medida.

Na cidade de são Paulo, de um total de 291 amostras d'água colhidas pela secretaria Municipal de saúde em sessenta pontos distintos durante o 12 semestre de 1.991 , 35\% estavam abaixo do teor de $0,6 \mathrm{mg}$ de flúor por litro considerado como mínimo aceitável (em 1.990 esta proporção foi de $27 \%$ )(210).

Quando uma cidade ou um estado optar por um sistema de controle independente do que é normalmente praticado pela Companhia de Abastecimento D'Água, é fundamental ter bem claro que se trata de uma linha de apoio às estaçōes de tratamento pois, em última análise, são elas que efetivamente fazem prevenção ao aplicar o flúor à água. o método preventivo de massa que cabe à profissão executar é o de aplicações tópicas de flúor.

Para implementar um sistema de vigilância sobre o flúor contido na água de consumo público de uma cidade, seguir o seguinte roteiro:

(a) contactar a Companhia de Abastecimento D'Água e o órgão de vigilância sanitária locais para definir um programa conjunto de ações ou, no mínimo, evitar reações contrárias às atividades de controle de qualidade a serem iniciadas;

(b) definir um laboratório idôneo e adequadamente instrumentado para realizar as análises da água. As principais opçōes estão na utilização dos equipamentos da universidade (quando existente na cidade ou em localidade próximal reforçando-os se necessário, na montagem de um pequeno laboratório específico para esta finalidade ou na contratação de serviços disponíveis no mercado;

(c) determinar os locais de obtenção das amostras d'água e efetuar a coleta regularmente. No período de um ano de trabalho, os locais não devem mudar. As coletas devem ter no mínimo uma periodicidade semestral, e sempre que possivel mensal, abrangendo pontos variados e representativos da rede. Estes pontos devem estar situados próximo à saida da água da estação de tratamento, de 
reservatórios e de poços que estejam injetando volumes adicionais de água à rede, além de em lugares de alto consumo humano e em periferias urbanas. Uma planta da rede de distribuição da água é de grande utilidade. No programa de monitoramento implantado no estado de São Paulo, foi fixado um mínimo de cinco amostras para as cidades pequenas e de sessenta para a capital, recomendando-se, no caso das residências, coletar a água antes da entrada no prédio para evitar uma eventual interferência de filtros caseiros de carvão ativado sobre o teor de flúor(156);

(d) organizar a dinâmica de entrega, recebimento e envio regular dos tubos de coleta d'água, cuidando para que todos sejam corretamente etiquetados com a data da amostra e local exato onde foi obtida;

(e) ao ser feita a análise, os achados devem ser comparados com os dos laboratórios da Companhia de Abastecimento D'Água para checar possíveis assintonias e coincidências. Os resultados, uma vez consolidados e firmes, devem ser divulgados para conhecimento da população e discussão com os seus representantes junto ao sistema de saúde. As dosagens insuficientes ou que estiverem acima do programado deverão estar regularizadas nas coletas seguintes, com a correção das suas causas (em geral, problemas da aparelhagem, falta de flúor, deficiências operacionais da estação, incorreções na concentração do íon flúor ou na taxa de umidade, etc. do sal que estiver sendo utilizado).

Para o caso de desejar aplicar esse sistema em algumas cidades de maneira que sejam representativas do conjunto, pode ser utilizado 0 método sugerido a seguir para a vigilância epidemiológica.

A avaliação desse sistema é feita diretamente através da comparação da proporção de pontos de abastecimento com dosagem adequada, verificando se está havendo uma melhora ou não, e indiretamente por meio de estudos epidemiológicos que atestam os níveis de redução da cárie dental consequentes ao uso correto da fluoretação.

\section{:: 9.2.6. Vigilância Epidemiológica}

A base qualitativa de um bom programa está na vigilância epidemiológica, ou seja, na análise periódica e regular das condições de saúde da população para conhecer as tendências de comportamento das principais doenças a que está sujeita.

No Brasil, a tradição maior tem sido de realização de estudos de prevalência da cárie dental e as vezes das doenças periodontais. Algumas cidades com fluoretação da água ou com programas preventivos mais amplos, como Barretos e São José dos Campos p.ex., tem realizado exames populacionais metódicos para acompanhamento dos resultados obtidos, mas ainda são exceções em relação ao conjunto do país. 
Para criar uma nova tradição, é preciso adotar um método suficientemente simples e que possa ser implantado através da rede de serviços disponível, com base nos conhecimentos já existentes, abarcando os problemas e os grupos de maior prioridade. Uma proposta que inclua muitos e complexos indicadores dificilmente terá êxito nas condiçōes atuais da rede. Uma vez começado, haverá necessidade de consolida-lo no tempo evitando as habituais interrupções a cada troca de administração, para então acrescentar novos índices e aumentar a sua abrangência.

o sistema brasileiro de vigilância epidemiológica em saúde bucal visa conhecer e acompanhar a evolução dos principais problemas de saúde bucal da população, com base na realização periódica de exames em algumas cidades que representem estatísticamente o total para cada unidade federada.

Em sintese as características e o esquema básico de execução do sistema estão descritos nos tópicos a seguir:

- Inicialmente, como padrão mínimo a ser seguido dois indicadores devem ser obtidos: percentual de crianças de ambos os sexos sem experiência de cárie nas dentições permanente e temporária $(C P O$ e ceo $=0)$ e o Indice $C P O-D$, ambos nas idades de 6 , 9 e 12 anos.

- Quando viável, ou gradativamente, acrescentar dados para as demais idades com ênfase nos $4,15,18$ e grupo de 35-44 anos, indices sobre doenças periodontais, próteses totais em adultos, além de hábitos e opiniōes de cada comunidade.

- o número de pessoas a serem examinadas deverá ser determinado de acordo com as condições práticas de cada programa, não devendo ser inferior a 200 por idade nos estados menores.

- Cada Estado é dividido em três estratos: um primeiro composto pela capital, um segundo reunindo as cidades de porte médio e um terceiro com todas as demais. A definição do "porte médio" é variável, sendo que neste caso é utilizado somente um critério populacional, considerando nesta categoria os municípios com um total de 50 mil habitantes ou mais nos Estados de Minas Gerais, Rio de Janeiro, São Paulo, Paraná e Rio Grande do Sul, e com 40 mil ou mais em todos os demais à exceção de Acre, Amapá, Roraima e Tocantins nos quais o limite mínimo é de $25 \mathrm{mil}$. Na Tabela 40, mostra-se a distribuição resultante da adoção destes critérios para o país, com o número de municípios e a população reunida em cada estrato por unidade federada e região. Ainda que a grande massa de localidades. fique situada no terceiro estrato a maior concentraçāo de pessoas está no segundo, que para o total do país inclui 535 municípios e 398 da população. Nas capitais residem 258 dos brasileiros enquanto que $36 \%$ encontram-se nas 3.882 cidades menores.

- Em cada estrato existem dois conjuntos, um com as cidades que tem flúor na água de abastecimento e outro das que não contam com esta medida. Faz parte do primeiro conjunto a localidade onde 
eventualmente o veículo de ingestão de flúor for o sal de cozinha. No Anexo VI estão listados os municípios de porte médio, que compõem o segundo estrato.

- Formado o estrato, pode-se selecionar um ou vários municípios (quanto maior a abrangência da amostra, melhor), de acordo com as possibilidades de cada programa e de cada estado. No Levantamento Epidemiológico nacional, p.ex., optou-se por efetuar os exames apenas nas capitais diante da impossibilidade financeira e prática de deslocar equipes por todo o país.

- A amostra é aleatória com probabilidade proporcional ao tamanho do município. Isto significa que cada município tem uma chance de ser sorteado (fazer parte da amostra) correspondente à sua população. Como exemplo, tomemos a cidade de Uberaba, com 276 mil habitantes estimados em 89, portanto fazendo parte do 29 estrato de Minas Gerais (porte médio) que tem cerca de $5.993 \mathrm{mil}$ pessoas (37,738 da população do estado conforme as Tabelas 9 e 40); sua probabilidade seria de 46 em 1000. Já Juiz de Fora com 378 mil teria 63 em 1000 e Araxá (67 mil) só 11 em 1000.

- Sorteados os municípios que compõem a amostra de cada estrato (a capital tem auto-representatividade), é de todo conveniente que não sejam mudados ou substituidos por um razoável período de tempo, de preferência mantendo-se os mesmos por cinco anos. É melhor escolher bem (alguns municipios por serem inacessiveis ao serviço de saúde bucal podem não ser incluidos para efeitos da amostragem) a poucas localidades e realizar ainda que modestamente o estudo, do que desenhar uma ambiciosa amostra que depois se mostre inviável por seus custos elevados ou pela falta de recursos humanos para concretiza-la. Caso haja problema para realizar os exames em uma localidade, é preferível acrescentar outra, procurando no ano seguinte trabalhar normalmente em todas elas. Embora neste caso o tamanho dos estratos tenha sido definido em função da população total, no começo apenas a população urbana é examinada. Os residentes na zona rural deverão ser incluidos numa segunda etapa, tão logo o sistema urbano esteja funcionando satisfatoriamente.

- Com os núcleos amostrais definidos, estabelece-se o número de pessoas em cada grupo etário a ser examinado em cada cidade. Na. hipótese de que sejam 2.000 crianças de 12 anos em uma amostra com cinco municípios, proceder da seguinte forma: formar um sub-estrato só com a população dos cinco, redefinindo a probabilidade de cada um em função deste total de habitantes e aplicando a mesma proporção ao conjunto de crianças a examinar. Exemplificando, consideremos que no 30 estrato de Alagoas tenham sido sorteadas as localidades de Belo Monte (6700 habitantes), Canapi (21600), Messias (10200), Pilar (33800) e São Brás (8700), com uma população total de 81.000 pessoas. Em consequência, serão examinadas 165 crianças em B.Monte (porque sua população representa $8,27 \%$ de 81 mil) e nas demais respectivamente 533 - 252 - 835 e 215 .

- Repetir os exames com intervalo anual. Não há necessidade de examinar as mesmas crianças, mas sim de ir à mesma cidade. Este 
procedimento justifica-se porque o interesse do sistema de vigilância é de ter um dado epidemiológico representativo da população e não apenas de um limitado grupo da comunidade. Evita-se assim as pesquisas, comuns na área acadêmica, que incluem exclusivamente os poucos pacientes que de fato fizeram uso de uma determinada medida preventiva, comparando-os com os que não a utilizaram. O que deve melhorar é a saúde global em cada município.

- As equipes examinadoras preferentemente devem ser as mesmas e locais. O emprego de equipes centrais que se deslocam para as cidades amostrais pode ser uma opção em alguns estados, mas tem as desvantagens de representar custos maiores que as vezes impedem a continuidade do estudo e de dar um carater de controle externo ao processo epidemiológico. O treinamento, que inclui a aplicação dos índices propriamente ditos e a explicação cuidadosa da importância que tem a dinâmica (com ênfase na periodicidade regular), deve ser uniforme para todas as equipes, renovando-se nas ocasiões de acréscimo de novos índices, quando forem detectados problemas de execução e nos casos de necessidade de substituição de recursos humanos.

- Ainda que seja importante e aconselhável estratificar a população por sua condição econômica e social, inicialmente o sistema limita-se a estuda-la globalmente, sem diferenciaçōes. Quando estes fatores forem levados em consideração, a amostra obviamente crescerá pela formação de sub-estratos específicos para cada novo grupo.

o sistema de vigilância epidemiológica construido sobre esses fundamentos tende a melhorar com o tempo, à medida em que aumente sua representatividade seja através da inclusão de novos estados e municípios, seja por se tornar mais completo ao reunir indicadores sobre outros problemas de saúde oral. 
TABELA 40

DISTRIBUIÇÃO DAS CIDADES E DA POPULAÇÃO TOTAL POR

ESTADO E REGIẢO, SEGUNDO O MODELO DE SISTEMA DE VIGILÂNCIA

EPIDEMIOLOGICA EM TAESS ESTRATOS. BRASIL. 1989.

\begin{tabular}{|c|c|c|c|c|c|c|c|}
\hline $\begin{array}{l}\text { REGIÃO/ } \\
\text { ESTADO }\end{array}$ & $\begin{array}{c}\text { CIDADES } \\
\text { (Total) }\end{array}$ & $\begin{array}{c}\text { ESTAATO } \\
1 \\
\text { CIDADES }\end{array}$ & $\begin{array}{l}\text { (Capitais) } \\
\text { POPUL. }(\%)\end{array}$ & $\begin{array}{c}\text { ESTRATO } \\
2 \\
\text { CIDADES }\end{array}$ & $\begin{array}{c}\text { (Porte } \\
\text { Medio) } \\
\text { POPUL. }(\%)\end{array}$ & $\begin{array}{c}\text { ESTRATO } \\
3 \\
\text { CIDADES } \\
\end{array}$ & $\begin{array}{c}\text { (Pequeno } \\
\text { Porte) } \\
\text { POPUL.(\%) }\end{array}$ \\
\hline NORTE & 311 & 7 & 29,25 & 51 & 34,52 & 253 & 36,23 \\
\hline$A C$ & 25 & & 39,32 & 4 & 37.13 & 20 & 23.55 \\
\hline$A M$ & 62 & & 50,91 & 4 & 11,26 & 57 & 37,83 \\
\hline AP & 9 & & 60,08 & - & - & 8 & 39,92 \\
\hline PA & 105 & & 23,81 & 28 & 44,59 & 76 & 31.60 \\
\hline RO & 23 & & 21,16 & 7 & 46,03 & 15 & 32,81 \\
\hline RA & 8 & & 56,92 & - & - & 7 & 43,08 \\
\hline TO & 79 & & 1,66 & 8 & 34,58 & 70 & 63,76 \\
\hline NORDESTE & 1462 & 9 & 19,29 & 183 & 32,24 & 1270 & 48,47 \\
\hline AL & 97 & & 21,88 & 8 & 22,46 & 88 & 55.66 \\
\hline BA & 367 & & 17.20 & 48 & 29,44 & 318 & 53.36 \\
\hline CE & 178 & & 27,54 & 32 & 32,37 & 145 & 40,09 \\
\hline MA & 136 & & 12,16 & 30 & 43.38 & 105 & 44,46 \\
\hline PB & 171 & ' & 13,41 & 10 & 27,03 & 160 & 59.56 \\
\hline$P E$ & 167 & & 18.51 & 33 & 44,61 & 133 & 36,88 \\
\hline PI & 118 & & 20,02 & 12 & 26,32 & 105 & 53,66 \\
\hline RN & 152 & & 24,74 & 6 & 17,08 & 145 & 58,18 \\
\hline SE & 76 & & 27,85 & 4 & 15,32 & 71 & 56,83 \\
\hline SUDESTE & 1430 & 4 & 30,13 & 187 & 45.80 & 1239 & 24,07 \\
\hline ES & 66 & & 11,08 & 13 & 55.70 & 52 & 33.22 \\
\hline$M G$ & 723 & & 14,56 & 55 & 37,73 & 667 & 47,71 \\
\hline RJ & 69 & & 43,31 & 25 & 49,73 & 43 & 6.96 \\
\hline SP & 572 & & 33,65 & 94 & 47.34 & 477 & 19.01 \\
\hline SUL & 862 & 3 & 13,13 & 89 & 41.12 & 770 & 45,75 \\
\hline PR & 318 & & 15.17 & 29 & 34,27 & 288 & 50,56 \\
\hline RS & 333 & & 14.80 & 38 & 45,74 & 294 & 39,46 \\
\hline SC & 211 & & 5,36 & 22 & 45,68 & 188 & 48,96 \\
\hline C.OESTE & 379 & 4 & 37,62 & 25 & 20,62 & 350 & 41,76 \\
\hline DF & 1 & & 100.00 & - & - & - & - \\
\hline GO & 211 & & 25,43 & 11 & 23,84 & 199 & 50.73 \\
\hline$M S$ & 72 & & 24.51 & 8 & 29.46 & 63 & 46,03 \\
\hline MT & 95 & & 17,19 & 6 & 24,96 & 88 & 57,85 \\
\hline BAASIL & 4444 & 27 & 24,89 & 535 & 38.88 & 3882 & 36.23 \\
\hline
\end{tabular}

Fonte: Bibliografia 4. 


\section{: 9.3. Política de Recursos Humanos}

Há uma evidente necessidade de profissionalização do pessoal que se dedica a fazer saúde pública no Brasil. Esta profissionalização pode ser traduzida na criação de condições práticas que viabilizem uma dedicação em tempo total, dando competitividade ao setor no confronto com a área privada.

Anteriormente já se discutiu não só as vantagens, como a virtual inevitabilidade da existência de serviços públicos eficientes em uma nação constituida por uma maioria de pessoas que não têm chance de acesso a serviços privados. Contudo, mantem-se como regras de um lado a contratação de pessoal a tempo parcial e, de outro lado, o credenciamento de odontólogos e de clínicas privadas para atender a população sob remuneração proveniente dos cofres da nação.

Nessas condições e apesar da notória preferência que a categoria demonstra pelos empregos a tempo parcial, uma organização local ou um serviço que tenha como objetivo alcançar uma efetiva melhora nos padrōes de saúde da comunidade a seu cargo, deve sempre que possível optar por odontólogos, pessoal técnico e auxiliar que trabalhem em regime de 8 horas diárias.

Diante do esgotamento da modalidade indireta de prestação de serviços, os profissionais credenciados pelo INAMPS que ainda estiverem em plena atividade, ou seja, recebendo remuneração mensal regular pelos atendimentos realizados em seus consultórios, devem poder optar por empregos diretamente remunerados pelas secretarias estaduais ou municipais de saúde que desenvolverem o programa local de saúde bucal.

A questão salarial é vital neste processo de fortalecimento dos serviços públicos, os quais só podem competir em condições próximas às do setor privado se remunerarem de maneira adequada ao seu pessoal. Para tanto, torna-se relevante também a unificação dos diversos empregos possibilitando o exercício em um só local de trabalho. Para contornar a costumeira multiplicidade institucional, sugere-se que no âmbito de cada sistema local ou de cada cidade seja feito um mapeamento do conjunto de empregos, discutindo com os interessados a melhor solução para que cada profissional possa realmente dedicar-se à população adscrita a cada unidade (clínica, centro de saúde,etc.). De fato, como pode uma comunidade identificar 0 seu odontólogo ou 0 seu médico, se êles mudam constantemente de posto de trabalho e se permanecem tão somente um curto espaço de tempo na unidade? Na mesma linha de raciocínio pode-se perguntar como pode um profissional identificar uma comunidade como sendo de sua responsabilidade, quando para sobreviver precisa deslocar-se varias vezes durante o dia e ocupar dois, três ou mais empregos em cada um dos quais mal tem tempo para dar um atendimento clínico as mais das vezes rigorosamente impessoal aos que se encontram na fila de espera por seus cuidados?

Um programa de treinamento para os Cirurgiões-Dentistas que atuam nos sistemas locais de saúde é fundamental para assegurar a 
sua adequada implementação. A ênfase recai nos aspectos programáticos com base no exposto nos Títulos 9.1 a 9.9 , no desenvolvimento de capacidade gerencial e na compreensão dos princípios do planejamento estratégico. As Faculdades de odontologia em geral ainda hoje preparam um odontólogo predominantemente clínico, que exige - além da remoção de parte do verniz que o recobre - uma preparação que o capacite a lidar com grandes massas populacionais, ajudando-as a resolver seus principais problemas.

Nos serviços oficiais, não pode ser deixado de lado, como um elemento secundário no rol de deficiências atuais, o tema do cumprimento das condições acordadas quando da assinatura do contrato de trabalho. O tempo de ausência injustificada da clínica é um tempo que não mais é recuperado pela clientela, uma vez que a capacidade de atendimento é limitada e insuficiente para cobrir a demanda. Assim, os detalhes relativos aos horários de trabalho com frequência assumem relevância inicial, considerando que o sucesso do sistema e da desejada participação social em boa parte está ligado ao cumprimento dos compromissos assumidos previamente por parte do pessoal contratado.

Em sintese, no que se refere aos Cirurgiōes-Dentistas, deve-se evitar o exercício a tempo parcial, a dupla militância, a ação privatizada (credenciamentos pela previdência social) e a multiplicidade de empregos, através da efetiva implantação de sistemas locais de saúde bucal fundamentados no modelo de ações essenciais e complementares, sob remuneração e condições de trabalho condignas e competitivas.

A Intensificação do treinamento e contratação de Técnicos de Higiene Dental -THDs- e de pessoal auxiliar em todo os níveis surge como uma consequência natural do esquema de ação até aqui proposto. A linha de preparação em serviço, através de cursos dados pelas próprias instituições que prestam atendimento ao público, merece ser privilegiada.

Os cursos de capacitação promovidos pelas faculdades têm a vantagem de aproveitar a estrutura de ensino já existente e podem ser uma boa alternativa para alguns estados e municípios. Suas desvantagens situam-se no relativo isolamento das instituiçōes de ensino e nos custos que comparativamente por vezes tem sido mais elevados, em geral devido à exigência de muito tempo para atividades teóricas e à utilização de uma gama muito ampla de professores ou à sofisticação dos currículos. o pessoal técnico e auxiliar deve atuar em tempo integral, não se justificando os casos em que são feitos acordos de base salarial que reduzem o período diário de trabalho para cerca de seis horas, uma vez que este tempo costuma ser incompatível com o horário dos odontólogos e com a própria dinâmica de funcionamento das unidades de saúde, afetando de maneira significativa a produtividade geral.

Os THDs podem dedicar-se a dois tipos de atividades curativas, envolvendo 0 apoio ao tratamento clínico de lesões de cárie e de doenças periodontais, problemas ortodôntiocos, etc.; e 
preventivo-educativas, quando a ênfase recai na atenção à população sadia ou, mais exatamente, em evitar que surjam maiores problemas que os já existentes. Tem sido comum que esses profissionais atuem com simultaneidade nos dois campos, mas é cada vez mais frequente que os serviços utilizem um tipo de auxiliar, cujo perfil situa-se próximo ao do Atendente de Consultório Dentário, que atua de fato como um agente preventivo.

\section{: 9.4. Custeio e Remuneração dos Serviços}

Os recursos públicos, aí incluidos os que se originam das contribuiçōes sobre as folhas de salários, devem ser empregados em cada nivel de governo para custear programas estruturados segundo o modelo de ações essenciais e elementares exposto no Título 9.2.

- financiamento das atividades de saúde oral seque, em suas linhas gerais, o mesmo esquema adotado para as açōes de assistência geral à saúde. De acordo com a Lei $8142 / 90$ os recursos do Fundo Nacional de Saúde devem ser repassados para fundos similares existentes ou a serem criados nos estados e municípios. As transferências de verbas do poder central seguem critérios ligados à representatividade populacional, situação sanitária, desempenho da rede, entre outros $(20,21)$.

Estudiosos da área $(148,149,230)$ tem colocado dois aspectos entre as principais dificuldades ainda não superadas no relacionamento financeiro entre os diferentes níveis de governo: a indefinição sobre que recursos fazem parte dos Fundos, os quais as vezes se limitam tão somente às tradicionais verbas de saúde pública excluindo 0 custeio das atividades costumeiramente ligadas à previdência social (hospitalização, assistência médica e odontológica), e a burocracia que cerca os repasses.

Para que os serviços locais efetivamente assumam a responsabilidade pela atenção à saúde da população, é preciso uma maior automatização nas transferências, as quais deveriam incluir o dinheiro relativo à manutenção de todas as atividades usuais curativas, preventivas e educativas - de maneiras a que apenas as verbas de investimento e de combate a problemas como epidemias e problemas emergenciais fiquem sujeitas a negociação. A aplicação de critérios para repasse automático baseados no exemplo dos Fundos de Participação dos Estados e dos Municípios (Artigos 157 a 162 da Constituição)(18), adaptados às características do setor saúde, certamente constitui um avanço necessário.

- sub-sistema de saúde bucal, para que possa consolidar-se precisa, em primeiro lugar, estabelecer o seu programa definindo os padrões possiveis de cobertura populacional e de melhora dos níveis de saúde bucal, definir o orçamento que sustentará sua execução e lutar para assegurar os recursos e para rege-los autonomamente.

A distribuição de responsabilidades e atribuições é variável segundo $o$ universo de instituições existente em cada município, estado e no país, mas a direção única estabelecida nas leis básicas 
do setor deve ser exercida respectivamente pela Secretaria de Saúde municipal, estadual e pelo Ministério da Saúde.

o montante de recursos necessários para financiar as ações de saúde bucal depende da amplitude e da profundidade com que trabalha cada organização local (aproximadamente, as ações odontológicas tem utilizado entre 8 e 208 - com uma média de 158 - dos recursos para assistência ambulatorial alocados antes pelo SUDs e agora pelo SUS) .

Um elenco preliminar de critérios gerais para orientar as transferências dos recursos federais para os demais níveis, e também dos estados para os municípios, estão formulados em seguida:

(a) população prioritária adscrita

(b) quadro epidemiológico em crianças e adolescentes

(c) cobertura preventiva

(d) cobertura com atenção básica aos grupos prioritários

(e) performance da rede de prestação de serviços

Com exceção do segundo critério, todos os demais tem uma relação direta, ou seja, quanto mais pessoas adscritas, cobertas, etc., maior é o volume de recursos alocados. No caso da situação epidemiológicas são privilegiados os locais onde os indicadores são mais criticos.

No ajuste entre as verbas necessárias e as disponíveis, há que preservar em primeiro lugar as açōes mais essenciais, p.ex., os sub-programas preventivo, educativo, de atenção básica a crianças e de cuidados mínimos à população em geral. Quando da negociação, é possivel escalonar prazos e padrōes de cobertura, desde que se mantenha claro o horizonte de quando serão alcançadas as metas. Um exemplo neste sentido é o do sistema local que inicialmente previu, entre outras metas para o ano de trabalho, fluoretar a água nas três estações de abastecimento existentes, realizar aplicaçōes tópicas em $70 \%$ das crianças de 6 a 14 anos, atender $40 \%$ deste mesmo grupo, colocar à disposição uma consulta/ano para 408 da população do município. Diante da escassez de recursos, as duas primeiras metas foram mantidas integralmente, redimensionando-se a terceira para $25 \%$ das crianças e a quarta para $30 \%$ com acesso limitado às pessoas de baixa renda.

É fundamental que os recursos disponíveis façam parte de um só bolo, pelo menos para financiar as atividades das instituiçōes públicas. Isto significa que: (a) o anacrônico regime de pagamento por atos clínicos e preventivos implantado pelo INAMPS em 1991 (37) deve ser substituido por mecanismos mais automáticos de repasse que privilegiem os estados e municípios que efetivamente estiverem trabalhando dentro de princípios de saúde pública; (b) os controles financeiros, uma vez que os critérios estejam bem definidos, podem ser exercidos pelos organismos de acompanhamento já estabelecidos 
como os tribunais de contas, ao passo que os indicadores ligados ao nível de saúde (vigilância epidemiológica), de desempenho, etc., constituem componentes normais de um sistema razoavelmente bem estruturado de atenção odontológica; (c) os serviços públicos diretos devem receber a totalidade ou grande parte dos recursos, interrompendo-se a prática de credenciamentos de profissionais que prestam serviços em suas próprias clínicas Formas inovadoras de remuneração tornam-se necessárias para superar a situação vigente na maioria dos serviços onde os problemas consequentes à má remuneração e ao não cumprimento dos padrões contratuais (quebras de horários, atendimento impessoal ou descortês, reduzido interesse pela melhora do quadro epidemiológico, parca integraçāo com a comunidade, etc.) são comuns. Duas medidas podem ser aplicadas, na dependência das características de cada programa:

- local único de trabalho, através do mapeamento dos diversos empregos do pessoal profissional em atividade no município, favorecendo os que se fixarem em tempo integral. Num momento inicial os salários pagos por parte de cada instituição podem ser mantidos, prevendo-se a regularização dos vínculos funcionais (contrato com o órgão em cujas instalações o profissional exerce o seu emprego) a médio prazo;

- estímulo financeiro adicional ao salário, condicionado principalmente ao alcance e à manutenção de níveis de saúde bucal adequados na população adscrita. Isto corresponderia a assegurar um salário digno para cada membro da equipe odontológica, acrescentando um "plus" referente ao cumprimento de metas coletivas previamente estabelecidas: p.ex., redução do índice de ataque pela cárie dental em crianças de 6 a 12 anos, cobertura real com cuidados básicos de $50 \%$ dos grupos prioritários da comunidade. Este adicional, que é negociado com os profissionais, técnicos, auxiliares (com o conhecimento e participação da população adscrita), não deve estar ligado aos clássicos critérios de produtividade clínica e embora dependa dos recursos orçamentários disponiveis necessita assumir valores relativos compensadores para que realmente desempenhe um papel catalizador de um desempenho funcional mais comprometido e de melhor qualidade. Uma vez estabelecido este regime, gradativamente sua importância aumenta, podendo chegar ao ponto em que os padrões sanitários e de acesso a cuidados básicos se constituam em fatores determinantes de importância real e predominante na renda mensal da equipe odontológica.

\section{: 9.5. Linhas de Estudo e Pesquisa}

Um importante conjunto de dúvidas e de pontos não suficientemente esclarecidos ou desconhecidos, persiste em relação à ação odontológica comunitária.

Dentro de cada unidade prestadora de serviços e como parte da politica de saúde bucal para o país, é preciso que seja desenvolvida uma linha sólida de estudos e pesquisas com o objetivo maior de compreender os elementos que impedem ou dificultam a 
melhoria das condições de saúde, indicando as estratégias e os meios para supera-los.

$\mathrm{Na}$ indicação de temas a estudar, feita a seguir por campo de atuação, incluem-se questões que tanto podem ser enfocadas a nível central quanto no contexto de cada município. Os sistemas locais de saúde bucal, que tem limitada disponibilidade de tempo por estarem mais envolvidos com a prestação de serviços, precisam escolher com muito apuro os assuntos que farão parte do seu universo de estudo, conferindo prioridade aos temas que tiverem interesse ou que se relacionem aos problemas vividos pela sua população adscrita.

As fronteiras entre um estudo e uma pesquisa, ou seja, entre uma análise situacional (operacional) e a investigação mais aprofundada ou a exploração de novos conhecimentos sobre os diversos aspectos do sistema de saúde, são idealmente estabelecidas por parte de cada instituição ou unidade local. 


\section{: 9.5.1. Estudos sobre Fatores Etiológicos}

(a) Padrões de consumo de açúcar, mormente nas faixas etárias de maior prioridade e nos grupos populacionais mais expostos (p.ex., crianças, adolescentes, residentes em regiões açucareiras);

(b) dinâmica de produção e comercialização de açúcar, com vistas a sugerir medidas práticas para redução do consumo;

(c) dietas com baixo teor de carboidratos cariogênicos, de formas a identificar alimentos nutricionalmente adequados, financeiramente acessiveis, de paladar e apresentação aceitáveis e de fácil acesso no comércio local;

(d) relacionamento entre o hábito de fumar e a prevalência de lesões da mucosa pré-cancerosas ou não;

\section{:: $\quad 9.5 .2$. Estudos Epidemiológicos}

(a) Identificação de razões para que os índices de ataque pela cárie dental sejam mais elevados nos estratos de baixa renda;

(b) tendências de comportamento das principais doenças orais, através de medições periódicas $\mathrm{com}$ base em indicadores selecionados (vide Título 9.2.6) aplicáveis notadamente nas cidades e regiões submetidas a métodos preventivos de massa;

(c) condicionantes da prática de extrações em populações adultas, estabelecendo diferenças por tipos de serviços ofertados (públicos, privados, empíricos, etc.) e a importância das causas econômicas e clínicas;

(d) padrões de saúde bucal na 3a. Idade, diferenciando grupos por "status" social e possibilidade de acesso a serviços segundo o grau de dependência funcional.

$\therefore$ 9.5.3. Estudos sobre o Sistema Prestador de Serviços

(a) Condicionantes sociais e econômicos da procura de serviços odontológicos;

(b) efeitos de distintas modalidades de custeio e de remuneração de serviços sobre a demanda e sobre o nível de saúde oral, com ênfase em análises da modalidade de pagamento por capitação com base no nível de saúde da população adscrita e da cobertura alcançada (remuneração adicional sobre um salário básico, conforme descrito no parágrafo final do Título 9.5);

(c) adscrição da clientela a sistemas locais de saúde, com definição de áreas geográficas de abrangência, serviços disponiveis no município ou de referência em outras localidades, custos, etc.;

(d) modelo de odontólogo familiar, com adscrição de um número determinado de famílias a um centro de saúde, a uma clínica ou a um nrnficcinnal. 
(e) participação social nas organizações locais de saúde bucal, com identificação de experiências, forma e intensidade da participação comunitária, atitudes e resistências das entidades de representação profissional;

(f) atendimento clínico, preventivo e educativo de escolares em regimes combinados com unidades dentro e fora da escola.

:: 9.5.4. Estudos sobre Prevenção

(a) Resultados da fluoretação da água e da aplicação de métodos tópicos de massa, principalmente aqueles desenvolvidos sem supervisão direta, identificando as metodologias mais adequadas de trabalho e de relacionamento com a população; Brasil;

(b) efeitos preventivos do uso de dentifricios fluoretados no

(c) efeitos da interrup̧ão de programas preventivos;

(d) experimentação de métodos alternativos de aplicação tópica de flúor a nível comunitário, utilizando por exemplo vernizes com flúor e soluçōes altamente concentradas com flúor;

(e) padrões de fluorose em populações submetidas a terapias intensivas ou à ingestão de flúor através de dois ou mais veículos.

:: 9.5.5. Educação em Saúde e Opiniões da População

(a) Utilização efetiva de métodos de auto-defesa contra as doenças bucais;

(b) resultados obtidos com os métodos educativos em uso (p.ex. proporção de pessoas que escovam corretamente e com periodicidade adequada seus dentes, que se beneficiam regularmente de cuidados preventivos, que reduzem o consumo de carboidratos cariogênicos, );

(c) pesquisas de opinião sobre os serviços de saúde existentes (qualidade, acessibilidade, serviços prestados, horários, atendimento, proteção adequada contra infeç̧ões, etc.);

(d) formas desejadas e viáveis de participação da comunidade.

$:: \quad 9.6$. Sintese e Sugestões

o conjunto de sugestões apresentado neste capítulo pode ser resumido, quanto aos seus. principais aspectos, no seguintes tópicos:

- implementação de um sistema de atendimento odontológico a partir do setor público objetivando prioritariamente reduzir a incidência da cárie dental e estruturar uma rede de prestação de serviços em quantidade suficiente e com boa qualidade à população. 
- ênfase nos sistemas locaos de saúde bucal, fundamentados na adscrição da clientela e na participação comunitária.

- identificação de prioridades clarás de atenção odontológica às comunidades, pela utilização $e$ um modelo que contemple um elenco de medidas essenciais e outro de medidas complementares.

- desenvolvimento de um programa preventivo abrangente, em relação à cárie dental, baseado principalmente na fluorentação da água de abastecimento público, na aplicação tópica de flúor em massa e com regularidade, no apoio à escovação com dentifrícios fluoretados e na redução do consumo de açúcares.

- adoção de medidas educativas em saúde oral voltadas para o uso correto de métodos preventivos da cárie dental, emprego adequado de medidas de higiene oral visando manutenção de niveis de placa bacteriana compatíveis com uma boa saúde dos tecidos periondontais, redução quantitativa do total de açúcares ingeridos e, ainda, enfatizando a conservação de dentição natural negando a prática de extrações desnecessárias.

- organização de sub-sistema de atenção a crianças e adolescentes a partir de programa com agrangência coletiva municipal, fazendo uso de "cartões de saúde bucal" como estratégia para alcançar uma gradativa universalização da cobertura.

- inclusão dos grupos mais discriminados social e economicamente, assim como dos problemas bucais de maior gravidade, no elenco de medidas essenciais.

- práticas de ações de vigilância sanitária voltadas pra o controle da qualidade dos produtos preventivos comercializados no país e da quantidade de fluoretos consumidos pela população, dando destaque para o controle do teor de flúor na água de consumo.

- efetivação de um sub-sistema nacional de vigilância epidemiológica em saúde bucal, com fundamento na realização periódica de exames em um conjunto limitado de localidade por região.

- maior profissionalização dos recursos humanos que atuam no setor público, evitando o exercício em tempo parcial, a dupla militância, os credenciamentos de profissionais que trabalham na clínica privada a multiplicidade de empregos e os baixos salários.

- intensificação do treinamento e da contratação de Técnicos de Higiene Dental e de pessoal auxiliar em geral.

- definição de diretrizes e de critérios quanto as fontes de custeio e modalidades de remuneração de serviços, preservando em primeiro lugar as ações de caráter essencial e unificando em um só conjunto programático os recursos disponiveis para cada sistema local. 
- Desenvolvimento de estudos com ênfase nos que se dedicarem ao melhor conhecimento dos fatores etiológicos das doenças orais, da epidemiológica bucal, do sistema prestador de serviços, das linhas preventivas de âmbito populacional e, ainda, dos métodos e práticas de educação em saúde oral e das opiniões da população sobre os serviços que the são ofertados. 


\section{BIBLIOGRAFIA}

001 - ABO fará coleta de água para exame de flúor. - ABO; Jornal Nacional 3 (10) mar./abr. 1991.

002 - ALBUQUERQUE, R. C. \& VILLELA, R. - A situação social no Brasil: um balanço de duas décadas. Rio de Janeiro, 1990. 49p. versão preliminar.

003 - AMERICA Latina hoy. - Panorama Suvision 3 (6): 21-30 Mayo/Ago. 1986.

004 - ANUÁRIO ESTATÍSTICO DO BRASIL, 1989. - Rio de Janeiro, Fundação IBGE, 1989.

005 - ANUÁRIO ESTATÍSTICO DO BRASIL, 1990. - Rio de Janeiro, Fundação IBGE, 1990.

006 - ARCIERI, R. M. et. alii. - Estudo comparativo da prevalência da cárie dentária após 10 anos da adição de flúor nas águas de abastecimento público de Uberlândia - MG. Revista Paulista de odontologia São Paulo. 8 (2): 46-55 mar./abr. 1986.

007 - BANCO MUNDIAL. - World development report, 1991; Challenge of Development. New York, Oxford University, Press, 1991. 290 .

008 - BARBOSA, S. N.; FREIRE, A. M.; PINTO, V. G. - Nota sobre a politica de saúde na nova república. Documento entregue ao Dr. Tancredo A. Neves. Brasilia, em 8/3/85.

009 - BARRA, Rubia Pereira. - Prevalência de cárie dentária entre dois grupos de escolares atendidos durante 4 anos através do sistema incremental, beneficiados ou não pela aplicacão tópica de flúor. Uberlândia Universidade Federal, 1990. 32p.

010 - BECKER, R. A. - Brasil: Tendências recentes das causas de mortalidade na infância. In: IBGE/UNICEF. Perfil estatístico de crianças e mães no Brasil: mortalidade infantil e saúde na década de 80 . Rio de Janeiro, IBGE, 1989 . p. 55-83.

011 - BELTRAN, E. D. \& BURT, B. A. - The pre - and posteruptive effects of fluoride in the caries decline. J. of Public Health Dentistry 48 (4): 233-240. 1988 .

012 - BHAT, Mohandas. - Periodontal health of 14-17-year-old US schoolchildren. Journal of Public Health Dentistry 51 (1): $5-11,1991$. 
013 - BIJELLA, M. F. T. B. - Comparison of dental prophylaxis and toothbrushing prior to topical APF Applications. Community Dent Oral Epidemiol 13: 208-11 Aug. 1985.

014 - BIZARRIA, Hamilton. - Desenvolvimento da economia brasileira. Brasilia, set. 1991. Informação pessoal.

015 - BOHATY B.S. et alli. - Prevalence of fluorosis-like lesions associated with topical and systemic fluoride usage in an area of optimal water fluoridation. Pediatr Dent 11:125-8, 1989.

016 - BOLETIM MENSAL DO BANCO CENTRAL DO BRASIL. - Brasilia, BACEN, 1991 .

017 - BRANDÃO, C. T. \& BRANDÃO, R. F. - Alternativas alimentares. LONDRINA, CNBB. Pastoral da criança, 1988. 51p.

018 - BRASIL. Constituição, 1988. - Constituição: República Federativa do Brasil. Brasilia, Senado Federal, 1988. 292p.

019 - BRASIL. - É o 19 em pobreza na América Latina. Folha de São Paulo, São Paulo, 23 nov. 1990. p. C-10.

020 - BRASIL. Leis, Decretos, etc. - Lei n 8080, de 19 de Setembro de 1990. Diário oficial de 20/09/1990. Dispōe sobre as condições para a promoção, proteção e recuperação da saúde, da organização e o funcionamento dos serviços correspondentes e dá outras providências.

021 - BRASIL. Leis, Decretos etc. - Lei no 8.142 de 28 de dezembro de 1990. Diário Oficial de $31 / 12 / 90$. Dispōe sobre a participação da comunidade na gestão do sistema único de saúde - SUS e sobre as transferências intergovernamentais de recursos financeiros na área da saúde e dá outras providências.

022 - BRASIL. Ministério da Educação. - A educação no Brasil na década de 80. Brasilia, 1990. 106p.

023 - BRASIL. Ministério da Educação. - Ensino de primeiro grau; taxa de sucesso. Brasilia, 1990. 26p.

024 - BRASIL. Ministério da Educação. - Estoque de profissionais do nível superior, Brasil - 1970/85. Brasilia, 1985. (Estudos Estatísticos, 2)

025 - BRASIL. Ministério da Educação. - Estoque de profissionais e número de concluintes do nível superior, Brasil 1954-87. Brasilia, out. 1990. (Estudos Estatisticos, 11).

026 - BRASIL. Ministério da Educação. - Número de alunos e de escolas de 10 grau por dependência administrativa $\epsilon$ 
região: Brasil, 1989. Brasilia, MEC/SG/Secretaria de Planejamento, 1991. Tabelas de Computador.

027 - BRASII. Ministério da Educação. - Sinopse estatística do ensino superior, 1988 a 1990. Brasilia, 1990-

028 - BRASIL. Ministério da Educação. - Sinopse regular de 10 grau.; censo educacional 1988. Brasilia, 1991.

029 - BRASII. Ministério da Educação. - Visão pánorâmica do ensino regular de 19 grau; Brasil 1979 - 1990. Brasilia, 1990.

030 - BRASIL. Ministério da Fazenda. Secretaria do Tesouro Nacional. - Balanço geral da União, 1989. Brasilia, 1990.

031 - BRASIL. Ministério da Previdência e Assistência Social \& CEPAL, Brasilia. - A politica social em tempo de crise: articulação institucional e descentralização Brasilia 1990. (Economia e Desenvolvimento, 7) Conteúdo: v.4 Brasil: indicadores sociais selecionados.

032 - BRASIL. Ministério da Previdência e Assistência Social \& Ministério da Saúde. - Programa nacional de serviços básicos de saúde - PREV/Saúde. Brasilia, 1981.

033 - BRASII. Ministério da Saúde. - Fórum internacional de saúde bucal: painéis e conferências. Campo Grande. Divisão Nacional de Saúde Bucal, Documentos Técnicos, 20. Brasilia, 1990. 150p.

034 - BRASII. Ministério da Saúde. - Levantamento epidemiológico em saúde bucal: Brasil Zona Urbana, 1986. Brasilia, Divisão Nacional de Saúde Bucal/FSESP, 1988. 137p. (Série, Estudos e Projetos, 4)

035 - BRASII. Ministério da Saúde. - Normas técnicas para controle da AIDS e outras infecçōes virais na prática odontológica. Brasilia, DNST/AIDS e DNSB, 1989. 22p.

036 - BRASIL. Ministério da Saúde. - portaria ne 22/SNVS de 24/08/89. Define normas para registro e controle de enxaguatórios bucais com flúor para uso diário e de dentifrícios com flúor. Brasilia, 24/08/89.

037 - BRASII. Ministério da Saúde. - portaria ne 184 de 9/10/1991. Tabela de procedimentos ambulatoriais de odontologia. Diário Oficial 10/10/1991.

038 - BRASIL. Ministério da Saúde. - Portaria 420/GM de 24/08/87. Aprova alterações no registro interno da SNPES criando a Divisão Nacional de Saúde Bucal. Brasilia, 1987.

039 - BRASIL. Ministério da Saúde. - portaria no 612/GM de 13/06/1989. Aprova o programa nacional de prevenção da 
cárie dental. Boletim de Serviço do Ministério da Saúde, 29 de 23/06/89.

040 - BRASIL. Ministério da Saúde. - Portaria ne 613/GM de 13/06/1989. Aprova a política nacional de saúde bucal. Boletim de Serviço do Ministério da Saúde, 29 de 3/06/89.

041 - BRASIL. Ministério da saúde. - Portaria ne 614/GM de 13/06/1989. Institui grupo de especialistas em prevenção de doenças bucais. Boletim de Serviço do Ministério da Saúde, 29 de 23/06/89.

042 - BRASIL. Ministério da Saúde. - Portaria ne 615/GM de 13/06/1989. Institui o dia nacional de prevenção das doenças bucais. Boletim de Serviço do Ministério da Saúde, 29. de $30 / 06 / 89$.

043 - BRASIL. Ministério da Saúde. - Portaria no 616/GM de 13/06/1989. Institui as coordenadorias macro-regionais de odontologia. Boletim de Serviço do Ministério da Saúde, 29 de $23 / 06 / 89$.

044 - BRASII. Ministério da Saúde. - Coordenação de orçamento e finanças - Recursos aplicados pelo Ministério da Saúde. 1987 e 1990. Brasilia, jun. 1990.

045 - BRASIL. Ministério da Saúde. Divisão Nacional de Saúde Bucal. - Aplicação tópica de flúor com gel fluoretado: Normas Técnicas. Brasilia, 1989. 27p. (Documentos Técnicos, 4).

046 - BRASII. Ministério da Saúde. Divisão Nacional de Saúde Bucal. - Informações básicas para o planejamento em odontologia Brasilia, 1989. (Doc. Técnico, 06)

047 - BRASIL. Ministério da Saúde. Divisão Nacional de Saúde Bucal. - Informações básicas para o planejamento em odontologia: resultados por estado, 1989. Brasilia, 1990. Tabelas.

048 - BRASIL. Ministério da Saúde. Divisão Nacional de Saúde Bucal. - Perfil da odontologia brasileira. Brasilia, 1988. (Documento Técnico, 1/88).

049 - BRASIL. Ministério da Saúde. Divisão Nacional de Saúde Bucal. - Política nacional de saúde bucal; princípios, objetivos, prioridades. Brasilia, 1989. 23p.

050 - BRASIL. Ministério da Saúde. Divisão Nacional de Saúde Bucal. - PRECAD; implementação do sub-programa II - aplicação tópica de fluor - gel. Brasilia, 1989.

051 - BRASIL. Ministério da Saúde. Divisão Nacional de Saúde Bucal. - Programa nacional de prevenção da cárie dental - PRECAD. Brasilia, 1989. (Documento Técnico, 08). 
052 - BRASIL. Ministério da Saúde. Divisão Nacional de Saúde Bucal. - Relação de localidades com fluoretação de água de consumo público. Brasilia, 1989.

053 - BRASIL. Ministério da Saúde. Secretaria Nacional de Assistência à Saúde. - Portaria ne 15, 16, 17, 18, 19, 20. de 8 de Janeiro de 1991. Saúde em Debate 31:5 - 6 mar. 1991 .

054 - BRASIL. Presidência. Secretaria de Planejamento e Coordenação.Secretaria de Orçamento e Finanças. Orçamento da União. Exercício financeiro de 1990. Lei ne 7990 de 31 de janeiro de 1990. Brasilia, 1990.

055 - BRYAN, E.T. \& WILLIAMS, J.E. - The cariostatic effectiveness of a phosphate-fluoride gel administered annually to schoolchildren: I. The results of the first year. J Public Health Dent 28:182-5, 1968.

056 - BUENDIA, Osvaldo C. - Prevenção da cárie dentária através de bochechos fluorados. Trab. apres. no congresso de odontologia do Rio Grande do Norte, 3. Natal, 1980. $6 f$. mimeo.

057 - BURT, B. A. - Public health implications of recent research in periodontal diseases. Journal of Public Health Dentistry. 48 (4): 252-256, 1988.

058 - BUTLER W. J.; SEGRETO V. and COLLINS E. - Prevalence of dental mottling in school-aged lifetime residents of 16 Texas communities. Am J Public Health 75:1408-12, 1985.

059 - BUTTNER, Martin. - Switzerland's approach to preventive dentistry. Basel, 1990

060 - CANADÁ. Department of National Health and Welfare. Preventive dental services. 2. ed. Ottawa, 1988. 229p.

061 - CAUDURO NETO, Ricardo. - Numero de cirurgiōes dentistas por estado segundo o sexo. Brasil 1989. Porto Alegre, 1991. Informação pessoal.

062 - CARVALHo, Gilson de Cassia Marques de. - o caos no financiamento da saúde... no fundo do poço. São José dos Campos, Secretaria Municipal de Saúde, 1990. 14p.

063 - CEPAL, Santiago. - Magnitude de la pobreza en America Latina en los años ochenta. Notas Sobre la Economia y el Desarrollo. Santiago, 4947495 jul./ago. 1990.

064 - COBB H.B; ROZIER, R.G. and BAWDEN J.W. - A clinical study of the caries preventive effects of an APF solution and APF thixotropic-gel. Pediatr. Dent $2: 253-6,1980$. 
065 - COLETÂNEA da legislação básica (SUDS). Brasilia, MPAS, 1989. $165 p$.

066 - CONFERÊNCIA NACIONAL DE SAÚDE. 8. Brasilia, 1987. Anais. Brasilia, Ministério da Sáude, 1987.

067 - CONFERÊNCIA NACIONAL DE SAúDE BUCAL, 1. Brasilia, 1986. Resoluções. Brasilia, 1986.

068 - CONJUNTURA estatística. - Conjuntura Econômica. Rio de Janeiro 44 (5): 47-78 maio 1990 .

069 - CONJUNTURA estatística. Conjuntura Econômica. Rio de Janeiro, 45 (66): 49-80 junho 1991 .

070 - CONSELHO FEDERAL DE ODONTOLOGIA. - Distribuição dos Cirurgiões-Dentistas por estado. Rio de Janeiro, 1990. Tabelas.

071 - CORDEIRO, H. - Controvérsias no Financiamento do SUS. Saúde em Debate 31: 19-24 mar. 1991.

072 - CORDON, P., Jorge. - Características do Cirurgião Dentista no Distrito Federal. Divulgação em Saúde para Debate. 6: 1926 out. 1991.

073 - CRIANÇAS e adolescentes: indicadores sociais. Rio de Janeiro, IBGE, 1989. V.3.

074 - CURY, J. A. - Fluorterapia. S. L. ABOPREV, 1991. (Biblioteca Científica, 4).

075 - DE PAOLA, P. F. - Reaction paper: the use of topical and systemic fluorides in the present era. Journal of Public Health Dentistry. 51 (1): 48-52.

076 - DISTRITO FEDERAL. Secretaria de Educação e Cultura. Projeto Saúde Bucal, Programa Integrado de Saúde Escolar - PISE. Brasilia, 1977. 36p.

077 - EKSTRAND, J. - Pharmacokinetic aspects of topical fluorides. J. Dent. Res. 66(5): 1061-1065, May 1987.

078 - ELDERTON, R. J. - Evolution in dental care. Bristol, Clinical Press Lim., 1990. 107p.

079 - ENCONTRO NACIONAL DE ADMINISTRADORES E TÉCNICOS DO SERVIÇO PÚBLICO ODONTOLÓGICO. ENATESPO, 8. São Paulo, 1991. Documento final. São Paulo, 1991. 5p.

080 - ENGLANDER, H. R., et alii. - Incremental rates of dental caries after repeated topical sodium fluoride applications in children with lifelong consumption of fluoridated water. J. Amer. Dent. Assoc. 82:345-358, 1971. 
081 - ESPECIAL dois anos de governo: rejeição a Collor chega a 48\%. Folha de São Paulo. Caderno Especial 8p. março, 15. 1992

082 - ETTINGER, R. et alii. - Oral health needs of the elderly. London, FDI, 1991. 27p.

083 - FAO, Rome. - Production yearbook. Roma, 1988. v.42

084 - FEDERATION DENTAIRE INTERNATIONALE. FDI. - Basic facts, 1990. Dentistry Around the World. London, 1990?

085 - FERREIRA, Renato. - Recursos humanos e oferta de servicos odontológicos em Minas Gerais. Belo Horizonte, nov. 1991. Informação pessoal.

086 - FIORES - DE JACOBY, S. et alii. - Periodontal Conditions in Rio de Janeiro city (Brazil) using the CPITN. Community Dent Oral Epidemiol 19:127-8, 1991.

087 - FRANDSEN, A. Ed. - Public health aspects of periodontal disease. Chicago, Quintessence Public. 1984. 255p. Proceedings of a Workshop Health in Copenhagen, Denmark. Dec., 1982.

088 - FREIRE, Paulo da S. - Parecer sobre o programa nacional de prevenção da cárie dental para o conselho Federal de odontologia. Rio de Janeiro, 1990. mimeo.

089 - FUNDAÇÃO SERVIÇOS DE SAÚDE PÚBLICA. - Prevenção da cárie dental pela auto-aplicaça de bochechos fluorados. Brasilia, 1980. 16p.

090 - GARCIA, I. Caries incidence and costs of prevention. programs. Journal of Public Health Dentistry $49(5):$ 259$271,1989$. Special Issue.

091 - GIBSON, G. B.; RICHARDSON, A. S. and WALDMAN, R. - The effectiveness of a chemically polymerized sealant in preventing occlusal caries: Five year results. Pediatr Dent 4: 309-310, 1982 .

092 - GIFT, H. C. - Prevention of Oral Diseases and Oral Health Promotion. Dentistry 1:337-347, 1991 .

093 - GRABER, T. M. \& SWAIN, B. F. - Ortodoncia: Principios Generales y Tecnicas. B. Aires., Ed. Medica Panamericana, 1989. 1064p.

094 - GRILICHES, A. \& INTRILIGATOR, M. - Handbook of Econometrics. - Amsterdam, North Holland, 1983. v.1

095 - GRINPLASTCH, B. S. - Fluoretação da água no Brasil. Bol. Ofic. Sanit. Panamer., 76: 321-30. 1974. 
096 - GROENEVELD, A. et alii. - Fluoride in caries prevention: is the effect pre- or post-eruptive? J. Dent Res. 69:751755, Feb., 1990. Special issue.

097 - GUSSO, Divonzir A. - A escola de 19 grau e sistema para atenção odontológica no Brasil. In: Forum internacional de saúde bucal, painéis e conferências. Campo Grande. Ministério da Saúde. Divisão Nacional de Saúde Bucal. Documento técnico 20. Brasília, 1990. pp. 85-89.

098 - GUSSO, Divonzir A. \& GEVAERD, S. - Atenção odontológica para escolares no Brasil: demandas sociais, politicas públicas e desafios. Relatório de consultoria para a Divisão Nacional de Saúde Bucal, Ministério da Saúde. Brasilia, 1989. 46p. mimeo.

099 - HEATON, R. W. et alii. - Açúcares: debate atual e ação futura. S.1, ABOPREV, 1991. 26p. (Biblioteca Cientifica, 2)

100 - HEIFETZ, S. B., et alii. - Combined anticariogenic effect of fluoride gel-trays and fluoride mouthrinsing in an optimally fluoridated community. Clin. Prev. Dent. 1: 21$23,28,1979$.

101 - HOELZ, G. \& KLAFKE, I. - Experiência odontológica de Santa Cruz do Sul, RS. Divulgação em saúde para debate $6: 73-75$ out. 1991.

102 - HOROWITZ, H.S. \& DOYLE, J. - The effect on dental caries of topically applied acidulated phosphate-fluoride: results after three years. J. Am Dent ASSOC 82:359-65, 1971

103 - HOUPT, M.; KOENIGSBERG, S. and SHEY, Z. - The effect of prior toothcleaning on the efficacy of topical fluoride treatment: two-year results. Clin. Prev. Dent. 5: 8-10, 1983

104 - HOUPT, M. \& SHEY, Z. - The effectiveness of fissure sealant after six years. Pediatr. Dent 5: 104-106, 1983.

105 - IBGE. Contas nacionais do Brasil 1980/1990. Rio de Janeiro, jul. 1991 .

106 - IBGE. - Estatísticas da saúde: assistência médico-sanitária, 1985. Rio de Janeiro, 1988. v. 10.

107 - IBGE. - Pesquisa de orçamentos familiares, 1987/88. Rio de Janeiro, 1991 .

108 - IBGE. - Pesquisa nacional por amostra de domicílio, PNAD. 1981. Rio de Janeiro, 1983 
109 - IBGE. - Pesquisa nacional por amostra de domicílio, PNAD. 1988. Rio de Janeiro, 1990.

110 - IBGE. - Pesquisa nacional por amostra de domicílio, PNAD. 1989. Rio de Janeiro, 1991.

111 - IBGE. - Síntese de indicadores da pesquisa básica da PNAD de 1981 a 1989. Rio de Janeiro 1990. 90p.

112 - IBGE \& UNICEF.- Perfil estatístisco de crianças e mães no Brasil; mortalidade infantil nos anos 80 . Rio de Janeiro, 1989. 130p.

113 - INAMPS. - Balanco geral 1980 a 1989. Rio de Janeiro, 1990114 - INAMPS. - Gestão do INAMPS. 1990. QDD. Brasília, 1990. Anexo.

115 - INAMPS. - Norma operacional básica n 1/91. Saúde em Debate 31: 6 mar. 1991.

116 - INAMPS- Programa de reorientação da assistência odontológica. Rio de Janeiro MPAS, 1983. 50p.

117 - INAMPS. - Resolução ñ 258, de 7 de Janeiro de 1991. Saúde em Debate 31: 6 mar. 1991 .

118 - INAMPS. Coordenadoria de Supervisão e Auditoria de odontologia. - Relatório sistemático de recursos odontológicos próprios do Brasil. Sistema de Recursos odontológicos. Brasilia, 1990.

119 - INAMPS. Diretoria de Planejamento. - Servicos produzidos e gastos, tabelas, 1981/1989. Brasilia, 1990.

120 - INAMPS em Dados 1980 a 1989. Brasília, 1990.

121 - INAN. - Pesquisa nacional sobre saúde e nutrição: PNSN 1989. Arquivo dos dados da pesquisa. Brasilia INAN/FIBGE/IPEA, 1990. mimeo.

122 - INAN. - Pesquisa nacional sobre saúde e nutrição: resultados preliminares Brasilia, INAN/FIBGE/IPEA, 1990. 35p.

123 - INDICADORES SOciais; assistência à saúde. Previdência em dados. Brasília, DATAPREV, 6 (i): 44-61 jan./mar. 1991.

124 - INDICADORES SOciais; assistência médica. Previdência em dados. Brasilia, DATAPREV, 4 (2): $30 / 38$ abr./jun. 1989.

125 - INGRAHAM, R.Q. \& WILIIAMS, J.E. - An evaluation of the utility of application and cariostatic effectiveness of phosphate-fluoride in solutions and gel states. J. Tenn. Dent. Assoc. 50 (Jan.) 5:12, 1979. 
126 - INTERNATIONAL SUGAR ORGANIZATION. - Sugar yearbook, 1989. 43 ed. London, 1990. 342p.

127 - IPEA. - Estimativas anuais de população (1980-2010). Regiões brasileiras versus situação de domicílio. Brasília. IPEA/CPS. maio, 1991. Doc. Avulso, 2.

128 - IPEA. - Estimativas da população brasileira por idades exatas para 1989, tabelas. IPEA/CPS. agosto, 1992.

129 - IPEA - IPLAN/CNRH. - Nota sobre programa na area de odontologia. Brasilia, ago. 1977. cópia xerox.

130 - IPEA/IPLAN \& UNICEF. A criança no Brasil: O Que Fazer? Brasilia, 1990. 83p. (Acompanhamento de Políticas Públicas, 23).

131 - IUPERJ. Que Brasil é Este? Manual de indicadores políticos e sociais. Rio de Janeiro, Instituto Universitário de Pesquisa do Rio de Janeiro, 1990.

132 - JENKINS G.N. - Recent changes in dental caries. Br. Med. J. (Clin Res) 291:1297-8, 1985.

133 - LARSEN, M. J. et. alii. - Prevalence of dental fluorosis after fluoride-gel treatments in a low-floride Area. J. Dent Res. 64 (8): 1076-1078, Aug. 1985.

134 - LATIN American dental survey. Panorama Suvision 1 (1): 15-36. 1986. Sept./Dec., 1986.

135 - LECOMPTE, E. J. - Clinical application of topical fluoride products: risks, benefits, and recommendations. J. Dent. Res. 66 (5): 1066-1071 May 1987.

136 - LEMOS, M. M. V. - Sistema Incremental; a necessidade de tratamento de crianças em idade escolar. Uberlândia, Universidade Federal, 1991. 23p.

137 - LEVERETT, D. H. - Appropriate uses of systemic fluoride: considerations for the $90 \mathrm{~s}$. Journal of Public Health Dentistry 51 (1): 42-47, 1991 .

138 - LIMA, Mônica, O. P. et alii. - Estudo das condições de saúde bucal dos trabalhadores da construção civil. Brasilia, SESI. Depto Nacional. 1991. 42p. mimeo. "Projeto SESI na Construção Civil - Operação de Serviços em Canteiros de Obra".

139 - LOPES, \& GOTTSCHALK. - Recessão, pobreza e familia, a década pior do que perdida. São Paulo em Perspectiva, 4 (1): 102$109 \mathrm{Jan} / \mathrm{mar} .1990$

140 - LOUREIRO, Carlos. - Sistema de inversão de atenção odontológica. Belo Horizonte, out. 1991. Palestra 
proferida na semana acadêmica da UFMG. Faculdade de Odontologia.

141 - LOURO FILHO, Paulo \& MAYER, M. D. A. - Conceito de risco e avaliação de risco de cárie. s.1., ABOPREV, s.d. 11p. (Biblioteca Científica, 1)

142 - MC DONALD, R. E. \& AVERY, D. R. - Odontopediatria. Rio de Janeiro. Guanabara-Koogan. 59 ed. 1991. 598p.

143 - MAC-ENTEE, M. \& SCULLY, C. - Oral disorders and treatment implications in people over 75 Years. Community Dent Oral Epidemiol 16: 271-3, 1988 .

144 - MANSBRIDGE, J. N. \& BROWN, M. D. - Changes in dental caries prevalence in Edinburg children over three decades. Community Dent Health 2: 3-13, 1985.

145 - MARTHALER, T. M. - Cariostatic efficacy of the combined use of fluorides. J. Dent. Res. 69: 797-800, Feb., 1990. Special Issue.

146 - MARTINS, Claudio B. - Recursos humanos e oferta de servicos odontológicos na Fundação Hospitalar do Distrito Federal. Brasilia, jul. 1990. Informação pessoal.

147 - MEDICI, A. C. - o gasto com saúde nos anos 80 . In: IBGE/UNICEF. Perfil estatístico de criancas e mães no Brasil; mortalidade infantil e saúde na década de 80 . Rio de Janeiro, IBGE. 1989. P. 109-129.

148 - MEDICI, A. C. - Novas regras para o financiamento do setor saúde em 1991. Saúde em Debate 31: 25-30 mar. 1991.

149 - MEDICI, A. C. - Perspectivas do financiamento à saúde no governo Collor de Mello. Rio de Janeiro, 1991. 65p.

150 - MERTZ-FAIRHUST, E. J. et alii. - A comparative clinical study of two pit and fissure sealants: six-year results in Augusta, Georgia. J. Amer. Dent. Assoc. 105: 237-239, 1982 .

151 - MERTZ-FAIRHUST, E. J. et alii. - A comparative clinical study of two pit and fissure sealants: 7-year results in Augusta, Georgia. J. Amer. Dent. Assoc. 199: 255-255, 1984 .

152 - MEURMAN, J. H. HELMINEM, S. K. J. and LUOMA, H. -Caries reduction over 5 years from a single application of fissure sealant. Scand. J. Dent. Res. 86: 153-156, 1978.

153 - MEZADRI, Telmo \& CAETANo, J. Carlos. - Recursos humanos e oferta de serviços odontológicos em Santa Catarina. Florianópolis nov. 1991. Informação pessoal. 
154 - MINAS GERAIS. Secretaria de Estado da Saúde. - Dados Saúde Oral. Belo Horizonte, SUDS, 1989.

155 - MINAS GERAIS. Secretaria de Estado da Saúde. Recursos humanos do programa de saúde bucal do SUS-MG por categoria profissional e instituição, 1990. Belo Horizonte, 1991. Tabelas.

156 - MONITORAMENTO do Flúor. - Coleta das amostras. Jornal da APCD, nov. 1991 . P. 13.

157 - MONTENEGRO, J. L. \& OLIVEIRA, L. L. A. - Indicadores de eficiência do ensino fundamental no Brasil. Década de 80 . Brasilia. 1991. Tabelas.

158 - MONTENEGRO, J. L. \& OLIVEIRA, L. L. A. - Modelos de análise do fluxo escolar. Brasilia, MEC/SAG, 1991. 45p.

159. - NAISBITT, J. \& ABURDENE, P. - Megatrends 2000; dez novas tendências de transformação da sociedade nos anos 90 . São Paulo, AMANA-KEY, 1990. 461p.

160 - NEWBRUN, Ernest. - Cariologia. 2. ed. rev. São Paulo, 1988.

161 - NEWBRUN, Ernest. - Topical fluoride therapy; discussion of some aspects of toxicology, safety, and efficacy. J. Dent. Res. 66(5): 1084-1086, May 1987.

162 - NOTÍCIAS Sobre a Crise no Setor Saúde. O Estado de São Paulo. $1990-16$ a $18,20,22$ a 25,29 e 30 maio $1990-2,4,7$, $11,13,14,15$, setembro

163 - NOTÍCIAS Sobre a Crise no Setor Saúde. Jornal do Brasil.

$1990-7,12,18,23$ e 28 abril1990 - 4, 5, 6, 8 a 11, 13, 14, 25, maio1990 - 6, 19, 27 julho1991 - 10 fevereiro, 29 de setembro, 19 dezembro.

164 - NOVO MÉTODO para o Gel: Uma aplicação a cada 15 segundos. Odonto/Notícias ne 50, 1991. p.12:

165 - ODONTOLOGIA no plano de saúde do governo Collor.- Jornal da APCD, jun. 1990. p.2

166 - ORGANIZAÇÃO PANAMERICANA DA SAÚDE. - Desarrollo y fortalecimiento de los sistemas locales de salud: la administración estratégica; HSD/SILOS-2. Washington, 1992. $160 \mathrm{p}$. .

167 - ORGANIZAÇÃO PANAMERICANA DA SAÚDE. - Desarrollo y fortalecimiento de los sistemas locales de salud: la participación social; HSD/SILOS-3. Washington, 1990. 38p.

168 - ORGANIZAÇÃO PANAMERICANA DE SAÚDE. - Engineering manual on salt fluoridation; ORH. 84. Washington, 1987. 66p. 
169 - PARANÁ. Secretaria de Estado da Saúde. - Odontologia nos serviços públicos do Paraná. Depte de Serviços de Saúde odontológicos. Curitiba, fev. 1991. 25p. mimeo.

170 - PASCHOAL, A.D. - Experiência de saúde bucal nos municípios do SUDS. Divulgação em saúde para debate 6: 61-64 out. 1991.

171 - PEREIRA, S. - Serviços odontológicos no SESC (Serviço Social do Comércio). Brasilia, 1992. mimeo.

172 - PILOT, T. \& BARMES, D. E. - An update on periodontal. contitions in adults, measured by CPITN. International Dental Journal 37:169-172, 1987.

173 - PILOT, T. et alii. - Periodontal conditions in adolescents, 15-19 years of age: an overview of CPITN data in the WHO GLOBAL ORAL DATA BANK. Community Dent Oral Epidemiol $15: 336-338,1987$.

174 - PINTO, Ilza. L. - Prevenção da cárie dental com aplicações topicas de flúor-fosfato acidulado: resultados após 1 ano. Brasília, 1992 (a publicar).

175 - PINTO, Ilza. L. - Recursos humanos e ofertas de serviços odontológicos na Fundação Educacional do Distrito Federal. Brasília, jul. 1990. Informação pessoal.

176 - PINTO, Vitor Gomes. - Atenção odontológica à população carente. Brasília, out. 1981. "Documento encaminhado ao Conselho Federal de Odontologia para atender resoluçōes da portaria CFO-62 de 03/04/1981.

177 - PINTO, Vitor Gomes. - Discussão sobre o sistema único de saúde e suas perspectivas. Brasília, IPEA-CPS, 1990.

178 - PINTO, Vitor Gomes. - Relacionamento entre padrões de doenças e serviços de atenção odontológica. Rev. Saúde Púb. São Paulo 23 (6): 509-514, 1989.

179 - PINTO, Vitor Gomes. - Saúde bucal no Brasil. Rev. Saúde Pub. São Paulo, 17:316-327, 1983.

180 - PINTO, Vitor Gomes. - Saúde bucal, odontologia social e preventiva. 2.ed. São Paulo, Ed. Santos, 1990. 415p.

181 - PINTO, Vitor Gomes. - Saúde Bucal, panorama internacional. Brasília, Ministério da Saúde. Divisão Nacional de Saúde Bucal, 1990. 285p.

182 - PINTO, Vitor Gomes. \& VIANNA, Solon Magalhães. - Ações de odontologia no PIASS: documento preliminar. Brasilia, 22/8/77. cópia xerox. 
183 - PIRES, Fernando M. - Recursos humanos e oferta de serviços odontológicos no Rio Grande do Sul. Porto Alegre, nov. 1991. Informação pessoal.

184 - PNUD. Desarrollo humano: Informe 1991. New York. Programa de las Naciones Unidas para el Desarrollo, 1991. 280p. + tabs.

185 - PNUD. Human development report, 1990. New York. Programa de las Naciones Unidas para el Desarrollo, 1990. 189p.

186 - PROESA. Programa Odontológico Escolar de Saúde. Porto Alegre, Secretaria Municipal de Saúde e Serviço Social - Divisão de Saúde Pública - Núcleo de Odontologia Sanitária, 1988. Doc. 2 .

187 - PROGRAMA NACIONAL DE ALIMENTAÇÃO E NUTRIÇÃO. PRONAN III: Intervenções nutricionais complementares, 5 . Cárie Dental. Brasilia, 1981. mimeo.

188 - PROGRAMA Nacional de Fluoretação do Sal. - Jornal da APCD, março 1991 . p. 18.

189 - PROGRAMA NACIONAL DE SERVIÇOS BÁSICOS DE SAÚDE. PREV/SaúdeOdontologia. Brasília, 10/06/1980. Versão primeira.

190 - RENSON, C. E. et alii. - Changing patterns of oral health and implications for oral health manpower: part I (Report of a working group convened jointly by the Federation Dentaire Internationale and the World Health Organization). Int. Dent J. 35: 235-251, 1985 .

191 - RESULTS of the Workshop. Michigan. Journal of Public Health Dentistry 49 (5): 331-377, 1989. Special Issue.

192 - REUNION DE EXPERTOS SOBRE FLUORURACIÓN Y YODACIÓN DE LA SAL DE CONSUMO HUMANO, 1. 1986. Informe final Guatemala, 1986 $451 \mathrm{p}$.

193 - RICHARDSON, B. A., SMITH, D. C. and HARGREAVES J. A. - A 5year clinical evaluation of the effectiveness of a fissure sealant in mentally retarded Canadian children. Comm Dent Oral Epid 9: 170-174, 1981 .

194 - RIPA, Louis W. - A critique of topical fluoride methods. (Dentifrices, mouthrinses, operator, and self-applied gels) in an era of decreased caries and increased fluorosis prevalence. Journal of Public Helth Dentistry 51 (1) : 23-41, 1991 .

195 - RIPA, Louis W. - An evaluation of the use of professional (operator-applied) topical fluorides. J. Dent. Res. v. 69: 786-796 feb. 1990. Special Issue. 
196 - RIPA, Louis W. - Need for prior toothecleaning when performing a profissional topical fluoride application: review and recommendations for change. JADA 109;281-285 Aug. 1984 .

197 - RIPA, Louis W. - Review of the anticaries effectiveness of professionally applied and self applied topical fluoride gels. Journal of Public Health Dentistry 49(5): 297-309, 1989. Special Issue.

198 - RIPA, Louis W. - Topical fluorides: a discussion of risks and benefits. J. Dent. Res. 66(5) : 1079-1083, May 1987.

199 - ROCK. W. P. - The effectiveness of fissure sealant resins. I Dent Educ 48 (Suppl.)

200 - RODRIGUES NETO, Eleutério. - Os caminhos do sistema único de saúde no Brasil; algumas considerações e propostas. Brasilia, UnB/IPEA, $199065 \mathrm{p}$.

201 - ROSA, Antonio F. Galvão. - Recursos humanos e oferta de serviços odontológicos em São Paulo. São Paulo, nov. 1991. Tabelas. Informação pessoal.

202 - ROSA, Antonio F. Galvão \& CAUDURO NETO, Ricardo. - Custos em odontologia: análise dos custos de um serviço odontológico do setor público. Porto Alegre, Revista Gaúcha de Odontologia. 33 (3): 242-243 jul./set. 1985

203 - ROSA, Antonio F. Galvão.; IIA NETO, J.; SERIO, H. B. Avaliação da assistência odontológica no sistema local de saúde de São José dos Campos, SP. Divulgação em saúde para debate 6: 55-61 out. 1991 .

204 - ROSA, A. F. G. et alii. - Condições de saúde oral em pessoas de 60 anos ou mais no municipio de são Paulo. S.1., 1992. (a publicar).

205 - SABOIA, J. L. M. \& TOLIPAN, R. M. L. - A estrutura do emprego industrial no Brasil e a recessão dos anos 80 . Rio de Janeiro, IPEA/INPES, 1986. 72p. (IPEA/INPES. Estudos de Política Industrial e Comércio, 5)

206 - SALVATORE, Dominick. - Estatística e econometria. São Paulo McGraw-Hill do Brasil, 1982.262p.

207 - SÃO JOSÉ DOS CAMPOS. Secretaria Municipal de Saúde. - Modelo assistencial em odontologia. São José dos Campos, 1990. $21 \mathrm{p}$.

208 - SÃO PAULO - Secretaria de Estado da Saúde \& Secretaria Municipal de Saúde. - Sobre a oportunidade da fluoretação do sal: a modernidade do atraso. Nota, fev.1991. São Paulo, 1991.9p. 
209 - SÃO PAULO - Secretaria Municipal de Saúde. - Implantação do sistema de vigilância sanitária da fluoretação de águas de abastecimento público no município de são paulo, relatório anual. São Paulo, 1991.

210 - SÃO PAULO. Secretaria Municipal de Saúde. - Sistema municipal de vigilância sanitária da fluoretaçăo de águas de abastecimento público. Relátorio semestral, jan.7jun. 1991. São Paulo 1991. 6p.

211 - SATo, Sadakatsu. - Aspectos preventivos do desenvolvimento da dentição permanente. Manual ilustrado. São Paulo, Ed. Santos, 1991. 100p.

212 - SAÚDE vai fluoretar sal de cozinha. Correio Brasiliense 30/09/1990. p.14.

213 - SCHNEIDER FILHO, D. A. - Construindo a saúde bucal coletiva no município de são Paulo. Divulgação em Saúde para Debate, 6: 76:78 out. 1991 .

214 - SESC/DF. - Recursos humanos em odontologia no SESC: Brasil 1989/90. Brasilia, 1991. Tabelas.

215 - SESI. Departamento Nacional. - Manual de formação do técnico em higiene dental. Brasilia, 1986. 171p.

216 - SESI. Departamento Nacional. - Programa nacional de odontologia social - PNOS. Brasilia, 1990.

217 - SESI. Departamento Nacional. - Sinopse estatística do SESI. Brasilia, 1991. 305p.

218 - SHEIHAM, A. \& BARMES, D. E. - The goals and strategies of community dentistry in developing countries. In: Systematized Prevention of Oral Disease: Theory and practice: Florida. CRC Press, 1986. Cap. 15.

219 - SIIVA, Milton F. A. - o problema da fluoretação do sal no Brasil. Documento final de consultoria à Divisão Nacional de Saúde Bucal. Maceió, set. 1989. 6p. mimeo.

220 - SILVEIRA, W. - Recife é a 4 a pior cidade do mundo, diz estudo. Folha de São Paulo. São Paulo, 20 nov. 1990 p.D-5

221 - SIMÕES, C. C. - Novas estimativas da mortalidade infantil 1980/1987. In: IBGE/UNICEF. Perfil estatístico de crianças e mães no Brasil: mortalidade infantil e saúde na década de 80. Rio de Janeiro, IBGE, 1989. p.14-48

222 - SOUzA, Geraldo da Silva e,. - Modelo para projeção de indicadores de saúde bucal. Brasilia, 1991 - mimeo.

222 - SOUZA, Wilkens de 0. - Recursos humanos em odontologia na Fundação SESP; 1989/90. Rio de Janeiro, nov. 1991. Informação pessoal. 
223 - SPAK, C. J. et. alii. - The tissue reaction of human gastric mucosa after fluoride ingestion. Caries Res. 23 (2): 100, 1989.

224 - SREEBNY, Leo M. - Sugar consumption, sugar availability and dental caries. Community Dent. Oral Epidemiol., 10: 1-7. 1982 .

225 - STATISTICAL Bulletin. London, International Sugar Organization, 50 (8) aug. 1991.

226 - UBERIÂNDIA. SECRETARIA MUNICIPAL DE SAÚDE. Análise dos serviços odontológicos municipais. Uberlândia, 1991.

227 - VIANNA, S. M. \& PINTO, V. G. - Programa de fluoretação da áqua de abastecimento público. Brasilia, IPEA/IPLAN-CNRH, 1983. 18p. (Documento de Trabalho, 28).

228 - VIANNA, S. M. \& PINTO, V. G. - A responsabilidade do Ministério da Saúde na prevenção e tratamento das doenças bucais. Brasilia, jul. 1977. Cópia xerox. "Documento elaborado para o MS-DNDCD/SNPES.

229 - VIANNA, S. M.; PIOLA, S. F. et PINTO V. G. - Programa de saúde escolar. Brasília, IPEA/IPLAN. CNRH, $1983.21 \mathrm{P}$. (Doc. de Trabalho, 25.)

230 - VIANNA, S. M. et alii. - O financiamento da descentralização dos serviços de saúde: critérios para transferência de recursos federais para estados e municípios. Brasilia, IPEA, abr. 1991. 67p. (Documento de Política 3).

231 - VIEGAS, Yvette \& VIEGAS, Alfredo Reis. - Análise dos dados de prevalência da cárie dental na cidade de Barretos,SP,Brasil, depois de dez anos de fluoretação da água de abastecimento público. Rev. Saúde Públ. São Paulo, $19(4): 287-99,1985$.

232 - WORLD HEALTH ORGANIZATION. - Oral health global indicators for 2.000. DMFT -3 at 12 years. Genebra, May. 1989. 19p.

233 - WORLD HEALTH ORGANIZATION. Oral health global indicator for 2.000. DMFT - 3 at 12 years. Genebra, May 1990. 19p. 
$1 \mathrm{~A}$

$A N E X O S$ 


\section{$A N E X O I$}

CRITÉRIOS PARA DEFINIÇÃO DE NÚMERO DE CIRURGIÕES-DENTISTAS E POSTOS DE TRABALHO 


\section{A) TABELA 13}

Os dados são todos provenientes do $\operatorname{INAMPS}(118,119,120)$.

Referem-se ao número de Cirurgiōes-Dentistas nas colunas dedicadas aos Serviços Próprios e às Pessoas Físicas Credenciadas. Esta última corresponde aos profissionais que, em seus consultórios particulares, atendem pacientes encaminhados pela previdência social, obedecendo a condiçōes pré-estabelecidas quanto ao tipo de serviços e aos preços. Com exceção dos próprios, todos os demais enquadram-se como modalidades indiretas de prestação de serviços à população.

Nas colunas relativas a Credenciados (pessoa jurídica), órgãos públicos, Sindicatos, Entidades Filantrópicas, Faculdades de Odontologia e Hospitais Universitários, os números referem-se aos contratos ou convếnios firmados com o INAMPS. Em cada contrato ou convênio podem trabalhar dois ou mais profissionais.

As Pessoas Jurídicas Credenciadas são empresas de grupo que contratam odontólogos ou associações de profissionais, sempre com personalidade jurídica, que firmam um contrato com a previdência para atender segundo regras gerais similares às das pessoas físicas.

Os órgãos Públicos sob contrato incluem Secretarias Estaduais e Municipais de Saúde e Educação, organismos federais e uma variedade de instituições menos representativas nas tres esferas de governo.

Os Sindicatos tanto podem ser patronais como de trabalhadores, urbanos ou rurais.

As Entidades: Filantrópicas, congregam instituiçōes de benemerência e associações variadas que não têm 0 lucro como finalidade, tendo esta condição legalmente reconhecida pelo governo.

As Faculdades de Odontologia e os Hospitais Universitários ou de Ensino diferenciam-se dos órgãos públicos por receberem por produção como as pessoas, empresas e entidades privadas, e e por terem que cumprir algumas exigências contratuais como é o caso da implantação de clínicas externas ("extra-muros") para atendimento de pacientes da comunidade. 


\section{B) TABELA 15}

A Tabela refere-se a postos de trabalho ocupados e não a número de Cirurgiōes-Dentistas. Esta distinção é fundamental porque um mesmo profissional pode ocupar dois ou mais postos, além de que a informação sobre CDs empregadós ou só em atividade liberal não está disponível.

Estão incluidos tanto o pessoal em atividade clínica quanto em tarefas administrativas, de direção e outras.

o número de horas significa o tempo contratado oficialmente, correspondendo a 4 Hs., 6 Hs. ou 8 Hs. diárias durante cinco dias da semana. Com a exceção do INAMPS(118,119,120) e da FSESP(222), entidades que contratam profissionais em todo o país uniformemente com 30 Hs. no primeiro caso e 40 Hs. no segundo, a estratificação por tempo contratado nos demais casos foi obtida através dos questionários aplicados através do estudo desenvolvido pela Divisão Nacional de Saúde Bucal em $1989(46,47,116,118)$.

Para as "Outras Instituições" o padrão utilizado - com base nas informações do estudo da DNSB e nas provenientes do SESI e SESC - foi de que em cada estado $80 \%$ dos profissionais estavam contratados para trabalhar vinte horas semanais, enquanto que os restantes 208 adotavam o regime de trinta horas semanais $(214,217)$.

No caso dos Sindicatos considerou-se que o total de Cirurgiōes-Dentistas é igual ao número de contratos com o INAMPS multiplicado por 2, a partir de dados reais de cinco estados(119). Sabe-se que em diversos sindicatos há um número maior de odontólogos trabalhando, enquanto que em outros apenas um está disponível, mas a informação precisa a este respeito para todas as Unidades Federadas não está disponível.

o número de Credenciados corresponde à informação do INAMPS referente às Pessoas Físicas. Adotou-se uma estimativa de aproximadamente 2,167 profissionais por Pessoa Jurídica credenciada, seguindo o padrão médio a este respeito observado em Minas Gerais, Paraná e Pará.

Para os Sindicatos e para os Credenciados o regime de 20 Hs. semanais de trabalho é que foi aceito como o padrão para todos os estados. 
$5 \mathrm{~A}$

$A N E X O I I$ 


\section{A) TABELA 17}

A Tabela reproduz fielmente os dados publicados na Pesquisa de orçamentos Familiares -P.O.F.- da Fundação IBGE(107), no que se refere a todos os gastos pessoais com saúde em geral e com tratamento dentário em específico.

A transposição de cruzeiros para dólares, na base de US\$ $1=$ Cr\$53,407, foi feita considerando o valor de câmbio oficial em 15/10/1987, que é a data de referência básica adotada na Pesquisa $(14,16,107)$.

Para encontrar valores per capita dividiu-se os dispêndios por família pelo número médio de pessoas por família, de acordo com os dados fornecidos pela própria P.O.F.

B) TABELAS 18 E 19

Para estimar os gastos com saúde geral e com tratamento dentário para toda a população, os seguintes critérios foram adotados:

- 1989 foi tomado como ano de referência visando compatibilizar estes dados com os demais, relativos a recursos humanos, serviços, situação econômica, etc.;

- para a estratificação da população por zona de estimativas utilizou-se dados do estudo do IPEA (127) que fornece cidade por cidade fornecida no Suplemento do Anuário Estatístico de $1989(4)$. A população das "outras cidades" foi obtida por diferença entre a população da egião Metropolitana -R.M.- ou capital (nos estados onde não há R.M.) e a da zona rural;

- os gastos per capita em dólares obtidos na Tabela 17 foram considerados como válidos e reais para 1989 ;

- para chegar ao gasto médio de cada região utilizou-se a média ponderada dos gastos das R.M. ou capitais disponíveis na P.O.F. Considerou-se, portanto, que as pessoas residentes nas demais capitais teriam padrões de despesas com saúde similares às das R.M. ou capitais da mesma região. No exemplo a seguir está o gasto médio do Nordeste:

(US\$ $7,10 \times 1.976 .645+$ US $\$ 4,43 \times 2.608 .397+$ US $\$ 8,31 \times 2.189 .406$ )

(População de Fortaleza + Recife + Salvador) $=6,73$

- o rendimento médio mensal das pessoas com 10 anos e mais, estratificado para as R.M., demais cidades e zona rural, foi obtido através da PNAD/88 (Tab.3.3 da PNAD) (109), por ser a informação disponível mais próxima no tempo e mais compatível com a Pesquisa. Considerou-se que a variação dos gastos em saúde nessas zonas era similar à verificada quanto aos rendimentos; 
- assim, foram aplicados redutores (fatores de redução) sobre os gastos médios das R.M., para obter os gastos médios nas demais cidades e na zona rural. Esses redutores, idênticos aos fornecidos pela PNAD/88 para os rendimentos, são os seguintes respectivamente para as demais cidades e zona rural: Norte 0,70 e 0,310 - Nordeste 0,539 e 0,284 - Sudeste 0,810 e 0,310 - Sul 0,741 e 0,336 - CentroOeste 0,70 e 0,310 . Os redutores das regiões Norte e Centro-Oeste para a zona rural foram estimados em função das médias das demais regiões. 
8 A

A $N E X O I I I$

CRITÉRIOS PARA ESTIMȦTIVAS DOS GASTOS INSTITUCIONAIS 


\section{TABELA 21}

\section{A) SERVIÇOS PRÓPRIOS DO INAMPS}

A base de cálculo foi o salário médio de 1989, estimado em US\$ 960.00 ao mês(119),. Para chegar ao total de dispêndios com serviços próprios, a expressão a seguir foi utilizada:

- US\$ $960 \times 2546$ CDs $\times 1,45$ (encargos sociais) $\times 13$ meses $\mathrm{x}$ 1,1765 (1/0,85, ou seja, adicional de 158 para manutenção $e$ material de consumo) $\times 1,30$ (pessoal auxiliar e investimentos) = US\$ 70,466 milhões.

\section{B) PROFISSIONAIS CREDENCIADOS}

- montante despendido com Pessoas Físicas e Jurídicas credenciadas mais o que é pago aos Sindicatos consta do Balanço Anual do INAMPS ou dos quadros de despesa elaborados pela área financeira da entidade(113,114,119). Para 1989 os valores em cruzeiros foram transformados em dólares considerando o valor médio de conversão, no ano, publicado pelo Banco Central do Brasil - US\$ 1 = $\mathrm{NCz} \$ 2,828^{(16)}$.

Assim, os gastos de NCz\$173.778.713,00, equivaleram a US\$ 61.449.000,00. A divisão entre Credenciados e Sindicatos foi feita segundo o número de consultas pagas no ano, ou seja, 9,6 milhões produzidas nos sindicatos e 6,1 milhões nas clínicas dos credenciados(119). Daí resulta que US\$23,96 milhões couberam aos primeiros e US $\$ 37,48$ milhões aos Sindicatos, com uma média respectivamente de US\$3,9287 e de US\$3,9046 por consulta. Vale notar que nesta rubrica estão também incluidos os pagamentos feitos pela previdência social às Entidades Filantrópicas.

\section{C) ÓRGÃOS PÚBLICOS}

- INAMPS tinha 1347 convênios firmados com instituiçōes públicas em 89, com uma produção de 12,6 milhões de consultas. Considerou-se um preço médio por consulta similar ao que foi pago aos Sindicatos, de US\$3,9046, obtendo o montante total de US\$ 49,2 milhões nesta modalidade $(119,120)$.

- repasse desses valores para os Estados e Municípios teve sua divisão calculada em função das respectivas capacidades instaladas em termos de horas contratadas de trabalho(118). Em consequência coube aos organismos estaduais 808 dos recursos no Norte, 798 no Nordeste, 388 no Sudeste, 348 no sul e 838 no Centro-Oeste, conforme dados provenientes da Tabela 15 (p.ex., no Centro-Oeste os postos de trabalho estaduais somam 25810 horas semanais, contra 5190 dos municipais, o que dá uma relação de 83:17); 


\section{D) SECRETARIAS DE SAÚdE E EDUCAÇÃO DOS ESTADOS}

Um salário médio, ou seja, de profissionais em meio de carreira, foi obtido para a maioria dos estados no estudo da DNSB, com especificação para cada grupo em termos de horas contratadas(47). Em alguns casos foram fornecidos os gastos globais com pessoal e em outros apenas valores para o grupo com 4 horas/dia de trabalho. Para efeitos do presente estudo tomou-se como referência o salário médio dos profissionais com 20 horas semanais, padronizando-se um acréscimo de 408 para a faixa de 30 horas e de 808 para a de 40 horas. Daí foi possível calcular valores salariais aproximados por região, como se vê a seguir:

- Norte $=$ US $\$ 412$ (20 Hs), US\$ 577 (30 Hs) e US\$ 742 (40 Hs)

- Nordeste $=$ respectivamente US\$382, 535 e 688

- Sudeste e Centro-Oeste $=$ US\$ 600,840 e 1080

- Sul = US\$720, 1008 e 1296 .

Esses valores foram aplicados aos dados da Tabela 15 com a seguinte fórmula básica: Número de Profissionais x Salário médio em cada faixa $(20,30$ e 40 Hs) x 13 meses $x 1,45$ de encargos sociais $x$ 1,1765 para material de consumo $\mathrm{x} 1,40$ para pessoal auxiliar e outros gastos. Para simplificar o cálculo, temos: Profissionais $x$ Salário x 31,05.

Incluem-se neste tópico os odontólogos que trabalham nas Secretarias de Saúde, de Educação e outros organismos da administração direta estadual.

Dos gastos totais a nível estadual foram subtraidos os repasses do INAMPS.

E) MUNICÍPIOS

Para as Prefeituras Municipais valem os mesmos valores e critérios adotados para os organismos estaduais. Dos gastos a este nível retirou-se o que foi pago pelo INAMPS para evitar dupla contagem.

\section{F) OUTRAS INSTITUIÇŌES}

Os salários médios adotados são, para efeitos de cálculo das despesas, os mesmos pagos pelos Estados e Municípios, multiplicado pelo fator 31,05 como está explicado no ítem "d" acima. Há diferenças entre níveis salariais das diversas entidades quando se faz uma comparação dos dados disponíveis para alguns estados, mas estas diferenças variam óra favorecendo uma instituição e óra outra, fazendo com que as médias gerais tenham valores aproximados.

G) MINISTÉRIO DA SAÚDE 
Os gastos da Divisão Nacional de Saúde Bucal e da Fundação SESP (Seção de Saúde Oral a nível central mais serviços nos Estados) correspondem às execuçōes orçamentárias de $1989{ }^{(44)}$.

H) FLUORETAÇÃO DA ÁGUA

Segundo a "Relação das localidades com fluoretação da água" de 1989(52), cerca de 64 milhões de pessoas eram beneficiadas por este método no país. Com base em estudos brasileiros recentes(51), calculou-se em US\$ 0,15 por pessoa ao ano 0 gasto com o sistema, incluindo a manutenção, compra do sal e eventuais despesas de reparação. A divisão por regiões seguiu as mesmas proporções da população coberta nas 1222 localidades onde o método estava sendo aplicado.

I) TOTAL DE GASTOS PÚBLICOS

A cifra de US $\$ 716.276 .000,00$ corresponde ao somatório das despesas com saúde bucal efetuadas pelo INAMPS, organismos estaduais e municipais, outras instituiçōes oficiais e paraoficiais, Ministério da Saúde e Companhias de Abastecimento D'água com fluoretação. Considera-se, portanto, que esta é uma aproximação dos gastos totais do setor público, tomando em consideração as despesas com pessoal, outros custeios e investimentos, estes no que se refere principalmente a materiais e equipamentos.

\section{J) GASTOS PESSOAIS}

Os critérios são os mesmos utilizados para a estruturação das Tabelas 17 e 19. De acordo com a Pesquisa de Orçamentos Familiares feita pela Fundação IBGE(107), a estimativa constante da Tabela 21 representa a totalidade dos desembolsos das familias com "atendimento dentário", ou seja, com o pagamento de serviços odontológicos de qualquer tipo.

\section{L) GASTOS TOTAIS}

Constituem o somatório dos gastos públicos e dos desembolsos pessoais. Até onde é possível discriminar essas despesas, cada uma é computada uma só vez, evitando-se duplas contagens. o valor de 2,4 bilhões de dólares correspondia, em 1989, a NCz\$ 6,77 bilhões. 
TABELAI (ANEXOM)

ESTIMATIVA DA POPULACIOO URBANA POA

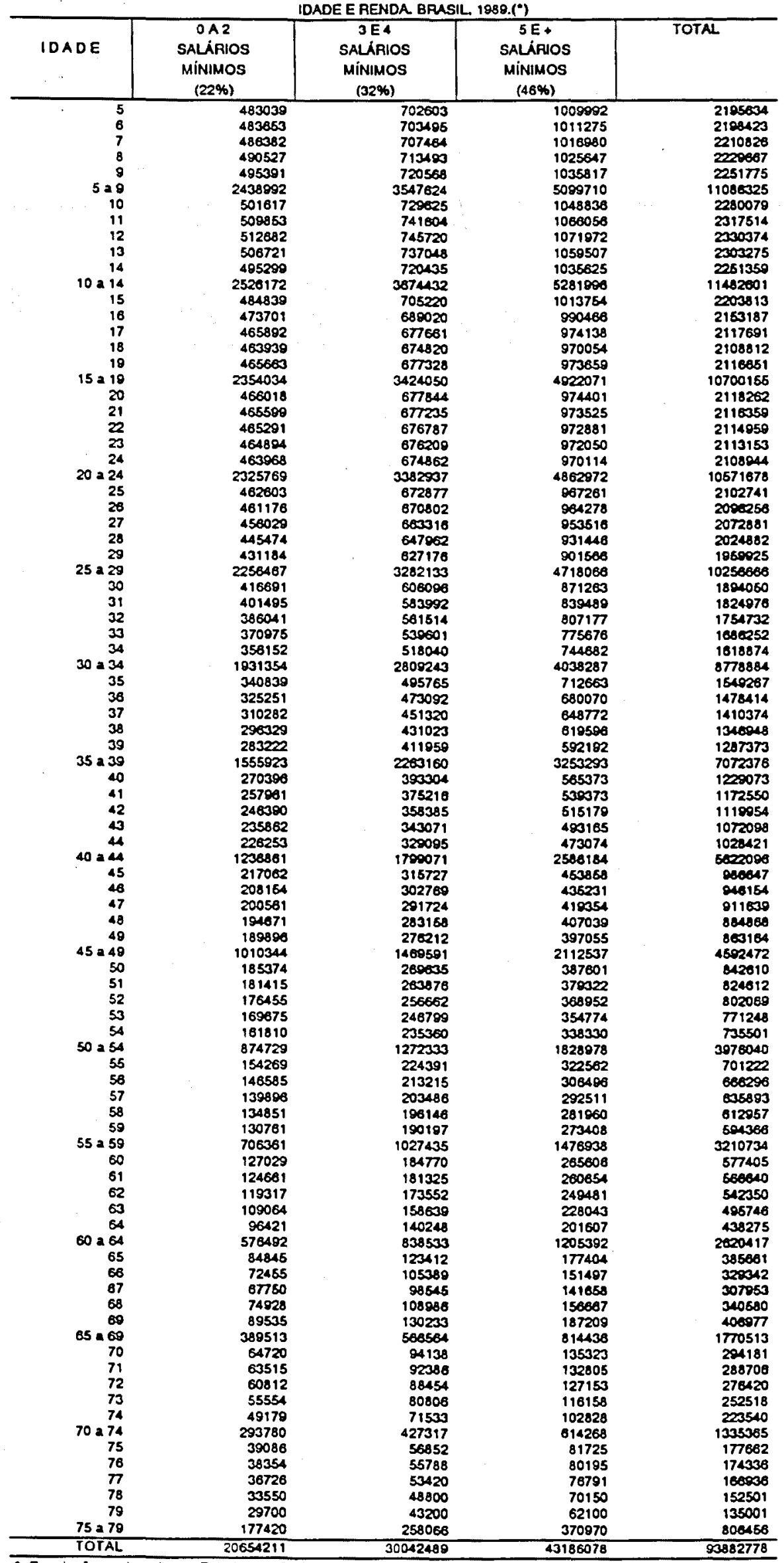


A $N E X O V$

INDICADORES DE SAÚDE BUCAL:

PERCENTUAIS POR IDADES EXATAS, INTERVALOS DE CONFIANÇA, ANÁLISE DE VARIÂNCIA E PARÂMETROS ESTATÍSTICOS ESTIMADOS 
TABELAII (ANEXO V)

PERCENTUAL DE DENTES ATACADOS PELA CÁRIE SEQUNDO IDADE E RENDA, COM O INTERIVALO DE CONFIANCA. INDICE CPO-D. BRUSIL, ZONA URBANA (")

\begin{tabular}{|c|c|c|c|c|c|c|c|c|c|}
\hline \multirow[t]{2}{*}{ TDADE } & \multicolumn{3}{|c|}{ RENDA I } & \multicolumn{3}{|c|}{ RENDA 2} & \multicolumn{3}{|c|}{ RENDA 3} \\
\hline & * CPO & SUP & INF & $\%$ CPO & SUP & INF & $\%$ CPO & SUP & INF \\
\hline $\begin{array}{l}5 \\
6 \\
7 \\
8 \\
0\end{array}$ & $\begin{array}{l}0,207 \\
0,217 \\
0,227 \\
0,237 \\
0,248\end{array}$ & $\begin{array}{l}0,190 \\
0,200 \\
0,210 \\
0,220 \\
0,231\end{array}$ & $\begin{array}{l}0,224 \\
0,234 \\
0,246 \\
0,255 \\
0,266\end{array}$ & $\begin{array}{l}0,108 \\
0,207 \\
0,217 \\
0,227 \\
0,238\end{array}$ & $\begin{array}{l}0,170 \\
0,190 \\
0,200 \\
0,211 \\
0.221\end{array}$ & $\begin{array}{l}0,213 \\
0,224 \\
0,234 \\
0,245 \\
0.255\end{array}$ & $\begin{array}{l}0,171 \\
0,181 \\
0,190 \\
0,201 \\
0,211\end{array}$ & $\begin{array}{l}0,156 \\
0,165 \\
0,174 \\
0,184 \\
0,185\end{array}$ & $\begin{array}{l}0,188 \\
0,197 \\
0,207 \\
0,218 \\
0,228\end{array}$ \\
\hline $\begin{array}{l}10 \\
11 \\
12 \\
13 \\
14\end{array}$ & $\begin{array}{l}0,259 \\
0,270 \\
0,281 \\
0,310 \\
0,322\end{array}$ & $\begin{array}{l}0,242 \\
0,253 \\
0,264 \\
0,223 \\
0,304\end{array}$ & $\begin{array}{l}0,276 \\
0,287 \\
0,298 \\
0,328 \\
0,340\end{array}$ & $\begin{array}{l}0,249 \\
0,259 \\
0,270 \\
0,298 \\
0,311\end{array}$ & $\begin{array}{l}0,232 \\
0,243 \\
0,254 \\
0,281 \\
0,293\end{array}$ & $\begin{array}{l}0,266 \\
0,276 \\
0,287 \\
0,316 \\
0,328\end{array}$ & $\begin{array}{l}0,221 \\
0,232 \\
0,242 \\
0,268 \\
0,280\end{array}$ & $\begin{array}{l}0,205 \\
0,216 \\
0,226 \\
0,251 \\
0,263\end{array}$ & $\begin{array}{l}0,238 \\
0,248 \\
0,259 \\
0,285 \\
0,297\end{array}$ \\
\hline $\begin{array}{l}15 \\
16 \\
17 \\
18 \\
19\end{array}$ & $\begin{array}{l}0,371 \\
0,385 \\
0,308 \\
0,412 \\
0,428\end{array}$ & $\begin{array}{l}0,352 \\
0,365 \\
0,379 \\
0,393 \\
0,407\end{array}$ & $\begin{array}{l}0,391 \\
0,404 \\
0,418 \\
0,432 \\
0,446\end{array}$ & $\begin{array}{l}0,358 \\
0,372 \\
0,385 \\
0,300 \\
0,413\end{array}$ & $\begin{array}{l}0,339 \\
0,352 \\
0,368 \\
0,380 \\
0,394\end{array}$ & $\begin{array}{l}0,378 \\
0,391 \\
0,405 \\
0,418 \\
0,432\end{array}$ & $\begin{array}{l}0,324 \\
0,337 \\
0,351 \\
0,364 \\
0,377\end{array}$ & $\begin{array}{l}0,305 \\
0,318 \\
0,332 \\
0,345 \\
0,360\end{array}$ & $\begin{array}{l}0,343 \\
0,356 \\
0,370 \\
0,383 \\
0,398\end{array}$ \\
\hline $\begin{array}{l}20 \\
21 \\
22 \\
23 \\
24\end{array}$ & $\begin{array}{l}0,440 \\
0,454 \\
0,468 \\
0,482 \\
0,496\end{array}$ & $\begin{array}{l}0,421 \\
0,435 \\
0,449 \\
0,463 \\
0,478\end{array}$ & $\begin{array}{l}0,458 \\
0,473 \\
0,487 \\
0,500 \\
0,514\end{array}$ & $\begin{array}{l}0,428 \\
0,440 \\
0,464 \\
0,468 \\
0,482\end{array}$ & $\begin{array}{l}0,408 \\
0,422 \\
0,436 \\
0,450 \\
0,464\end{array}$ & $\begin{array}{l}0,445 \\
0,450 \\
0,473 \\
0,487 \\
0,601\end{array}$ & $\begin{array}{l}0,391 \\
0,405 \\
0,410 \\
0,433 \\
0,466\end{array}$ & $\begin{array}{l}0,373 \\
0,386 \\
0,400 \\
0,414 \\
0,428\end{array}$ & $\begin{array}{l}0,410 \\
0,423 \\
0,437 \\
0,451 \\
0,465\end{array}$ \\
\hline $\begin{array}{l}25 \\
26 \\
27 \\
28 \\
29\end{array}$ & $\begin{array}{l}0,510 \\
0,524 \\
0,538 \\
0,552 \\
0,566\end{array}$ & $\begin{array}{l}0,492 \\
0,508 \\
0,520 \\
0,534 \\
0,548\end{array}$ & $\begin{array}{l}0,528 \\
0,542 \\
0,556 \\
0,569 \\
0,583\end{array}$ & $\begin{array}{l}0,496 \\
0,510 \\
0,524 \\
0,538 \\
0,552\end{array}$ & $\begin{array}{l}0,478 \\
0,492 \\
0,507 \\
0,521 \\
0,535\end{array}$ & $\begin{array}{l}0,514 \\
0,528 \\
0,542 \\
0,656 \\
0,570\end{array}$ & $\begin{array}{l}0,460 \\
0,474 \\
0,488 \\
0,502 \\
0,516\end{array}$ & $\begin{array}{l}0,442 \\
0,456 \\
0,471 \\
0,485 \\
0,499\end{array}$ & $\begin{array}{l}0,478 \\
0,492 \\
0,507 \\
0,520 \\
0.534\end{array}$ \\
\hline $\begin{array}{l}30 \\
31 \\
32 \\
33 \\
34\end{array}$ & $\begin{array}{l}0,580 \\
0,593 \\
0,607 \\
0,621 \\
0,634\end{array}$ & $\begin{array}{l}0,562 \\
0,576 \\
0,590 \\
0,604 \\
0,618\end{array}$ & $\begin{array}{l}0,597 \\
0,611 \\
0,624 \\
0,638 \\
0,651\end{array}$ & $\begin{array}{l}0,568 \\
0,580 \\
0,584 \\
0,808 \\
0,621\end{array}$ & $\begin{array}{l}0,549 \\
0,563 \\
0,577 \\
0,591 \\
0,604\end{array}$ & $\begin{array}{l}0,684 \\
0.587 \\
0,611 \\
0,625 \\
0,638\end{array}$ & $\begin{array}{l}0,530 \\
0,544 \\
0,558 \\
0,572 \\
0,586\end{array}$ & $\begin{array}{l}0,513 \\
0,527 \\
0,541 \\
0,555 \\
0,569\end{array}$ & $\begin{array}{l}0,548 \\
0.562 \\
0,576 \\
0,588 \\
0,603\end{array}$ \\
\hline $\begin{array}{l}35 \\
36 \\
37 \\
38 \\
39\end{array}$ & $\begin{array}{l}0,648 \\
0,661 \\
0,674 \\
0,687 \\
0,700\end{array}$ & $\begin{array}{l}0,631 \\
0,645 \\
0,658 \\
0,671 \\
0,684\end{array}$ & $\begin{array}{l}0,664 \\
0,678 \\
0,681 \\
0,704 \\
0,716\end{array}$ & $\begin{array}{l}0,635 \\
0,648 \\
0,700 \\
0,675 \\
0,688\end{array}$ & $\begin{array}{l}0,618 \\
0,632 \\
0,645 \\
0,658 \\
0,671\end{array}$ & $\begin{array}{l}0,652 \\
0,665 \\
0,678 \\
0,691 \\
0,704\end{array}$ & $\begin{array}{l}0,600 \\
0,633 \\
0,662 \\
0,641 \\
0,654\end{array}$ & $\begin{array}{l}0,583 \\
0,597 \\
0,610 \\
0,624 \\
0,637\end{array}$ & $\begin{array}{l}0,617 \\
0,630 \\
0,644 \\
0,657 \\
0,671\end{array}$ \\
\hline $\begin{array}{l}40 \\
41 \\
42 \\
43 \\
44\end{array}$ & $\begin{array}{l}0,713 \\
0,726 \\
0,738 \\
0,750 \\
0,762\end{array}$ & $\begin{array}{l}0,687 \\
0,710 \\
0,722 \\
0,735 \\
0,747\end{array}$ & $\begin{array}{l}0,729 \\
0,742 \\
0,754 \\
0,766 \\
0,778\end{array}$ & $\begin{array}{l}0,701 \\
0,714 \\
0,726 \\
0,739 \\
0,751\end{array}$ & $\begin{array}{l}0,684 \\
0,687 \\
0,710 \\
0,722 \\
0,735\end{array}$ & $\begin{array}{l}0,717 \\
0,730 \\
0,742 \\
0,754 \\
0,786\end{array}$ & $\begin{array}{l}0,667 \\
0,680 \\
0,683 \\
0,706 \\
0,710\end{array}$ & $\begin{array}{l}0,651 \\
0,664 \\
0,677 \\
0,690 \\
0,702\end{array}$ & $\begin{array}{l}0,684 \\
0,697 \\
0,710 \\
0,723 \\
0,735\end{array}$ \\
\hline $\begin{array}{l}45 \\
46 \\
47 \\
48 \\
48\end{array}$ & $\begin{array}{l}0,774 \\
0,788 \\
0,797 \\
0,808 \\
0,818\end{array}$ & $\begin{array}{l}0,759 \\
0,770 \\
0,782 \\
0,783 \\
0,804\end{array}$ & $\begin{array}{l}0,700 \\
0,801 \\
0,812 \\
0,823 \\
0,834\end{array}$ & $\begin{array}{l}0,763 \\
0,775 \\
0,786 \\
0,788 \\
0,808\end{array}$ & $\begin{array}{l}0,747 \\
0,769 \\
0,771 \\
0,782 \\
0,793\end{array}$ & $\begin{array}{l}0,778 \\
0,780 \\
0,801 \\
0,813 \\
0,824\end{array}$ & $\begin{array}{l}0,732 \\
0,744 \\
0,756 \\
0,768 \\
0,780\end{array}$ & $\begin{array}{l}0,715 \\
0,727 \\
0,740 \\
0,752 \\
0,763\end{array}$ & $\begin{array}{l}0,748 \\
0,760 \\
0,772 \\
0,784 \\
0,795\end{array}$ \\
\hline $\begin{array}{l}50 \\
51 \\
52 \\
53 \\
54\end{array}$ & $\begin{array}{l}0,830 \\
0.840 \\
0,851 \\
0,860 \\
0,870\end{array}$ & $\begin{array}{l}0,815 \\
0,826 \\
0,836 \\
0,846 \\
0,856\end{array}$ & $\begin{array}{l}0,844 \\
0,855 \\
0,865 \\
0,874 \\
0,884\end{array}$ & $\begin{array}{l}0,820 \\
0,830 \\
0,841 \\
0,851 \\
0,861\end{array}$ & $\begin{array}{l}0,804 \\
0,815 \\
0,826 \\
0,836 \\
0,846\end{array}$ & $\begin{array}{l}0,834 \\
0,845 \\
0,855 \\
0,865 \\
0.875\end{array}$ & $\begin{array}{l}0,791 \\
0,802 \\
0,814 \\
0,824 \\
0,835\end{array}$ & $\begin{array}{l}0,775 \\
0,786 \\
0,708 \\
0,809 \\
0,819\end{array}$ & $\begin{array}{l}0,807 \\
0,818 \\
0,828 \\
0,840 \\
0,850\end{array}$ \\
\hline $\begin{array}{l}55 \\
56 \\
57 \\
58 \\
59\end{array}$ & $\begin{array}{l}0,878 \\
0,888 \\
0,807 \\
0,905 \\
0,913\end{array}$ & $\begin{array}{l}0,865 \\
0,874 \\
0,883 \\
0,892 \\
0,800\end{array}$ & $\begin{array}{l}0,893 \\
0,901 \\
0,910 \\
0,818 \\
0,925\end{array}$ & $\begin{array}{l}0,870 \\
0,880 \\
0,888 \\
0,887 \\
0,806\end{array}$ & $\begin{array}{l}0,856 \\
0,865 \\
0,875 \\
0,883 \\
0,882\end{array}$ & $\begin{array}{l}0,884 \\
0,893 \\
0,902 \\
0,810 \\
0,818\end{array}$ & $\begin{array}{l}0,845 \\
0,855 \\
0,865 \\
0,874 \\
0,883\end{array}$ & $\begin{array}{l}0,830 \\
0,840 \\
0,850 \\
0,859 \\
0,869\end{array}$ & $\begin{array}{l}0,860 \\
0,870 \\
0,878 \\
0,888 \\
0,887\end{array}$ \\
\hline $\begin{array}{l}60 \\
61 \\
62 \\
63 \\
64\end{array}$ & $\begin{array}{l}0,821 \\
0,928 \\
0,935 \\
0,842 \\
0,848\end{array}$ & $\begin{array}{l}0,808 \\
0,916 \\
0,824 \\
0,931 \\
0,837\end{array}$ & $\begin{array}{l}0,833 \\
0,940 \\
0,846 \\
0,853 \\
0,859\end{array}$ & $\begin{array}{l}0,814 \\
0,821 \\
0,829 \\
0,836 \\
0,842\end{array}$ & $\begin{array}{l}0,800 \\
0,908 \\
0,816 \\
0,824 \\
0,931\end{array}$ & $\begin{array}{l}0,926 \\
0,933 \\
0,840 \\
0,947 \\
0,853\end{array}$ & $\begin{array}{l}0,892 \\
0,901 \\
0,808 \\
0,017 \\
0,825\end{array}$ & $\begin{array}{l}0,878 \\
0,887 \\
0,885 \\
0,803 \\
0,811\end{array}$ & $\begin{array}{l}0,806 \\
0,814 \\
0,922 \\
0,930 \\
0,937\end{array}$ \\
\hline $\begin{array}{l}65 \\
66 \\
67 \\
68 \\
69\end{array}$ & $\begin{array}{l}0,855 \\
0,860 \\
0,666 \\
0,070 \\
0,075\end{array}$ & $\begin{array}{l}0,944 \\
0,950 \\
0,056 \\
0,961 \\
0,966\end{array}$ & $\begin{array}{l}0,864 \\
0,860 \\
0,974 \\
0,079 \\
0,082\end{array}$ & $\begin{array}{l}0,849 \\
0,065 \\
0,860 \\
0,866 \\
0,871\end{array}$ & $\begin{array}{l}0,937 \\
0,944 \\
0,850 \\
0,956 \\
0,961\end{array}$ & $\begin{array}{l}0,859 \\
0,965 \\
0,970 \\
0,974 \\
0,970\end{array}$ & $\begin{array}{l}0,932 \\
0,930 \\
0,845 \\
0,951 \\
0,957\end{array}$ & $\begin{array}{l}0,819 \\
0,826 \\
0,833 \\
0,840 \\
0,846\end{array}$ & $\begin{array}{l}0,844 \\
0,950 \\
0,856 \\
0,862 \\
0,967\end{array}$ \\
\hline $\begin{array}{l}70 \\
71 \\
72 \\
73 \\
74\end{array}$ & $\begin{array}{l}0,978 \\
0,883 \\
0,986 \\
0,988 \\
0,892\end{array}$ & $\begin{array}{l}0,971 \\
0,975 \\
0,978 \\
0,983 \\
0,986\end{array}$ & $\begin{array}{l}0,886 \\
0,889 \\
0,992 \\
0,804 \\
0,806\end{array}$ & $\begin{array}{l}0,875 \\
0,878 \\
0,883 \\
0,887 \\
0,880\end{array}$ & $\begin{array}{l}0,866 \\
0,971 \\
0,875 \\
0,979 \\
0,883\end{array}$ & $\begin{array}{l}0,883 \\
0,886 \\
0,988 \\
0,892 \\
0,894\end{array}$ & $\begin{array}{l}0,863 \\
0,988 \\
0,973 \\
0,977 \\
0,981\end{array}$ & $\begin{array}{l}0,052 \\
0,858 \\
0,063 \\
0,968 \\
0,073\end{array}$ & $\begin{array}{l}0,872 \\
0,877 \\
0,981 \\
0,985 \\
0,888\end{array}$ \\
\hline $\begin{array}{l}75 \\
76 \\
77 \\
78 \\
78\end{array}$ & $\begin{array}{l}0,894 \\
0,996 \\
0,998 \\
0,899 \\
1,000\end{array}$ & $\begin{array}{l}0,989 \\
0,992 \\
0,984 \\
0,986 \\
0,998\end{array}$ & $\begin{array}{l}0,999 \\
0,999 \\
1,000 \\
1,000 \\
1,000\end{array}$ & $\begin{array}{l}0,992 \\
0,894 \\
0,896 \\
0,898 \\
0,899\end{array}$ & $\begin{array}{l}0,986 \\
0,989 \\
0,992 \\
0,994 \\
0,896\end{array}$ & $\begin{array}{l}0,996 \\
0,898 \\
1,000 \\
1,000 \\
1,000\end{array}$ & $\begin{array}{l}0,885 \\
0,988 \\
0,891 \\
0,993 \\
0,995\end{array}$ & $\begin{array}{l}0,877 \\
0,881 \\
0,884 \\
0,887 \\
0,890\end{array}$ & $\begin{array}{l}0,991 \\
0,993 \\
1,000 \\
1,000 \\
1,000\end{array}$ \\
\hline
\end{tabular}


TABELA III (ANEXO V)

ANÁLISE DE VARIĀNCIA E PARÁMETROS ESTIMADOS

PARA OS VALORES DA TABELA II: INDICE CPO-D.( $\left(^{\circ}\right)$

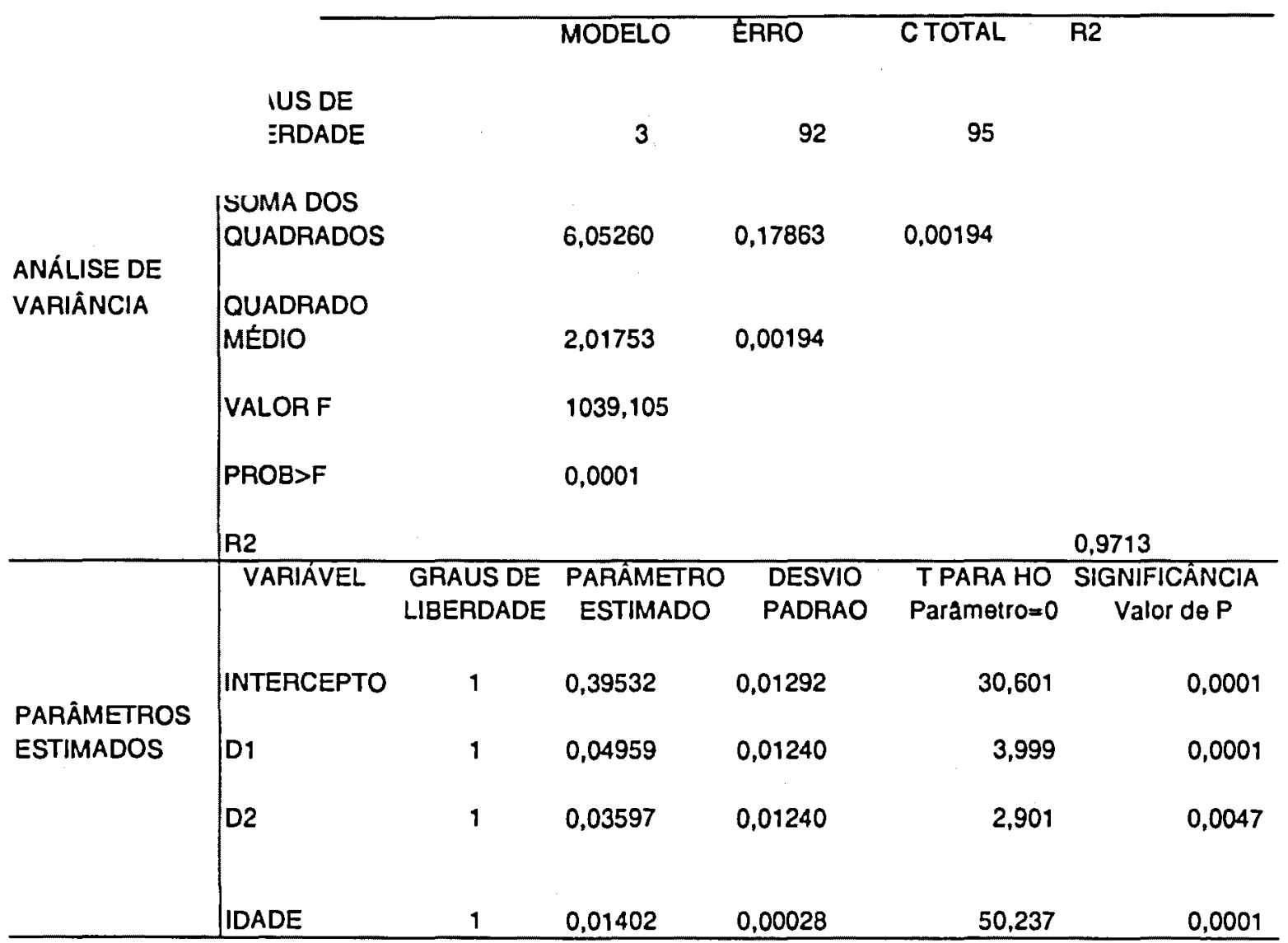

$\because$ Referencia para a Tabela 23. 
TABELA IV (ANEXOV

PEACENTUAL DE TRATAMENTOS FEITOS - FATORESS O+E DO INDICE CPOD - COM OINTERVALO DE CONFLNGA, SEOUNDO A IOADE EA

\begin{tabular}{|c|c|c|c|c|c|c|c|c|c|}
\hline \multirow{2}{*}{ IDADE } & \multicolumn{3}{|c|}{ RENDA 1} & \multicolumn{3}{|c|}{ RENDA 2} & \multicolumn{3}{|c|}{ RENDA 3} \\
\hline & $\% O+E$ & INT.INF. & INT.SUP. & $\% O+E$ & INT.INF. & INT.SUP. & $\% O+E$ & INT.INF. & INT.SUP. \\
\hline $\begin{array}{l}5 \\
6 \\
7 \\
8 \\
0\end{array}$ & $\begin{array}{l}0,047 \\
0,054 \\
0,061 \\
0,069 \\
0,077\end{array}$ & $\begin{array}{l}0,035 \\
0,042 \\
0,048 \\
0,055 \\
0,063\end{array}$ & $\begin{array}{l}0,060, \\
0,068 \\
0,076 \\
0,083 \\
0,092\end{array}$ & $\begin{array}{l}0,061 \\
0,060 \\
0,077 \\
0,086 \\
0,095\end{array}$ & $\begin{array}{l}0,048 \\
0,055 \\
0,063 \\
0,071 \\
0,079\end{array}$ & $\begin{array}{l}0,077 \\
0,084 \\
0,024 \\
0,102 \\
0,111\end{array}$ & $\begin{array}{l}0,065 \\
0,072 \\
0,081 \\
0,089 \\
0,089\end{array}$ & $\begin{array}{l}0,051 \\
0,058 \\
0,068 \\
0,074 \\
0,083\end{array}$ & $\begin{array}{l}0,080 \\
0,088 \\
0,097 \\
0,106 \\
0,116\end{array}$ \\
\hline $\begin{array}{l}10 \\
11 \\
12 \\
13 \\
14\end{array}$ & $\begin{array}{l}0,085 \\
0,094 \\
0,104 \\
0,120 \\
0,130\end{array}$ & $\begin{array}{l}0,071 \\
0,079 \\
0,088 \\
0,110 \\
0,113\end{array}$ & $\begin{array}{l}0,101 \\
0,110 \\
0,120 \\
0,138 \\
0,149\end{array}$ & $\begin{array}{l}0,104 \\
0,114 \\
0,124 \\
0,142 \\
0,163\end{array}$ & $\begin{array}{l}0,088 \\
0,097 \\
0,107 \\
0,124 \\
0,135\end{array}$ & $\begin{array}{l}0,121 \\
0.131 \\
0,142 \\
0,161 \\
0,173\end{array}$ & $\begin{array}{l}0,108 \\
0,118 \\
0,128 \\
0,147 \\
0,158\end{array}$ & $\begin{array}{l}0,092 \\
0,101 \\
0,111 \\
0,128 \\
0,140\end{array}$ & $\begin{array}{l}0,126 \\
0,136 \\
0,146 \\
0,166 \\
0,178\end{array}$ \\
\hline $\begin{array}{l}15 \\
16 \\
17 \\
18 \\
10\end{array}$ & $\begin{array}{l}0,167 \\
0,170 \\
0,183 \\
0,186 \\
0,210\end{array}$ & $\begin{array}{l}0,138 \\
0,160 \\
0,162 \\
0,175 \\
0,189\end{array}$ & $\begin{array}{l}0,178 \\
0,191 \\
0,204 \\
0,218 \\
0,232\end{array}$ & $\begin{array}{l}0.184 \\
0,197 \\
0,211 \\
0,225 \\
0,239\end{array}$ & $\begin{array}{l}0,163 \\
0,176 \\
0,189 \\
0,203 \\
0,217\end{array}$ & $\begin{array}{l}0,205 \\
0,219 \\
0,233 \\
0,247 \\
0,262\end{array}$ & $\begin{array}{l}0,189 \\
0,203 \\
0,217 \\
0,231 \\
0,245\end{array}$ & $\begin{array}{l}0,168 \\
0,181 \\
0,195 \\
0,200 \\
0,223\end{array}$ & $\begin{array}{l}0,211 \\
0,224 \\
0,239 \\
0,254 \\
0,288\end{array}$ \\
\hline $\begin{array}{l}20 \\
21 \\
22 \\
23 \\
24\end{array}$ & $\begin{array}{l}0,224 \\
0,238 \\
0,253 \\
0,268 \\
0,283\end{array}$ & $\begin{array}{l}0,203 \\
0,217 \\
0,231 \\
0,246 \\
0,261\end{array}$ & $\begin{array}{l}0,246 \\
0,261 \\
0,275 \\
0,291 \\
0,306\end{array}$ & $\begin{array}{l}0,254 \\
0,269 \\
0,284 \\
0,300 \\
0,315\end{array}$ & $\begin{array}{l}0,232 \\
0,246 \\
0,281 \\
0,277 \\
0,292\end{array}$ & $\begin{array}{l}0,277 \\
0,292 \\
0,307 \\
0,323 \\
0,339\end{array}$ & $\begin{array}{l}0,200 \\
0,275 \\
0,201 \\
0,306 \\
0,322\end{array}$ & $\begin{array}{l}0,238 \\
0,253 \\
0,268 \\
0,283 \\
0,299\end{array}$ & $\begin{array}{l}0,283 \\
0,298 \\
0,314 \\
0,330 \\
0,346\end{array}$ \\
\hline $\begin{array}{l}25 \\
26 \\
27 \\
28 \\
29\end{array}$ & $\begin{array}{l}0,200 \\
0,314 \\
0,330 \\
0,347 \\
0,363\end{array}$ & $\begin{array}{l}0,276 \\
0,292 \\
0.308 \\
0.324 \\
0.340\end{array}$ & $\begin{array}{l}0,322 \\
0,337 \\
0,353 \\
0,370 \\
0,386\end{array}$ & $\begin{array}{l}0,331 \\
0,347 \\
0,364 \\
0,380 \\
0,397\end{array}$ & $\begin{array}{l}0,308 \\
0,324 \\
0,341 \\
0,357 \\
0,374\end{array}$ & $\begin{array}{l}0,365 \\
0,371 \\
0,387 \\
0,404 \\
0,420\end{array}$ & $\begin{array}{l}0,338 \\
0,354 \\
0,371 \\
0,387 \\
0,404\end{array}$ & $\begin{array}{l}0,315 \\
0,331 \\
0,347 \\
0,364 \\
0,381\end{array}$ & $\begin{array}{l}0,362 \\
0,378 \\
0,394 \\
0,411 \\
0,428\end{array}$ \\
\hline $\begin{array}{l}30 \\
31 \\
32 \\
33 \\
34\end{array}$ & $\begin{array}{l}0,379 \\
0,306 \\
0,413 \\
0,430 \\
0,447\end{array}$ & $\begin{array}{l}0,356 \\
0,373 \\
0,389 \\
0,406 \\
0,423\end{array}$ & $\begin{array}{l}0,403 \\
0,419 \\
0,436 \\
0,453 \\
0,470\end{array}$ & $\begin{array}{l}0,414 \\
0,430 \\
0,447 \\
0,464 \\
0,481\end{array}$ & $\begin{array}{l}0,300 \\
0,407 \\
0,424 \\
0,441 \\
0,458\end{array}$ & $\begin{array}{l}0,437 \\
0,464 \\
0,471 \\
0,488 \\
0,505\end{array}$ & $\begin{array}{l}0,421 \\
0,438 \\
0,455 \\
0,472 \\
0,489\end{array}$ & $\begin{array}{l}0,397 \\
0,414 \\
0,431 \\
0,448 \\
0,465\end{array}$ & $\begin{array}{l}0,444 \\
0,461 \\
0,478 \\
0,495 \\
0,512\end{array}$ \\
\hline $\begin{array}{l}35 \\
36 \\
37 \\
38 \\
39\end{array}$ & $\begin{array}{l}0,464 \\
0,481 \\
0,498 \\
0,515 \\
0,532\end{array}$ & $\begin{array}{l}0,440 \\
0,457 \\
0,474 \\
0,491 \\
0,508\end{array}$ & $\begin{array}{l}0,487 \\
0,504 \\
0,521 \\
0,539 \\
0,566\end{array}$ & $\begin{array}{l}0,499 \\
0,516 \\
0,533 \\
0,550 \\
0,567\end{array}$ & $\begin{array}{l}0,475 \\
0,492 \\
0.509 \\
0,528 \\
0,543\end{array}$ & $\begin{array}{l}0,522 \\
0,530 \\
0.558 \\
0,573 \\
0,590\end{array}$ & $\begin{array}{l}0,506 \\
0,523 \\
0,540 \\
0,557 \\
0,574\end{array}$ & $\begin{array}{l}0,482 \\
0,499 \\
0,516 \\
0,533 \\
0,560\end{array}$ & $\begin{array}{l}0,529 \\
0,547 \\
0,564 \\
0,581 \\
0,587\end{array}$ \\
\hline $\begin{array}{l}40 \\
41 \\
42 \\
43 \\
44\end{array}$ & $\begin{array}{l}0,549 \\
0,568 \\
0,583 \\
0,599 \\
0.616\end{array}$ & $\begin{array}{l}0,525 \\
0,541 \\
0,558 \\
0,575 \\
0,592\end{array}$ & $\begin{array}{l}0,573 \\
0,590 \\
0,607 \\
0,623 \\
0,640\end{array}$ & $\begin{array}{l}0,583 \\
0,600 \\
0,617 \\
0,633 \\
0,650\end{array}$ & $\begin{array}{l}0,560 \\
0,576 \\
0,503 \\
0,609 \\
0,626\end{array}$ & $\begin{array}{l}0,607 \\
0,624 \\
0,640 \\
0,657 \\
0,673\end{array}$ & $\begin{array}{l}0,691 \\
0,607 \\
0,624 \\
0,640 \\
0,657\end{array}$ & $\begin{array}{l}0,667 \\
0,583 \\
0,600 \\
0,617 \\
0,633\end{array}$ & $\begin{array}{l}0,614 \\
0,631 \\
0,647 \\
0,664 \\
0,680\end{array}$ \\
\hline $\begin{array}{l}45 \\
46 \\
47 \\
48 \\
49\end{array}$ & $\begin{array}{l}0,632 \\
0,649 \\
0,665 \\
0,681 \\
0,697\end{array}$ & $\begin{array}{l}0,608 \\
0,624 \\
0,641 \\
0,657 \\
0,672\end{array}$ & $\begin{array}{l}0,657 \\
0,673 \\
0,689 \\
0,705 \\
0,721\end{array}$ & $\begin{array}{l}0,666 \\
0,682 \\
0,698 \\
0,713 \\
0,729\end{array}$ & $\begin{array}{l}0,642 \\
0,658 \\
0.674 \\
0,689 \\
0,705\end{array}$ & $\begin{array}{l}0,688 \\
0,705 \\
0,721 \\
0,736 \\
0,762\end{array}$ & $\begin{array}{l}0,673 \\
0,689 \\
0,704 \\
0,720 \\
0,735\end{array}$ & $\begin{array}{l}0,649 \\
0,685 \\
0,681 \\
0,696 \\
0,711\end{array}$ & $\begin{array}{l}0,696 \\
0.712 \\
0,727 \\
0,743 \\
0,758\end{array}$ \\
\hline $\begin{array}{l}50 \\
51 \\
52 \\
63 \\
54\end{array}$ & $\begin{array}{l}0,712 \\
0,728 \\
0,743 \\
0,758 \\
0,772\end{array}$ & $\begin{array}{l}0,688 \\
0,703 \\
0,718 \\
0,733 \\
0,748\end{array}$ & $\begin{array}{l}0.738 \\
0,751 \\
0,786 \\
0,781 \\
0,795\end{array}$ & $\begin{array}{l}0,744 \\
0,758 \\
0,773 \\
0,787 \\
0,801\end{array}$ & $\begin{array}{l}0,720 \\
0,735 \\
0,749 \\
0,764 \\
0,778\end{array}$ & $\begin{array}{l}0,766 \\
0,781 \\
0,795 \\
0,809 \\
0,823\end{array}$ & $\begin{array}{l}0,760 \\
0,765 \\
0,779 \\
0,703 \\
0,806\end{array}$ & $\begin{array}{l}0,728 \\
0,741 \\
0,756 \\
0,770 \\
0,784\end{array}$ & $\begin{array}{l}0,773 \\
0,787 \\
0,801 \\
0,815 \\
0,828\end{array}$ \\
\hline $\begin{array}{l}65 \\
66 \\
57 \\
58 \\
59\end{array}$ & $\begin{array}{l}0,786 \\
0,800 \\
0,813 \\
0,827 \\
0,830\end{array}$ & $\begin{array}{l}0,762 \\
0,776 \\
0,700 \\
0,803 \\
0,816\end{array}$ & $\begin{array}{l}0,809 \\
0,823 \\
0,836 \\
0,849 \\
0,861\end{array}$ & $\begin{array}{l}0,814 \\
0,827 \\
0,840 \\
0,852 \\
0,864\end{array}$ & $\begin{array}{l}0,791 \\
0,805 \\
0,818 \\
0,830 \\
0,843\end{array}$ & $\begin{array}{l}0,836 \\
0,849 \\
0,861 \\
0,873 \\
0,884\end{array}$ & $\begin{array}{l}0,820 \\
0,833 \\
0,845 \\
0,857 \\
0,869\end{array}$ & $\begin{array}{l}0,797 \\
0,811 \\
0,823 \\
0,836 \\
0,848\end{array}$ & $\begin{array}{l}0,841 \\
0,854 \\
0,866 \\
0,878 \\
0,889\end{array}$ \\
\hline $\begin{array}{l}60 \\
61 \\
62 \\
63 \\
64\end{array}$ & $\begin{array}{l}0,852 \\
0,864 \\
0,875 \\
0,886 \\
0,897\end{array}$ & $\begin{array}{l}0,829 \\
0,841 \\
0,853 \\
0,865 \\
0,876\end{array}$ & $\begin{array}{l}0,873 \\
0,884 \\
0,895 \\
0,806 \\
0,816\end{array}$ & $\begin{array}{l}0,876 \\
0,887 \\
0,897 \\
0,807 \\
0,817\end{array}$ & $\begin{array}{l}0,855 \\
0,866 \\
0,877 \\
0,888 \\
0,898\end{array}$ & $\begin{array}{l}0,895 \\
0,806 \\
0,916 \\
0,025 \\
0,934\end{array}$ & $\begin{array}{l}0,880 \\
0,891 \\
0,802 \\
0.912 \\
0,821\end{array}$ & $\begin{array}{l}0,860 \\
0,671 \\
0,882 \\
0,892 \\
0,802\end{array}$ & $\begin{array}{l}0,800 \\
0,910 \\
0,920 \\
0,029 \\
0,838\end{array}$ \\
\hline $\begin{array}{l}65 \\
68 \\
67 \\
68 \\
68\end{array}$ & $\begin{array}{l}0,907 \\
0,917 \\
0,928 \\
0,934 \\
0,943\end{array}$ & $\begin{array}{l}0,887 \\
0,897 \\
0,807 \\
0,016 \\
0,825\end{array}$ & $\begin{array}{l}0,925 \\
0,934 \\
0,943 \\
0,951 \\
0,958\end{array}$ & $\begin{array}{l}0,824 \\
0,832 \\
0,838 \\
0,845 \\
0,851\end{array}$ & $\begin{array}{l}0,806 \\
0,914 \\
0,921 \\
0,920 \\
0,835\end{array}$ & $\begin{array}{l}0,941 \\
0,948 \\
0,953 \\
0,959 \\
0,964\end{array}$ & $\begin{array}{l}0,828 \\
0,835 \\
0,941 \\
0,846 \\
0,854\end{array}$ & $\begin{array}{l}0,809 \\
0,918 \\
0,825 \\
0,932 \\
0,239\end{array}$ & $\begin{array}{l}0,843 \\
0,051 \\
0,066 \\
0,861 \\
0,068\end{array}$ \\
\hline $\begin{array}{l}70 \\
71 \\
72 \\
73 \\
74\end{array}$ & $\begin{array}{l}0,949 \\
0,955 \\
0,981 \\
0,867 \\
0,972\end{array}$ & $\begin{array}{l}0,930 \\
0,936 \\
0,942 \\
0,948 \\
0,853\end{array}$ & $\begin{array}{l}0,868 \\
0,974 \\
0,980 \\
0,086 \\
0,887\end{array}$ & $\begin{array}{l}0,957 \\
0,962 \\
0,966 \\
0,972 \\
0,976\end{array}$ & $\begin{array}{l}0,941 \\
0,946 \\
0,950 \\
0,956 \\
0,957\end{array}$ & $\begin{array}{l}0,971 \\
0,976 \\
0,980 \\
0,987 \\
0,991\end{array}$ & $\begin{array}{l}0,960 \\
0,965 \\
0,970 \\
0,975 \\
0,979\end{array}$ & $\begin{array}{l}0,941 \\
0,946 \\
0,951 \\
0,956 \\
0,960\end{array}$ & $\begin{array}{l}0,974 \\
0,979 \\
0,884 \\
0,890 \\
0,894\end{array}$ \\
\hline $\begin{array}{l}75 \\
76 \\
77 \\
78 \\
79\end{array}$ & $\begin{array}{l}0,976 \\
0,280 \\
0,984 \\
0,987 \\
0,990\end{array}$ & $\begin{array}{l}0,956 \\
0,960 \\
0,969 \\
0,972 \\
0.975\end{array}$ & $\begin{array}{l}0,891 \\
0,890 \\
0,894 \\
1,000 \\
1,000\end{array}$ & $\begin{array}{l}0.980 \\
0,984 \\
0,987 \\
0,991 \\
0,993\end{array}$ & $\begin{array}{l}0,981 \\
0,964 \\
0,867 \\
0,972 \\
0,978\end{array}$ & $\begin{array}{l}0,985 \\
0,800 \\
1,000 \\
1,000 \\
1,000\end{array}$ & $\begin{array}{l}0,983 \\
0,986 \\
0,989 \\
0,892 \\
0,994\end{array}$ & $\begin{array}{l}0,964 \\
0,967 \\
0,970 \\
0,975 \\
0,979\end{array}$ & $\begin{array}{l}0,898 \\
1,000 \\
1,000 \\
1,000 \\
1,000\end{array}$ \\
\hline
\end{tabular}

$\because$ Referóncia para a Tabela 24. 
TABELA V (ANEXO V)

ANÁLISE DE VARIÂNCIA E PARÂMETROS ESTIMADOS

PARA OS VALORES DA TABELA IV: COMPONENTES

$O+E .\left(^{*}\right)$

\begin{tabular}{|c|c|c|c|c|c|c|}
\hline & & & MODELO & ERRO & C TOTAL & $\mathrm{R} 2$ \\
\hline $\begin{array}{l}\text { ANÁLISE DE } \\
\text { VARIÂNCIA }\end{array}$ & $\begin{array}{l}\text { GRAUS DE } \\
\text { LIBERDADE } \\
\text { SOMA DOS } \\
\text { QUADRADOS } \\
\text { QUADRADO } \\
\text { MEDIO } \\
\text { VALOR F } \\
\text { PROB }>F \\
\text { R2 }\end{array}$ & & $\begin{array}{c}3 \\
9,22465 \\
3,07488 \\
674,069 \\
0,0001\end{array}$ & $\begin{array}{l}92 \\
0,41967 \\
0,00456\end{array}$ & $\begin{array}{l}95 \\
0,64432\end{array}$ & 0,9565 \\
\hline \multirow{4}{*}{$\begin{array}{l}\text { PARÂMETROS } \\
\text { ESTIMADOS }\end{array}$} & VARIÁVEL & $\begin{array}{l}\text { GRAUS DE } \\
\text { LIBERDADE }\end{array}$ & $\begin{array}{l}\text { PARÂMETRO } \\
\text { ESTIMADO }\end{array}$ & $\begin{array}{l}\text { DESVIO } \\
\text { PADRĀO }\end{array}$ & $\begin{array}{l}\text { T PARA HO } \\
\text { Parâmetro=0 }\end{array}$ & $\begin{array}{l}\text { SIGNIFICÂNCIA } \\
\text { Valor de } \mathrm{P}\end{array}$ \\
\hline & $\begin{array}{l}\text { INTERCEPTO } \\
\text { D1 }\end{array}$ & $\begin{array}{l}1 \\
1\end{array}$ & $\begin{array}{r}0,194144 \\
-0,042304\end{array}$ & $\begin{array}{l}0,01759299 \\
0,01688504\end{array}$ & $\begin{array}{l}11,035 \\
-2,505\end{array}$ & $\begin{array}{l}0,0001 \\
0,0140\end{array}$ \\
\hline & D2 & 1 & $-0,007274$ & 0,01688504 & $-0,431$ & 0,6676 \\
\hline & IDADE & 1 & 0,01706 & 0,00038004 & 44,889 & 0,0001 \\
\hline
\end{tabular}

: Referencia para a Tabela 24. 
TABELA V (ANEXOV

PERCENTUAL, DE PESSOAS QUE RECEBEU ATENDIMENTO ODONTOLÓOICO

NO PERHODO DE UM ANO SEQUNDO IONDE E RENDA, COM O INTERNALO

DE CONFIANCA BRASIL. ZONA URBANA.(")

\begin{tabular}{|c|c|c|c|c|c|c|c|c|c|}
\hline \multirow[t]{2}{*}{ IDADE } & \multicolumn{3}{|c|}{ OA28.M. } & \multicolumn{3}{|c|}{$\begin{array}{l}\text { 3E48.M. } \\
\text { AT.ODONT INT. CONFU }\end{array}$} & \multicolumn{3}{|c|}{$\begin{array}{l}6 \mathrm{E}+\mathbf{8 . M} \\
\text { DON INT. CONF }\end{array}$} \\
\hline & & INF. & SUP. & & INF. & SUP. & & INF. & SUP. \\
\hline $\begin{array}{l}5 \\
6 \\
7 \\
8 \\
9\end{array}$ & $\begin{array}{l}0,50211 \\
0,49642 \\
0,49073 \\
0,48504 \\
0,47936\end{array}$ & $\begin{array}{l}0,46764 \\
0,45287 \\
0,44768 \\
0,44270 \\
0,43770\end{array}$ & $\begin{array}{l}0,54657 \\
0,54021 \\
0,53385 \\
0,52750 \\
0,52116\end{array}$ & $\begin{array}{l}0,62085 \\
0,61542 \\
0,60287 \\
0,60432 \\
0,50874\end{array}$ & $\begin{array}{l}0,57732 \\
0,57230 \\
0,56743 \\
0,56246 \\
0,55746\end{array}$ & $\begin{array}{l}0,68362 \\
0,65766 \\
0,65160 \\
0,64642 \\
0,603934\end{array}$ & $\begin{array}{l}0,77978 \\
0,77604 \\
0,77027 \\
0,76547 \\
0,76063\end{array}$ & $\begin{array}{l}0,74182 \\
0,73743 \\
0,73302 \\
0,72857 \\
0,72408\end{array}$ & $\begin{array}{l}0,81552 \\
0,81054 \\
0,80552 \\
0,80046 \\
0,78536\end{array}$ \\
\hline $\begin{array}{l}10 \\
11 \\
12 \\
13 \\
14\end{array}$ & $\begin{array}{l}0,47367 \\
0,46799 \\
0,46231 \\
0,46664 \\
0,46098\end{array}$ & $\begin{array}{l}0,43268 \\
0,42768 \\
0,42265 \\
0,41761 \\
0,41256\end{array}$ & $\begin{array}{l}0,51483 \\
0,60852 \\
0,50222 \\
0,49604 \\
0,48968\end{array}$ & $\begin{array}{l}0,58316 \\
0,68756 \\
0,58195 \\
0,67633 \\
0,67071\end{array}$ & $\begin{array}{l}0,65244 \\
0,54740 \\
0,54233 \\
0,53725 \\
0,53214\end{array}$ & $\begin{array}{l}0,63325 \\
0,62715 \\
0,62105 \\
0,61495 \\
0,60886\end{array}$ & $\begin{array}{l}0,76576 \\
0,76086 \\
0,74591 \\
0,74094 \\
0,73504\end{array}$ & $\begin{array}{l}0,71955 \\
0,71499 \\
0,71039 \\
0,70575 \\
0,70107\end{array}$ & $\begin{array}{l}0,79023 \\
0,78606 \\
0,77087 \\
0,77484 \\
0,76930\end{array}$ \\
\hline $\begin{array}{l}15 \\
16 \\
17 \\
18 \\
18\end{array}$ & $\begin{array}{l}0,44532 \\
0,43066 \\
0,43402 \\
0,42838 \\
0,42275\end{array}$ & $\begin{array}{l}0,40751 \\
0,40244 \\
0,39736 \\
0,39277 \\
0,38717\end{array}$ & $\begin{array}{l}0,48344 \\
0,47723 \\
0,47104 \\
0,46488 \\
0,45875\end{array}$ & $\begin{array}{l}0,56507 \\
0,55042 \\
0,55377 \\
0,54811 \\
0,54244\end{array}$ & $\begin{array}{l}0,62700 \\
0,52185 \\
0,61667 \\
0,61146 \\
0,50623\end{array}$ & $\begin{array}{l}0,60275 \\
0,50666 \\
0,50057 \\
0,58448 \\
0,57842\end{array}$ & $\begin{array}{l}0,73080 \\
0,72584 \\
0,72706 \\
0,71563 \\
0,71048\end{array}$ & $\begin{array}{l}0,68635 \\
0,69169 \\
0,68679 \\
0,68195 \\
0,67707\end{array}$ & $\begin{array}{l}0,76411 \\
0,75881 \\
0,76349 \\
0,74815 \\
0,74279\end{array}$ \\
\hline $\begin{array}{l}20 \\
21 \\
22 \\
23 \\
24\end{array}$ & $\begin{array}{l}0,41714 \\
0,41153 \\
0,40593 \\
0,40035 \\
0,39478\end{array}$ & $\begin{array}{l}0,38206 \\
0,37683 \\
0,37180 \\
0,36665 \\
0,36149\end{array}$ & $\begin{array}{l}0,46264 \\
0,44657 \\
0,44053 \\
0,43453 \\
0,42857\end{array}$ & $\begin{array}{l}0,53676 \\
0,53109 \\
0,52541 \\
0,51972 \\
0,51403\end{array}$ & $\begin{array}{l}0,50098 \\
0,49570 \\
0,49039 \\
0,48506 \\
0,47971\end{array}$ & $\begin{array}{l}0,57236 \\
0,56632 \\
0,56029 \\
0,55428 \\
0,54829\end{array}$ & $\begin{array}{l}0,70531 \\
0,70010 \\
0,68488 \\
0,88962 \\
0,68434\end{array}$ & $\begin{array}{l}0,67215 \\
0,66718 \\
0,66217 \\
0,65712 \\
0,65202\end{array}$ & $\begin{array}{l}0,73741 \\
0,73202 \\
0,72683 \\
0,72122 \\
0,71580\end{array}$ \\
\hline $\begin{array}{l}25 \\
28 \\
27 \\
28 \\
29\end{array}$ & $\begin{array}{l}0,38823 \\
0,38368 \\
0,37816 \\
0,37264 \\
0,36715\end{array}$ & $\begin{array}{l}0,36632 \\
0,36114 \\
0,34684 \\
0,34074 \\
0,33553\end{array}$ & $\begin{array}{l}0,42264 \\
0,41676 \\
0,41091 \\
0,40511 \\
0,39036\end{array}$ & $\begin{array}{l}0,50834 \\
0,50265 \\
0,49606 \\
0,49127 \\
0,48558\end{array}$ & $\begin{array}{l}0,47432 \\
0,46891 \\
0,46348 \\
0,45801 \\
0,45252\end{array}$ & $\begin{array}{l}0,64233 \\
0,63638 \\
0,53046 \\
0,62457 \\
0,61871\end{array}$ & $\begin{array}{l}0,67004 \\
0,67372 \\
0,66837 \\
0,60300 \\
0,65761\end{array}$ & $\begin{array}{l}0,84688 \\
0,61160 \\
0,63645 \\
0,63117 \\
0,62585\end{array}$ & $\begin{array}{l}0,71038 \\
0,70406 \\
0,60953 \\
0,68411 \\
0,68868\end{array}$ \\
\hline $\begin{array}{l}\mathbf{3 0} \\
\mathbf{3 1} \\
\mathbf{3 2} \\
33 \\
\mathbf{3 4}\end{array}$ & $\begin{array}{l}0,36167 \\
0,35821 \\
0,35077 \\
0,34535 \\
0,33095\end{array}$ & $\begin{array}{l}0,33030 \\
0,32507 \\
0,31283 \\
0,31457 \\
0,30832\end{array}$ & $\begin{array}{l}0,39364 \\
0,38728 \\
0,38236 \\
0,37679 \\
0,37127\end{array}$ & $\begin{array}{l}0,47890 \\
0,47421 \\
0,46853 \\
0,46285 \\
0,45718\end{array}$ & $\begin{array}{l}0,44701 \\
0,44147 \\
0,43590 \\
0,43031 \\
0,42470\end{array}$ & $\begin{array}{l}0,61287 \\
0,50707 \\
0,50129 \\
0,49565 \\
0,48885\end{array}$ & $\begin{array}{l}0,65220 \\
0,646777 \\
0,64132 \\
0,63585 \\
0,63037\end{array}$ & $\begin{array}{l}0,62048 \\
0,61506 \\
0,60959 \\
0,60408 \\
0,50852\end{array}$ & $\begin{array}{l}0,68326 \\
0,67785 \\
0,67244 \\
0,66704 \\
0,66165\end{array}$ \\
\hline $\begin{array}{l}35 \\
36 \\
37 \\
38 \\
39\end{array}$ & $\begin{array}{l}0,33457 \\
0,32921 \\
0,32387 \\
0,31858 \\
0,31327\end{array}$ & $\begin{array}{l}0,30405 \\
0,29879 \\
0,29351 \\
0,28824 \\
0,28297\end{array}$ & $\begin{array}{l}0,36579 \\
0,36037 \\
0,35499 \\
0,34968 \\
0,34438\end{array}$ & $\begin{array}{l}0,45161 \\
0,44585 \\
0,44020 \\
0,43455 \\
0,42891\end{array}$ & $\begin{array}{l}0,41806 \\
0,41340 \\
0,40772 \\
0,40202 \\
0,39630\end{array}$ & $\begin{array}{l}0,48417 \\
0,47854 \\
0,47293 \\
0,46737 \\
0,46184\end{array}$ & $\begin{array}{l}0,62486 \\
0,61935 \\
0,61381 \\
0,60828 \\
0,60270\end{array}$ & $\begin{array}{l}0,58292 \\
0,58728 \\
0,58169 \\
0,57585 \\
0,57008\end{array}$ & $\begin{array}{l}0,65627 \\
0,65080 \\
0,64555 \\
0,64020 \\
0,63488\end{array}$ \\
\hline $\begin{array}{l}40 \\
41 \\
42 \\
43 \\
44\end{array}$ & $\begin{array}{l}0,30800 \\
0,30276 \\
0,29754 \\
0,29235 \\
0,28719\end{array}$ & $\begin{array}{l}0,27769 \\
0,27242 \\
0,28716 \\
0,26180 \\
0,25644\end{array}$ & $\begin{array}{l}0,33916 \\
0,33398 \\
0,32885 \\
0,32377 \\
0,31873\end{array}$ & $\begin{array}{l}0,42329 \\
0,41767 \\
0,41206 \\
0,40646 \\
0,40088\end{array}$ & $\begin{array}{l}0,39057 \\
0,38482 \\
0,37905 \\
0,37327 \\
0,36749\end{array}$ & $\begin{array}{l}0,45635 \\
0,46089 \\
0,44647 \\
0,44009 \\
0,43474\end{array}$ & $\begin{array}{l}0,58713 \\
0,59154 \\
0,58504 \\
0,58032 \\
0,57470\end{array}$ & $\begin{array}{l}0,56428 \\
0,56840 \\
0,66251 \\
0,54657 \\
0,54060\end{array}$ & $\begin{array}{l}0,62958 \\
0,62428 \\
0,61897 \\
0,61370 \\
0,60845\end{array}$ \\
\hline $\begin{array}{l}45 \\
46 \\
47 \\
48 \\
49\end{array}$ & $\begin{array}{l}0,28205 \\
0,27694 \\
0,27187 \\
0,26682 \\
0,28180\end{array}$ & $\begin{array}{l}0,25140 \\
0,24617 \\
0,24096 \\
0,23576 \\
0,23057\end{array}$ & $\begin{array}{l}0,31375 \\
0,30881 \\
0,30382 \\
0,29907 \\
0,29427\end{array}$ & $\begin{array}{l}0,39531 \\
0,38975 \\
0,38421 \\
0,37868 \\
0,37317\end{array}$ & $\begin{array}{l}0,36168 \\
0,36589 \\
0,36008 \\
0,34427 \\
0,33846\end{array}$ & $\begin{array}{l}0,42943 \\
0,42415 \\
0,41891 \\
0,41371 \\
0,40854\end{array}$ & $\begin{array}{l}0,56907 \\
0,56343 \\
0,56778 \\
0,55213 \\
0,54646\end{array}$ & $\begin{array}{l}0,53460 \\
0,52586 \\
0,52250 \\
0,51640 \\
0.51027\end{array}$ & $\begin{array}{l}0,60231 \\
0,59799 \\
0,59278 \\
0,58759 \\
0,58241\end{array}$ \\
\hline $\begin{array}{l}50 \\
51 \\
52 \\
53 \\
54\end{array}$ & $\begin{array}{l}0,25681 \\
0,25185 \\
0,24693 \\
0,24204 \\
0,23718\end{array}$ & $\begin{array}{l}0,22541 \\
0,22027 \\
0,21516 \\
0,21007 \\
0,20501\end{array}$ & $\begin{array}{l}0,28952 \\
0,28481 \\
0,28014 \\
0,27551 \\
0,27083\end{array}$ & $\begin{array}{l}0,36767 \\
0,36218 \\
0,35673 \\
0,35129 \\
0,34586\end{array}$ & $\begin{array}{l}0,33265 \\
0,32685 \\
0,32104 \\
0,31525 \\
0,30947\end{array}$ & $\begin{array}{l}0,40340 \\
0,39830 \\
0,30323 \\
0,38819 \\
0,38319\end{array}$ & $\begin{array}{l}0,54079 \\
0,53512 \\
0,62944 \\
0,52376 \\
0,61807\end{array}$ & $\begin{array}{l}0,50412 \\
0,49795 \\
0,49175 \\
0,48553 \\
0,47930\end{array}$ & $\begin{array}{l}0,57724 \\
0,57210 \\
0,56696 \\
0,56184 \\
0,55674\end{array}$ \\
\hline $\begin{array}{l}55 \\
56 \\
57 \\
58 \\
59\end{array}$ & $\begin{array}{l}0,23235 \\
0,22757 \\
0,22281 \\
0,21809 \\
0,21341\end{array}$ & $\begin{array}{l}0,19998 \\
0,19498 \\
0,19001 \\
0,18508 \\
0,18019\end{array}$ & $\begin{array}{l}0,26639 \\
0,28189 \\
0,25743 \\
0,25301 \\
0,24864\end{array}$ & $\begin{array}{l}0,34046 \\
0,33508 \\
0,32971 \\
0,32438 \\
0,31906\end{array}$ & $\begin{array}{l}0,30370 \\
0,29794 \\
0,20219 \\
0,26847 \\
0,28076\end{array}$ & $\begin{array}{l}0,37821 \\
0,37327 \\
0,36836 \\
0,36348 \\
0,35862\end{array}$ & $\begin{array}{l}0,51238 \\
0,60669 \\
0,60100 \\
0,49531 \\
0,48962\end{array}$ & $\begin{array}{l}0,47304 \\
0,46678 \\
0,46050 \\
0,45420 \\
0,44780\end{array}$ & $\begin{array}{l}0,55165 \\
0,54657 \\
0,54150 \\
0,53645 \\
0,53141\end{array}$ \\
\hline $\begin{array}{l}60 \\
61 \\
62 \\
63 \\
64\end{array}$ & $\begin{array}{l}0,20877 \\
0,20416 \\
0,10950 \\
0,19506 \\
0,18057\end{array}$ & $\begin{array}{l}0,17534 \\
0,17053 \\
0,16576 \\
0,16103 \\
0,15635\end{array}$ & $\begin{array}{l}0,24430 \\
0,24000 \\
0,23573 \\
0,23161 \\
0,22732\end{array}$ & $\begin{array}{l}0,31377 \\
0,30850 \\
0,30325 \\
0,20803 \\
0,29284\end{array}$ & $\begin{array}{l}0,27507 \\
0,26981 \\
0,26377 \\
0,25816 \\
0,25257\end{array}$ & $\begin{array}{l}0,35380 \\
0,34001 \\
0,34425 \\
0,33061 \\
0,33480\end{array}$ & $\begin{array}{l}0,48393 \\
0,47825 \\
0,47256 \\
0,46688 \\
0,46121\end{array}$ & $\begin{array}{r}0,44160 \\
0,43528 \\
0,42896 \\
0,42284 \\
\ldots . . . .\end{array}$ & $\begin{array}{l}0,52639 \\
0,52137 \\
0,51637 \\
0,51138 \\
0,50641\end{array}$ \\
\hline $\begin{array}{l}65 \\
66 \\
67 \\
68 \\
69\end{array}$ & $\begin{array}{l}0,18612 \\
0,18171 \\
0,17734 \\
0,17302 \\
0,16873\end{array}$ & $\begin{array}{l}0,15172 \\
0,14714 \\
0,14260 \\
0,13812 \\
0,13369\end{array}$ & $\begin{array}{l}0,22318 \\
0,21006 \\
0,21499 \\
0,21095 \\
0,20695\end{array}$ & $\begin{array}{l}0,28767 \\
0,28254 \\
0,27743 \\
0,27234 \\
0,28729\end{array}$ & $\begin{array}{l}0,24702 \\
0,24149 \\
0,23600 \\
0,23055 \\
0,22513\end{array}$ & $\begin{array}{l}0,33013 \\
0,32548 \\
0,32085 \\
0,31626 \\
0,31169\end{array}$ & $\begin{array}{l}0,45654 \\
0,44087 \\
0,44421 \\
0,43856 \\
0,43292\end{array}$ & $\begin{array}{l}0,41001 \\
0,40309 \\
0,39738 \\
0,39108 \\
0,38478\end{array}$ & $\begin{array}{l}0,50144 \\
0,49649 \\
0,49165 \\
0,48662 \\
0,48170\end{array}$ \\
\hline $\begin{array}{l}70 \\
71 \\
72 \\
73 \\
74\end{array}$ & $\begin{array}{l}0,18451 \\
0,16040 \\
0,15639 \\
0,15248 \\
0,14867\end{array}$ & $\begin{array}{l}0,12930 \\
0,12511 \\
0,12105 \\
0,11710 \\
0,11343\end{array}$ & $\begin{array}{l}0,20302 \\
0,19916 \\
0,19538 \\
0,19168 \\
0,18802\end{array}$ & $\begin{array}{l}0,26248 \\
0,25776 \\
0,25311 \\
0,24856 \\
0,24408\end{array}$ & $\begin{array}{l}0,21006 \\
0,21406 \\
0,21008 \\
0,20531 \\
0,20063\end{array}$ & $\begin{array}{l}0,30717 \\
0,30272 \\
0,29833 \\
0,29400 \\
0,28974\end{array}$ & $\begin{array}{l}0,42720 \\
0,42714 \\
0,41625 \\
0,41084 \\
0,40550\end{array}$ & $\begin{array}{l}0,37001 \\
0,37282 \\
0,36713 \\
0,36113 \\
0,35562\end{array}$ & $\begin{array}{l}0,47888 \\
0,47211 \\
0,46739 \\
0,46272 \\
0,45809\end{array}$ \\
\hline $\begin{array}{l}75 \\
76 \\
77 \\
78 \\
79 \\
\end{array}$ & $\begin{array}{l}0,14668 \\
0,14075 \\
0,13695 \\
0,13325 \\
0,12965 \\
\end{array}$ & $\begin{array}{l}0,11087 \\
0,10542 \\
0,10175 \\
0,98070 \\
0,94510\end{array}$ & $\begin{array}{l}0,18428 \\
0,18057 \\
0,17696 \\
0,17342 \\
0,16995\end{array}$ & $\begin{array}{l}0,23944 \\
0,23489 \\
0,23043 \\
0,22605 \\
0,22176 \\
\end{array}$ & $\begin{array}{l}0,19586 \\
0,19120 \\
0,18688 \\
0,18242 \\
0,17807 \\
\end{array}$ & $\begin{array}{l}0,28525 \\
0,28083 \\
0,27647 \\
0,27218 \\
0,26797 \\
\end{array}$ & $\begin{array}{l}0,30282 \\
0,39422 \\
0,38871 \\
0,38326 \\
0,37780 \\
\end{array}$ & $\begin{array}{l}0,34944 \\
0,34376 \\
0,33818 \\
0,33229 \\
0,32688 \\
\end{array}$ & $\begin{array}{l}0,45351 \\
0,44898 \\
0,44449 \\
0,44004 \\
0,43564 \\
\end{array}$ \\
\hline
\end{tabular}

$\because$ Reteróncia para a Tabola 29. 
TABELA VII (ANEXO V)

ANÁLISE DE VARIÁNCIA E PARÁMETROS ESTIMADOS

PARA OS VALORES DA TABELA 29-A: PROCURA DE

ATENDIMENTO ODONTOLOGICO.(")

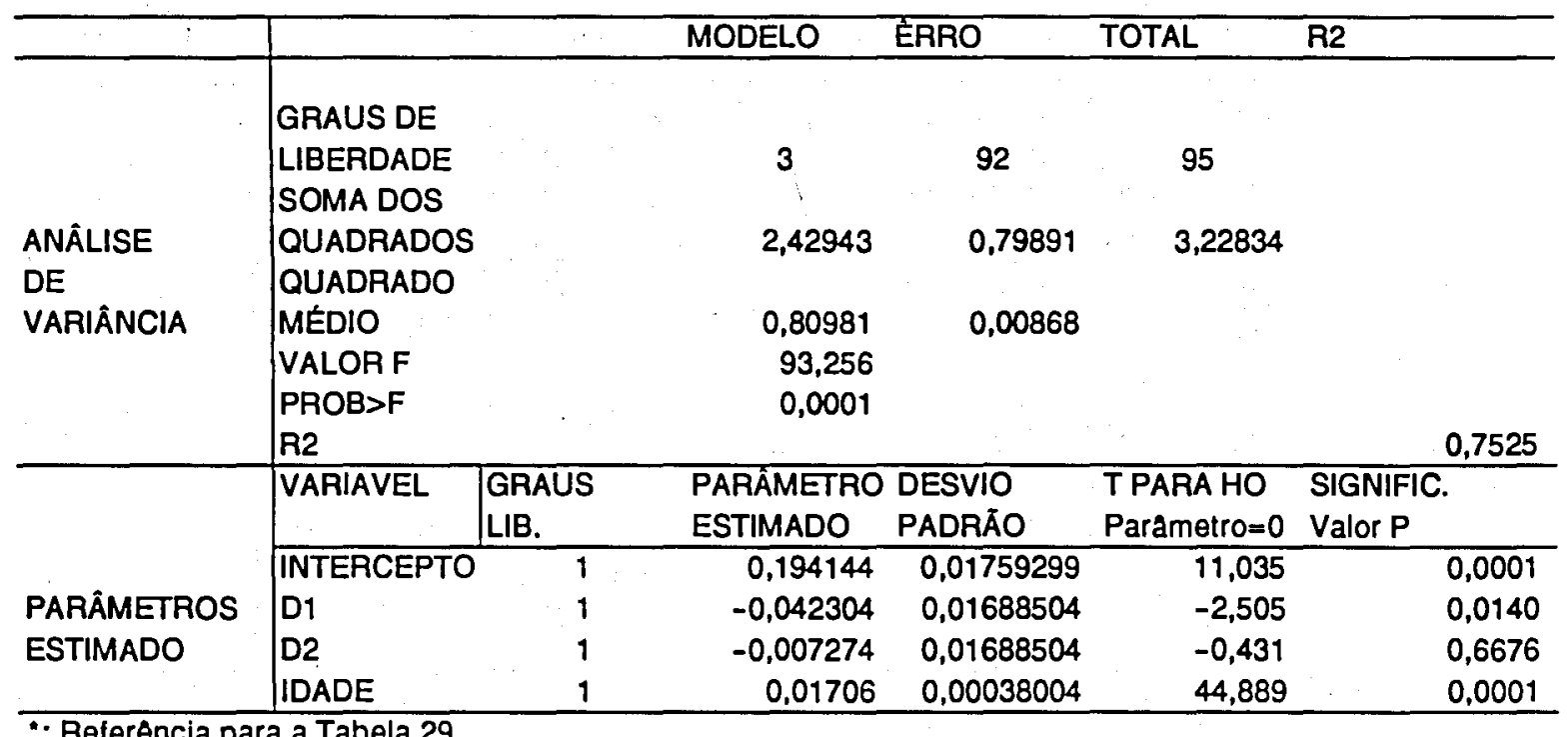

: Referencia para a Tabela 29. 
TABELA VIII (ANEXO V)

PERCENTUAL DE PESSOAS UIVES DE PRÓTESE TOTAL

SEQUNDO IDADE E RENDA COM OS INTERNALOS DE CONFIANGGA.(")

\begin{tabular}{|c|c|c|c|c|c|c|c|c|c|}
\hline \multirow{3}{*}{ IDADE } & \multicolumn{3}{|c|}{ O A 2 S.M. } & \multirow{2}{*}{\multicolumn{3}{|c|}{$\begin{array}{c}\text { 3EA S.M. } \\
\text { AT.ODONT INT.CONFIANCA }\end{array}$}} & \multicolumn{3}{|c|}{$5 E+3 . M$} \\
\hline & \multirow[t]{2}{*}{ AT.ODONT. } & \multicolumn{2}{|c|}{ INT.CONFIANCAA } & & & & \multirow[t]{2}{*}{ AT.ODON } & \multicolumn{2}{|c|}{ INT.CONFIANCA } \\
\hline & & INF. & SUP. & AT.ODONT & INF. & SUP. & & INF. & sup. \\
\hline $\begin{array}{l}15 \\
16 \\
17 \\
18 \\
19\end{array}$ & $\begin{array}{l}0,97400 \\
0,96587 \\
0,25669 \\
0,24647 \\
0,93524\end{array}$ & $\begin{array}{l}0,95874 \\
0,95021 \\
0,93971 \\
0,02827 \\
0,91592\end{array}$ & $\begin{array}{l}0,98521 \\
0,97867 \\
0,97097 \\
0,06214 \\
0,95219\end{array}$ & $\begin{array}{l}0,98326 \\
0,98880 \\
0,98323 \\
0,97656 \\
0,96881\end{array}$ & $\begin{array}{l}0,88513 \\
0,97905 \\
0,97194 \\
0,86383 \\
0,85472\end{array}$ & $\begin{array}{l}0,89822 \\
0,09554 \\
0,99166 \\
0,88659 \\
0,88304\end{array}$ & $\begin{array}{l}0,99823 \\
0,99967 \\
0,99997 \\
0,99913 \\
0,99716\end{array}$ & $\begin{array}{l}0,89327 \\
0,89956 \\
0,99806 \\
0,89550 \\
0,99189\end{array}$ & $\begin{array}{l}1,00000 \\
0,99760 \\
0,99892 \\
0,99993 \\
0,89973\end{array}$ \\
\hline $\begin{array}{l}20 \\
21 \\
22 \\
23 \\
24\end{array}$ & $\begin{array}{l}0,02301 \\
0,80983 \\
0,89571 \\
0,88070 \\
0,86482\end{array}$ & $\begin{array}{l}0,80266 \\
0,88854 \\
0,87357 \\
0,85778 \\
0,84121\end{array}$ & $\begin{array}{l}0,94116 \\
0,92907 \\
0,91596 \\
0,90186 \\
0,88680\end{array}$ & $\begin{array}{l}0,95899 \\
0,95013 \\
0,93924 \\
0,92736 \\
0,91450\end{array}$ & $\begin{array}{l}0,94464 \\
0,93360 \\
0,92162 \\
0,80872 \\
0,82494\end{array}$ & $\begin{array}{l}0,87294 \\
0,06440 \\
0,95475 \\
0,84402 \\
0,80222\end{array}$ & $\begin{array}{l}0,99841 \\
0,98984 \\
0,98451 \\
0,97807 \\
0,87055\end{array}$ & $\begin{array}{l}0,98723 \\
0,98152 \\
0,97477 \\
0,96701 \\
0,95823\end{array}$ & $\begin{array}{l}0,99832 \\
0,99571 \\
0,99180 \\
0,98692 \\
0,88077\end{array}$ \\
\hline $\begin{array}{l}25 \\
26 \\
27 \\
28 \\
29\end{array}$ & $\begin{array}{l}0,84811 \\
0,83081 \\
0,81236 \\
0,78340 \\
0,77377\end{array}$ & $\begin{array}{l}0,82389 \\
0,80585 \\
0,78712 \\
0,76765 \\
0,74777\end{array}$ & $\begin{array}{l}0,87084 \\
0,85401 \\
0,83635 \\
0,81791 \\
0,78875\end{array}$ & $\begin{array}{l}0,80071 \\
0,88600 \\
0,87042 \\
0,85399 \\
0,83676\end{array}$ & $\begin{array}{l}0,88029 \\
0,86480 \\
0,84851 \\
0,83143 \\
0,81362\end{array}$ & $\begin{array}{l}0,81941 \\
0,80561 \\
0,89085 \\
0,87518 \\
0,85865\end{array}$ & $\begin{array}{l}0,96195 \\
0,95231 \\
0,94164 \\
0,82997 \\
0,91732\end{array}$ & $\begin{array}{l}0,84845 \\
0,83770 \\
0,82589 \\
0,81333 \\
0,89977\end{array}$ & $\begin{array}{l}0,97348 \\
0,96506 \\
0,95554 \\
0,84495 \\
0,93332\end{array}$ \\
\hline $\begin{array}{l}30 \\
31 \\
32 \\
33 \\
34\end{array}$ & $\begin{array}{l}0,75352 \\
0,73289 \\
0,71134 \\
0,68950 \\
0,66723\end{array}$ & $\begin{array}{l}0,72722 \\
0,70615 \\
0,68459 \\
0,66258 \\
0,64018\end{array}$ & $\begin{array}{l}0,77890 \\
0,75842 \\
0,73737 \\
0,71578 \\
0,69374\end{array}$ & $\begin{array}{l}0,81876 \\
0,80004 \\
0,78064 \\
0,76060 \\
0,73997\end{array}$ & $\begin{array}{l}0,79509 \\
0,77580 \\
0,76606 \\
0,73563 \\
0,71465\end{array}$ & $\begin{array}{l}0,84128 \\
0,82314 \\
0,80428 \\
0,78470 \\
0,76451\end{array}$ & $\begin{array}{l}0,90372 \\
0,88920 \\
0,87380 \\
0,85755 \\
0,84049\end{array}$ & $\begin{array}{l}0,88531 \\
0,86999 \\
0,85383 \\
0,83687 \\
0,81913\end{array}$ & $\begin{array}{l}0,92068 \\
0,90706 \\
0,89251 \\
0,87706 \\
0,86075\end{array}$ \\
\hline $\begin{array}{l}35 \\
36 \\
37 \\
38 \\
39\end{array}$ & $\begin{array}{l}0,64459 \\
0,62161 \\
0,59836 \\
0,57489 \\
0,55124\end{array}$ & $\begin{array}{l}0,61744 \\
0,59439 \\
0,57108 \\
0,64757 \\
0,52392\end{array}$ & $\begin{array}{l}0,67128 \\
0,64846 \\
0,62534 \\
0,60198 \\
0,57842\end{array}$ & $\begin{array}{l}0,71879 \\
0,69712 \\
0,67489 \\
0,65427 \\
0,62961\end{array}$ & $\begin{array}{l}0,69315 \\
0,67119 \\
0,64880 \\
0,62604 \\
0,60285\end{array}$ & $\begin{array}{l}0,74373 \\
0,72243 \\
0,70065 \\
0,67844 \\
0,65587\end{array}$ & $\begin{array}{l}0,82265 \\
0,80408 \\
0,78482 \\
0.76492 \\
0,74441\end{array}$ & $\begin{array}{l}0,80066 \\
0,78148 \\
0,76164 \\
0,74118 \\
0,72014\end{array}$ & $\begin{array}{l}0,84363 \\
0,82574 \\
0,80713 \\
0,78785 \\
0,76794\end{array}$ \\
\hline $\begin{array}{l}40 \\
41 \\
42 \\
43 \\
44\end{array}$ & $\begin{array}{l}0,52748 \\
0,50368 \\
0,47983 \\
0,45604 \\
0,43235\end{array}$ & $\begin{array}{l}0,50016 \\
0,47635 \\
0,45255 \\
0,42882 \\
0,40520\end{array}$ & $\begin{array}{l}0,55473 \\
0,53096 \\
0,50716 \\
0,48340 \\
0,45972\end{array}$ & $\begin{array}{l}0,60645 \\
0,58304 \\
0,55945 \\
0,53572 \\
0,51192\end{array}$ & $\begin{array}{l}0,67959 \\
0,55599 \\
0,53223 \\
0,50834 \\
0,48439\end{array}$ & $\begin{array}{l}0,63299 \\
0,60984 \\
0,58649 \\
0,56300 \\
0,53040\end{array}$ & $\begin{array}{l}0,72334 \\
0,70177 \\
0,67974 \\
0,65730 \\
0,63450\end{array}$ & $\begin{array}{l}0,68856 \\
0,67649 \\
0,65397 \\
0,63108 \\
0,60780\end{array}$ & $\begin{array}{l}0,74746 \\
0,72645 \\
0,70497 \\
0,68308 \\
0,66079\end{array}$ \\
\hline $\begin{array}{l}45 \\
46 \\
47 \\
48 \\
49\end{array}$ & $\begin{array}{l}0,40882 \\
0,38550 \\
0,36243 \\
0,33868 \\
0,31729\end{array}$ & $\begin{array}{l}0,38175 \\
0.35864 \\
0.33561 \\
0.31302 \\
0,29083\end{array}$ & $\begin{array}{l}0,43617 \\
0,41281 \\
0,38969 \\
0,36685 \\
0,34435\end{array}$ & $\begin{array}{l}0,48808 \\
0,46427 \\
0,44055 \\
0,41695 \\
0,39355\end{array}$ & $\begin{array}{l}0,46043 \\
0,43652 \\
0,41271 \\
0,38907 \\
0,38564\end{array}$ & $\begin{array}{l}0,51576 \\
0,49213 \\
0,46857 \\
0,44511 \\
0,42182\end{array}$ & $\begin{array}{l}0,61140 \\
0,68804 \\
0,56448 \\
0,64078 \\
0,51809\end{array}$ & $\begin{array}{l}0,58425 \\
0,66046 \\
0,53649 \\
0,51239 \\
0,48823\end{array}$ & $\begin{array}{l}0,63820 \\
0,61534 \\
0,59227 \\
0,66904 \\
0,54569\end{array}$ \\
\hline $\begin{array}{l}50 \\
51 \\
52 \\
53 \\
54\end{array}$ & $\begin{array}{l}0,29532 \\
0,27381 \\
0,25282 \\
0,23238 \\
0,21256\end{array}$ & $\begin{array}{l}0,26910 \\
0,24787 \\
0.22720 \\
0.20715 \\
0,18777\end{array}$ & $\begin{array}{l}0,32224 \\
0,30054 \\
0.27932 \\
0,25881 \\
0,23846\end{array}$ & $\begin{array}{l}0,37039 \\
0,34752 \\
0,32500 \\
0,30288 \\
0,28121\end{array}$ & $\begin{array}{l}0,34248 \\
0,31266 \\
0,29724 \\
0,27525 \\
0,25377\end{array}$ & $\begin{array}{l}0,39873 \\
0,37591 \\
0,35340 \\
0,33124 \\
0,30248\end{array}$ & $\begin{array}{l}0,49315 \\
0,46833 \\
0,44659 \\
0,42196 \\
0,38851\end{array}$ & $\begin{array}{l}0,46405 \\
0.43991 \\
0,41558 \\
0.39202 \\
0,36838\end{array}$ & $\begin{array}{l}0,52208 \\
0,49888 \\
0,47548 \\
0,45219 \\
0,42804\end{array}$ \\
\hline $\begin{array}{l}55 \\
56 \\
57 \\
58 \\
59\end{array}$ & $\begin{array}{l}0,19339 \\
0,17492 \\
0,15718 \\
0,14022 \\
0,12409\end{array}$ & $\begin{array}{l}0.16910 \\
0.15120 \\
0.13411 \\
0.11788 \\
0.10254\end{array}$ & $\begin{array}{l}0,21880 \\
0,19997 \\
0,18172 \\
0,16418 \\
0,14737\end{array}$ & $\begin{array}{l}0,26003 \\
0,23940 \\
0,21936 \\
0,19995 \\
0,18123\end{array}$ & $\begin{array}{l}0,23285 \\
0,21254 \\
0,19289 \\
0,17396 \\
0,15578\end{array}$ & $\begin{array}{l}0,28810 \\
0,26733 \\
0,24702 \\
0,22729 \\
0,20816\end{array}$ & $\begin{array}{l}0,37530 \\
0,35236 \\
0,32976 \\
0,30755 \\
0,28578\end{array}$ & $\begin{array}{l}0,34502 \\
0,32200 \\
0,29938 \\
0,27721 \\
0,25556\end{array}$ & $\begin{array}{l}0,40607 \\
0,38333 \\
0,36088 \\
0,33875 \\
0,31699\end{array}$ \\
\hline $\begin{array}{l}60 \\
61 \\
62 \\
63 \\
64\end{array}$ & $\begin{array}{l}0,10880 \\
0,09441 \\
0,08093 \\
0,06841 \\
0,05687\end{array}$ & $\begin{array}{l}0.08815 \\
0,07473 \\
0.06233 \\
0.05098 \\
0,04070\end{array}$ & $\begin{array}{l}0,13134 \\
0,11611 \\
0,10172 \\
0,08819 \\
0,07555\end{array}$ & $\begin{array}{l}0,16324 \\
0,14601 \\
0,12958 \\
0,11400 \\
0,09929\end{array}$ & $\begin{array}{l}0,13842 \\
0,12191 \\
0,11063 \\
0,09162 \\
0,07793\end{array}$ & $\begin{array}{l}0,18868 \\
0,17188 \\
0,16480 \\
0,13847 \\
0,12292\end{array}$ & $\begin{array}{l}0,26449 \\
0,24374 \\
0,22357 \\
0,20403 \\
0,18516\end{array}$ & $\begin{array}{l}0,23447 \\
0,21400 \\
0,19421 \\
0,17513 \\
0,15683\end{array}$ & $\begin{array}{l}0,29565 \\
0,27476 \\
0,25438 \\
0,23453 \\
0,21527\end{array}$ \\
\hline $\begin{array}{l}65 \\
66 \\
67 \\
68 \\
69\end{array}$ & $\begin{array}{l}0.04634 \\
0.03683 \\
0,02838 \\
0.02101 \\
0.01472\end{array}$ & $\begin{array}{l}0.03153 \\
0,02349 \\
0,01661 \\
0.01089 \\
0,00637\end{array}$ & $\begin{array}{l}0,06382 \\
0,05302 \\
0,04318 \\
0,03432 \\
0,02644\end{array}$ & $\begin{array}{l}0,08549 \\
0,07264 \\
0,06076 \\
0.04987 \\
0,04001\end{array}$ & $\begin{array}{l}0,06525 \\
0,05361 \\
0,04305 \\
0,03360 \\
0,02527\end{array}$ & $\begin{array}{l}0,10819 \\
0,09430 \\
0,08128 \\
0,06915 \\
0,05794\end{array}$ & $\begin{array}{l}0,16701 \\
0,14961 \\
0,13301 \\
0,11724 \\
0,10234\end{array}$ & $\begin{array}{l}0,13935 \\
0,12273 \\
0,10701 \\
0,09225 \\
0,07848\end{array}$ & $\begin{array}{l}0,19663 \\
0,17865 \\
0,16136 \\
0,14479 \\
0,12899\end{array}$ \\
\hline $\begin{array}{l}70 \\
71 \\
72 \\
73 \\
74\end{array}$ & $\begin{array}{l}0,01001 \\
0,00661 \\
0,00429 \\
0,00270 \\
0,00165\end{array}$ & $\begin{array}{l}0,00433 \\
0,00286 \\
0,00186 \\
0.00117 \\
0,00071\end{array}$ & $\begin{array}{l}0,01798 \\
0,01187 \\
0,00771 \\
0,00486 \\
0,00296\end{array}$ & $\begin{array}{l}0,03161 \\
0,02434 \\
0,01825 \\
0.01351 \\
0,00972\end{array}$ & $\begin{array}{l}0,01996 \\
0,01537 \\
0,01153 \\
0,00853 \\
0,00814\end{array}$ & $\begin{array}{l}0,04577 \\
0,03524 \\
0,02643 \\
0,01956 \\
0,01408\end{array}$ & $\begin{array}{l}0,08698 \\
0,07307 \\
0,06065 \\
0,04973 \\
0,04028\end{array}$ & $\begin{array}{l}0,06670 \\
0,05602 \\
0,04650 \\
0,03813 \\
0,03088\end{array}$ & $\begin{array}{l}0,10964 \\
0,09210 \\
0,07644 \\
0,08268 \\
0,05077\end{array}$ \\
\hline $\begin{array}{l}75 \\
76 \\
77 \\
78 \\
79\end{array}$ & $\begin{array}{l}0,00099 \\
0,00057 \\
0,00032 \\
0,00018 \\
0.00009\end{array}$ & $\begin{array}{l}0.00043 \\
0.00025 \\
0,00014 \\
0,00008 \\
0.00004\end{array}$ & $\begin{array}{l}0,00178 \\
0,00103 \\
0,00058 \\
0,00032 \\
0,00016\end{array}$ & $\begin{array}{l}0.00681 \\
0.00470 \\
0,00315 \\
0,00208 \\
0.00135 \\
\end{array}$ & $\begin{array}{l}0,00430 \\
0.00297 \\
0,00189 \\
0,00131 \\
0.00085 \\
\end{array}$ & $\begin{array}{l}0,00886 \\
0,00880 \\
0,00456 \\
0,00300 \\
0,00195\end{array}$ & $\begin{array}{l}0,03243 \\
0,02594 \\
0,02049 \\
0,01698 \\
0,01558 \\
\end{array}$ & $\begin{array}{l}0,02486 \\
0,01889 \\
0,01571 \\
0,01225 \\
0,00931 \\
\end{array}$ & $\begin{array}{l}0,04087 \\
0,03270 \\
0,02583 \\
0,02015 \\
0,01531 \\
\end{array}$ \\
\hline
\end{tabular}

(") Roferóncia para a tabela 30 
TABELA IX (ANEXO V)

ANÁLISE DE VARIÂNCIA E PARÂMETROS ESTIMADOS

PARA OS VALORES DA TABELA VIII: PESSOAS

LIVRES DE PRÓTESE TOTAL.(*)

\begin{tabular}{|c|c|c|c|c|c|c|c|}
\hline & & & MODELO & ÉRRO & TOTAL & $\mathrm{R} 2$ & \\
\hline & GRAUS DE & & & & & & \\
\hline & LIBERDADE & & 3 & 71 & 74 & & \\
\hline & SOMA DOS & & & & & & \\
\hline ANÁLISE & QUADRADOS & & 8,88149 & 0,33314 & 9,21462 & & \\
\hline DE & QUADRADO & & & & & & \\
\hline VARIÂNCIA & MEDIO & & 2,9605 & 0,00469 & & & \\
\hline & VALOR F & & 630,961 & & & & \\
\hline & $P R O B>F$ & & 0,0001 & & & & \\
\hline & R2 & & & & & & 0,9638 \\
\hline & VARIÁVEL & GRAUS & PARÁMETRO & DESVIO & TPARA HO & SIGNIF. & \\
\hline & & LIB. & ESTIMADO & PADRÃO & Parâmetro $=0$ & Valor $\mathrm{P}$ & \\
\hline & INTERCEPTO & 1 & 1,970422 & 0,02691161 & 73,218 & & 0,0001 \\
\hline PARAMETROS & D1 & 1 & $-0,020403$ & 0,0193743 & $-10,531$ & & 0,0001 \\
\hline ESTIMADOS & D2 & 1 & $-0,12426$ & 0,0193743 & $-6,414$ & & 0,0001 \\
\hline & IDADE & 1 & $-0,023837$ & 0.00056497 & $-42,193$ & & 0,0001 \\
\hline
\end{tabular}

$\because$ Referencia para a Tabela 30. 
TABELAX (ANEXOV

PERCENTUAL DE PESSOAS EDENTULAS, SEQUNDO O ICNTP, POR IDADE

E RENDA, COM OS INTERVALOS DE CONFUNCA. BRASIL, ZONA URBANA(")

\begin{tabular}{|c|c|c|c|c|c|c|c|c|c|}
\hline IOADE & $\%$ & $\begin{array}{l}\text { OA.2S.M. } \\
\text { INT.CONFIA } \\
\text { INF. }\end{array}$ & $\begin{array}{l}\text { NCAA } \\
\text { SUP. }\end{array}$ & $\%$ & $\begin{array}{l}3 \text { E } 4 \text { S.M. } \\
\text { INT.CONFIAN } \\
\text { INF. }\end{array}$ & GA. & $\%$ & $\begin{array}{l}\text { SE + S.M } \\
\text { INT.CONFU } \\
\text { INF. }\end{array}$ & $\begin{array}{l}\text { ANCA } \\
\text { SUP. }\end{array}$ \\
\hline 15 & 0,00136 & 0,00053 & 0,00476 & 0,00002 & 0,00001 & 0.00004 & 0,00000 & 0,00000 & 0,00001 \\
\hline 16 & 0,00310 & 0,00048 & 0,00836 & 0,00056 & 0,00013 & 0,00345 & 0,00000 & 0,00000 & 0,00001 \\
\hline 17 & 0,00578 & 0,00174 & 0,01215 & 0,00187 & 0,00048 & 0,00602 & 0,00000 & 0,00000 & 0,00002 \\
\hline 18 & 0,00913 & 0,00384 & 0,01664 & 0,00395 & 0,00085 & 0,00829 & 0,00000 & 0,00000 & 0,00003 \\
\hline 19 & 0,01323 & 0,00676 & 0,02183 & $0,0067 \theta$ & 0,00245 & 0,01327 & 0,00001 & 0,00000 & 0,00004 \\
\hline 20 & 0,01800 & 0,01049 & 0,02770 & 0,01038 & 0,00486 & 0,01786 & 0,00020 & 0,00001 & 0,00008 \\
\hline 21 & 0,02568 & 0,01601 & 0,03428 & 0,01473 & 0,00808 & 0,02333 & 0,00008 & 0,00003 & 0,00013 \\
\hline 22 & 0,03001 & 0,02033 & 0.04160 & 0,01983 & 0,01211 & 0.02940 & 0,00052 & 0,00007 & 0,00290 \\
\hline 23 & 0,03706 & 0,02842 & 0,04940 & 0,02568 & 0,01682 & 0,03816 & 0.00180 & 0.00014 & 0,00530 \\
\hline 24 & 0,04482 & 0,03329 & 0,05797 & 0,03223 & 0,02253 & 0,04359 & 0,00385 & 0,00104 & 0,00842 \\
\hline 25 & 0,05328 & 0,04080 & 0.08718 & 0,03951 & 0,02890 & 0,05169 & 0,00665 & 0,00274 & 0,01228 \\
\hline 28 & 0,06242 & 0,04925 & 0.07704 & 0,04750 & 0,03603 & 0,06046 & 0,01022 & 0.00525 & 0,01680 \\
\hline 27 & 0,07224 & 0,05832 & 0,08762 & 0,05018 & 0,04390 & 0,06987 & 0.01454 & 0,00850 & 0,02206 \\
\hline 28 & 0,08272 & 0,06809 & 0,08862 & 0,06555 & 0,05250 & 0,07003 & 0.01060 & 0,01268 & 0.02802 \\
\hline 29 & 0,09383 & 0,07855 & 0,11033 & 0,07658 & 0,08181 & 0,00062 & 0,02541 & 0,01754 & 0,03460 \\
\hline 30 & 0.10567 & 0,08068 & 0,12262 & 0,08627 & 0,07181 & 0,10102 & 0.03184 & 0,02318 & 0,04204 \\
\hline 31 & 0,11702 & 0,10142 & 0,13550 & 0,00750 & 0,08260 & 0,11383 & 0,03019 & 0,02058 & 0,05009 \\
\hline 32 & 0,13086 & 0,11379 & 0.14803 & 0,10953 & 0,09370 & 0,12033 & 0,04715 & 0,03872 & 0,05881 \\
\hline 33 & 0,14436 & 0,12875 & 0.16291 & 0,12207 & 0,10574 & 0,13041 & 0.05581 & 0,04459 & 0,08820 \\
\hline 34 & 0,15841 & 0,14029 & 0,17741 & 0,13520 & 0,11829 & 0,15305 & 0,06515 & 0,05318 & 0,07825 \\
\hline 35 & 0,17298 & 0,16436 & 0,19243 & 0,14888 & 0,13141 & 0,16724 & 0,07515 & 0,06242 & 0,08886 \\
\hline 36 & 0,18808 & 0,18806 & 0,20703 & 0,16310 & 0,14510 & 0,18105 & 0,08581 & 0,07236 & 0,10030 \\
\hline 37 & 0,20361 & 0,18404 & 0,22391 & 0,17784 & 0,16801 & 0,19717 & 0.09711 & 0,08294 & 0,11228 \\
\hline 38 & 0,21063 & 0,19059 & 0,24034 & 0,18308 & 0,17402 & 0,21288 & 0,10902 & 0,08416 & 0,12484 \\
\hline 39 & 0,23607 & 0,21557 & 0,25720 & 0,20878 & 0,18921 & 0,22905 & 0,12154 & 0,10958 & 0,13801 \\
\hline 40 & 0,25292 & 0,23190 & 0,27466 & 0,22484 & 0,20485 & 0,24568 & 0,13464 & 0,11839 & 0.15176 \\
\hline 41 & 0,27014 & 0,24873 & 0.29211 & 0,24152 & 0,22002 & 0,26273 & 0,14830 & 0,13136 & 0,16608 \\
\hline 42 & 0,28772 & 0,28585 & 0,31011 & 0,26849 & 0,23738 & 0,29018 & 0,16250 & 0,14487 & 0,18094 \\
\hline 43 & 0,30563 & 0,28329 & 0,32844 & 0,27584 & 0,25420 & 0,20801 & 0,17722 & 0,15880 & 0,18632 \\
\hline 44 & 0,32384 & 0,30102 & 0,34708 & 0,28353 & 0,27136 & 0,31619 & 0,10243 & 0,17340 & 0,21221 \\
\hline 45 & 0,34321 & 0,31802 & 0,36600 & 0,31153 & 0,28884 & 0,33469 & 0,20812 & $0,1883 \theta$ & 0,22858 \\
\hline 46 & 0,38103 & 0,33725 & 0,38516 & 0,32983 & 0,30650 & 0,35349 & 0,22428 & 0,20380 & 0,24540 \\
\hline 47 & 0,37706 & 0,35669 & 0.40454 & 0,34839 & 0,32461 & 0.37258 & 0,24082 & 0,21060 & 0,26286 \\
\hline 48 & 0,39008 & 0,37432 & 0,42411 & 0,36718 & 0,34285 & 0,39188 & 0.25778 & 0,23585 & 0,28033 \\
\hline 49 & 0,41835 & 0,39309 & 0,44383 & 0,38618 & 0,36129 & 0,41137 & 0.27511 & 0,25244 & 0,28837 \\
\hline 50 & 0.43775 & 0,41199 & 0,48368 & 0,40535 & 0,37890 & 0,43105 & 0,29278 & 0,26900 & 0.31677 \\
\hline 51 & 0,45724 & 0,43098 & 0,48362 & 0,42466 & 0,39885 & 0,45088 & 0,31078 & 0.28659 & 0,33549 \\
\hline 52 & 0,47680 & 0,45005 & 0,50362 & 0,44410 & 0.41763 & 0,47082 & 0.32008 & 0,30411 & 0,35451 \\
\hline 53 & 0,40640 & 0,46916 & 0.52365 & 0,46361 & 0,43649 & 0,40084 & 0,34761 & 0,32189 & 0,37379 \\
\hline 54 & 0.51600 & 0,48828 & 0,54367 & 0,48319 & 0,45552 & 0,51091 & 0,36630 & 0,33090 & 0,30330 \\
\hline 55 & 0.53557 & 0,50739 & 0.56364 & 0,60279 & 0,47469 & 0.53088 & 0.38538 & 0,35812 & 0,41301 \\
\hline 56 & 0.55509 & 0,52646 & 0.58354 & 0,52238 & 0,42066 & 0,55103 & 0,40455 & 0,37652 & 0,43289 \\
\hline 57 & 0,57453 & 0,54547 & 0,60333 & 0,54184 & 0.61272 & 0,57102 & 0.42386 & 0,30507 & 0,46290 \\
\hline 58 & 0,50385 & 0,56439 & 0,62298 & 0,56144 & 0.53174 & 0,50093 & 0,44328 & 0,41376 & 0,47301 \\
\hline 59 & 0,61303 & 0,58320 & 0,64244 & 0,58084 & 0,55068 & 0,61070 & 0,46280 & 0,43254 & 0,40319 \\
\hline 60 & 0,03203 & 0,60186 & 0,68170 & 0,60012 & 0.56954 & 0,83032 & 0,48237 & 0,46141 & 0,51341 \\
\hline 61 & 0,65083 & 0.62036 & 0,68071 & 0,61024 & 0.58827 & 0,64974 & 0,50197 & 0,47032 & 0,53362 \\
\hline 62 & 0,66040 & 0,83866 & 0,60044 & 0,63818 & 0,60685 & 0,66884 & 0,52157 & 0,48925 & 0,55379 \\
\hline 63 & 0,68771 & 0,85875 & 0,71786 & 0,65891 & 0,62527 & 0,68787 & 0,54113 & 0,50819 & 0,57389 \\
\hline 64 & 0,70573 & 0,67460 & 0,73593 & 0,67640 & 0,64349 & 0,70561 & 0,66063 & 0,62709 & 0,58389 \\
\hline 65 & 0.72343 & 0.69218 & 0.75364 & 0,69362 & 0.66149 & 0,72483 & 0.58004 & 0.545 .94 & 0,61375 \\
\hline 66 & 0,74080 & 0,70947 & 0,77093 & 0.71164 & 0,67925 & 0,74279 & 0,59932 & 0,56471 & 0,63344 \\
\hline 67 & 0,75779 & 0.72646 & 0.78779 & 0,72913 & 0,69673 & 0,76036 & 0,61845 & 0,58337 & 0,65292 \\
\hline 68 & 0,77438 & 0,74311 & 0,80410 & 0,74638 & 0,71393 & 0,77751 & 0,63740 & 0,60191 & 0,67216 \\
\hline 69 & 0,78055 & 0,76940 & 0,82009 & 0,76324 & 0,73081 & 0,79241 & 0,65614 & 0,62028 & 0,09112 \\
\hline 70 & 0,80640 & 0,77460 & 0,83653 & 0,77974 & 0,74681 & 0,81138 & 0,67540 & 0,63852 & 0,71144 \\
\hline 71 & 0,82100 & 0.78951 & 0,85281 & 0,79580 & 0,76205 & 0,82816 & 0,60428 & 0,05034 & 0,73129 \\
\hline 72 & 0,83701 & 0,80403 & 0,86829 & 0,81152 & $0, \pi 710$ & 0,84452 & 0,71261 & 0,67367 & 0,75001 \\
\hline 73 & 0,85177 & 0,81815 & 0.88350 & 0,82679 & 0,79172 & 0,86041 & 0,73033 & 0,68046 & 0,70031 \\
\hline 74 & 0,86584 & 0,83181 & 0,82829 & 0,84149 & 0,80578 & 0,87570 & 0,74760 & 0,70665 & 0,78735 \\
\hline 76 & 0,87968 & 0.84502 & 0,91255 & 0.85570 & 0,81240 & 0.88049 & 0,78425 & 0.72249 & 0.80600 \\
\hline 76 & 0,89291 & 0,85772 & 0.92627 & 0.86940 & 0,83252 & 0,80474 & 0,78059 & 0,73793 & 0,82221 \\
\hline$\pi$ & 0,90560 & 0,86991 & 0,03944 & 0,88256 & 0.84513 & 0.81844 & 0,70648 & 0,75295 & 0,83894 \\
\hline 78 & 0,91771 & 0,88155 & 0,85200 & 0.89515 & 0,85719 & 0.83155 & 0.81187 & 0.76750 & 0,85515 \\
\hline 79 & 0,02922 & 0.89261 & 0.06394 & 0.80715 & 0.86867 & 0.04403 & 0.82872 & 0,78153 & 0.87079 \\
\hline
\end{tabular}

$\because$ Roteréncia para a Tabola 32. 
TABELA XI (ANEXO V)

ANÁLISE DE VARIÂNCIA E PARÂMETROS ESTIMADOS

PARA OS VALORES DA TABELA X: PESSOAS

EDENTULAS.(")

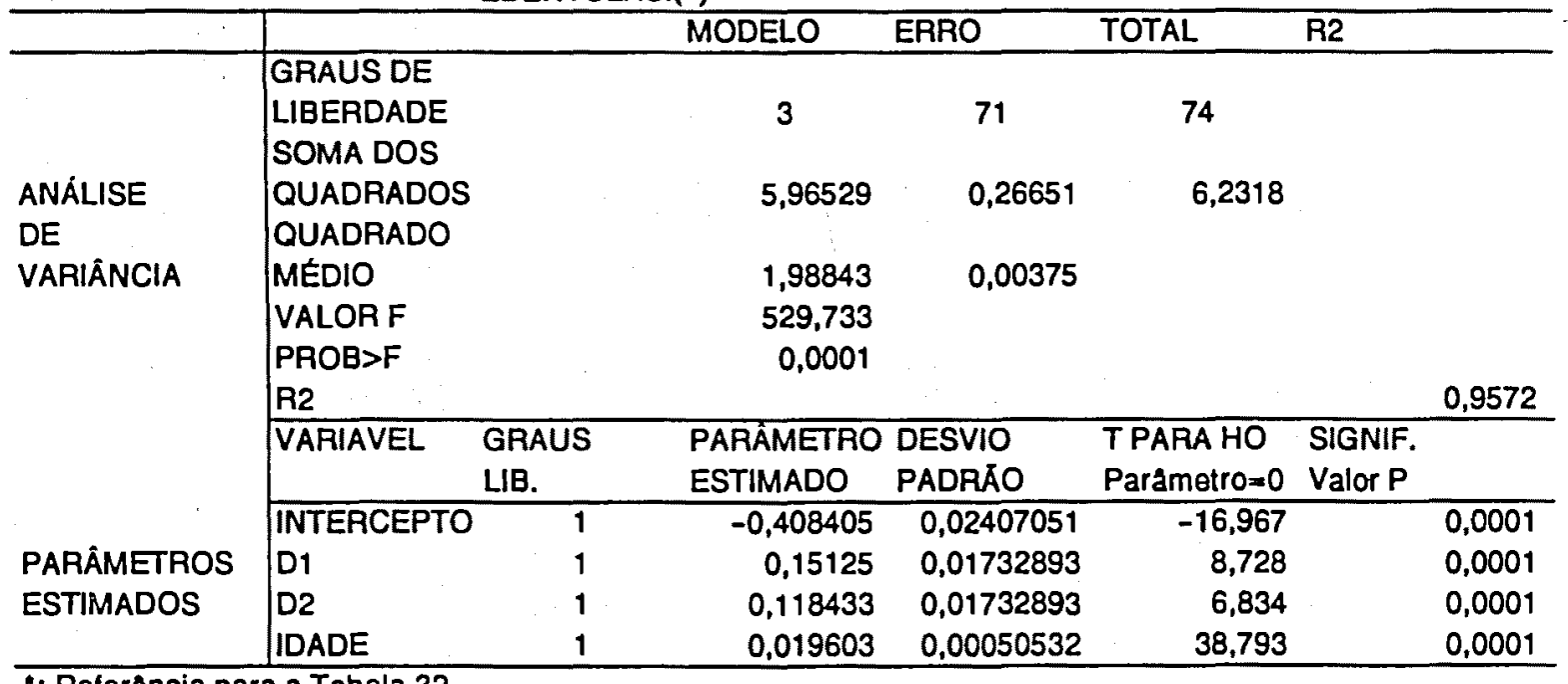

: Referencia para a Tabela 32. 
TABELA XH (ANEXOV)

PERCENTUAL DE PESSOAS SEM DOENGA PERIODONTAL 8EQUNDO LONDE E

PENOA COM OS WTEFNALOS DE CONFWNCA BRAOM, ZONA URBNMA(")

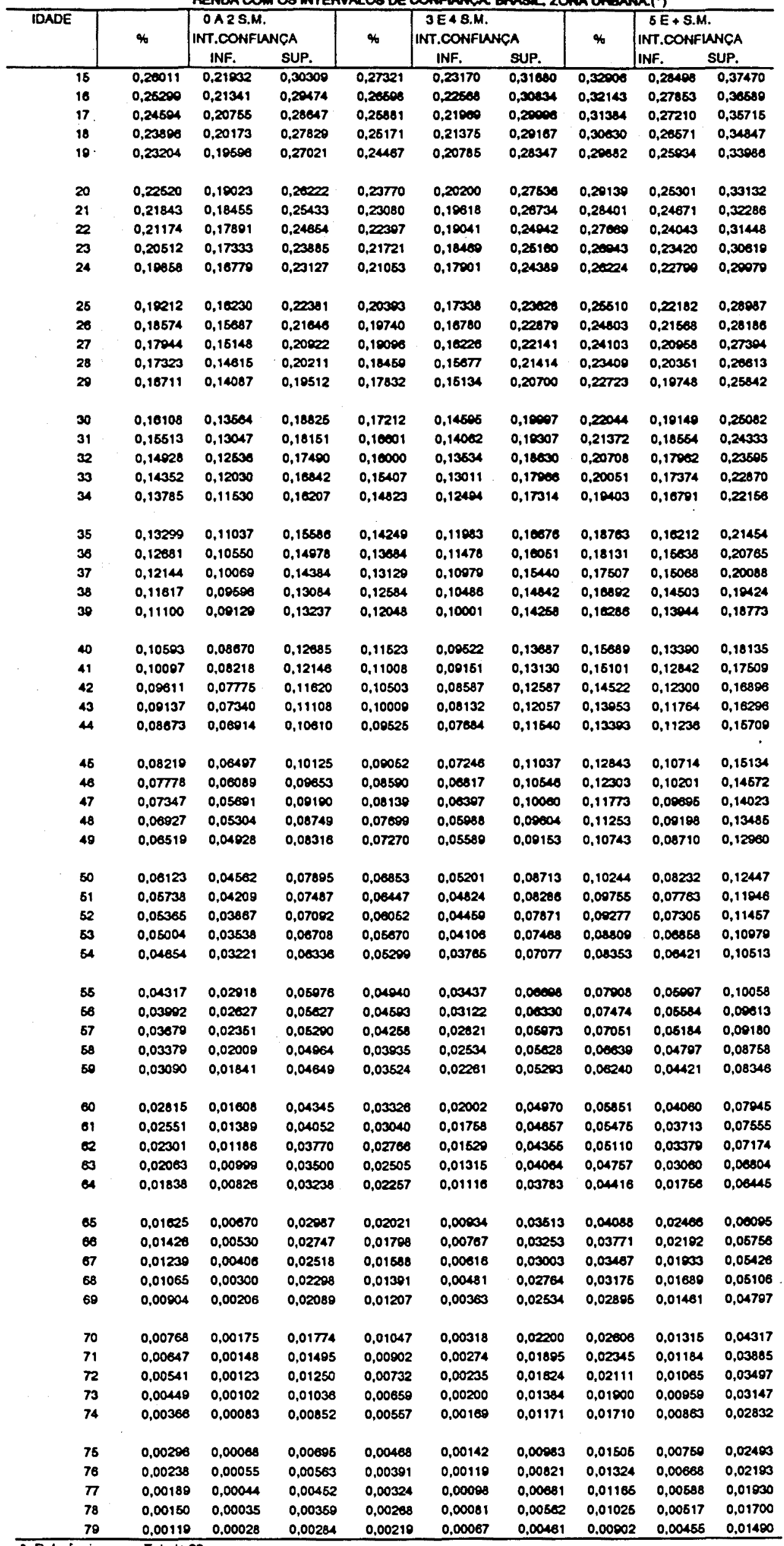


TABELA XIII (ANEXO V)

ANÁLISE DE VARIÂNCIA E PARÂMETROS ESTIMADOS

PARA OS VALORES DA TABELA XII: PESSOAS SEM

DOENCCA PERIODONTAL.(")

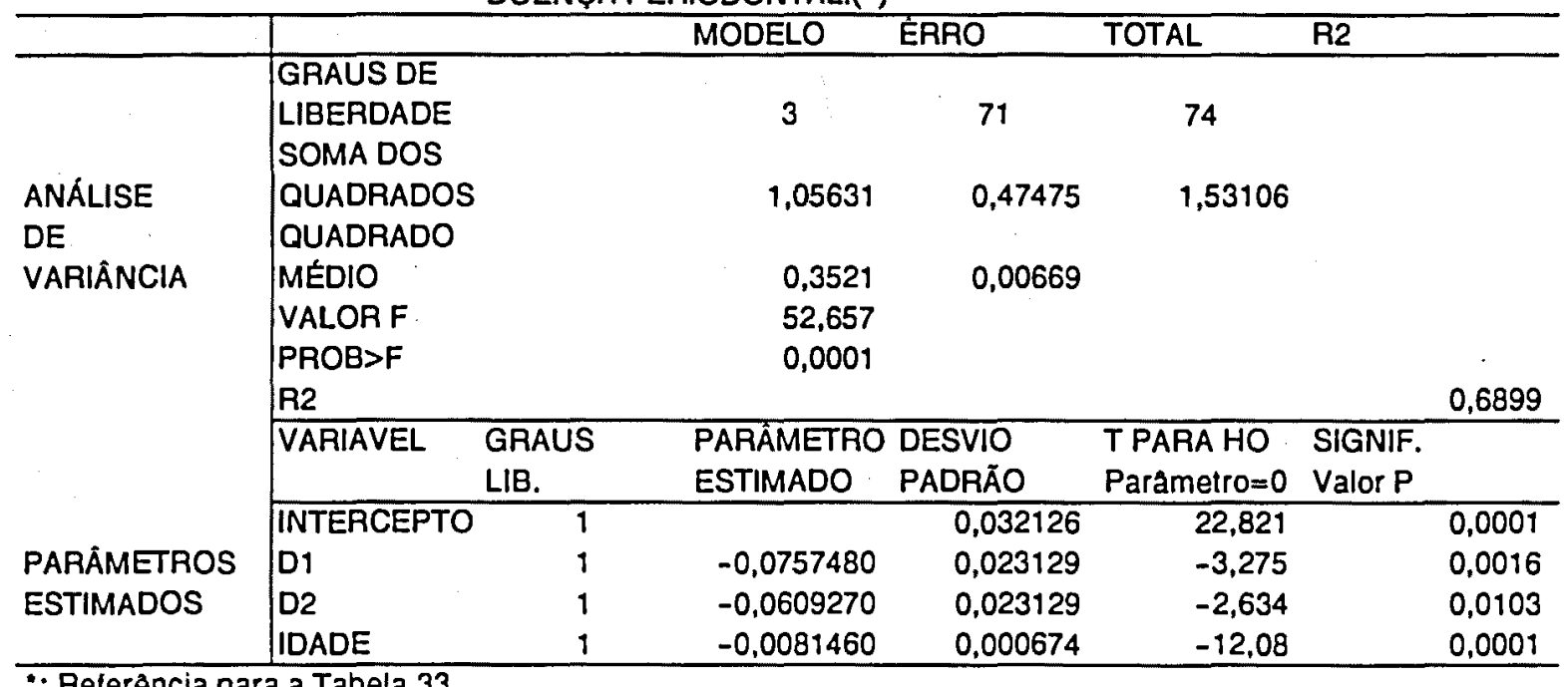

: Referencia para a Tabela 33. 
27 A

\section{A $N E X X O$}

MODELO DE VIGILÂNCIA EPIDEMIOLÓGICA:

RELAÇÃO DE CIDADES DE PORTE MÉDIO E GRANDE QUE COMPÕEM O SEGUNDO ESTRATO 


\section{ANEXO VI}

Estão listadas a seguir todas as cidades que foram incluidas no 22 Estrato do modelo de vigilância epidemiológica sugerido no Título 9.2.6 e constante da Tabela 40 .

A relação está estratificada por Estado e se refere a localidades consideradas como sendo de porte médio ou grande. Este porte varia segundo as características de cada unidade federada, sendo de 25 mil habitantes ou mais no Acre, Amapá, Roraima e Tocantins; de $50 \mathrm{mil}$ ou mais em Minas Gerais, Rio de Janeiro, São Paulo, Paraná e Rio Grande do Sul e de 40 mil ou mais em todas as demais. Vale lembrar que no Estrato 1 estão as capitais e no Estrato 3 todas as outras cidades não especificadas nesta relação, ou seja, as de pequeno porte.

ACRE

Cruzeiro do Sul, Plácido de Castro, Sena Madureira, Tarauacá

AMAZONAS

Coari, Itacoatiara, Manacapurú, Parintins

PARÁ

Abaetetuba, Acará, Alenquer, Altamira, Ananindeua, Bragança, Breves, Cametá, Capanema, Castanhal, Conc. do Araguaia, Curionópolis, Igaraté Mirim, Itaituba, Marabá, Monte Alegre, óbidos, Oriximiná, Paragominas, Porteu, Redenção, Rondon do Pará, Santarém, S.Dom. do Capim, Tomé Açú, Tucuruí, Viseu, Xinguara

\section{RONDÔNIA}

Ariquemes, Cacoal, Jaru, Ji-Paraná, ouro Preto D'oeste, Pimenta Bueno, Rolim de Moura

\section{TOCANTINS}

Araguaina, Araguatins, Colinas de Tocantins, Guarai, Gurupi, Paraiso de Tocantins, Porto Nacional, Tocantinópolis

ALAGOAS

Arapiraca, Atalaia, Coruripe, Palmeira dos Índios, Penedo, Rio Largo, São Miguel dos Campos, União dos Palmares

\section{BAHIA}

Alagoinhas, Araci, Barra, Barreiras, Bom Jesus da Lapa, Brumado, Caetité, Camacan, Camaçari, Camamu, Campo Formoso, Candeias, Casa Nova, Catu, Conceição do Coité, Cruz das Almas, Euclides da Cunha, Eunápolis, Feira de Santana, Guanambi, Ilhéus, Ipiaú, Ipirá, Itaberaba, Itabuna, Itamarajú, Itapetinga, Jacobina, Jequié, Juazeiro, Lauro de Freitas, Monte Santo, Paulo Afonso, Poções, Porto Seguro, Ribeira do Pontal, Riacho do Jacuipe, Santa Maria da Vitória, Santo Amaro, Sto.Antonio de Jesus, Senhor do Bomfim, Serrinha, Sento Sé, Simões Filho, Teixeira de Freitas, Valença, Vitória da Conquista, Xique Xique 


\section{CEARÁ}

Acaraú, Acopiara, Aquiraz, Aracati, Beberibe, Boa Viagem, Camocim, Canindé, Cascavel, Caucaia, Crateús, Crato, Granja, Icó, Iguatú, Juazeiro do Norte, Limoeiro do Norte, Maracanaú, Maranguape, Mombaça, Morada Nova, Nova Russas, Pacatuba, Pedra Branca, Quixadá, Quixeramobim, Russas, sta.Quitéria, Sobral, Tauá, Tianguá, Viçosa do Ceará

\section{MARANHÃO}

Açailândia, Araioses, Barra do Corda, Carutapera, Caxias, Codó, Colinas, Coroatá, Curupuru, Esperantinópolis, Grajaú, Imperatriz, Itapecuru Mirim, João Lisboa, Lago da Pedra, Paço do Lumiar, Parnarama, Pedreiras, Pinheiro, Poção de Pedras, Pres. Dutra, S.José de Ribamar, Sta. Inês, Sta. Luzia, Timon, Turiaçú, Tutóia, Viana, Vitória do Mearim, zé Doca

\section{PARAIBA}

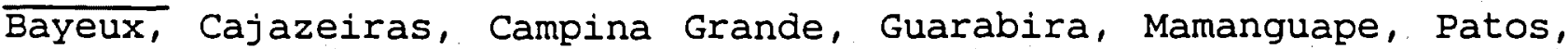
Pombal, Sta. Rita, Sapé, Sousa

\section{PERNAMBUCO}

Abreu e Lima, Águas Belas, Aliança, Araripina, Arco Verde, Belo Jardim, Bezerros, Bom Conselho, Cabo, Camaragibe, Caruaru, Escada, Garanhuns, Goiana, Gravatá, Igarassu, Ipojuca, Jaboatão, Limoeiro, olinda, Palmares, Paudalho, Paulista, Pesqueira, Petrolina, Ribeirão, Salgueiro, S.Lourenço da Mata, S.Bento do Una, Serra Talhada, Surubim, Timbauba, Vitoria do Sto. Antão

PIAUI

Barras, Campo Maior, Floriano, Luizilândia, Oeiras, Parnaiba, Paulistana, Pedro II, Piripiri, S.João do Piaui, S.Raimundo Nonato, União

RIO GRANDE DO NORTE

Açú, Caicó, Ceará Mirim, Currais Novos, Mossoró, São Gonçalo do Amarante

SERGIPE

Estância, Itabaiana, Lagarto, São Cristóvão

ESPIRITO SANTO

Afonso Cláudio, Aracruz, Cachoeiro do Itapemirim, Cáriacica, Colatina, Guarapari, Itapemirim,.. Linhares, Nova Venécia, São Gabriel do Palha, São Mateus, Serra, Vila Velha

\section{MINAS GERAIS}

Araguari, Araxá, Barbacena, Betim, Bocaiúva, Caratinga, Cataguases, Cons. Lafaiete, Contagem, Cel. Fabriciano, Curvelo, Divinópolis, Formiga, Gov. valadares, Ibirité, Ipatinga, Itabira, Itajubá, Itaúna, Ituiutaba, Iturama, Janaúba, Januária, João Monlevade, Juiz de Fora, Lavras, Manhuaçú, Montes Claros, Muriaé, Nova Lima, Ouro Preto, Paracatú, Pará de Minas, Passos, Patos de Minas, Patrocínio, Poços de Caldas, Ponte Nova, Pouso Alegre, Ribeirão das Neves, Rio Pardo de Minas, Sabará, Salinas, Santa Luzia, São Francisco, São 
João del. Rei, Sete Lagoas, Teófilo otoni, Timóteo, Três Corações, Ubá, Uberaba, Uberlândia, Unaí, Varginha

\section{RIO DE JANEIRO}

Angra dos Reis, Araruama, Barra do Piraí, Barra Mansa, Cabo frio, Campos dos Goytacases, Duque de Caxias, Itaboraí, Itagauaí, Itaperuna, Macaé, Magé, Nilópolis, Niterói, Nova Friburgo, Nova Iguaçú, Petrópolis, Resende, São Gonçalo, S.João da barra, S.João do Meriti, Teresópolis, Três Rios, Valença, Volta Redonda

\section{SÃO PAULO}

Americana, Amparo, Araçatuba, Araraquara, Araras, Assis, Atibaia, Avaré, Barretos, Barueri, Baurú, Bebedouro, Birigui, Botucatú, Bragança Paulista, Caçapava, Campinas, Capão Bonito, Carapicuiba, Catanduva, Cotia, Cruzeiro, Cubatāo, Diadema, Embú, Fernandópolis, Ferraz de Vasconcelos, Franca, Franco da Rocha, Guaratinguetá, Guarujá, Guarulhos, Indaiatuba, Itapecerica da Serra, Itapetininga, Itapeva, Itapevi, Itapira, Itaquaquecetuba, Itatiba, Itú, Jaboticabal, Jacareí, Jandira, Jaú, Jundiaí, Leme, Limeira, Lins, Lorena, Marília, Matão, Mauá, Mococa, Mogi das Cruzes, Mogi Guaçú, Mogi Mirim, Osasco, Ourinhos, Piedade, Pindamonhangaba, Piracicaba, Pirassununga, Poá, Praia Grande, Pres.Prudente, Registro, Ribeirão Pires, Rio Preto, Rio Claro, Salto, Sta. Bárbara D'Oeste, Santo André, Santos, S.Bernardo do Campo, S.Caetano do Sul, S.Carlos, S.João da Boa Vista, S.José do Rio Preto, S.José dos Campos, São Roque, São Vicente, Sertãozinho, Sorocaba, Sumaré, Susano, Taboão da Serra, Taquaritinga, Tatuí, Taubaté, Tupã, Valinhos, Votorantim, Votuporanga

\section{PARANÁ}

Apucarana, Arapongas, Cambé, Campo Largo, Campo Mourão, Cascavel, Castro, Colombo, Dois Vizinhos, Foz do Iguaçú, Francisco Beltrão, Guaratuba, Irati, Ivaiporã, Londrina, Mal. Cândido Rondon, Maringá, Ortigueira, Paranaguá, Paranavaí, Pato Branco, Piraquara, Pitanga, Ponta Grossa, Prudentópolis, S.José dos Pinhais, Telêmaco Borba, Toledo, Umuarama

\section{RIO GRANDE DO SUL}

Alegrete, Alvorada, Bagé, Bento Gonçalves, Cachoeira do Sul, Cachoeirinha, Camaquã, Canoas, Carazinho, Caxias do Sul, Cruz Alta, Erechim, Esteio, Gravataí, Guaiba, Ijuí, Lajeado, Novo Hamburgo, Palmeira das Missões, Passo Fundo, Pelotas, Rio Grande, Santa Cruz do Sul, Santa Maria, Santana do Livramento, Santa Rosa, Santiago, Santo Ângelo, São Borja, São Gabriel, São Leopoldo, São Luiz Gonzaga, Sapucaia do Sul, Três Passos, Uruguaiana, Vacaria, Venâncio Aires, Viamão

\section{SANTA CATARINA}

Araranguá, Blumenau, Brusque, Caçador, Campos Novos, Canoinhas, Chapecó, Concórdia, Criciuma, Curitibanos, Itajaí, Jaraguá do sul, Joinville, Laguna, Lages, Mafra, Palhoça, Rio do Sul, são Bento do Sul, São José, São Miguel D'Oeste, Tubarão 
GOIÁS

Anápolis, Aparecida de Goiânia, Catalão, Formosa, Itumbiara, Jataí, Luziânia, Niquelândia, Porangatú, Rio Verde, Trindade

MATO GROSSO DO SUL

Aquidauana, Corumbá, Coxim, Dourados, Mundo Novo, Paranaiba, Ponta Porã, Três lagoas

MATO GROSSO

Alta Floresta, Barra do Garças, Cáceres, Rondonópolis, Tangará da serra, Várzea Grande 